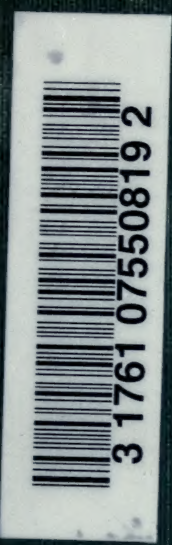




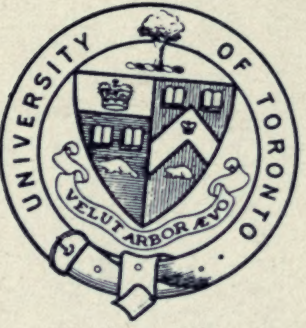

Presented to the

UNIVERSITY OF TORONTO LIBRARY

by the

ONTARIO LEGISLATIVE

LIBRARY

1980 




\section{BRITISH FORESTRY}

ITS PRESENT POSITION AND OUTLOOK AFTER THE WAR 




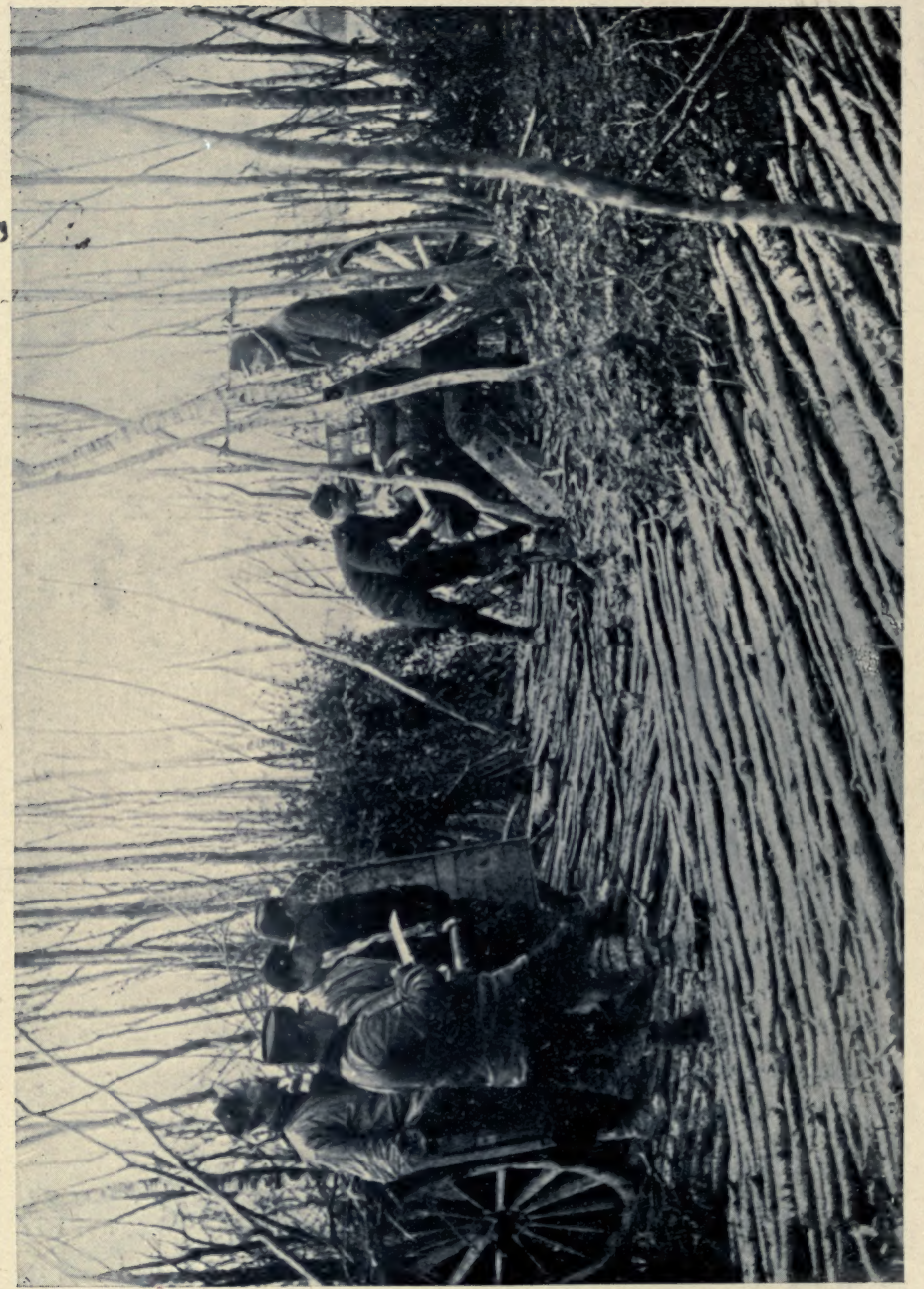

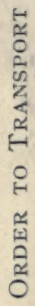

Z $\stackrel{0}{A}$

o

z

- 9

近

4) 은

'

02

$>0$

능 비 리

$\mathrm{H}$

응 뜬

a 0

i

$\simeq$ Z

40

ए

달

돈

2

告 


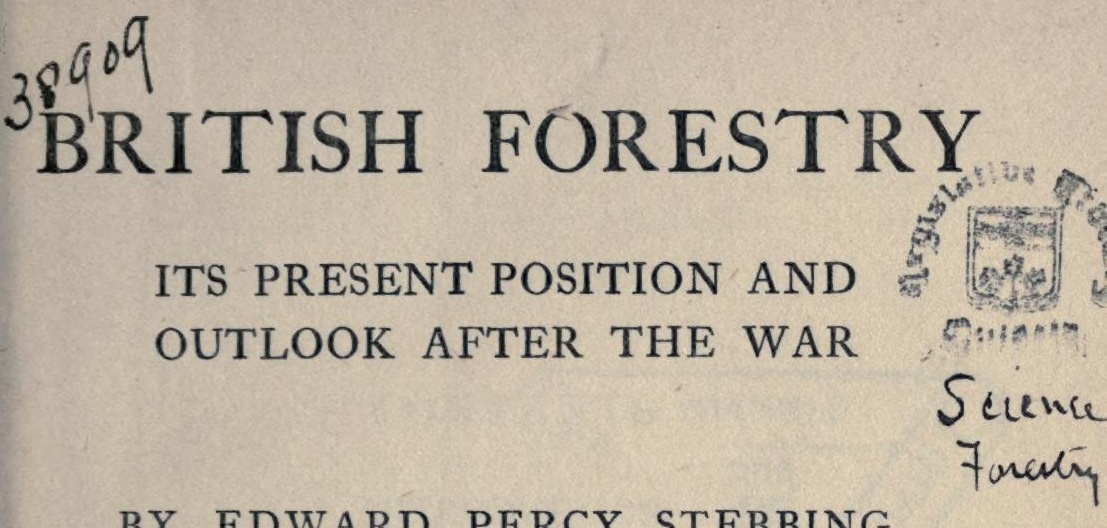

BY EDWARD PERCY STEBBING

HEAD OF THE FORESTRY DEPARTMENT, UNIVERSITY OF EDINBURGH

WITH ILLUSTRATIONS

LONDON

JOHN MURRAY, ALBEMARLE STREET, W.

I 916 


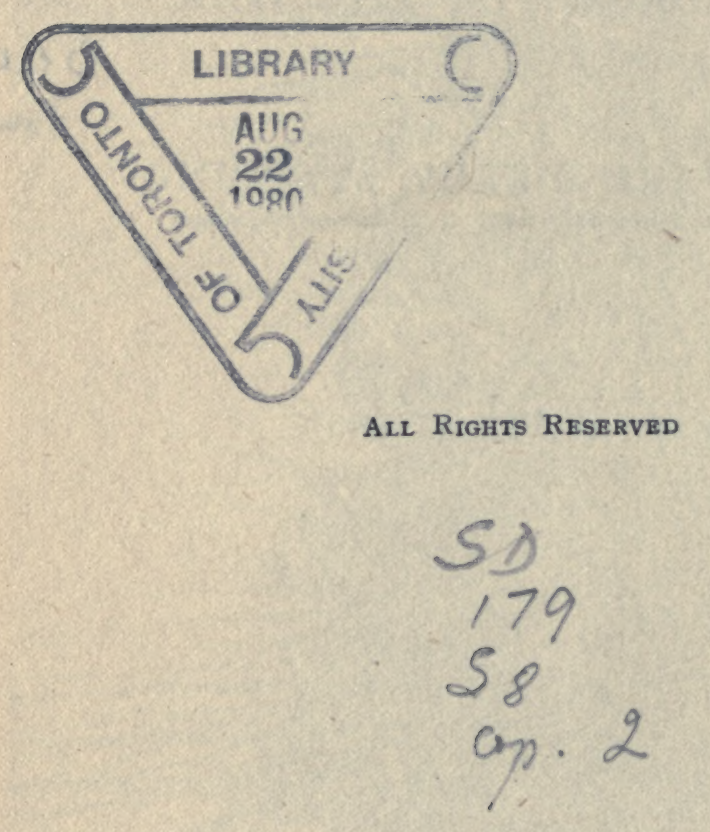




\section{CONTENTS}

\section{INTRODUCTION}

EVELYN'S “ SYLVA" AND PRESENT TIMES • . ix

\section{PART I}

A NATIONAL PLANTING SCHEME

ARTICLE

I. FORESTRY : WHAT IT MEANS TO THE NATION I

II. THE POSITION OF THE AFFORESTATION QUESTION IN THIS COUNTRY AT THE OUTBREAK OF THE WAR-AND NOW . I3

III. A NAtional PLANTING SChEME • • 27

IV. FINANCE AND PLANTING METHODS • 37

V. AFFORESTATION AND LABOUR . • 50

\section{PART II}

BRITISH TIMBER SUPPLIES AND THE FORESTS OF RUSSIA

VI. TIMBER SUPPLIES AND FAMINE PRICES - 55

VII. BRITISH TIMBER SUPPLIES AND RUSSIAN FORESTS

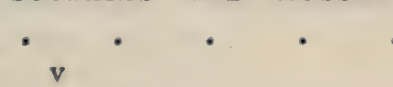

67 
VIII. THE FORESTS OF RUSSIA IN EUROPE

IX. THE FORESTS OF FINLAND AND EUROPEAN

$$
\text { TIMBER SUPPLIES • . . . . } \quad \text { IO4 }
$$

X. THE FORESTS OF SIBERIA AND TURKESTAN . I3O

XI. THE CEDAR (CEMBRAN PINE) TRADE OF ASIATIC RUSSIA

\section{PART III}

\section{TIMBER SUPPLIES AND THE WAR}

XII. TIMBER SUPPLIES AND THE WAR-IMPORTS IN IgI3 * * . . . . I6O

XIII. EFFECT OF SIX MONTHS' WAR ON THE TIMBER

SUPPLIES . . . . . I II

XIV. TIMBER IMPORTS AND EXPORTS IN I9I5 • 202

\section{PART IV}

THE EMPLOYMENT OF WOMEN IN FORESTRY

XV. WOMEN AND FORESTRY • • • . 215

XVI. THE EMPLOYMENT OF WOMEN IN FORESTRY

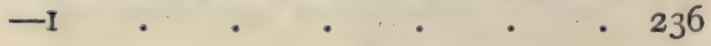

XVII. THE EMPLOYMENT OF WOMEN IN FORESTRY

-II . . . . . . 247 


\section{LIST OF PLATES}

FRENCH ENGINEERS MAKING A ROAD OUT OF YOUNG SAPLINGS IN ORDER TO TRANSPORT HEAVY GUNS OVER THE RAIN-SOAKED FIELDS • • Frontispiece

Reproduced by courtesy of the "Topical" Press Agency.

FACNV PAGE

PLATE I. SCOTS PINE, STRATHORD. LARCH, CRAIG VIVIAN, PERTHSHIRE • • . . 6

PLATE 2. A FELLED AREA AND NEWLY PLANTED AREA, PEEBLESSHIRE • . . . . 8

PLATE 3. SCOTS PINE, BALUAN, BLAIR ATHOLI • • I6

PLATE 4. THIRLMERE, LAKE DISTRICT. TALLA CATCHMENT AREA, PEEBLESSHIRE . . . 22

PLAte 5. PLANTING IN A PEEblesshire GLEN • $\quad 28$

PLATE 6. "HYBRID" LARCH, MURTHLY. JAPANESE LARCH, BLAIR ATHOLI, PERTHSHIRE • 34

PLATE 7. OLD LARCH WOOD, MUCH UNDERSTOCKED, PEEBlesshire $\quad \cdot \quad \cdot \quad \cdot \quad \cdot \quad \cdot \quad \cdot 39$

PLATE 8. FELLING OAK COPPICE SCRUB FOR PIT PROPS, HERMITAGE WOODS, DUNKELD. LOADING TRUCKS WITH PITWOOD AT A TEMPORARY SIDING ON THE HIGHLAND LINE . . 40

PLATE 9. OAK NATURAL REGENERATION IN THE QUEEN'S WOOD, FRITH PARK, SURREY . • vii 
viii LIST OF PLATES

FACRNG PAGR

PLATE 1O. PIT PLANTING AND MATTOCK PLANTING . 48

PLATE II. LARCH INTERPLANTED WITH DOUGLAS, MURTHLY. LARCH UNDERPLANTED WITH DOUGLAS, NOVAR, ROSS-SHIRE • . 52

PLATE 12. LADYWELL FOREST NURSERY, DUNKELD, PERTHSHIRE * * * * * 228 


\section{INTRODUCTION}

\section{EVELYN'S " SYLVA" AND PRESENT TIMES}

To those who love the beautiful woods of this country or, in fact, any of the open-air pursuits connected with them, Evelyn's classic Sylva will be well known. There is a fascination and at the present time a grave significance for us all in the quaint wording of its title" Sylva, or a Discourse of Forest Trees and the Propagation of Timber in His Majesty's Dominions."

Perhaps never since it made its first appearance has the need for pondering over and acting upon the advice of this most remarkable and far-seeing man, as adumbrated in his Sylva, been so urgent as in these early years of the twentieth century.

The Sylva was written at the instigation and under the auspices of the Royal Society, then recently founded under the patronage of Charles the Second (in I662, Evelyn being one of the first Fellows and a Member of the Council). Evelyn is interesting on the objects for which the great Society was inaugurated: "Those who perfectly comprehend the scope and end of that Noble Institution, which is to improve natural knowledge, and enlarge the empire of operative philosophy, not by an abolition of the old, but by the real effects of the experimental, collecting, examining, and im- 


\section{$x$ EVELYN'S "SYLVA" AND PRESENT TIMES}

proving theirscattered phenomena, with a view to establish even the received methods and principles of the schools, as far as were consistent with truth and matter of fact, thought it long enough that the world had been imposed upon by that national and formal way of delivering divers systems and bodies of philosophy, falsely so-called, beyond which there was no more country to discover; which being brought to the test and trial, vapours all away in fume and empty sound."

Amongst the first of the activities of the Society was the direct encouragement, through the publication of the Sylva, given to planting, then an urgent need of the day for the sake of the Navy. In confirmation of the Society's interest in this matter we read in the opening paragraphs of the Preface to the Reader (4th ed.):

"After what the Frontispiece and Porch of this Wooden Edifice presents you, I shall need no farther to repeat the occasion of this following discourse; I am only to acquaint you, That as it was delivered to the Royal Society (on the fifteenth day of October I662) by an unworthy Member thereof, in obedience to their commands; by the same it is now republished without any farther prospect: And the reader is to know, that if these dry sticks afford him any sap, it is one of the least and meanest of those pieces which are every day produced by that illustrious assembly, and which enrich their collections, as so many monuments of their accurate experiments, and public endeavours, in order to the production of real and useful theories, the propagation and improvement of natural science, and the honour of their institution." 
As evidence of the King's interest in planting, even when allowance is made for the laudatory language of the age (and Evelyn was no mean courtier), the opening paragraphs of the author's " Dedication to the King's Most Sacred Majesty," 4th edition, dated December 5, 1678 , is as worthy of remembrance now as it is important historically :

"For to whom, Sir, with so just and equal right should I present the fruits of my labours, as to the Patron of that Society, under whose influence it was produced, so to whose auspices alone it owes the favourable acceptance which it has received in the world? To You, then, Royal Sir, does this Fourth Edition continue its humble addresses, tanquam Nemorum $V$ indici, as of old, they paid their devotions Herculi

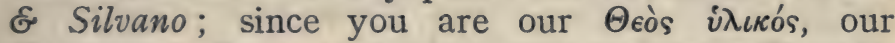
Nemorensis Rex; as having once had your Temple, and Court too, under that sacred Oak which You consecrated with your presence, and we celebrate, with just acknowledgment to God, for Your Preservation. I need not acquaint your Majesty how many millions of timber-trees, besides infinite others, have been progagated and planted throughout your vast dominions, at the institution, and by the sole direction of this work; because your gracious Majesty has been pleased to own it publicly for my encouragement, who, in all that I here pretend to say, deliver only those precepts which your Majesty has put into practice ; as having, like another Cyrus, by your own royal example, exceeded all your predecessors in the plantations you have made, beyond, I dare assert it, all the Monarchs of this Nation, since the conquest of it. And, indeed, what more august, what more worthy your Majesty, or more becoming our imitation, than, whilst You are thus solicitous for the public good, we 
pursue your Majesty's great example, and, by cultivating our decaying woods, contribute to your power, as to our great wealth and safety ; since whilst your Majesty is furnished to send forth those Argos and Trojan hordes, about this happy island, we are to fear nothing from without it ; and whilst we remain obedient to your just commands, nothing from within it."

It makes delightful reading and withal carries a moral. That the Royal Society, from its initiation, thus had the true welfare of the nation at heart in publishing the Sylva is borne out by certain remarks in the preface to the 6 th edition, written by its editor, Dr. A. Hunter, F.R.S., over a hundred years later (August 1776). When contrasted with the above-quoted extracts from Evelyn's Dedication they merit our earnest consideration :

"Soon after the publication of the Sylva, which appeared in I664," writes Dr. Hunter, " the Spirit for Planting increased to a high degree; and there is reason to believe that many of our ships which, in the last war, gave laws to the whole world, were constructed from oaks planted at that time. The present age must reflect upon this with gratitude; and it is to be hoped that we shall be ambitious to receive from posterity the same acknowledgments that we, at this moment, pay to the memory of our virtuous Ancestors."

The results of the action of the Royal Society in the early days of the reign of Charles the Second, and of the industry and knowledge of their great Fellow, were to witness even more glorious achievements by the "wooden walls" which their foresight enabled 
the nation to build. For the planting which was the outcome, the direct outcome, of the publication of the Sylva safeguarded the nation from invasion by Napoleon, enabled Trafalgar to be fought and won, and thus gave us security from invasion for a whole century thereafter.

The "wooden walls" have disappeared and steel ones have taken their place, but the need for planting is at the present time just as urgent as it was in Evelyn's day. The timber and other materials are put to different uses but they are required in far larger amounts and for a far greater variety of purposes. Unfortunately our ancestors of the time of Dr. Hunter and subsequently did not follow the advice of the Sylva's great author, and we are suffering accordingly.

There was, it is true, a certain revival of planting in the latter half of the eighteenth and the early part of the nineteenth centuries. Before Hunter issued his edition of the Sylva the Royal Society of Arts had given attention to the question. Founded in I754, the Society soon afterwards instituted a system of premiums and medals to be awarded to those sowing and planting up the greatest areas of land. Between I758 and I821, I27 gold and 40 silver medals were awarded in this way, in addition to pecuniary premiums. As a result of this enlightened policy a considerable amount of planting was carried out during this period.

After about 1820 planting, save in a few exceptional cases, appears to have gradually ceased to be a hobby of the landowner or to be considered as exercising any importance in the national economy of the nation. 
Let us accompany Evelyn for a short space in some of his reasons for writing the Sylva. It must be confessed that he is apt to ramble a little, but his rambling is altogether delightful. And it is all so entirely $a$ propos to our present needs in this direction. Evelyn is giving his reasons to the reader :

" If to this there be anything subjoined here, which may a while bespeak the patience of the reader, it is only for the encouragement of an industry, and worthy labour, much in our days neglected, as haply reputed a consideration of too sordid and vulgar a nature for Noble Persons and Gentlemen to busy themselves withal, and who oftener find out occasions to fell down and destroy their woods and plantations, than either to repair or improve them.

"But we are not without hopes of taking off these prejudices, and of reconciling them to a subject and an industry which has been consecrated, as I may say, by as good and as great persons as any the world has produced; and whose names we find mingled amongst Kings and Philosophers, grave Senators and Patriots of their country ; for such of old were Solomon, Cyrus and Numa, Licinius, surnamed Stolo, Cato, and Cincinnatus; the Pisos, Fabii, Cicero, the Plinys, and thousands more whom I might enumerate, that disdained not to cultivate these rusticities even with their own hands, and to esteem it no small accession to dignify their titles, and adorn their purple with these rural characters of their affections to planting, and love of this part of Agriculture, which has transmitted to us their venerable names through so many ages and vicissitudes of the world.

"That famous answer alone which the Persian Monarch gave to Lysander, will sufficiently justify that which I have said, besides what we might add out 
of the writings and examples of the rest: But since these may suffice, after due reproofs of the late impolitic waste and universal sloth amongst us, we should now turn our indignation into prayers, and address ourselves to our better-natured countrymen, that such woods, as do yet remain entire, might be carefully preserved, and such as are destroyed, sedulously repaired: It is what all persons who are owners of land may contribute to, and with infinite delight, as well as profit, who are touched with that laudable ambition of imitating their illustrious ancestors, and of worthily serving their generation. To these my earnest and humble advice should be, That at their very first coming to their Estates, and as soon as they get children, they should seriously think of this work of propagation also ; for I observe there is no part of husbandry which men more commonly fail in, neglect, and have cause to repent of, than that they did not begin planting betimes, without which they can expect neither fruit, ornament, or delight, for their labours. Men seldom plant trees till they begin to be wise, that is, till they grow old, and find, by experience, the prudence and necessity of it. When Ulysses, after a ten years' absence, was returned from Troy, and coming home, found his aged father in the field planting of trees, he asked him, 'Why, being now so far advanced in years, he would put himself to the fatigue and labour of planting that, of which he was never likely to enjoy the fruits ?' The good old man, taking him for a stranger, gently replied: 'I plant against my son, Ulysses comes home.' The application is obvious and instructive for both old and young."

It is curious how public duties and necessities repeat themselves throughout the centuries. For surely there never was a period in our history when the 
need for planting was more urgent than it is at the present time! Evelyn continues:

"My next advice is, that they do not easily commit themselves to the dictates of their ignorant hinds and servants, who are, generally speaking, more fit to learn than instruct. "Male agitur cum Domino quem Villicus docet' was an observation of old Cato's ; and it was Ischomachus who told Socrates, discoursing one day upon a like subject, 'that it was far easier to make than to find a good husbandman': I have often proved it so in gardeners, and I believe it will hold in most of our country employments. Country people universally know that all trees consist of roots, stems, boughs, leaves, etc., but can give no account of the species, virtues or farther culture, besides the making of a pit or hole, casting and treading in the earth, etc., which require a deeper search than they are capable of ; we are then to exact labour, not conduct and reason, from the greatest part of them; and the business of planting is an Art or Science (for so Varro has solemnly defined it) and very different from what many in his time accounted of it ; 'Facillimam esse nec ullius acuminis Rusticationem,' namely, That it was an easy and insipid study. It was the Simple Culture only, with so much difficulty retrieved from the late confusion of an intestine and bloody war, like that of ours, and now put in reputation again, which made the Noble Poet write :

\section{Verbis ea vincere magnum}

Quam fit, \& angistis hunc addere rebus honorem!

"Seeing, as the Orator does himself express it, 'Nihil est homine libero dignius,' there is nothing more becoming and worthy of a Gentleman, no, not the 
majesty of a Consul. In ancient and best times, men were not honoured and esteemed for the only learned who were great linguists, profound critics, readers and devourers of books, but such whose studies consisted of the discourses, documents, and observations of their forefathers, ancient and venerable persons, who (as the excellent author of the rites of the Israelites, chap. $\mathrm{XV}$., acquaints us) were not only obliged to instruct and inform their children of the wonderful things God had done for their ancestors, together with the precepts of the Moral Law, Feasts, and Religious ceremonies, but taught them likewise all that concerned Agriculture, joined with lessons of perpetual practice, in which they were, doubtless, exceedingly knowing, whilst, during so many ages, they employed themselves almost continually in it: And though nowadays this noble art be for the most part left to be exercised amongst us by people of grosser and unthinking souls, yet there is no science whatever which contains a vaster compass of knowledge, infinitely more useful and beneficial to mankind, than the fruitless and empty notions of the greatest part of speculatists, counted to be the only erudite and learned men. An Israelite, who, from tradition of his forefathers, his own experience, and some modern reading, had informed himself of the religion and laws which were to regulate his life, and knew how to procure things necessary; who perfectly understood the several qualities of the earth, plants, and places agreeable to each sort, and to cultivate, propagate, defend them from accidents, and bring them to maturity; that also was skilled in the nature of cattle, their food, diseases, remedies, etc., (which those who amongst us pass for the most learned and accomplished Gentlemen and Scholars, are, for the most part, grossly ignorant of, and look upon as base, rustic, and things below them) 
is, in this learned author's opinion, infinitely more to be valued than a man brought up either in wrangling at the Bar, or the noisy and ridiculous disputes of our schools, etc. To this sense the learned Modena. And it is remarkable, that after all that Wise Solomon had said, ' that all was vanity and vexation of spirit,' among so many particulars he reckons up, he should be altogether silent, and say nothing concerning Husbandry; as, doubtless, considering it the most useful, innocent, and laudable employment of our life, requiring those, who cultivate the ground, to live in the country, remote from city-luxury, and the temptation to the vices he condemns."

Thus Evelyn, to the "Noble Persons and Gentlemen," as he styles them, of his time.

That he aroused the interest he set himself to capture, the successful results, recorded by Dr. Hunter a century later, amply show. Their descendants, however, strayed lamentably from the path so ably indicated by Evelyn.

Nations have changed since the Sylva was written. The responsibility of maintaining a proper proportion of woods, managed on commercial lines, commensurate with the requirements of the population can no longer be entirely placed upon the shoulders of private proprietors. It has become the State's business, but the nation as a whole is responsible that the State fulfils this obligation, a most solemn obligation, to its posterity.

A hundred years of security from the danger of invasion. With a few brilliant exceptions, a total lack of interest, on the part of the State and proprietor alike, in planting, or the maintenance in the country 
of that amount of timber which a sudden emergency might demand. An almost total reliance on imports of foreign produce, which our Navy was to undertake to see reached us; for so ran our justification for the neglect of planting, in forgetfulness of the fact that our main sources of supply might become closed, from causes over which the Navy had no control. This was the position when the greatest war in history burst upon us. We were caught totally unprepared and the results, from a financial point of view, were deplorable. Prices mounted up to famine rates. The Admiralty, just as in the days of peril which arose a hundred years after Evelyn lived and died, though now for a different purpose, wanted wood. The War Office wanted timber, large amounts of it. During the first twenty-two months of the war the materials have been obtained at the cost of millions of money. What would Evelyn have said to ash at $3 s$. to $4 s$. per cubic foot, its pre-war price of our day being Is. $6 d$. ?

There appears small reason to doubt that the action of the Royal Society in I662, and of their chosen representative, saved the country a hundred years or so later ; since sufficient oak timber was forthcoming to build the "wooden walls" which gave us the command of the sea.

No one can look into the future, but the present war has shown us the imperative duty which is laid upon each generation to see that sufficient planting is done in its time to ensure that the country shall possess a sufficiency of timber in its hour of need. The war did not find us so prepared. We are now faced with a position similar to that existing at the beginning of 
the reign of Charles the Second, so far as the urgent need of planting is concerned.

The interest aroused in the Royal Society of that day was caused " upon occasion of certain Quæries propounded to that illustrious assembly by the Honourable, the Principal Officers and Commissioners of the Navy," as the title page of the Sylva has it.

Evelyn emphasises this in his introduction:

"Since there is nothing," he says, "which seems more fatally to threaten a weakening, if not a dissolution, of the strength of this famous and flourishing nation, than the sensible and notorious decay of her ' wooden walls' when, either through time, negligence, or other accident, the present Navy shall be worn out and impaired; it has been a very worthy and seasonable advertisement in the honourable and principal Officers and Commissioners, what they have lately suggested to this illustrious Society for the timely prevention and redress of this intolerable defect. For it has not been the late increase of shipping alone, the multiplication of glass-works, iron-furnaces, and the like, from whence this impolitic diminution of our timber has proceeded; but from the disproportionate spreading of tillage, caused through the prodigious havoc made by such as lately professing themselves against root and branch (either to be reimbursed their holy purchases, or for some other sordid respect) were tempted not only to fell and cut down, but utterly to extirpate, demolish and raze, as it were, all those many goodly woods and forests, which our more prudent ancestors left standing for the ornament and service of their country. And this devastation has now become so epidemical, that unless some favourable expedient offer itself, and a way be seriously and 
speedily resolved upon, for a future store, one of the most glorious and considerable bulwarks of this nation, will, within a short time, be totally wanting to it."

Immediate and speedy planting was the chief note of Evelyn's bugle call. He was not concerned with planting schemes to cover a period of fifty years or more. His writings and personal exhortations to his friends and others produced the desired result; and lucky was it for this country that they did so, for the results of that crusade are incalculable.

Dr. Hunter, in his "Notes" to the I776 Edition, briefly accounts for the state of the woods as described by Evelyn. The first attack, of any material consequences, on the woods of the country was begun in the twenty-seventh year of the reign of Henry VIII, when that monarch seized upon the church lands and converted them, together with their woods, to his own use. As the whole kingdom was at that time plentifully stocked with all kinds of timber-trees, especially oak, the fellings then made did not seriously imperil the national timber supply. The deplorable fellings and waste took place during the Civil War, from I642 onwards up to the Restoration. Extensive forests, existing at the commencement of this period, were literally wiped from the face of the country, and have since been only represented by the name attached to them at the time they existed. Both royal and privately owned forests suffered almost equally. It was to remedy this state of affairs that Evelyn wrote. And a hundred years later Dr. Hunter's aim in bringing out a new edition of Evelyn sought to 
arouse once again the "Spirit of Planting." The following extract from his "Notes," penned I40 years ago, might almost have been written for the present time :

" The wants of the nation call for this supply. How many thousand acres of waste land are there in this kingdom, that at this present time produce nothing, but may be profitably improved by planting! Did men of large possessions but rightly consider this, they would carefully look over their estates, search out every useless bog, and plant it with poplars and other aquatics. They would examine all the waste grounds and set apart some for the cottagers, and apply the most barren and useless for plantations. Was such a generous spirit to prevail, we should hear few persons complaining that their ancient common rights are invaded, and that their extreme necessities have obliged them to emigrate to countries far less hospitable than their own.

That Evelyn had commercial forestry in view, in the interests of the national welfare, and not merely the formation of plantations for sporting or amenity purposes, is evidenced by the following remarks on the subject of obtaining the new woods:

"To attend now a spontaneous supply" (i.e. from natural regeneration) "of these decayed materials (which is the vulgar and natural "-and, he might have added, the cheapest- " way) would cost (besides the inclosure) some entire ages repose of the plow, though bread doth indeed require our first care: therefore the most expeditious and obvious method would doubtless be one of these two ways, sowing or planting. 
But, first, it will be requisite to agree upon the species : as what trees are likely to be of greatest use, and the fittest to be cultivated; and then, to consider of the manner how it may be best effected. Truly, the waste and destruction of our woods has been so universal, that I conceive nothing less than an universal plantation of all sorts of trees will supply, and will encounter the defect; and therefore I shall here adventure to speak something in general of them all; though I chiefly insist upon the propagation of such only as seem to be the most wanting and serviceable to the end proposed."

He aptly quotes Virgil, Georgics, II, in his plea for confining himself to useful, i.e. commercial species:

Sed neque quam multæ species, nec nomina quæ sint,

Est numerus; neque enim numero comprendere refert :

Quem qui scire velit, Lybici velit æquoris idem

Discere, quam multæ Zephyro turbentur arenæ.

Evelyn is such a charming companion that it is difficult to refrain from accompanying him further in his "Discourse," but we have perhaps proceeded far enough to indicate that the objects which caused the Sylva to be penned once again face the nation. Planting has become, for a variety of reasons, differing in degree but not in essentials, one of the most imperative duties the nation is called upon to see to. It may be held that this is not the time to preach this crusade. We know that this is the excuse being given. But we also know that the nation is more wide awake in war time, more intent on setting its house in order. Putting off the work is merely to delay the time at which the crops will become ready for the axe. We have not to wait the hundred and more years necessary in Evelyn's 
day, for we do not need now to produce oak for building the old "wooden walls" of the country. Shorter periods will raise the crops we most require, but nevertheless these crops are as urgently needed to be planted by us in the interests of our posterity as were the oak trees for which the Sylva was in the first instance written, though the author, as a matter of fact, dealt with many species besides the oak. Planting work is not difficult. We know the species to use. In fact they and their characteristics were known to the Classic poets of old. As Evelyn says, Virgil (Georg. II) might have been writing of the beautiful woods of this country, now but a fraction in extent of what we require, in his well-known description (I quote the translation in the Sylva)-

Some trees their birth to bounteous Nature owe; For some without the pains of planting grow.

With osiers thus the banks of brooks abound, Sprung from the wat'ry genius of the ground: From these same principles grey Willows come; Herculean Poplar, and the tender Broom.

But some from seeds inclos'd in earth arise :

For thus the mast-ful Chestnut mates the skies. Hence rise the branching Beech, and vocal Oak, Where Jove of old oraculously spoke.

Some from the root a rising wood disclose; Thus Elms, and thus the salvage Cherry grows. Thus the green Bays, that bind the Poet's brows, Shoots, and is sheltered by the mother's boughs. These ways of planting Nature did ordain, For trees and Shrubs, and all the Sylvan reign. Others there are, by late experience found.

This planting question should no longer be delayed. Our waste lands should no longer be left unproductive, 
Is the nation going to see to it that this work is carried out? And may the nation hope that that Great Society which soon after its inauguration, as I implicitly believe and as Evelyn put it, awoke in the country the spirit for planting and thereby saved us from invasion in the days of Napoleon, will come to its aid once again and by its powerful support help us to secure that area of home woods which present-day necessities demand, which a full utilisation of our national resources and the campaign for thrift in all departments of life equally demand, and which our posterity is likely to so sorely need. 



\title{
FORESTRY AND THE WAR
}

\author{
PART I \\ A NATIONAL PLANTING SCHEME \\ I
}

FORESTRY : WHAT IT MEANS TO THE NATION

For some years past forestry, by which is understood the afforestation, or re-afforestation, of portions of the waste lands of these islands, has been receiving a rather desultory consideration at the hands of the Government of the day. At various periods in the last score of years Royal Commissions have examined the question (and numerous witnesses), and have issued the results of their labours in voluminous Blue-Books. The appearance of these latter has afforded opportunities for animated discussion amongst experts and those claiming some knowledge of forestry. But they have remained a dead letter so far as any practical application of the suggestions they have contained with reference to afforestation on a large scale in the interests of the nation.

There are millions of acres of what has been termed waste lands in these islands, variously estimated at 
4,000,000 acres in England, 4,200,000 acres in Scotland, 700,000 in Wales, and $1,500,000$ acres in Ireland. It may be said at once that a considerable proportion of this area is suitable for tree growth; there are also about $I 6,500,000$ acres of mountain and heath land in the two islands, part of which could be afforested. By planting up a portion only of the suitable tracts a large sum of money, which at present goes out of the country to pay for timber imports which we could grow ourselves, could be retained and be disbursed amongst our own people. Some of our best blood also, which up to the commencement of the great war was emigrating, could find congenial employment at home at the end of the war either in the woods or in those industrial businesses and factories which arise in the neighbourhood of wooded areas of sufficient size.

It will be asked why, with a great war on our hands, worry about such problems as this one connected with forestry, since up to the outbreak little had come of the labours of various Commissions, that therefore the matter could not have been considered, either by the Government, the politician, or the economist, as of vital importance in the interests of the nation. The answer is to be found in the very fact of the incidence of the war and the unprecedented effect it must have, so far as the cheaper forms of timber are concerned, on the timber markets of Europe, if not of the world. Now, in these markets the United Kingdom up to July I9I4 unfortunately reigned supreme, so far as our demand and our imports are in question, for we took approximately half of the total world's imports of forest produce, 
At first sight the war would not appear to affect this matter, since we retain the command of the sea. That prices would rise in the event of a European war was a foregone conclusion. That they have risen for certain materials to an unprecedented degree is of course due to the closure of ports in the fighting areas, to German submarines, and to the shortage of freight vessels, so large a proportion of the mercantile marine being occupied with transporting troops and their impedimenta and supplies; whilst German vessels have disappeared from the oceans. Such rises are merely incidental ones, which the opening of the ports and an addition to the available vessels for transport purposes, other conditions remaining the same, would readjust to some degree.

But there are other increases in prices which the end of the war is unlikely to see sink to their former levels. Much of the cheaper timbers used in the building trade and for numerous other purposes fall within this category. It will be admitted by those who have followed the course of the operations of the war, provided they have some first-hand acquaintance with the terrain in which it is being fought, that a very considerable destruction of forest is taking place and has taken place within the fighting area. To this must be added enormous amounts of timber felled and used up in the preparation of trenches and fortified lines, which now run into many hundreds of miles; in the provision of sleepers for the network of light railways behind the firing line and elsewhere, and so on. Young pole growth (i.e. young sapling woods) has been sacrificed wholesale to form corduroy roadways and for other 


\section{FORESTRY : WHAT IT MEANS TO THE NATION}

purposes. The destruction which has already taken place in this manner in Belgium, North France, and Poland must be immense. As is well known, Germany has been making wholesale fellings in the Belgian forests, and transporting the timber so cut into her own country-to save, doubtless, felling in her own woods.

The result of all this destruction must inevitably react on the supplies available for use by the countries in which it has taken place. In other words, we must expect in the future to meet these countries as competitors in markets to which up to now they have not had to resort to any great extent. This is one point which should receive early and serious attention. But there is another which, although it has a direct relation to the above, is really distinct, and requires to be considered apart. It falls within the category of passing or temporary problems, but it is likely to prove for us an exceedingly unpleasant one, and, so far as can be foreseen, an expensive one to boot.

How are the towns and villages, the farms and tenements of all kinds of stricken and devastated Belgium to be rebuilt? How those of France and Poland? House-building at the close of the war will be on a gigantic, a hitherto undreamt-of scale. Enormous amounts of timber will be required, of the cheaper kinds of timbers which are known to commerce as soft woods; these are practically all conifers-pines (red and yellow deal), spruces, and firs (white deal) and the larches.

It will be interesting and instructive to consider for a. moment where these materials chiefly come from. 
We ourselves grow only insignificant amounts, usually absorbed and used locally, and now being cut out to supply a great deficit in imports. Our main supplies are imported. The bulk of these come from Europe, chiefly Russia, Sweden, and Norway, with smaller amounts from France, Germany, and Austria-Hungary. Both Germany and Austria-Hungary, it is interesting to note, possess large areas of well-conserved and managed forests, although their exports to us in the past have been comparatively small. Of the materials here considered, the bulk of the supplies, outside Europe, come from the United States of America and Canada. The export and import of heavy forest materials such as timber from and to any country is determined by the geographical position of that country. For a long time Sweden and Norway, e.g., have been felling their woods, and exporting the materials both to Europe (Great Britain, France, Germany, Belgium, Holland, Spain), and even to Africa and the Cape. Austria-Hungary before the war sent material to Germany, Italy, France, Greece, Turkey, Rumania, all of whom are her neighbours. Canada and the United States export their materials by the Pacific to Asia, and by the Atlantic to Great Britain, France, Portugal, and Germany. Russia exports largely to Great Britain-also, before the war, to Germany, France, and Holland.

From our point of view, the great exporting country of cheap woods is Russia, who sent us in I9I3 about $£ 15,000,000$ sterling worth of wood materials out of our total import of forest produce for that year of $t 42,725,000$. Since I hold the opinion that our im- 


\section{FORESTRY : WHAT IT MEANS TO THE NATION}

ports during the next thirty to forty years must largely come from the Russian forests, I deal fully with this subject in Part II. of this book. Next to Russia in importance come Norway and Sweden. These three countries send us the bulk of our supplies of these soft woods, either in the form of split or sawn, planed or dressed logs, or as pitwood for the mines, or as wood pulp, in such large demand for paper-making.

The question, therefore, presents itself, What effect is the exceptional demand for these soft-wood timbers for house-building, etc., in the devastated countries likely to have on our home market-i.e. on the European timber market-in face of the great competition which it appears must inevitably arise with the advent of other European countries as bidders? Building timbers will not be the only requirements. Wholesale refurnishing will also make considerable demands on the supplies. Unless very careful arrangements are made before the war closes, it appears inevitable that we shall suffer, that our numerous industries which make use of timber of varying quality as a raw material will suffer, to a ruinous extent.

As a nation we shall be helpless in the timber market, for we have no supplies of our own which, carefully husbanded, would enable us to tide over the next few years. Even in the pitwood market it was calculated in November I9I4 that our total resources of this material in plantations in the country would be exhausted in two years! Since the commencement of the war fellings and thinnings have been made in many of our woods to take advantage 


\section{CLASSES OF WOODS NOW BEING FELLED IN BRITAIN}

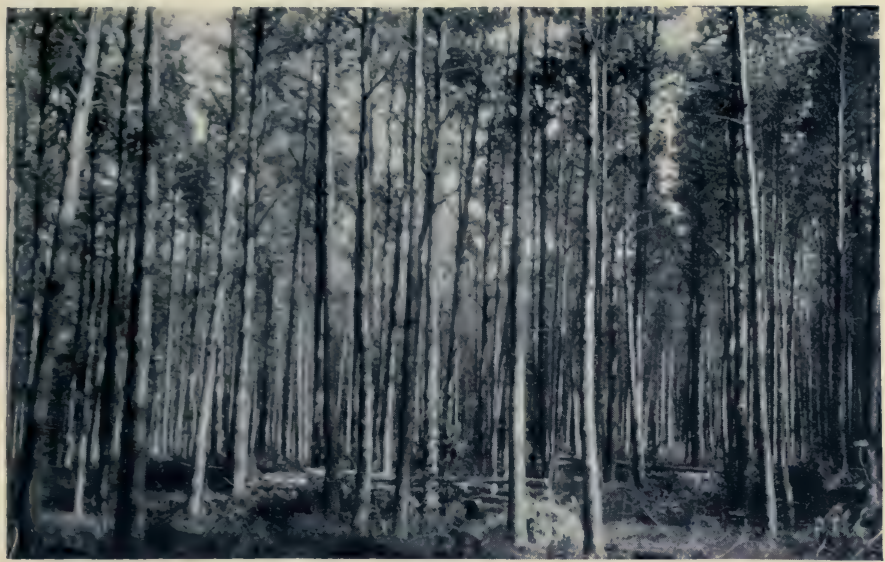

Scots Pine Wood at Strathord, Near Stanley, Atholl Estates, 42 YEARS OLd.

A small thinning just made, August r9r3 (Pitwood size).

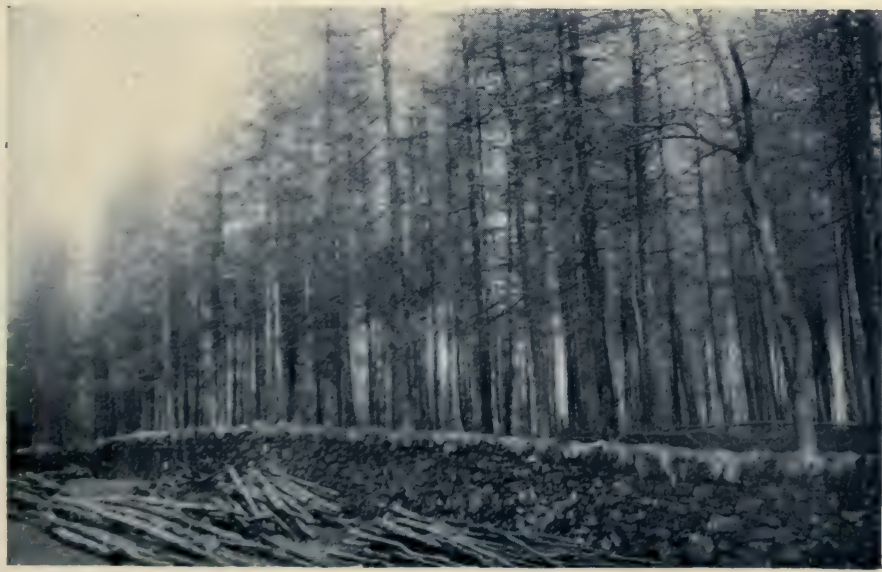

Craig Vivian Larch Wood near Dunkeld, Perthshire, 3 I Years Old

A thinning just made, March I914 (Pitwcod size). Fhotos ky Author. 

of the rise in prices for this material. Some of these fellings have been distinctly to the good, since they have enabled proprietors to get rid at a profit of poorly grown or wind or snow-broken woods-woods which two years ago would not have paid even the cost of felling and removal of this class of timber (vide $\mathrm{Pl} .8$ ) ; for it could not compete with the foreign imported product of the same class, but infinitely better grown. But the amount of material so provided has been a mere drop in the ocean of the demand which exists. And we are now exploiting our better-class commercial woods. Heavy fellings are now being made in these woods both at the instance of Government and in the interests of wood merchants. A Home Timber Committee has been appointed by Lord Selborne. It was a wise move and well timed. But its chief duties at present-its only duty of any importance-is connected with the cutting down of such of the woods in this country as have a present commercial value. Its reference of appointment was confined to this matter. In spite of the very high rates as compared with pre-war prices now in force, no stipulation was imposed by Government demanding that the woods disposed of in such a lucrative fashion should be at once replanted. There are two points in connection with these home timber fellings which might, without undue hardship, be insisted upon : (a) all woods purchased and felled by Government at the present high rates should be at once replanted by the owner as a condition of contract; $(b)$ the Home Timber Committee should keep a careful record of the amounts of material cut from the areas they purchase, 
its nature, locality in which grown, etc. ; for such a record will prove most valuable in future planting operations.

From the foregoing it will become apparent, even to the man in the street, who pretends to no first-hand knowledge of the aims of forestry in a country nor of the timber markets of the world and their idiosyncrasies, that the present position would appear to require immediate consideration, and firm yet delicate handling, with the object of arranging for our future needs in timber, etc., and in order to prevent serious and unnecessary competition in the European markets at the end of the war. For, as matters stand, such competition would take place almost solely between ourselves and our Allies. The problem requires organising to prevent corners being made by speculators. Steps should be taken to ascertain so far as is possible the amounts of timber which will be required for the rebuilding of the houses within the devastated area; we should endeavour to ascertain in good time the available amounts of timber for export in Russia, Norway, and Sweden; and from our own Empire, Canada, Newfoundland, etc., and, finally we should come to a definite understanding with our Allies under which some arrangement with reference to the timber available for export should be made in order to prevent a competition which would send up prices to a ruinous extent.

Since the United Kingdom has been by far the largest importer in the past, and is consequently the country which will feel competition in the markets the most severely, it would seem to be our business and to 


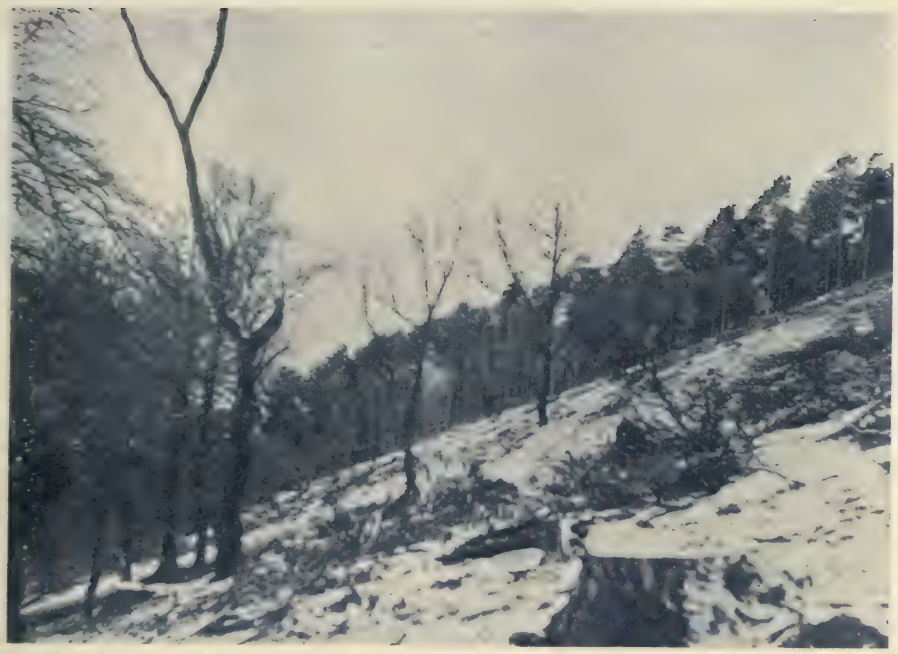

Newly Fflled Area as Left Uncieaned by Timber Contractor.

The area will have to be first cleaned by the forester before planting up. Peeblesshire, February rgr3. W. A. Fraser, photo.

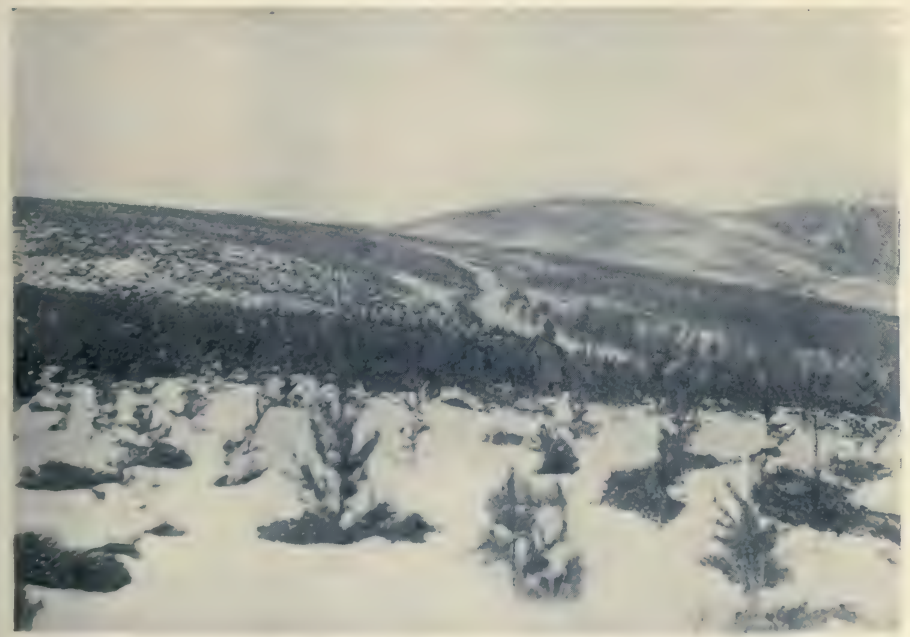

Yocxg Plantations on the Haystown Estate, Peeblesshire. A wind-swept rilge in foreground which has proved difficult to plant up. 

our interest to take up this matter, and to come to an understanding with our Allies on the subject, and, if possible, with neutral countries such as Norway and Sweden, as soon as possible.

In this connection one of the first problems requiring solution is, as has been indicated, to ascertain the amount of timber which it will be possible for Russia, Norway, and Sweden to export for the next few years. It should not prove a difficult business to obtain fairly close enough estimates of these amounts. Russia, as is well known, has vast forest resources, and, as will be shown, she has been one of our chief suppliers for some years past. But to tap these supplies capital will be necessary, and organisation. With the inflated values of timber it may be thought that capital should be easily forthcoming. But the war will not leave Russia with any capital to devote to the purpose, a business in which she will not have as vital an interest as we ourselves. We shall be the hardest hit by a failure in our timber supplies, as we are in fact at the present moment. As regards neutral suppliers, Norway and Sweden might be inclined to hold up their supplies and be unwilling to cut up to their annual increment, or even over it, to take advantage of an enhanced market, in the hope that prices might go higher. Any action tending to the holding up of supplies at the end of the war would have serious and disastrous effects, and the risk should be removed by previous agreement between the parties concerned. Whatever steps it may be decided to take, it would appear advisable for the Entente Powers to discuss and settle the problem. For none will have money to fritter away in operations 
which, owing to unnecessary competition, are rendered more costly than they need have been.

We may now briefly look a little further forward, and examine the position of affairs as it is likely to affect this country for the next score or two of years. It is probable that we are faced with a permanent increase in the price of timber materials.

What action should then be taken by the nation? Should we not take up this afforestation problem in a business-like manner, and give up treating it as either a plaything of the politician or an amusing if expensive hobby of the landed proprietor!

Some beginnings of State afforestation have been made in Ireland. The conditions in that island favoured the acquisition of land by the State for the purpose. In England and Scotland the conditions are different. Education in forestry has been receiving the close attention of the Development Commissioners, and very considerable progress has been the result. Some of the larger city corporations have commenced to afforest the catchment areas of their water supplies. A few of the largest landed proprietors, especially in Scotland, have considerable areas of woods managed on a commercial basis. Broadly speaking, this is the present position. We shall discuss it at greater length in a subsequent article. Afforestation from the commercial point of view, the only point of view of any real value to a country requiring the large amounts of raw forest material annually needed by us for our industries, our manufactures, and so on, has not got beyond the talking stage. To the public at large commercial forestry is still an unknown industry. Its necessity 
and its possibilities are little understood. As a result of this apathy on the part of the nation, we are now faced with a very serious position. It has become imperative, in the interests of the community, that a certain proportion of the plantable waste land in these islands should be placed under woods at as early a date as possible.

How is this to be done?

It will be obvious that it is quite beyond the power (i.e. the purse) of the private individual, unassisted. Forestry is not like agriculture. Long periods have to be passed before the harvest can be reaped, ordinarily sixty to eighty years for timber. It is a State business. Forestry to be a success can only be undertaken on a commercial scale. Large areas are required, and these areas must be in contiguous blocks of from five hundred to several thousand acres of compact woodland. Only in this way can forestry be made to pay as a commercial concern. For with such areas the felling and extraction of the material is facilitated, and the subsidiary industries which arise in countries possessing a considerable head of population can be supplied with the raw products they require. This is not the duty of the private proprietor. He can assist materially when he owns compact areas of woods such as, in fact, exist on a few of the large estates in the country ; or, again, a number of smaller proprietors can similarly assist by clubbing together woods or waste lands lying adjacent to one another, and working them as one area under a trained forester. The small areas of woodland dotted so picturesquely over the countryside in these islands 
are useless from the commercial forestry point of view. Nor can their owners make them pay or expect to be able to do so, since there is no continuity in supply of materials from such areas, and without such continuity it is not to be expected that the wood merchants will be able to offer a remunerative price for the timber, nor can the railway companies be expected to provide cheap facilities for its transport. These have been the troubles of the past. They have been gradually coming more and more into focus. The Great War has brought them to a head.

The question, then, before the nation is-How are we going to set about the afforestation of our large waste areas on a scale commensurate with our necessities, in order that succeeding generations may not be left entirely at the mercy of foreign countries so far as its timber requirements are concerned? For this is our present position. 


\section{II}

THE POSITION OF THE AFFORESTATION QUESTION IN BRITAIN AT THE OUTBREAK OF THE WAR-AND NOW

In the introduction to these articles attention has been drawn to the remarkable parallel existing between the afforestation question as it confronted the country in the early days of Charles II and the present time.

We are in infinitely better case to-day, for we have not now to wait the long periods necessary for the growth of large oak timber such as was required to build the ships of the old Navy before the introduction of the steel-built vessel. Thirty-five to forty-five years will suffice to produce pitwood crops and paper-pulp wood, and double this period most of the other conifer wood we so largely need.

Before dealing with a suggested planting scheme for this country, it will be advisable to glance at the more recent past history of the afforestation question, and to visualise the extraordinary, the startling, apathy in the light of our present war requirements in timber materials, with which the whole subject has been regarded in the past by Government and public alike.

To briefly recapitulate the earlier part of the history of this matter. We have seen that the planting revival which took place in Evelyn's day as a result of 


\section{I4 POSITION OF AFFORESTATION QUESTION}

his work carried out under the auspices of the Royal Society was successful in providing the Navy with its requirements a hundred years later. It has also been shown that this excellent work was not continued after I820 or thereabouts. The nineteenth century saw a change in the materials required for shipbuilding and the removal of import duties from colonial and foreign timber; economic factors which may be said to have sounded the death knell of British forestry, already in a moribund condition. It became unprofitable. And yet it had been a profitable rural industry for centuries in this country. It was not that the industry would not still pay. It was simply that the old English methods of growing timber which dated from 1540 or thereabouts, and which in that period had spread throughout this island and across into Ireland, no longer provided the clean stems free from knots required by the market. The markets had changed both in this respect and in the kinds of timber (species of tree) they required, and we continued on the old lines growing material for which there was no demand. ${ }^{1}$ Practically throughout the latter half of the last century the woods came to be looked upon chiefly from the point of view of game coverts and ornaments to large estates. We depended almost entirely on imports for our supplies of forestry materials.

It is not proposed to burden this article with a wealth of statistics. Figures, we all know, can be made to show anything. But it will be necessary to glance at the areas of land in Great Britain and Ireland and

1 This subject is dealt with at greater length in Article XII, pp. 163-5. 
the proportion of woodland and mountain and heath land to total area. Roughly speaking over nine-tenths of our wood imports are of coniferous timber. Now coniferous trees are just the class of trees which we could grow, and grow successfully, on our derelict and waste lands, which aggregate roughly over $16 \frac{1}{2}$ million acres. Britain, once covered with forests, is now one of the most poorly wooded countries in the world. The land areas are roughly as follows :

\begin{tabular}{|c|c|c|c|c|c|c|c|}
\hline & & & \multirow[b]{2}{*}{ Land Area. } & \multirow[b]{2}{*}{ Woodlands. } & \multirow{2}{*}{$\begin{array}{l}\text { Mountain } \\
\text { and Heath } \\
\text { land. }\end{array}$} & \multicolumn{2}{|c|}{ Percentage. } \\
\hline & & & & & & $\begin{array}{l}\text { Wood- } \\
\text { land. }\end{array}$ & $\begin{array}{l}\text { Waste } \\
\text { land. }\end{array}$ \\
\hline $\begin{array}{l}\text { England } \\
\text { Scotland } \\
\text { Ireland } \\
\text { Wales }\end{array}$ & $\dot{.}$ & $\begin{array}{l}\dot{.} \\
\dot{.}\end{array}$ & $\begin{array}{c}\text { acres. } \\
32,381,000 \\
19,069,000 \\
19,323,000 \\
4,748,000\end{array}$ & \begin{tabular}{|c|} 
acres. \\
$1,666,000$ \\
879,000 \\
303,000 \\
182,000
\end{tabular} & $\begin{array}{c}\text { acres. } \\
2,306,000 \\
9,375,000 \\
3,780,000 \\
1,251,000\end{array}$ & $\begin{array}{l}5^{\circ} \cdot 1 \\
4^{\circ} \cdot 5 \\
1 \cdot 5 \\
3^{\circ} \cdot 8\end{array}$ & $\begin{array}{r}7.1 \\
48.1 \\
18.5 \\
26.2\end{array}$ \\
\hline \multicolumn{2}{|c|}{ Total. } & - & $75,521,000$ & $3,030,000$ & $16,712,000 \mid$ & $3^{\circ} 9$ & $2 I^{\circ} 6$ \\
\hline
\end{tabular}

The percentage of woodlands in Great Britain and Ireland is 4 only. The area of mountain and heath land runs to over $16 \frac{1}{2}$ million acres, and much of this at present brings in a very small annual return, roughly, save in exceptional circumstances, from $2 s .6 d$. per acre to a few pence per acre only. There is a good deal of the latter in Scotland.

I will commence by briefly indicating what we have been doing towards attempting to ameliorate the returns from this poor land.

During the past quarter of a century several Committees have been appointed to deal with the forestry question. The result, so far as the actual planting of 


\section{I6 POSITION OF AFFORESTATION QUESTION}

woods for commercial purposes is concerned, has been nil. Not a tree has been planted. In 1887 a Parliamentary Committee considered this question and made recommendations. Had these been given effect to and had planting on a considerable scale been undertaken as a result, we might now have had a series of woods from which we could have drawn a supply of pit timber for the mines. Well-grown woods of this age are, where they exist in this country, actually being cut down for this purpose at the present moment. But we did nothing! Again in 1902-3 a Departmental Committee of the Board of Agriculture reported on the subject. Unfortunately it did not advocate any large planting scheme, but made valuable recommendations on the subject of a more extended system of forestry education. Effect was given to these recommendations in different parts of the country, and the question has since received hearty support from the Development Commissioners. But no planting was done. In 1908 a Committee appointed by the Department of Agriculture in Ireland recommended a scheme of planting up 700,000 acres in that country. Purchases of land for this purpose by the State were commenced in Ireland and the work has since received considerable support from the Development Commissioners, and what may be termed a State Forestry Department has come into existence in Ireland.

In 1906 the Royal Commission on Coast Erosion and Afforestation was appointed. The Committee examined numerous witnesses, including all the expert advice procurable, and issued its Report in 1909. This Report recommended the planting of $9,000,000$ 

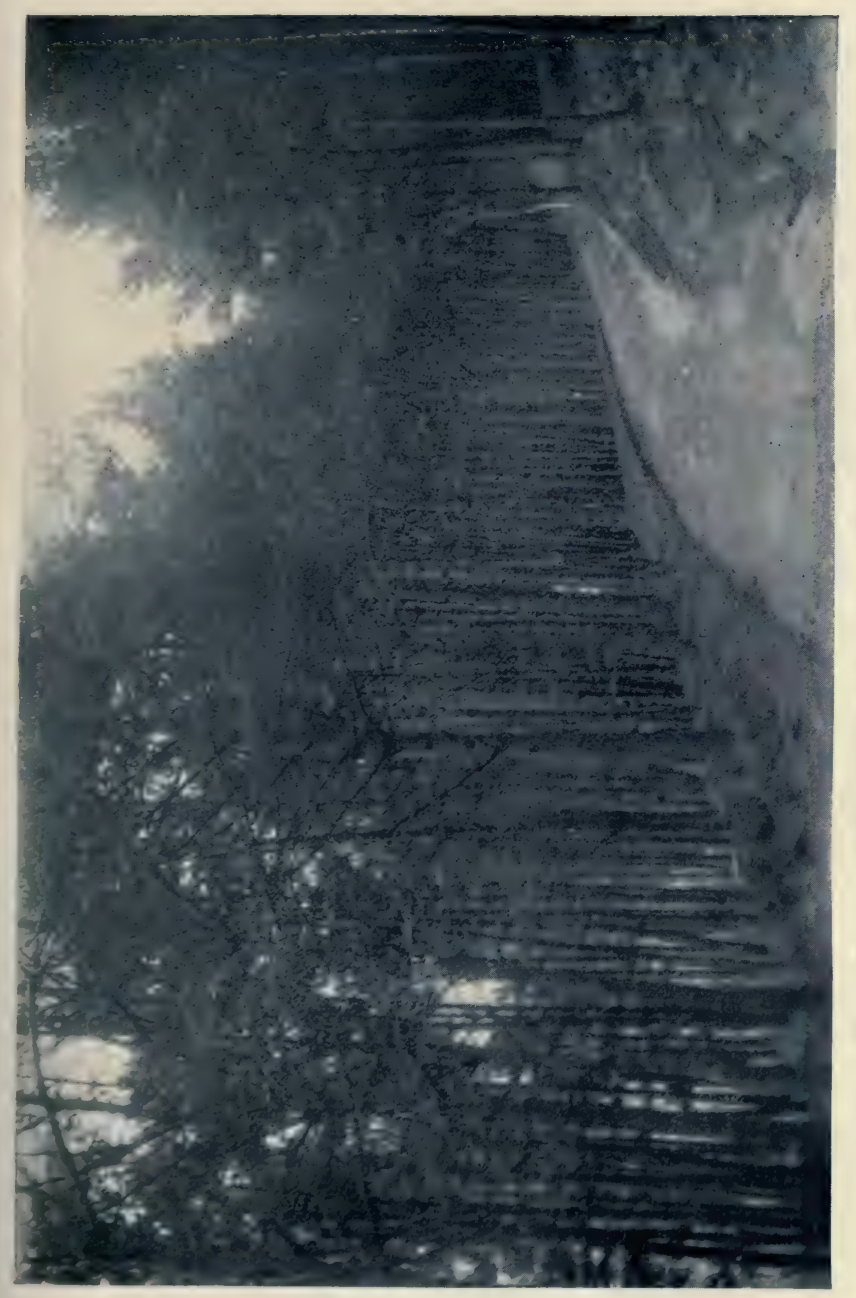

อิ

气

1)

$+$

惫总

동

되을

Ar 뭉

म

일

$\angle 9$

娄

$\infty=$

คำ

3

3

य

S

A

㲾 

acres by the State, of which $6,000,000$ were to be planted in Scotland and the balance in England, Wales, and Ireland. With the exception of Ireland nothing was done. No planting was undertaken in Great Britain.

In I9II a Departmental Committee on Forestry in Scotland was appointed and issued its report in I9I2. In addition to recommendations on the subject of forestry education and the acquisition of a Demonstration Forest Area, the question of afforestation in Scotland was considered. Flying surveys of the country were advocated in order to ascertain the available planting areas, the establishment of a limited number of State trial forests, and the appointment of an Advisory Forest Officer. The last recommendation of the three has been given effect to. In I9I2 a very practical Report appeared entitled "A Forest Survey of Glen Mor and a consideration of Certain Problems arising therefrom." This Report was drawn up by Lord Lovat and Colonel Stirling of Keir, late President of the Royal Scottish Arboricultural Society, and was published under the auspices of that Society.

The following extract from the Preface gives the reasons aimed at in the preparation of this Report :

"This survey is the first serious attempt to grapple with the economic difficulties which confront afforestation in that part of Great Britain" (to wit, Scotland) "where the largest extent of plantable land-that is to say, land sufficiently good and sufficiently cheapis to be found. It would have been easy to select an area where most of these difficulties would have been avoided, and to create a forest under ideal sylvicultural 


\section{I8 POSITION OF AFFORESTATION QUESTION}

conditions within a ring fence. Such areas do exist, and no one will deny that they have the first claim on afforestation. But if sylviculture is to become a leading industry in the Highlands of this country, as it is in those of France, Belgium, and Germany, and to be an important source of national wealth and national employment, as it is in those countries, it must invade the wintering of the high sheep farms and deer forests which occupy the bulk of northern Scotland. The writers have therefore, at the request of the Council, deliberately set themselves to face the difficulties which have there to be met.

"The Council believes that the Report establishes the following propositions:-

"I. That it is possible to create forests in the Highlands, even in districts where the economic conditions appear most adverse, without seriously impairing existing sources of wealth.

"2. That afforested areas will, even in the early stages of the movement, gain greatly in employment and population.

" 3 . That the actual work of planting can and ought to be cautiously begun as soon as the progress of the Survey justifies the selection of definite areas."

This Report in effect practically drew up what the scientific forester would term a Plan of Operations for the afforestation of 60,000 acres in Glen Mor, through which runs the Caledonian Canal. To those interested in the matter and to the nation at large, a perusal of this interesting and valuable scheme may be recommended. The war has doubtless altered to some extent some of the economic problems upon the existence of which the Report is based, but its undeniable value still remains, 
The Development Commission was appointed in May I9I0. During the six years of its existence it has enthusiastically taken up the forestry question. Briefly, at the outbreak of the war as a result of the work of the Commission the position was as follows. In England the counties had been formed into natural groups and a Forestry Adviser been appointed to each group, the salaries of these officers being paid from a grant from the funds at the disposal of the Commission. In Scotland an Advisory Officer to the Board of Agriculture had been appointed and Advisory Officers were being appointed in the west and east of the country. The Forestry Advisers in both England and Scotland were attached to either the University or Agricultural College existing in their centre. But the Commissioners had gone farther than this. They recognised that if the large areas of waste land existing in this country, eminently suitable for afforestation, were to be planted up, it was no longer possible to expect private proprietors to be able to find the necessary money. In fact, they realised that the work had now become a national one. The problem was admittedly difficult, but after careful inquiry into the various conflicting interests they offered a solution on the following lines.

The owners of the greater bulk of the afforestable land in blocks of size suitable to achieve the aims of commercial forestry consisted of large City Corporations, Water Trusts of the great cities and towns possessing large catchment areas, and large landed proprietors.

To such bodies and proprietors the Commissioners 
were prepared to provide money for afforesting suitable areas on the understanding that the land should be reserved for afforestation on commercial principles for at least one complete rotation. No rent would be paid for the land, but the landowner would receive a fair share of the proceeds for the timber grown on the area. The Commissioners would advance the money required for the planting work. The landowner's share of the ultimate proceeds would be based on the proportion which the value of the land bears to the estimated capital expenditure required to produce the crop.

The proportion of the receipts to go to the owner of the land were to be a matter of negotiation and arrangement between the proprietor and the Development Commissioners at the start in each case. It would be based on the present rental value of the land, its character and other circumstances affecting the finance of the scheme.

Owing to the necessarily great variation in these data, it was not possible to draw up any general terms of assistance. The only stipulations, or probably the chief ones, laid down for advances of this nature were that the land to be planted should be in a sufficiently large block (500 to I,000 acres) to be commercially exploitable when the woods reached maturity, and that these latter from the time of formation should be skilfully managed in accordance with a previously drawn up working plan and regular inspection by the District Forestry Adviser. It was also laid down that the afforested areas should be available as demonstration areas for the use of students and others 
interested in forestry; a condition which has been readily accepted.

The sums advanced were to be on a maximum basis of $f_{5}$ per acre, including the fencing of the plantations, the loan to carry an interest of 3 per cent.

$\mathrm{Up}$ to the outbreak of the war loans of this nature had been made or promised for the afforestation of their catchment areas to the following Corporations and Water Trusts in England and Scotland:

\section{ENGLAND}

Liverpool.-A large area on Lake Vyrnwy in North Wales is being afforested on the above conditions, Liverpool having led the way in this new departure, readily acquiescing to the condition that the area should be available as a demonstration area.

Manchester.-Has been afforesting her catchment area at Thirlmere during the past twenty years out of funds provided by the Corporation.

Birmingham.- Has a magnificent unplanted area in Central Wales, and has been for some time considering the question of afforesting it.

Leeds.-Is also contemplating the advisability and advantages to be gained by afforesting the land of this nature it possesses.

\section{SCOTLAND}

Edinburgh.-The Edinburgh and District Water Trust have commenced the afforestation of 600 acres of the Talla catchment area, and are also afforesting areas round the smaller reservoirs. The members of 


\section{POSITION OF AFFORESTATION QUESTION}

the Edinburgh Water Trust by their enlightened policy thus led the way in this matter in Scotland.

Lanarkshire.-A scheme for afforesting part of an area of 5,000 acres on the Camps catchment area, owned by the Lanarkshire County Council, has recently been adopted by that enlightened body and the planting work has been commenced.

Other places are also considering the matter, but for various local reasons have not yet started their schemes.

It will be seen, therefore, that a commencement of this important work had been made before the war broke out. Still more significant perhaps is the fact that a number of the business men of the country had shown by their acceptance of the offer of the Development Commissioners that they realised the great possibilities of afforestation in this country. And this realisation had come to them before the war.

The aspect of the question has now entirely changed. As has been shown, the price of timber in the future will certainly be greater than in the past, and afforestation will prove a paying investment.

\section{IRELAND}

The land conditions in Ireland are different and a State Forest Department is now in existence. Land has been purchased and three large centres are now owned by the State, and are being planted out of funds from the Development Commissioners. These areas are in Central Wicklow, County Cork (Ballyhoura), and in Queen's County (Slieve Bloom).

This was, broadly speaking, the position of affairs 
PL. 4.

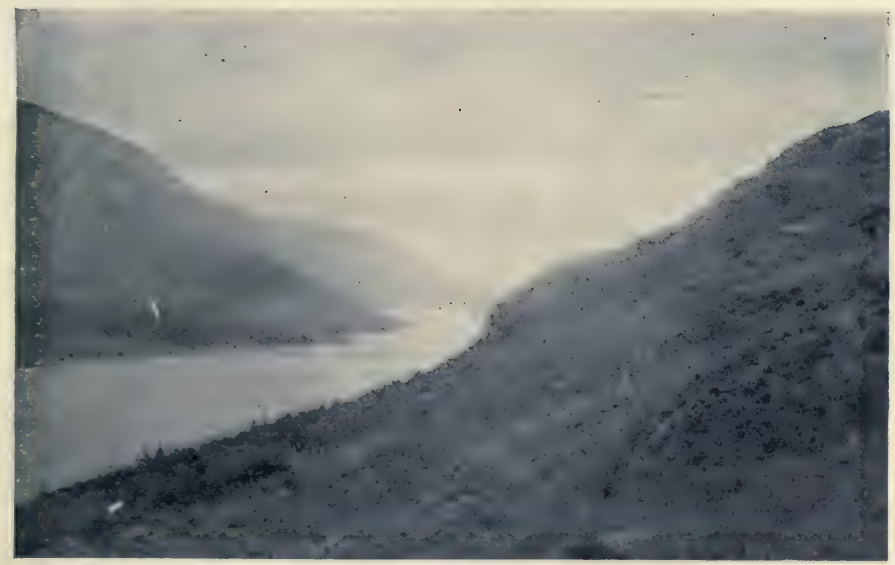

Thirlmere, Lake District: a Catchment Area of the Manchester Corporation, Now Being Planted Up, September igi 3.

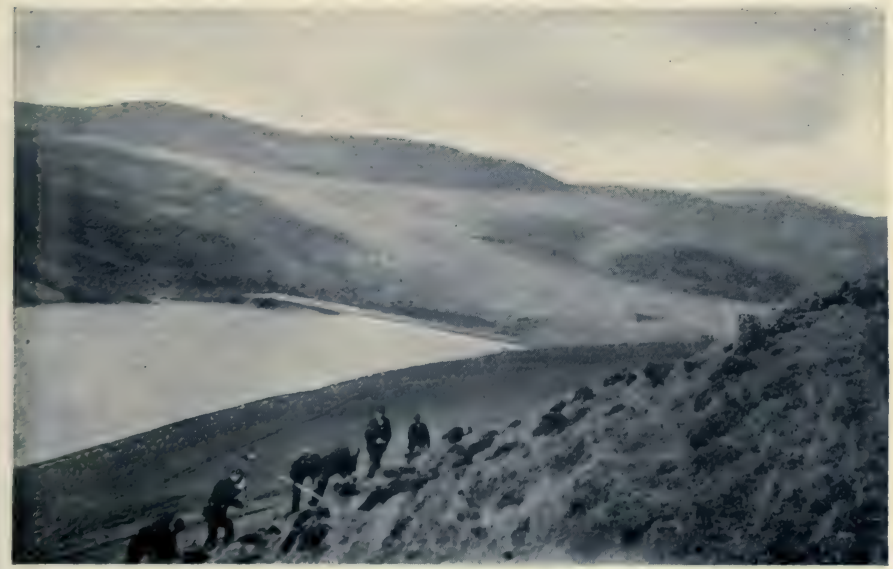

Talla Catchment Area, Edinburgh and District Water Trust, Now Being Planted Up, April 19I4. Photos by Author. 

at the outbreak of war. Now it is not open to doubt that the war has intensified the urgency of the afforestation question in this country. However near to their former level we may be able to bring prices, the tendency of the future will be an inevitable increase. For years the possibility of a timber famine in Europe has been discussed by experts as the probable outcome of the utilisation of the accessible available supplies in different parts of the world. That prices would have risen in a comparatively few years even without the war was a certainty. The war leaves the question in no doubt. Consequently forestry, commercial forestry, will be an even more paying proposition in the future than would have been the case.

And I believe all experts are convinced that far from postponing the matter for any further future consideration steps should be taken now to prepare schemes of sufficient magnitude to ensure both success and adequate supplies for posterity. As a nation we are ever more wide awake in times of stress and danger, and since peace failed to bring this question home to us, even with the numerous Committees and Royal Commissions which have sat upon it, may we not hope that the stress of war and the price we are paying for our fathers' dilatoriness may rouse us to its great urgency?

Had our grandfathers, sixty to seventy years ago, planted up a proportion of the waste lands of these islands we should have been saved a large sum of money and a great deal of anxiety during the past year and three-quarters. Had our fathers planted thirty or forty years ago the pitwood required for the mines would have 


\section{POSITION OF AFFORESTATION QUESTION}

been available in this country, and the great trouble to which mineowners were put and the ruinous prices they are paying for their timber, and we are all paying for our coal, would not have existed. Paper pulp from areas of spruce woods which many parts of our lands can grow to perfection would also be available, and the Press would not be faced with the position in which the action of a neutral and of our own Government has now placed them.

With these facts staring us in the face, will it not strike us that the crusade preached by Evelyn two and a half centuries ago and the spirit for planting-as it was quaintly termed-which it aroused, should once again be raised throughout the country, and that the few who have preached it in and out of season during the last quarter of a century should now have the nation at their back?

After all, it is a question for the country. There are $3,000,000$ acres of so-called afforested land-of woodlands. And we have, say, 9,000,000 acres of afforestable land; put it at $7,000,000$ or even $5,000,000$. It will do to go on with. It has been stated by many who know what they are talking about that this land or much of it will bring in more under trees than under any other form of cultivation; or, to put it in another way, that this land will prove a greater national asset under woods than managed in any other way. Why not then set to work and get it planted up? If for no other reason than the one of national economy, the matter must be regarded as one of urgency. We can no longer afford to leave any source of national wealth unexploited. We must all agree that it has 
become a duty - a national duty - to see that every acre of land in this country is made to bring in the best return possible in the interests of the community as a whole. Well, there exists a considerable acreage of land which experts are agreed is not bringing in anything like an adequate return. This land can be made to grow produce which is in great demand in the country, and which in the absence of home-grown supplies necessitates large imports which have to be paid for, and which are going to be more expensive in the future. The aspect of the forestry problem has entirely changed from its pre-war position. The prices for timber are not likely to fall to their former level. So long as prices were low there was a good deal to be said for those who were against afforestation in this country. The arguments they urged had a certain element of soundness, as, e.g., the contention that forestry would not return even the $2 \frac{1}{2}$ to 3 per cent. claimed for it. The Great War has swept away such doubts and arguments. Prices have gone up and the nation is now assured of successful financial results from its afforesting work. On all counts the planting of this land will be of immense advantage to us. It will save imports, employ labour, and help home industries. In the last connection it will do more than help. It will result in establishing new ones. For the maintenance of a considerable area of forest in a country leads to the establishment of subsidiary industries such as paper-pulp mills, saw mills, bobbin mills, furniture manufactories and so on. And these afford employment to a considerable head of population. 


\section{POSITION OF AFFORESTATION QUESTION}

All that appears to be wanted is a plan of campaign and a favourable hearing from Government. It is not demanded here that additional work should be piled upon already overworked and harassed officials. It cannot be the desire of any one to add any extra burden to the heavy ones already being shouldered by the Government. Rather the reverse. But at the present time it becomes a duty of each one of us to do all in our power in the interests of national economy and thrift. The termination of the war is an indefinite period. Meantime there are large areas of land in this country which can be better utilised in the national interest, given the inauguration of a suitable scheme. Trees take a long time to grow: even the shortest rotation for a tree crop is approximately half of the proverbial "three score and ten years." Therefore each year which elapses without a commencement being made in remedying the deplorable state of affairs is a waste of national resources which can easily be expressed in pounds, shillings, and pence. There are men in this country perfectly acquainted, by knowledge, training, and experience, with such work, who would be quite capable of organising a scheme of this nature and of seeing that the nation got a full return for the capital sum laid out.

Is it too much to expect that the country will realise the economic importance of getting these millions of derelict acres under a profitable crop, and insist on the job being put through? 


\section{A NATIONAL PLANTING SCHEME}

IT has been shown in the previous article that we possess in this island considerable areas of land, running into millions of acres, which are entirely suitable for planting, that these areas are in fact more suitable for growing crops of trees than for any other purpose, and that by planting them up at the earliest opportunity we shall be putting into practice that campaign of thrift, economy, and the conservation of national resources which the Government of the day are so earnestly preaching.

The present position as regards prices of forestry materials has also been alluded to. The important question involved in the application of methods by which these prices can be reduced to a more normal level and that other equally serious one-the question of making some arrangement by which our timber supplies can be placed on a sound basis during the period our newly planted timber crops are reaching felling size-are matters outside the province of this article and will be considered in a subsequent one.

We are here concerned with the afforestation of the derelict areas in this country ; with, in fact, the inauguration of a planting scheme of adequate dimensions. 
The abortive attempts of the past quarter of a century by various Royal Commissions and Committees to tackle this planting problem have been already reviewed. One and all have made recommendations. Almost without exception the urgency and necessity of undertaking planting operations has been admitted. Some of the schemes were too meagre and small; others were said to have been too bold and large. But without exception they met the same fate. Not a plant was put in as a result of the labour given and money spent. The apathy of the public on this subject, an apathy born of ignorance, was complete. And the Government of the day, satisfied with this evidence of the lack of public opinion and public interest in the subject, and being almost equally ignorant of the economic aspects of the case-for were we not getting with ease all we required from across the seas ?-were only too well content to let the matter drop. In those days economy in running the nation was not an urgent business, nor any one's business, nor did it appear to matter that we possessed millions of acres of land-land lying derelict-which could grow so much of the forestry materials which we were content to import and to pay for. The planting of this land would apparently give rise to contention, would be objected to, and so the Government of the day were only too glad to appoint a Commission, let the matter simmer, boil over in the Press, and relapse into oblivion once again.

The position has with so many others altered with the coming of the Great War.

We can no longer ignore the fact that the land is 


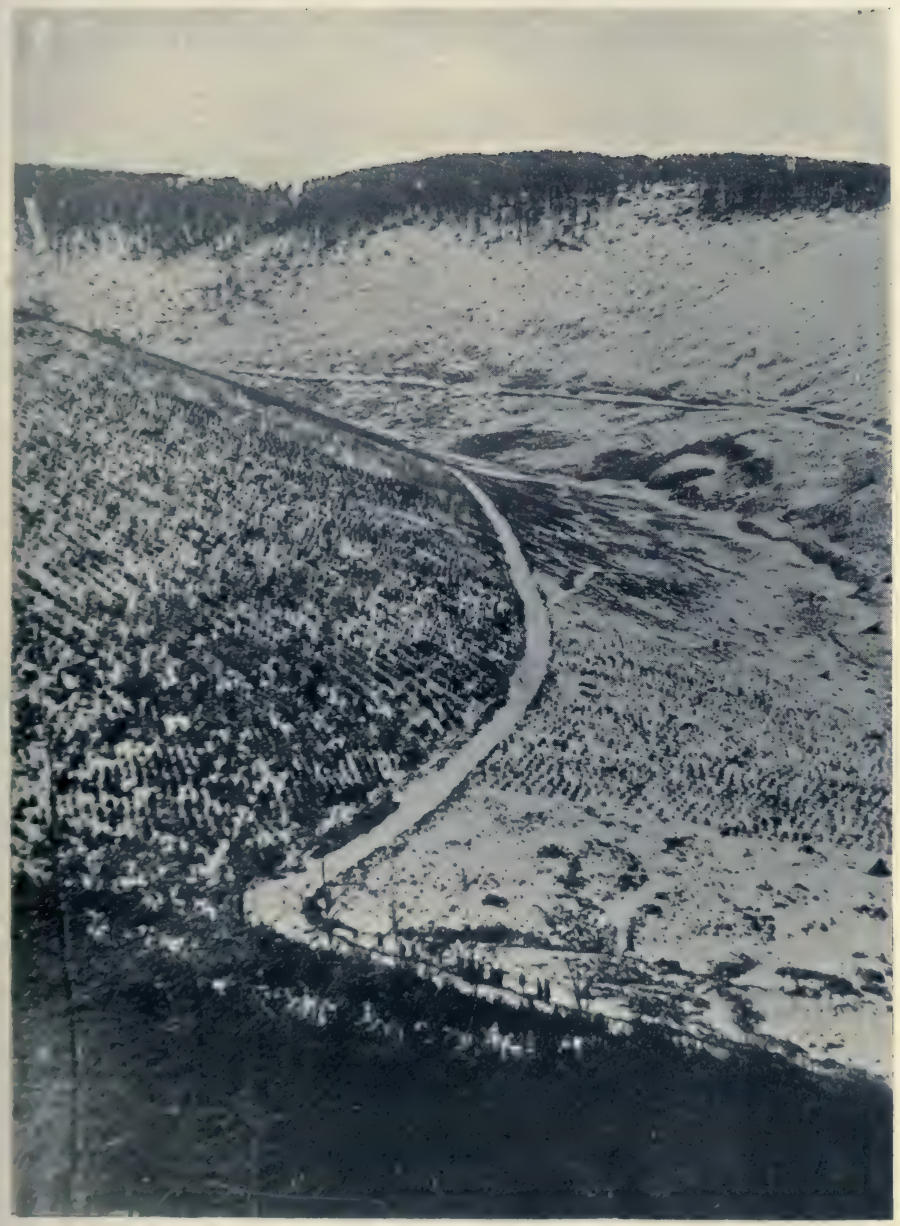

'The Planting Up of a Glen.

Young plantations of larch (ahove the road), Douglas and common spruce (be'ow road), Haystown Fistate, Peeblesshire, February r9r3. IV. A. Fraser, photo. 

there waiting to be planted. We can no longer shut our eyes to the fact that to leave these derelict areas unplanted any longer will be a national disgrace and at the same time prejudicial to all efforts on the part of the Government to preach a thrift campaign. We are aware that immense destruction amongst young pole crops has taken and is taking place on the Continent within the fighting areas (vide frontispiece). In this country we are perforce sacrificing considerable areas of young woods and felling old ones of any value, since we must supply the urgent needs of the country. It is impossible to forecast the future, but that the demand for timber materials forty years hence is likely to be larger even than at the present day is at least a strong probability-and prices will be higher. It rests with this generation to say whether they will leave their posterity to face a worse position, if this is possible, than we are in to-day.

The only safe course, practically the only course, to follow is to undertake at once the planting up of such parts of our available waste lands as are obviously capable of growing a good marketable crop. The selection of such areas would be comparatively easy once a definite policy were laid down and the campaign properly organised. It would not be advisable or necessary during the first few years to deal with exposed areas or to go up to doubtful altitudes. No heroic measures are demanded or necessary. The country has been already divided up into forest districts, each comprising several counties, to each of which a forestry adviser has been appointed. In these districts the most suitable areas for immediate planting are probably 
already known, or could be quickly ascertained; the only necessary stipulation being that the planting blocks should have a minimum size of, say, 500 to $\mathrm{I}, 000$ acres.

The land selected would mostly belong to private proprietors, municipalities, and so on. It would be necessary to come to terms with them. It should prove feasible in certain cases to do this on the lines already laid down by the Development Commissioners on the principle of shared profits, the Government finding the money for planting and fencing up to a certain prescribed sum per acre, and the proprietor of the land and the Government sharing the profits resulting from the crop raised, after the repayment of the loan. The proportion of profits to be shared would naturally vary with the value of the land, and would vary in individual cases. This was the proposal before the war, and as has been shown, was accepted by certain corporations and water trusts.

A more recent offer of the Development Commissioners differs from the above. To meet suggestions made by landowners it is now considered possible that the latter may prefer to lease areas of considerable size for planting, and to receive the annual rental plus a percentage of the ultimate profits from the woods as afforestation value on renewal of the lease. And this would appear an equally fair arrangement to both parties.

Lastly, Government may purchase land for afforestation and become the owner of a certain proportion of the forest area of the country.

The question of national afforestation then may be approached in several ways, all of which, with the 
varying conditions obtaining, are worthy of consideration. To put them as briefly as possible the methods open to us are :

(a) The lease and afforestation of waste lands by Government, the proprietor sharing in the expenses and profits.

(b) The lease and afforestation of waste lands by Government.

(c) The purchase and afforestation of waste lands by Government.

Any one of these methods should produce satisfactory results given a correct choice of method for a particular locality and efficient management. If public funds are to be sunk in this industry, and the war can have left us in no doubt now that a certain sum will have to be allocated for the purpose, efficient management is a sine qua non. Such management can only be obtained by the establishment of Forestry Branches in the Departments of Agriculture with their own personnel and funds. Commercial forestry cannot come into existence in the absence of such branches, and unless the matter is treated solely from the business and commercial point of view the public money devoted to it will be wasted. It is unnecessary here to go into the details of what "efficient management" implies. Both Government and public alike may rest satisfied that they have in this country men who are fully capable of carrying out afforestation schemes without the waste of public money entrusted to them for the purpose. It is no longer necessary to go to Germany to seek advice. In fact, Germany has far too long clogged our feet in this matter, both in this 
country and elsewhere, to the detriment of all real progress. We know what we want, we know what we can do, we know what dangers we have to confront : and once we undertake the proper protection of our woods, a branch which has been entirely neglected in the past, if we except the unnecessary extravagance of protection from vermin, e.g. the rabbit, we can show as good financial results as anywhere on the Continent of Europe. All that has to be settled is which of the above enumerated methods for the acquisition of the areas is most suited to the different local conditions pertaining throughout the country. With that decided Government should be able to allocate funds for the purpose in view with an easy conscience, for it will prove a paying investment both financially and in the national interests.

In connection with the purchase of land by Government a word may be added. Of course where possible this may be regarded as the best method, since full and permanent control ensues. In this case it has often been assumed that the capital invested in the purchase should be recovered from the proceeds of the woods. This is not the case, however, since it is merely a matter of a permanent investment. The Government continue to own the land and with efficient management the quality of the soil, which may be very poor at the outset, will steadily improve when maintained under a crop of trees. The land will steadily increase in value, i.e. will ultimately pay a higher rate of interest.

But however the matter is approached, whether by purchase or leasing in one form or another, the chief desideratum is to get this land planted up. 
If the nation is to face the future and retain her position in the world, she will have to husband all her resources. It is no answer that other nations will likewise be crippled with debt. Some, Germany for one, are likely to recover more quickly than we shall, if the past is any criterion to the future. In any event, we shall not be able to afford to pay $£ 42,000,000$ for forestry products, the bulk of which could be grown at home, on land at present but little productive; nor shall we get anything like the same amount of material in the future for this sum. In the national interest it would be a crime to neglect any longer the raising of as much timber as possible, on the areas at present producing little or nothing of use to the community. There appears little doubt that public spirit and patriotism alone will render agreement between proprietor and Government on this question easy of adjustment. Added to this there is the unfortunate factor that many who before the war were planting on a certain scale may now find themselves unable to bear the expense of such operations. And this at the very time when, in the interest of the nation as a whole, it is most important that planting operations should be extended and carried out on a commercial scale.

The necessity for undertaking planting operations on a large scale having been accepted, the next step will be to ascertain the number of plants it will be possible to obtain for next season's planting work, and to ensure an adequate supply for the following years. Steps have been already taken, to some extent, in this direction. For instance, extra nurseries- 
emergency nurseries-have been instituted in the Crown woods, e.g. at the Forest of Dean, Tintern, Windsor, and elsewhere, where many million plants are being raised for planting out. But many more will be required if planting is to be started on a scale at all commensurate with the nation's needs. A list of nurserymen in this country should be drawn up, ${ }^{1}$ and the amounts of the various commercial species of two, three, and four-year-old plants available in their nurseries be correctly entered. This would give us the number of plants existing in the country, and, therefore, the number of acres which could be undertaken with home produce during the first two years or so of the work. If required-and they probably would be-additional plants could be obtained from certain famous nurseries in the neutral Continental countries. Thus it should be possible, before the next planting season opened, to ascertain definitely the exact area it would be possible to undertake with the plants available."

We now come to the labour question. The question of available labour is left for a subsequent chapter. A planting campaign such as is here suggested could not be left to individual effort. It would have to be inaugurated by a central organisation, e.g. the Board of Agriculture, who would undertake and control the whole of the supply of labour, as also of plants. For this purpose, the most feasible scheme would probably be to raise a labour corps, preferably embodied in the

1 Since this was written a list has been prepared and the approximate amounts available are known.

It is estimated that 10,000 acres could be planted up now with the available plants. 
PI. 6.

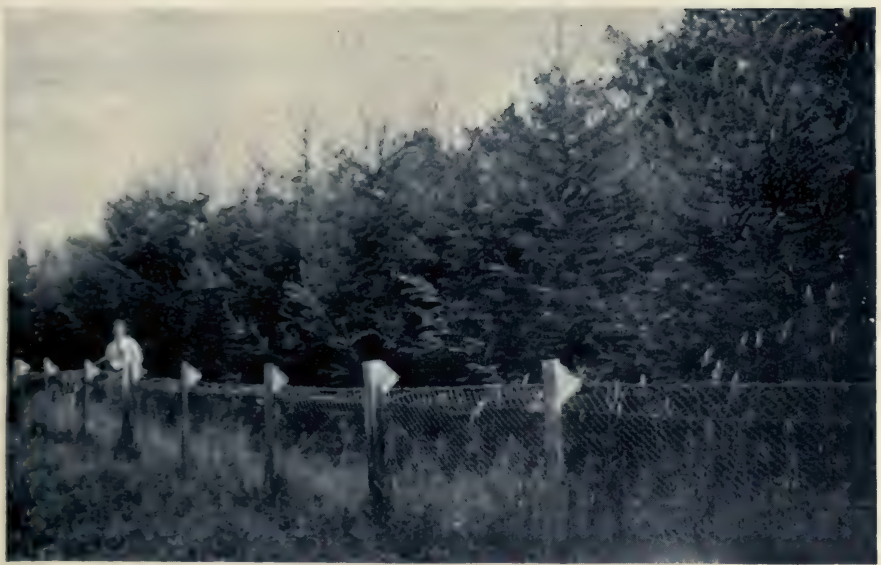

“ Hybrid" Larch Plantation, 7 Years Old, Murthly, Perthshire. Photo August I913.

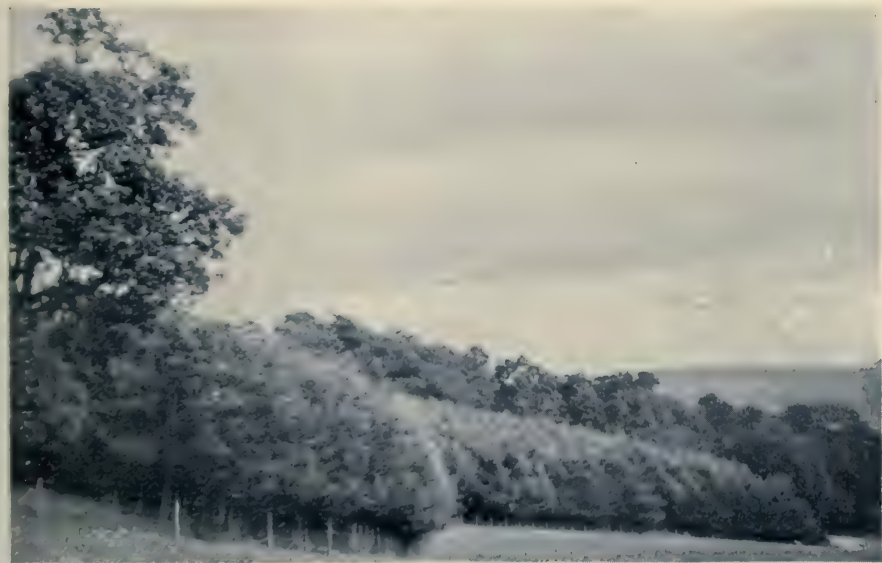

Japanese Larch Plantation, 9 Years Old, Blair Atholl, Perthshire. Photo August 19r3. Photos by Author. 

same way as transport and other labourers have been embodied. In the case of the planting corps, it would be possible to include all refugees who had any acquaintance with forestry work, and a percentage of women. To these might be well added a percentage of prisoners, so long as the war continues, who were cognisant with forest occupations. Drafts from this corps would be sent to the various centres as demand was made for them. The nucleus of the corps would be permanent or appointed for a term of years. The bulk of the labourers would be engaged for the planting season only. Each draft should be equipped with tools, and the corps could be divided up into sections enrolled in different parts of the country with a territorial headquarters under the charge of an officer of the corps.

As regards the finance of the scheme, there should be no difficulty. In the Development Commission there exists a Government body, armed with powers to recommend schemes of this nature for Treasury sanction. All that would be necessary, therefore, would be that the Department receiving the grant should appoint an officer to have charge of a national planting scheme, and give him sufficient powers and funds to carry out the work. The existing advisory officers would make recommendations as to areas to be planted, and, if necessary, assist in the negotiations with the proprietor. If found necessary the powers of the Development Commission could be extended by a short Act of Parliament to suit the needs of the case. The advisory officer would determine the species to be used for planting the areas. The 
officer in charge of the planting scheme would then be responsible for supplying the plants and labour. The plantations when formed would remain under the local estate foresters, the advisory officers being responsible that they received proper supervision and tending to ensure that the objects desired are attained. It is not within the province of this article to discuss the staff which would be ultimately required for the management of the woods so formed. The chief desideratum at present is to plant up available areas of afforestable land within the shortest space of time possible. Experts are well aware that no insuperable difficulties will be encountered in their subsequent supervision.

It is suggested that a plan such as is here sketched would achieve the result aimed at in the quickest and most effective manner. ${ }^{1}$

1 This article and Art. I appeared in The Scotsman, October I9, 26, I915. They have been slightly revised. 
FINANCE AND PLANTING METHODS

THE finance of the afforestation problem may be said to have been the chief stumbling block to progress in the past-finance plus the ignorance and apathy exhibited on the subject by Government and public alike. Reams have been written on this matter of the cost of land, cost of planting, and so forth, but not a single tree has been planted as a result. In fact, since it is always possible to juggle with figures, the afforestation question has over and over again become safely buried beneath masses of statistics. It is therefore proposed to treat of this part of the subject extremely briefly.

In this matter of financing planting operations it may be contended that money will be harder to get now than before the war; interest will be higher; 5 per cent. will be now asked instead of 3 per cent. Granted. But with a return of prosperity this percentage should drop and may even reach 3 per cent. again before the completion of the work. And it must be remembered that the additional cost should be well repaid by the excess price of the wood, which will be, so far as can be foreseen, some 25 to 30 per cent. 
higher than in pre-war days, ${ }^{1}$ as the supplies we have depended upon for the last thirty to forty years become cut out. Further, the investment will be a sound one. For when the woods become ready for the axe our children and grandchildren can utilise the considerable sums which such an investment will give them to defray some of the enormous national debt with which the country will be saddled. If from no other point of view the planting of our waste lands at present bringing in from $I d$. to $2 s$, or so per acre will be a sound investment.

To come now to a practical suggestion. Of the $3,000,000$ acres of existing woodlands, it is extremely probable that the woods of merely commercial value will have been cut out by the end of the war. These woods are being felled firstly at the instance of the Home Timber Committee, who are purchasing areas of standing woods and converting them by Government agency, and secondly and to a larger extent by timber merchants. The Government purchases run into $\mathrm{I}, 000,000$ cubic feet a month-approximately 25,000 B.G. sleepers and 250,000 cubic feet pitwood and scantlings. This exploitation by Government agency, amounting to $12,000,000$ cubic feet or the $\mathrm{e}-$ abouts per annum, would be inconsiderable even if only half the area of our $3,000,000$ acres of woodlands, that is $I, 500,000$ acres, were fully productive. This is certainly not the case, however.

1 The great increase in price of materials during 1915 as compared with 1913 is discussed in Article XIV. Roughly speaking we obtained 25 per cent. less material and paid 30 per cent. more for the reduced amount than in 1913 . 
(2)

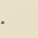

- 


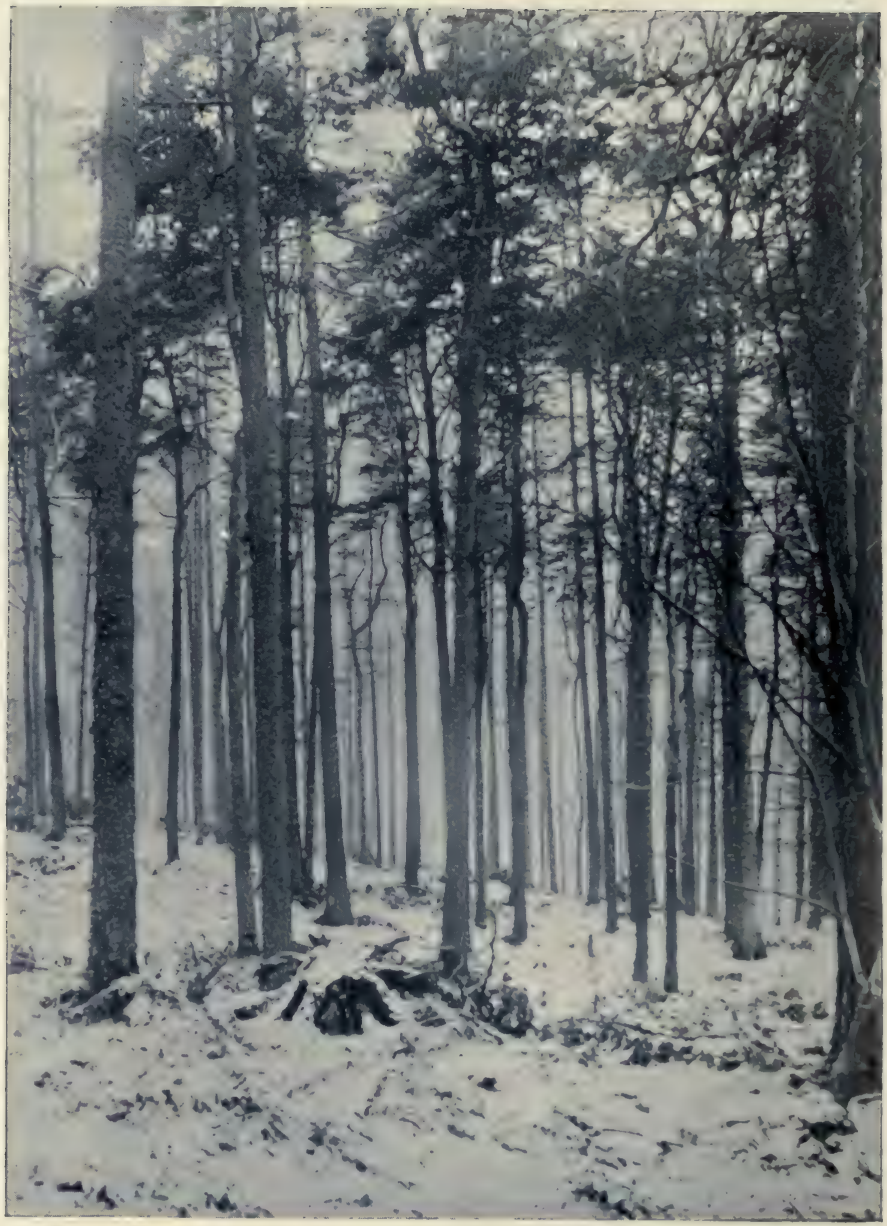

Old Larch Wood with a Few Scots Pine, Much Understocked, Peeblesshire. W. A. Fraser, photo. 
I saw the other day a claim for compensation owing to a fire having occurred in some woods. The largest item in the claim was for an area of wood said to be of pit prop size, the trees growing on an average at 12 feet apart! Woods of this nature and age would be no more than half-stocked and the material of very poor quality. There is a good deal of this sort of thing in the country. Similarly the majority of the old woods of commercial value are very open and understocked. If $1,500,000$ acres were in full bearing they would give under proper management at 70 cubic feet per acre (50 cubic feet final cut and 20 cubic feet thinnings) 105,000,000 cubic feet of mature timber annually on an eighty-year rotation. As these woods are very far from carrying normal crops per acre, the $12,000,000$ cubic feet being cut out yearly by Government-and the total may be larger if all sources of supply are taken into account-together with the far larger annual amounts of wood being felled by timber merchants, must result, if the war is prolonged, in the disappearance of most of our home woods possessing a commercial value. And we have to add to this large areas of immature woods being felled for the necessary supplies for the collieries.

The considerable areas which have a value othet than the purely commercial-i.e., which serve for shelter to stock and crops, are intimately connected with the sporting value of estates, or are maintained for amenity purposes-may be taken at about I, 500,000 acres. These will and should be left standing. They are, in the main, of small size, and would not come within the minimum of 500 acre blocks which commer- 
cial forestry requires if it is to prove successful. There is no reason, however, why the larger areas of this kind should not in the future be managed so as to provide a certain proportion of the large-sized highquality timber required by our industries-more especially of the hardwoods such as oak, ash, sycamore, elm, etc. The maintenance of such areas for sport, shelter, and amenity purposes (Plate 9) is not incompatible with their treatment on sound sylvicultural and commercial lines. These woods are, however, of no considerable importance for our present case. The young commercial woods which have not yet reached felling size must, however, be also included here. The areas which will have been felled (either clear cut or with a residue of worthless trees left on the area), together with the considerable tracts of useless scrub, classed as woodlands, may be taken at $\mathrm{I}, 500,000$ acres. If we add to this area $5,000,000$ acres of the poor-class waste lands which could be profitably planted, we obtain an area of $6,500,000$ acres which, in the interests of national economy, should be planted up at once. Therefore the planting work resolves itself into:

(a) Replanting the areas felled over during the war and the areas at present occupied by worthless scrub (of which there areextensive tracts in Scotland)amounting to $I, 500,000$ acres.

(b) Planting up 5,000,000 acres of at present treeless land, selecting in each county the better areas, which will yield a good return for the capital laid out.

In view of our growing requirements in timber, it is unlikely that this area of $6,500,000$ acres will, when 
PL. 8.

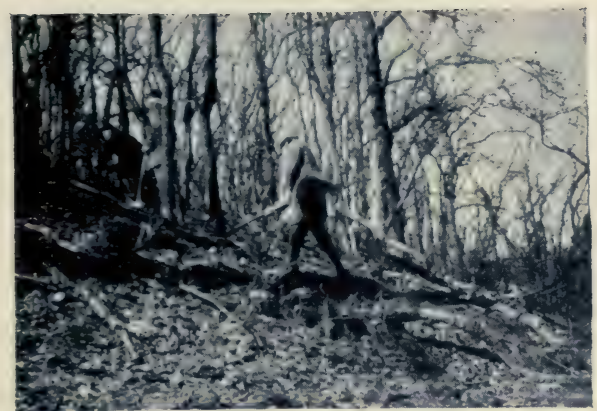

Feling Rotgh OAK Coppice for Pitwood, Hermitage Wood, Dunkeld, Atholl Estate, April igi6.

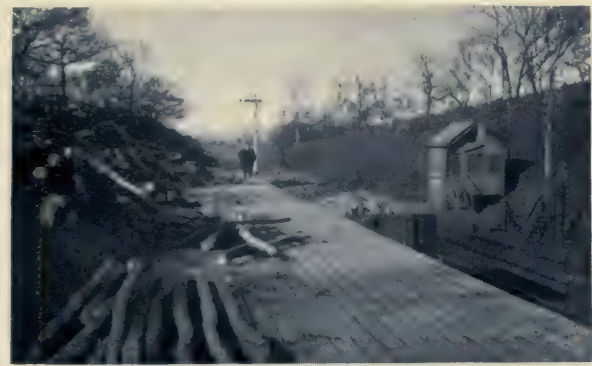

Temporari Siding on Highland RaIlway Near Dunkeld For Load. ING UP OAK PITWOOD, APRIL I9I6.

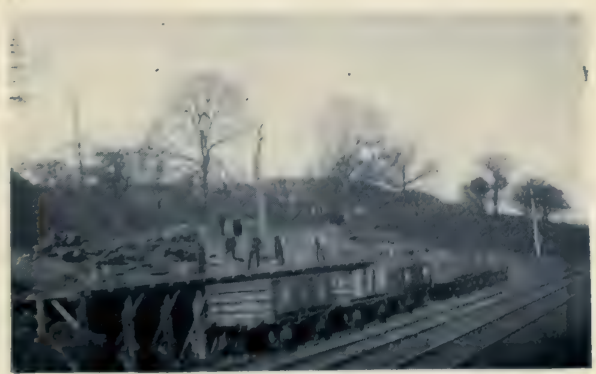

Loading OAK Pitwood into Trucks at a Temporary Siding on the HighlaNd Railway.

Price of the pitwond I8s, par ton loader in truck. The material was cut within a few hundred yards of the siding and was unsaleable hetore the war. April 1916. Photos by Author.

40] 

it comes into bearing, supply us with more than twothirds to three-fourths of our needs of the future. But if the woods are scientifically managed, such an area should place us in a position of safety in the case of a sudden national emergency. Under proper management such an area should yield some 455,000,000 cubic feet of all classes of timber. ${ }^{1}$

On the subject of cost, if we take an all-round sum of $£ 3$ per acre for the felled-over area, etc., class, and $£ 4$ per acre for the waste lands, ${ }^{2}$ our planting cost would come to $£ 4,500,000$ and $£ 20,000,000$ respectively or a total of $£ 24,500,000$ sterling-about a week's war expenditure. If 200,000 acres were planted annually, the area would be planted in thirtytwo years. A planting plan should be drawn up, county by county, under which the felled-over areas, scrub areas, and the most accessible of the waste lands would be selected, and the order of the planting be laid down so as to ensure a proper arrangement of the woods for felling purposes, etc.

It may prove of use here to glance briefly at the nature of the work which has been advocated in the previous articles. It has been shown that our chief imports consist of coniferous timber, pines, and spruces, and that we can grow these species to perfection in this country. In fact, much of the waste land whose afforesting is being considered will grow

1 We imported 454,000,000 cubic foet of coniferous timber and $14,00,000$ cubic feet of pitwood in 1913.

This estimate makes no provision for netting the woods against rabbits. The extermination of this pest is a first necessity in woods managed on commercial lines. 
this class of material and probably no other as a successful commercial proposition.

The greater bulk of the oak, ash, elm, etc., utilised in this country will, as we have seen, probably be raised in the woods kept either for sport, shelter, or amenity purposes, and may to a great extent be left out of the question. It may be suggested, however, that a certain percentage of the better-class oak soils in England should be confined to the growth of this species as, e.g., in the Forest of Dean, High Meadow Woods, Tintern, etc. England has been famous for its oak throughout the centuries. It is a national tree and it would be a pity to see it disappear from areas which have known it for so long. Beech will probably be more largely used in the future to form a lower storey in woods of light-demanding coniferous species.

If therefore we confine ourselves here to the coniferous species we may restrict ourselves to those of whose commercial utility in this country there is no doubt, to wit-Tyrolese Larch, Scots Pine, Common Spruce, and Austrian Pine, to which we may add, with less certainty, Douglas, Sitka Spruce, and Japanese Larch.

This little work is not intended to be a manual of forestry, but a brief note may be given on planting methods and the difference in cost of such. ${ }^{1}$ Expert opinion is probably unanimous on the point that the planting methods in force in Britain in the past and even now amongst the older generation of foresters,

1 I have added the following note as the result of a criticism made by a friend interested in planting who had read my MSS., on the absence of all mention of planting methods and their relative costs. 
PL. 9.

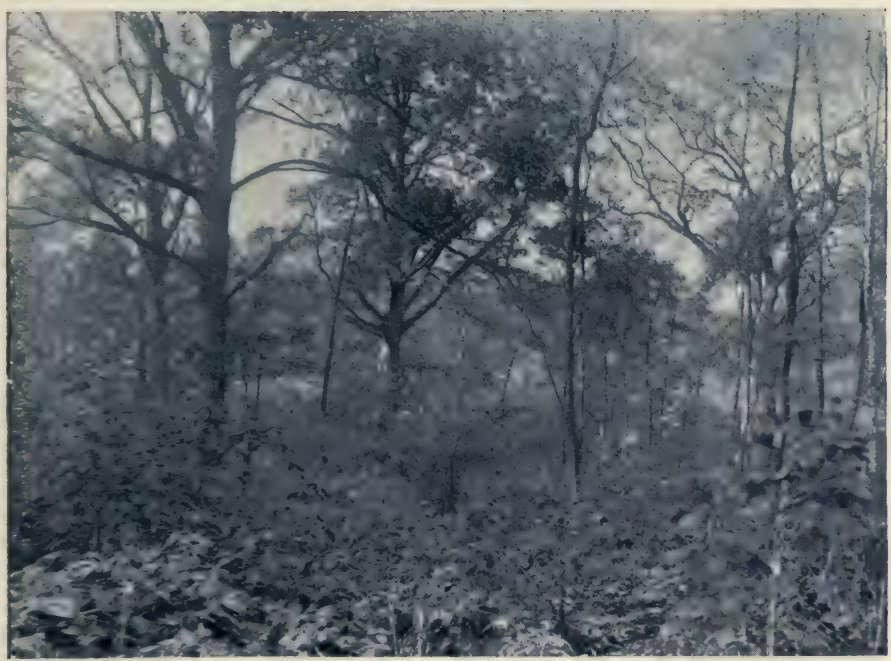

Young Oak Natural Regeneration Under Oak, etc., Overwood, Queex's I'ood, Frith Park, Surrey, October igiz. W. P. D. Stebbing, photo.

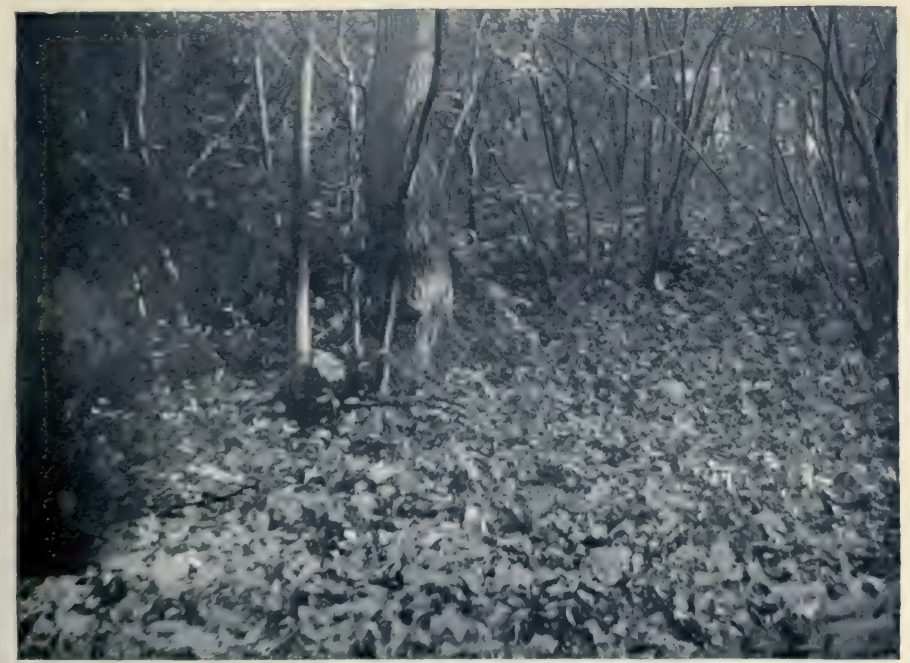

Young Natural Oak Seedlings One Year Old Under Underwood, Queen's Wood, Frith Park, Surrey, October igi2. W. P. D. Stebbing, photo. 

that is planting by the notch system, have had at least as much to do with the subsequent poor development of the crops and the catastrophic windfalls (which have been the usual results of bad storms in the past) as either the soil, species used, or other local factors. Of course the haphazard methods of felling and planting, with no reference to wind and the direction of the prevailing storms, under which woods, which have grown up in the shelter of neighbouring ones, are suddenly exposed by the removal of the latter, are also a fruitful source of windfalls.

The plantations will be mostly formed artificially, i.e. by planting in the plants, although there is no doubt that in some parts of the country woods under proper scientific management could be obtained by natural regeneration (vide Plate 9). Artificial planting is usually done by one of four methods: (a) Dibbling, (b) Notching, (c) Pit planting, and $(d)$ Mattock planting; and tools of a varying nature are used for the purpose.

(a) Dibbling.-This method can only be adopted for very small plants which have not as yet produced strong side roots. A peg or dibbling iron is pressed into the soil and moved backwards and forwards in one plane to make a wedge-shaped hole in which the plant is inserted, the peg then being pushed into the soil at an angle a few inches away, and levered up so as to force the wedge-shaped mass of soil thus disturbed into the hole occupied by the roots of the plant, which thus becomes filled up. The peg is then withdrawn, the empty hole filled up by pushing the soil into it with the boot or peg, and a fresh plant put in at the planting distance. 
(b) Notcking.-Notching with the heavy wedgeshaped spades which may be regarded as glorified dibbling pegs or irons is undertaken in a similar fashion to that already described above. A larger wedge-shaped hole is made and therefore a larger plant can be made use of ; but even here the plant should not possess large side roots, as these will be doubled up against the walls of the hole and arrest the development of the young tree and of its root system.

The common notch planting in force throughout this country is done, however, with an ordinary spade. Conifers up to four years of age are " notched in " by methods which only differ in the shape of the notch, and are one and all equally pernicious. The methods are as follows: The common spade is used to make a notch in the ground of one or other of the following shapes:

$T_{A}^{B}$ notch.-The spade is inserted perpendicularly first at $A$ and then at $B$; the blade is kept in at $\mathrm{B}$ and the handle pressed downwards so as to raise the turf, with the result that A opens out. The plant is then inserted in the opening at the top of the blade of the spade and slipped along until it reaches the foot of the T. The spade is then removed, the turf being pressed down with the foot so as to close up again in a natural manner.

Double $T$ notch. In this the vertical limb of the $T$ is divided into two by another horizontal cut. In other respects the method is the same as the one already described.

$H$ notch.-This is only a modification of the $T$ notch. 
$L$ notch.-Is similar to the $T$ notch, except that an $\mathrm{L}$ is formed instead of a $\mathrm{T}$.

The $T$ notch system and its modifications are cheap and quick, but destroy the root system of the plants, which are necessarily bent to one side with the roots knotted into a ball. Plants put in in this fashion are greatly checked in their growth and may on poor soils show scarcely any height growth or development for several years after planting. They are also much more susceptible to wind damage (this latter danger increasing instead of decreasing with the growth in height and age of tree), insects and fungi. The system and its modifications are probably one of the chief causes of the heavy windfall damage experienced in these islands and especially in Scotland. As will be shown in a comparison of first costs of planting work, it is at least not cheaper than one of the forms of pit planting. It has therefore nothing to recommend it and should be discontinued.

(c) Pit Planting.-This method is adapted to plants of all sizes. The tools which may be used for the work are the common spade, cylindrical spade, semi-circular and semi-conical spades, trowel, and the spiral spade. The object of pit planting is to place the plant in an enlarged hole or pit with its root system in a natural position. The various methods in force fulfil these conditions.

The common spade, and various modifications in the shape of the tool, is used to make a hole of sufficient size to take the roots of the plant either naked or with a ball of earth. The hole should be made of the same width at the bottom as at the top in order that the 
roots may have room to hang freely when held in the hole, and not be twisted up at the bottom. This hole will ordinarily be about 2 feet square and 2 feet deep. The turfs cut off the surface should be placed to one side of the hole, and the finer soil from the top below the turfs be also set by itself to one side. This soil is first filled in upon the roots when the plant is held in position in the hole, the poorer soil being added on top of this till the hole is full. The plant is then pulled up to a position slightly higher than it will occupy when the operation of planting is complete. This raising of the plant draws out the roots so that they occupy a natural position in the pit. The planter holding the plant firmly in his hands then presses down the soil all round with his feet, thus lowering the plant to its proper position, adds the remaining soil and presses this and places the top turf, cut into two pieces, on the surface of the filled-in hole on either side of the plant, if the surface vegetation is not of a rough character. Should it be so the turf is left off. If the pits are made some time before planting the rotten turf is placed in it. The plant is held in the hole before planting by a boy or by the plant-holder.

The cylindrical, semi-circular and semi-conical spades. - Planting by means of these spades is very similar to the methods employed with the common spades. The holes are made with the spades, the plant held in position, and the earth filled in with a trowel. The size of the hole made depends upon the size of the plants.

The semi-circular spade is undoubtedly one of the best tools to use for planting four-year-old conifers, 
especially in old agricultural land which has gone out of cultivation. This method of planting is the only one employed on the Murthly Estate in Perthshire and gives excellent results. It is also used to a certain extent on the neighbouring Scone Estate. The figures of cost for planting with this spade at Murthly are given in a statement of relative costs inserted at the end of this section.

The spiral spade is used to slacken up the soil in the hole. The soil is then taken out with the trowel or other tool, and the plant put in and the soil filled in as already described.

(d) Mattock Planting.-This method consists of a combination of notching and pitting, and is a useful one for planting up stony hillsides. The planting mattock, a tool which is a combination of pick and a mattock, is used, and is infinitely superior to the ordinary pick. A smaller tool like a small half-mattock, the iron portion resembling the flat part of the mattock, is also required. To plant with the mattock : The turf is first pared off the surface with the flattened end of the tool, the pointed end being then used for loosing up the soil. The flattened end then again comes into play, the soil and stones being extracted so far as possible from the hole by means of it ; should the soil be full of bracken roots, and so on, the flattened end is also used to break up these and remove them. The turf and stones may be placed on the lower edge of the hole (on a hillside) to serve as a trap for snow and water.

The plant may be notched in to the hole with the spade or preferably be planted by means of the small 
tool described above, which is used to draw the remainder of the soil from the hole. The plant is then placed in the soil and the tool used to fill in the soil on to the roots.

As regards the above methods spade planting is costly ; the semi-circular spade gives equally good results and is far less costly. Mattock planting is confined to stony ground for which the spades are unserviceable.

\section{Relative Costs of Planting ${ }^{1}$}

Cost per 1,000 plants for labour alone in the first planting. Daily labour wage per day of ro hours: For a man $3 s .6 d$. per day; a boy is. $8 d$. per day.

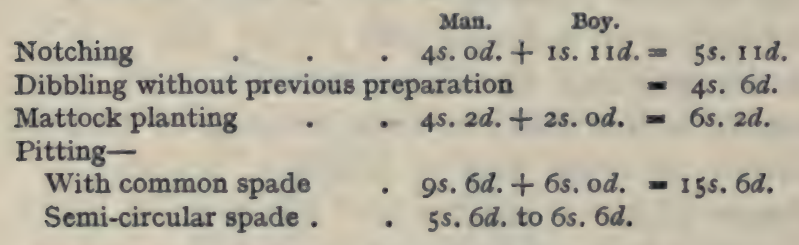

\section{LABOUR REQUIRED}

\begin{tabular}{|c|c|c|}
\hline otching & & $I \operatorname{man}$ or $I$ man and I boy. \\
\hline Dibbling & & I man or I man and I boy. \\
\hline Mattock planting & & I man and 1 boy or 2 men. \\
\hline Spade planting . & & $\begin{array}{l}\text { I man and I boy or, less } \\
\text { quickly, I man and the } \\
\text { plant-holder. }\end{array}$ \\
\hline Semi-circular spac & . & $\begin{array}{l}2 \text { men and } 3 \text { planters work } \\
\text { as a squad together. This } \\
\text { has been found the best } \\
\text { number for a squad at } \\
\text { Murthly. }\end{array}$ \\
\hline
\end{tabular}

1 The figures here given are those in force in parts of Perthshire. They are based on practical experience and were obtained for me by Mr. J. M. Murray, B.Sc., Assistant in the Department of Forestry, University of Edinburgh. 


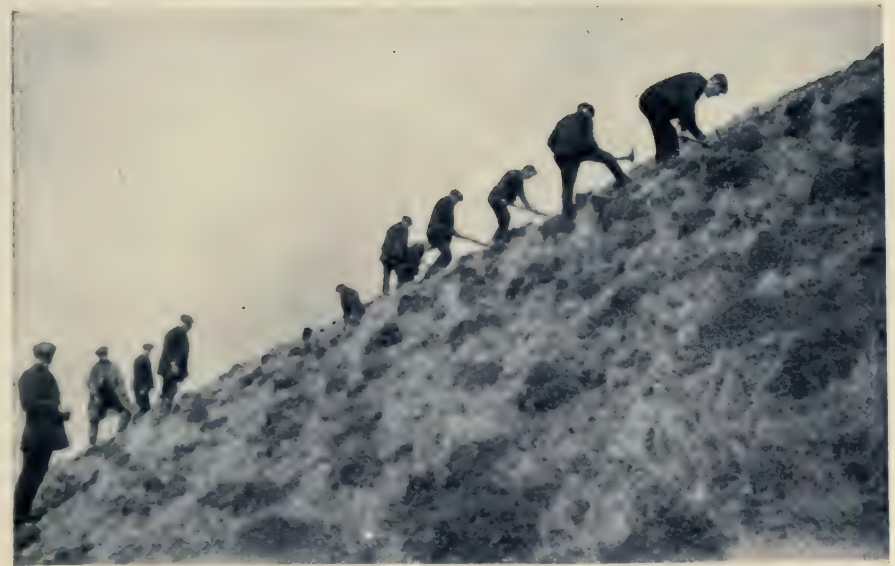

Mattock Planting, Talla Catchment Area, April igi4. The squad of men ahead are preparing the holes whilst those behind are putting in the plants.

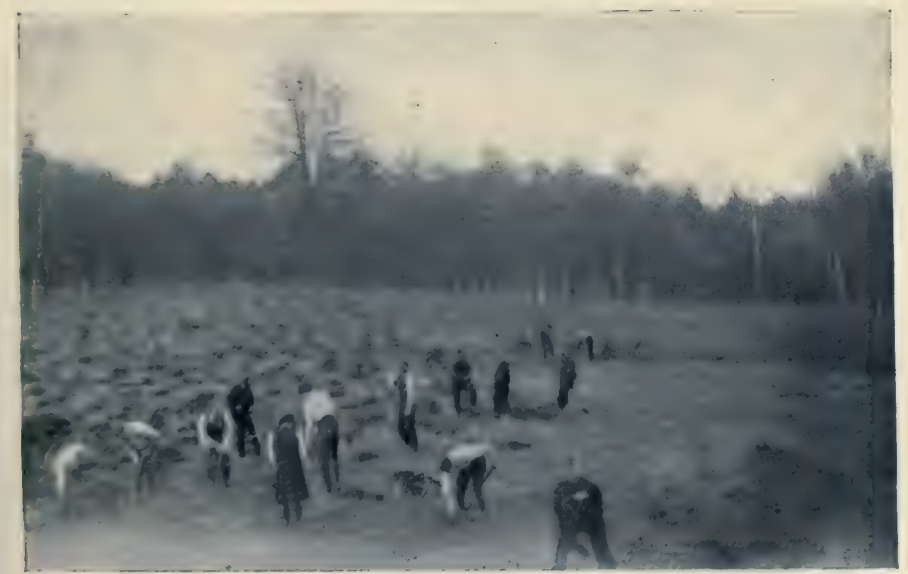

Pit Planting.

Edinburgh University students digging pits into which four-year-old Douglas are to be planted, Craig Vivian, near Dunkeld, Perthshire, March 19r4. Photos by Author. 

The following has been done at Murthly, with welltrained men using the semi-circular spade $:^{1}$

Two men make 2,400 holes per day of to hours.

Three planters (boys) put in 2,400 plants per day of ro hours. Therefore total cost for 2,400 plants $=12 s$.

On very free soil one man can make I,000 holes a day and together with the planter will put in $I, 000$ plants. The man making the holes finishes the $I, 000$ soonest, and then helps the planter with the remainder of the I,000 plants which are also finished in the day.

The total cost in this case comes to $5 s .2 d$. or cheaper than notching.

1 Mr. A. Murray, Chief Forester, Murthly, also gives me the following illustration: On Kingswood Moor, Murthly, two years ago we averaged about 900 per man per day of 8 to Io hours and this may safely be taken as a fair average. 


\section{V \\ AFFORESTATION AND LABOUR}

IN previous articles the question of the labour supply has been touched upon. The war has brought about such a complete change in labour problems generally that old-time ideas upon this subject are now antiquated shibboleths. The whole question of employment and labour is undergoing revision in our minds, slow it may be, but still revision. And perhaps in no direction is this revision of pre-war ideas more prominent than in the question of the employment of women on the land. It is for this reason that I have included in this book articles I have published on this subject with reference to the employment of women in forestry. It has been pointed out to me that these articles, if left without their complement, may seem to give an undue prominence to this question and seem to convey an idea that forestry work and operations could be chiefly undertaken by women. This is far from my meaning. Forestry is pre-eminently a man's work -necessitating as it does in all its varying branches an open-air life and considerable exposure, in fact, a life of "roughing it." For this very reason it proves an ideal existence for those of good physique who are at the same time lovers of nature in some of its finest 
phases. The main difficulty in the past has been to obtain sufficient labour in the woods. Or perhaps it may be better expressed by saying that sufficient labour has not been utilised in the woods. Woods-commercially grown woods-require constant supervision. It is not sufficient to plant them and then go away and leave them to shift for themselves up to such period as it may be possible to make a thinning in them which will prove saleable. These old-time methods, combined with others, have brought us to our present position. If we are to maintain in the future that area of woods which our requirements have shown us should in the interests of national economy and safety be kept up in this country, and if we are to make them pay, they will have to be grown properly and given constant attention. For this work both men and women can be employed, in their several departments, with advantage. We are only concerned here with the employment of men.

One of the results of the war will be the necessity of providing work for partially incapacitated soldiers and sailors. They could be utilised in a certain amount of the light forestry work which does not require the services of able-bodied men.

There will also be the question of employment for the numbers of young men who, leaving their former sedentary occupations, have gone out to fight for the country. On their return these young men are likely to look with distaste at thejr former work. They will ask for a more active life. If that life cannot be provided for them in this country they will emigrate. And yet, if a campaign to plant up our waste lands, the 
present position of which is economically a disgrace to the nation, and one very far removed from the thrift and conservation and rehabilitation of the national resources which is now being so strongly advocated-if, I submit, a campaign of sufficient magnitude is undertaken to plant up these derelict acres which could grow so much of what we want, we should be able to provide employment for these young men; as also for our partially incapacitated soldiers and sailors.

One of the reasons why the recommendations of the Coast Erosion Commission were not acted upon was said to be the impossibility of employing the townsman in planting work owing to his inability to stand the strain and exposure of working on the soil, and his ignorance of the use of the spade and pick. That this was a fallacy the war has proved. Modern warfare entails the constant use of both these implements. In fact, they are probably used as much as the rifle, if not more so. The men of the towns have stood their training in the use of these tools, and numbers of youngsters, having a thorough acquaintance with them, and also hardened to exposure, should be available for afforestation work.

Without undue optimism it may be considered then that a large planting scheme should no longer present any difficulties on the score of labour once the war has come to an end-in fact, the drafting of men willing to take on such work into one or more Planting Corps when the disbandment takes place at the peace will provide one source of employment for the men who gave up their jobs to join the armies which would 
PL. II.

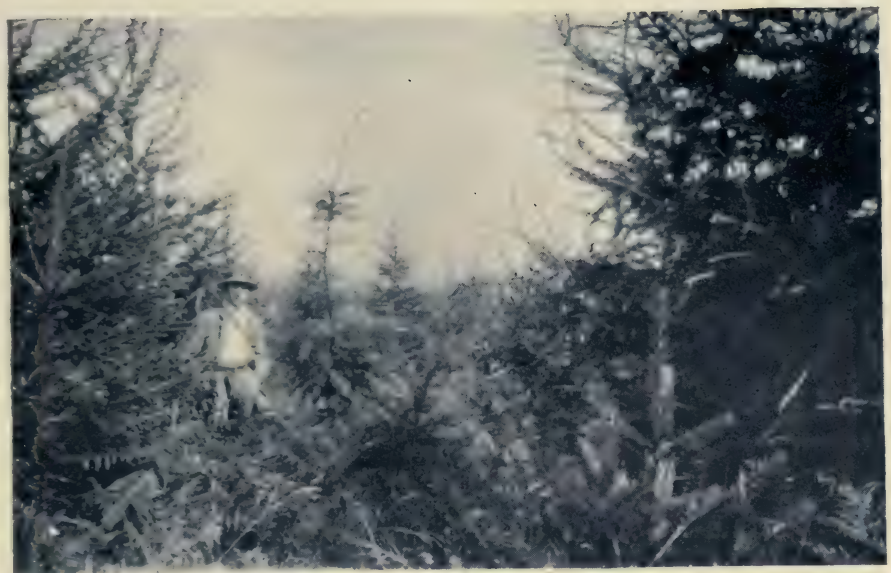

I.arch Ixterplanted with Douglas, Rohallion Plantation, Murthly, Perthshire, August i9i3.

The larch were given a three years' start.

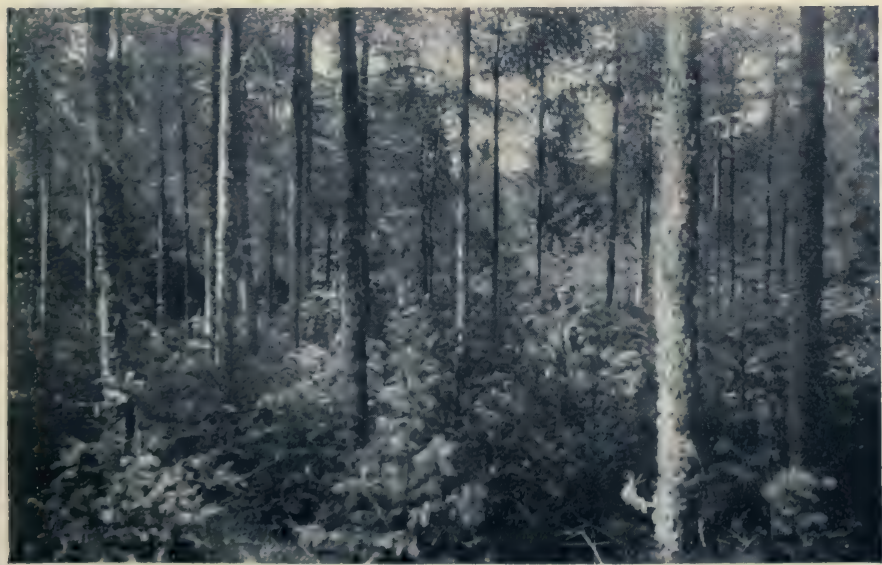

Larch Uxderplanted with Douglas, Novar, Ross-Shire, June igi2.

Douglas five-year-old. I,arch 28 -year-old. The larch were attacked hy larch canker and heavily thinned before being underplanted. Photos by Author. 

prove most serviceable to the country. But to enable such corps to be immediately formed, without that inevitable friction and delay which is so apt to ruin schemes of this nature, a cut-and-dried plan should be drawn up beforehand ready to be at once put into force when the moment arrives, and this plan should be on a sufficient scale to ensure the adequate realisation of the objects aimed at.

As regards education and training. It has been shown that every soldier nowadays knows how to use the spade and pick. Therefore with supervision there should be no difficulty in getting the planting work done satisfactorily. The education in forestry of those who elect to take to a forestry life should also present no difficulties. There are forestry classes for woodmen in the Agricultural Colleges throughout the country and there is an excellent Woodmen's School at the Forest of Dean, a fine new building, up-to-date in all respects, having been completed just before the outbreak of the war. Selected men from the Planting Corps could be sent to these schools in the summer season when forestry work is slack to take the woodman's courses. In this way a trained subordinate forest staff would be built up ready for employment in the supervision of the large areas of commercial woods which the country would possess.

The higher training for the gazetted ranks who would be responsible for the scientific management of the woods on strictly commercial lines likewise offers no difficulties. Many of the most important Universities of the country now possess Forestry Departments in which students, as the result of a three years' course, 
take either a degree of B.Sc. in Forestry or a diploma in Forestry.

These men would proceed to the woods in the first instance as assistants to the officers in charge of the different areas, ultimately looking to obtaining a charge themselves when they possess sufficient practical knowledge of the work. In this direction therefore a career presents itself for young officers who at the close of the war will wish to follow a life which will have plenty of the open air about it with a minimum of the office stool.

The courses for the Forestry Degree given by the University of Edinburgh are fully described in Article XVII (p. 249) under " Employment of Women in Forestry " and need not be recapitulated here.

As one who has had plenty of experience of the glorious "freeness," combined with the considerable responsibility, of a forester's life, the writer can assure all those who wish to, comparatively speaking, remain their own masters and live in the open air that there are few occupations to rival it. 


\section{PART II}

\section{BRITISH TIMBER SUPPLIES AND THE FORESTS OF RUSSIA}

\section{VI}

TIMBER SUPPLIES AND FAMINE PRICES

WHAT are we going to do about timber supplies both in the near future and a more distant one?

This is one of the war problems which has received but little attention until quite recently. We have so long been accustomed to get all the timber we required without trouble that we had come to forget that it was practically all imports and that we grew but little of the timber of commerce ourselves. And yet, as will be shown, this material has come to be one of the necessities of the warfare of the present day.

In obtaining the supplies we have required we cannot even be said to have " muddled along " satisfactorily, for we are simply living a hand-to-mouth existence; have been doing so for months; and it is proving a most costly experience. And there is every probability of the position assuming a graver complexion. It has been recently asserted by a prominent expert in the timber trade that if the present demand 


\section{TIMBER SUPPLIES AND FAMINE PRICES}

continues a timber famine in this country may be expected. We do not know what this may mean. We have never experienced such a thing. It is doubtful whether the world has ever seen a famine of this nature. On what is the assertion based and what are the steps which should be taken to avert such a calamity? Prices, we all know, are preposterously high. What can be done to bring them down to a more normal level ?

Before the outbreak of war there had been a considerable stringency in the timber market, and at the beginning of August I9I4 the prospects of the market in this country were most gloomy. For two or three years antecedent to this date difficulty had been experienced in obtaining loans, and as a consequence the house building trade was in a depressed state.

Then came the war and with it a quite novel demand for timber materials from an unexpected quarter, viz. the Admiralty and War Office. Hutting accommodation, timber and props for trench construction, railway sleepers, barbed wire entanglements, waggons, entrenching tools, and so on were all required on a large scale and at short notice. Within a very short time it was discovered that the stocks of timber in this country were quite inadequate to supply the demands. Our chief source of supply, our Ally Russia, who sent us before the war about half of our imported European timber materials, to a great extent failed us at a very early stage, since the exports from Petrograd, Riga, and the Finnish ports were closed. As is well known, this closure, with the stoppage of fellings in the French pitwood areas, at once reacted on the pitwood supplies in 
this country, and the collieries were faced with a difficult problem during the earliest days of the war.

Of course this could not have been foreseen and the Cabinet had its hands very full at that period. The mine-owners to a great extent had to settle the matter for themselves. The English Board of Agriculture issued within a few months a pamphlet which was of considerable assistance. It might have been anticipated, however, that the pinch which was at once felt on the score of pitwood would have opened our eyes to the other directions in which a shortage was likely to make itself felt. We had been too long spoon-fed, however, and the reverse was the case. No efforts were at once initiated to place the whole matter of the timber supplies of the country on a firm basis under a central and business-like control. Different interests competed the one against the other, and in this laisser faire policy the most powerful, because backed by unlimited funds, were the Admiralty and War Office. Orders were placed right and left and prices were of little account. These prices, with the dearth of freight steamers, added to the later activities of German submarines, jumped up and continued to do so. In the haphazard manner in which the whole business was approached there was nothing to prevent merchants from asking what price they pleased. True the Government put on an adviser, paying him an enormous commission. But he was in the trade himself! The Swedish merchants who, with the closing of the Russian ports, were quick to perceive their opportunity, took full advantage of our predicament. Prices went higher and higher until they now stand at two and a half to 


\section{TIMBER SUPPLIES AND FAMINE PRICES}

three, and even more, times the ordinary pre-war figures. Millions of pounds sterling must have been thrown away in the purchase of timber, the ordinary common timbers of everyday use, which could certainly have been saved had matters been placed on a business footing. It is useless to cry over spilt milk, but had the matter been entrusted to a man, not connected with the trade, who understood the princiciples of scientific forest management and had himself been in charge of large areas of State forest, very different results would have been obtained.

And we are in no better case at the present moment. The Home Timber Supply Committee has been already alluded to. Its chief raison d'etre is to obtain supplies of timber for the Government needs. It is doubtful whether it will be able to do much to stay unnecessary fellings made to take advantage of a high market. And in any event it has no hold over timber merchants -no more than Government can exercise at present any control over the market and prices. Nor do these fellings affect the matter, for the amounts of timber available in this country are so small that their influence on the market so far as the future is concerned is insignificant. Far bigger issues are at stake than can be settled by the comparatively small area of woods, practically all privately owned, standing in Britain. In the meantime the home timber trade is doing well. Proprietors have offered their woods freely and they have been as quickly taken up by the home merchants and also by colliery proprietors. In fact these latter were on the scene, as has been stated, very early in the war days, for they were compelled to turn to home-grown wood, 
rough and heavy as it was, since the foreign pitwood market was failing them. A remarkable feature of this home trade has been the demand for ash. In England five to six times the amount of ash (numbers of trees) has been sold in the past year than in any previous year and the price has risen from Is, $6 d$. to $3 s$. (and even as high as 4 s.) per cubic foot for the trees standing in situ.

The wood of this tree has been largely used by the naval and military authorities for all sorts of transport appliances. In the Lake district and elsewhere the wood has been fashioned in the local saw mills into handles for entrenching tools and grenades.

In the Board of Agriculture and Fisheries Report "On the Supplies of Home-Grown Pitwood" above referred to, which was issued on November 30, I9I4, the following extract indicates the position of affairs in this connection in this country at that date based on a careful estimate made by the Board's officers :

"Assuming the volume of " extraordinary 'fellings" ("emergency fellings" would perhaps have been a better term ) "to be the same per acre in Scotland as in England (and it is probably considerably greater) there would be approximately I, 600,000 tons of pitwood; possibly $2,500,000$ tons would be a better estimate. If the volume of the 'extraordinary' fellings for England and Wales, viz. 3,410,000, be added to this amount, a total of nearly $6,000,000$ tons is reached, and it is a fair assumption that the addition of supplies from Ireland would give a total equal to one and a half years' total consumption for the collieries. It would appear, therefore, that the position, while it requires rational handling, is by no means disconcerting.' 
It was thought at the time that the war would be over by the following summer. The comfortable assurance of November I9I4 has quite another aspect in May I9I6.

That home timber can be made to, in some small degree, supplement even temporarily the great scarcity is of importance and value, but it will not help the nation at large to face the position at the end of the war and a more distant future.

This is the much larger question before us. Suppose that the war lasts another year, or even longer. What is going to be done about the timber supplies? Are the Allies-is this country going to make no effort to place the matter on a basis which will at least give some stability to prices and prevent the wasteful, the criminally wasteful, extravagance of the past twenty months.

At the beginning of the past season the bulk of the timber supplies for war purposes was procured from the port of Archangel, but where future supplies are to come from appears to be a grave problem in the eyes of prominent timber merchants. It is said that there will not be sufficient supplies from Archangel to meet the demand. Should Germany succeed in restricting the shipments from Sweden or manage to torpedo the boats carrying timber cargoes, it is probable that there will be something of a timber famine in this country provided the present demand is maintained. And as long as the war continues there is no guarantee that the demand and prices will not remain at a high level.

The Home Timber Committee will see that we get all that is possible from home woods. But the Board 
of Agriculture Report fairly indicates the limitations in this direction. They will not meet the demand.

Three points present themselves for serious consideration: (I) Freights, (2) Other sources of supply, (3) Prices.

(I) Freights.-At the beginning of last season, as we have seen, the bulk of the supplies for war purposes were procured from Archangel. Freights were supposed to open at about $60 s$. to $70 s$. per standard ( 165 cubic feet), but shippers, realising the scarcity there would be in tonnage, held out for 80 s. to gos. which was gradually increased until it reached the figure of E9 Ios. per standard in November I9I5, as against 30s. to 45s. in pre-war times. Even in September I9I4 the highest freight paid to this country would not exceed $65 s$. per standard, which was considered a high rate.

Much could have been done at that time had Government been wide-awake enough to have placed the matter on a business-like footing. Last September shippers were ready to pay $£ 8$ I5s. to $£ 9$ Ios. and even $£$ Io for ship room. In February I9I6 shippers were quoting for the present season at $£$ Io per standard from Archangel to this country. Last spring (I9I5) battens were $f I I$ per standard f.o.b. They had to carry a $£ 9$ Ios. freight with in addition about 30 s. insurance, freight and insurance being equal in value to the f.o.b. article! The trade remarked that the like has never been known before from the Baltic and White Sea ports!

That some one has blundered, and blundered badly, is only too obvious. We are simply throwing away good money owing to our complete ignorance as a 


\section{TIMBER SUPPLIES AND FAMINE PRICES}

nation of everything connected with forestry - what it means, what it supplies, and how these supplies are marketed.

The question of the want of vessels for freight purposes has been receiving considerable attention in the Press and need not be entered into here. That vessels are required and will have to be made available for the carriage of certain classes of timber to this country appears now to be a matter of considerable urgency.

We can do without mahogany and other foreign valuable timbers. We need not import oak or elm, etc., which can be obtained from our own woods. It is the coniferous timber--pines and spruces-which will be required in large amounts.

(2) Other Sources of Supply.-Are we envisaging this question in the most economic fashion in depending upon neutrals for our supplies? The trade say that if the demand continues on past lines we cannot obtain sufficient supplies from Archangel. Since we took no steps at the commencement of the war to ensure supplies from other Russian ports, this is more than probable. Of neutrals Sweden has taken advantage of the high prices to send us timber, but she is a doubtful supplier for several reasons which are well known. America, and our own people in Canada and Newfoundland, have greatly benefited by the great rise in prices and huge quantities of timber have been imported from these countries. This is satisfactory for the present. We should have been hard put to it without them. But it must be remembered that they are coming in, to a considerable extent, as the result 
of the ruincus rates in force. With a fall in prices, which, in the interest of national economy, must be brought about in one way or another, can we depend on these supplies reaching us ? And in any event for how many years could they be maintained? It is well known also that Canadian and American spruce is not in as much favour with the trade as the Baltic material, as the former is soft and mild (probably owing to its quicker-grown character) and is by no means as durable as the close-grained article from the Baltic and White Sea. And even if the material were as good we should be chiefly concerned to lower the prices in force, and that cannot be done by making one of our chief sources of supply in countries several thousand miles distant, and which moreover have already in past years cut out much of the timber accessible at ordinary market rates to these islands.

The problem before us is to obtain a definite source of supply at a reasonable rate. Having achieved this, the present ruinous market prices will drop to a more normal level. Some increase, of course, must be expected but not the present famine rates, which should never have been incurred.

In peace times our main source of supply in Europe was Russia, more than half our European imports coming from that country. This one fact, had it been realised early in the war, might have opened our eyes. Russia is our ally. Russia has enormous tracts of unexhausted forests. Russia has a huge population. A year ago it would have been possible to make arrangements in Russia which would have resultedand this is not written at random-arrangements could 


\section{TIMBER SUPPLIES AND FAMINE PRICES}

have been made which would have resulted in the saving of large sums of money to this country. We should not have had to pay in cash, in gold, for this Russian timber. It could have been set against the equipment, shells, etc., which Russia has received from the Allies and the matter would have been subsequently adjusted. Instead we have preferred to pay out gold into the pockets of neutrals. And yet we are urgently called upon by the Government to restrict all imports ! Presumably imports from neutrals chiefly.

The timber industry has proved a necessary part of the provision required for the furtherance of the war. The problem, commencing with the mines, has been acute from the start. It is still more acute to-day, and in order to guarantee supplies and to put an end to the hand-to-mouth policy, it has become essential, if we are to stop the present appalling extravagance in the nation's timber bill, to face this urgent problem and make arrangements which will increase our timber supplies in the future. This problem is considered in the next article.

(3) Prices.-Prices since the commencement of the war have been entirely influenced by the action or want of action on the part of the Allies in this timber matter. It is imperative that the ridiculous prices now being paid by our Government and by ourselves (for the public has been hit badly in this matter, as the family household knows), for our essential requirements in timber, should cease at as early a date as possible.

The following table shows the present rates being paid for home timber materials as compared with prewar prices. The table was prepared in February I9I6 : 
Pre-War Prices Compared with Present Prices

Pre-War Rates per Cubic Foot

TIMBER

Larch

Scots Pine

Spruce : . $4 d .-6 d$.

Oak . . $1 / 3-1 / 6$

Ash

Elm

$\mathrm{I} / 6$

Birch (bobbin wood) 26/- ton DD Beech (rough, bobbin. wood)

$24 /-, ;$, (clean)

Sycamore (rollers bobbins) : 28/-ton.

Sycamore (large timber) . . 2/6-5/-

\section{COLLIERY WOOD}

Pitwood per soo lineal feet DD. Pit Props:

Scots Pine ( $3^{\prime \prime}$ top diam.) $4 / 6$ " $"\left(4^{\prime \prime}, ",\right) 6 /-$ " $"(5 ", ", n) \quad 9 /-$ " " (6", ,, $12 /-$ Larch - $\left(3^{\prime \prime},, \quad,\right)-$ " . (4" , " $18 /-$ ". (5" ", , $26 /-$ ". (6" ", ",) $32 /-$ Oak Scrub

Pit Sleepers, per 100 :

$$
\begin{array}{lll}
\left(3^{\prime} \times 5^{\prime \prime} \times 2^{\prime \prime}\right) & : & 12 / 6 \\
\left(3^{\prime} 6^{\prime \prime} \times 5^{\prime \prime} \times 2^{\prime \prime}\right) & : & 14 / 9 \\
\left(3^{\prime} 9^{\prime \prime} \times 5^{\prime \prime} \times 2^{\prime \prime}\right) & : & 18 /-
\end{array}
$$

Rathay Sleepers

\section{Present Rates per Cubic Foot}

\section{TIMBER}

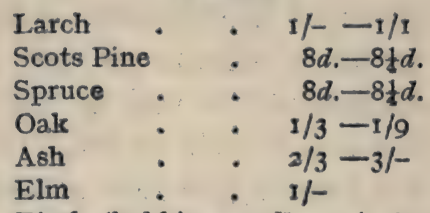

Birch (bobbin wood) 10/- ton Beech (rough, bobbin) 10/- ," ,, (clean) . 1/2

Sycamore (rollers bobbins) $\quad 28 /-$ ton Sycamore (large timber) . $: 2 / 6-5 /-$

\section{COLlizRy WOOD}

Pitwood per soo lineal feet $D D$. Pit Props :

Scots Pine ( 3 " top diam.) $16 / 6$

$$
\begin{aligned}
& \text { " " (4" ", ") } 22 / 6 \\
& \text { " " (5" , , } 28 / 6 \\
& \text {, " (6" , " , ) } 33 / 6 \\
& \text { Larch . }\left(3^{\prime \prime},,,\right) 16 / 6 \\
& \text { " . (4" ", ", } 22 / 6 \\
& \text { " . (5" ", ", } 32 /- \\
& \text { " . }\left(6^{\prime \prime}, \text {," } 38 /-\right.
\end{aligned}
$$

Oak Scrub per ton delivered on railway loaded in trucks . . $18 /-$ Pit Sleepers, per 100 :

$$
\begin{array}{lll}
\left(3^{\prime} \times 5^{\prime \prime} \times 2^{\prime \prime}\right) & : & 26 /- \\
\left(3^{\prime} 6^{\prime \prime} \times 5^{\prime \prime} \times 2^{\prime \prime}\right) & : & 31 /- \\
\left(3^{\prime} 9^{\prime \prime} \times 5^{\prime \prime} \times 2^{\prime \prime}\right) & : & 36 /-
\end{array}
$$

\section{RaIlway Sleepers}


Comment on the above figures is scarcely necessary. They are a direct outcome of two facts-the first, an almost total lack of interest on the part of the nation as a whole in all pertaining to the economic questions involved in commercial forestry and the maintenance in these islands of that acreage of woods managed commercially which our population and industries demand; and, secondly, to the failure on the part of the Governments of the past fifty yars, to go back no farther, to realise the position in this respect which would confront the nation in the event of just such a European conflagration as has taken place. The Government existing in this country 250 years ago was more clear-sighed. True, it may be said that out "wooden walls" of that day and the necessity for maintaining them were factors which both Government and the public could more easily grasp. But no Government of the present day would care to shelter itself behind such a plea. Our economic needs in timber are far greater now. We have only to look at the gigantic imports-they rose by $£ 12,000,000$ in the four years from 1909 to I9I3-to realise this. The next four articles are devoted to pointing out the manner in which it should prove possible to bring down these prices and to ensure our timber supplies in the future. 


\section{VII}

BRITISH TIMBER SUPPLIES AND RUSSIAN FORESTS

In previous articles brief allusions have been made to the forests of Russia, the very considerable importance they have enjoyed in the past in the European timber markets, and the immensely larger influence they are likely to exert in the future. The question is one of very serious moment to this nation. How serious and how important it is the aim of this and succeeding articles to demonstrate.

It has been already mentioned that our timber, etc., imports increased by $£ 12,000,000$ between 1909 and I9I3. ${ }^{1}$

A more significant factor than even the rapid increase in the imports is the fact that 67 per cent. of them came from European countries, chiefly Russia, Sweden, and Norway. France sent us annually considerable amounts of pit props for the collieries, the cutting off of which supply so seriously hampered us during the first few months of the war. The produce from the other European countries is negligible for our present purpose.

The Board of Trade Returns show that Russia sent us about $£ \mathbf{1 5 , 0 0 0 , 0 0 0}$ of timber and other products during r9r3, or approximately 35 per cent. of our whole

1 This subject is fully dealt with in Article XII. 


\section{TIMBER SUPPLIES AND RUSSIAN FORESTS}

imports. The materials sent were chiefly conifer logs, dressed and undressed timber, pit props and pitwood, wood manufacures and smaller amounts of wood pulp, oak logs, tar, pitch, and oil of turpentine.

How is the war going to affect our timber supplies from Russia? We need not consider the amounts at present coming in. We are all aware of the various reasons for the shortage. It is the position as it will arise at the end of the war, and for some years subsequently, that requires our most careful consideration.

Can we hope that conditions at the end of the war will be the same as before its outbreak ? That Russia will be in a position to send us the same or increasing amounts of forest materials? Will the markets be in the same condition? Their present position with the great upheaval of pre-war conditions which we are witnessing can scarcely lead us to form so optimistic an opinion.

What then should be the policy of this country?

So far as the past and recent trend of events in this matter enables a judgment to be formed, it would appear (and the statement also applies, though perhaps to a smaller extent, to our Allies) that there are two clear and separate issues upon which a decision should be arrived at in this timber supply problem.

(I) The arrangements to be made to cope with the position which will face ourselves and our Allies at the end of the war.

(2) An arrangement under which our timber supplies during the next forty to fifty years may be ensured.

As introductory to a detailed description of the forests of Russia, both in Europe, Finland, and 
Siberia, our position under these two distinct counts should be clearly understood; so far, that is, as it can be estimated from data collected on the resources of the existing forests of the world from which the timber markets have been drawing their supplies in the past.

The present position of the timber market is admittedly abnormal. In the last article the prices existing in February I9I6 were contrasted with the market rates in force just previous to the outbreak of war. It has also been shown that we are now committed to a policy of felling in our own woods which probably will leave us with little of commercial value at the close of the war.

It becomes apparent then that the urgent points for consideration now before the nation are those embodied in the two heads above stated. That we should make such arrangements as shall ensure supplies of an adequate nature becoming available as soon as the war ends, or as soon as the trend of the fighting shall have opened ports now closed, in order to supply in the cheapest manner the enormous demand which will exist; and secondly, that such steps shall be taken as shall ensure our needs in timber, pit props and wood pulp, etc., being satisfied at reasonable rates during the next forty to fifty years.

(I) The arrangements to be made to cope with the position which will face ourselves and our Allies at the end of the war.-Where are we and our Allies going to look for the large supplies of timber, etc., which will be required at the close of the war? The present high prices and the large demand for materials which 


\section{TIMBER SÜPPLIES AND RUSSİAN FORESTS}

will be required for rebuilding the devastated areas have been already alluded to. Is the end of the war going to witness a ruinous competition between the allied countries in the timber markets of Europe ? And are colossal sums to be spent, colossal fortunes to be made, in rebuilding the houses, etc., in the areas destroyed by war?

It is difficult to see, unless the Allies come to an early and definite understanding on this head-it is difficult to perceive how matters can be otherwise. When all allowances have been made for America, Canada, and Newfoundland continuing the imports they have been sending us or increasing them, will there be sufficient to meet the enormous demand? And will these latter imports bring down prices. As has been stated elsewhere, a considerable proportion of the amounts reaching us are a direct outcome of the prevalent high prices. To have to continue paying the present exorbitant prices or even prices double pre-war rates will be suicidal and a most unstatesmanlike policy. It cannot be maintained that war time is not the time to consider these matters. If there is one thing certain it is that the termination of the war will be too late. We had not the foresight to grasp what would happen at the outbreak of this colossal war. Let it not be said of us that its termination found us in the same state of unpreparedness.

My proposition is that it will be imperative that the Allies should be in a position to control the European timber market at the end of the war, to exercise in fact a State control over prices for a time, as the only effective means to lessen the enormous 
cost of the reconstruction work which will otherwise result. It is no plea that such a thing has never been done before. The end of the war will find us, the war itself is finding us, doing a good deal we never thought to have to do. First then we want to place our finger on accessible supplies in large quantities and owned by the Allies; and, secondly, to come to an agreement by which these supplies can be made available at the earliest possible moment with the object of bringing down the present preposterous rates.

If we examine the forestry resources of the Allies the one great fact which immediately becomes apparent is the gigantic area of the forests in Russia, the Land of Forests, as it has been called. For some years past I have made some study of the forests of European Russia and also those of Finland and Siberia, and the following three articles serve to indicate to some extent the great value of these forests. It is a most unfortunate thing for this country that we have known so little of Russia in the past, of its enormous possibilities and potentialities and its great value in many ways to this country. Germany discovered it. Russia is honeycombed with Germans and German enterprises, in no wise conducted for the welfare of Russia or in the interests of Russia and her people, but for the furtherance of German Empire objects and of those alone. Even in the matter of forestry imports Germany was undermining our previously unquestioned supremacy in the Russian timber markets. Germany has vast forest resources in her own country, a considerable proportion of which is afforested, and not only afforested but with the woods managed on the highest 


\section{TIMBER SUPPLIES AND RUSSIAN FORESTS}

commercial basis possible. And yet in recent years her imports from Russia have increased rapidly, the increase being greater in proportion than the increase to Great Britain. And she has been importing from elsewhere also. Why ? Was it because she really required the materials, or is the reason to be found in the fact that she has been deliberately storing up her woods, undercutting in them, with a set purpose in view. Did her wonderful organisation for the World War and her deliberate intention to make it as frightful as possible foresee the enormous damage that would be done to towns and the enormous demand which would exist for timber at the close of the war? During the war we know that she has been cutting down the woods in the territory she has occupied and either utilising the materials for trench construction or other purposes or storing them up for the great demand she expects at the peace! We know how Belgium is suffering in this respect. In a recent Foreign Office Memorandum it was stated that in one month from October 26 to November 25, I9I5, the Germans exported from Belgium into Germany by one route alone, amongst other things, $34^{\circ}$ tons of pit props cut from promising young woods.

To return to Russia. From Russia we imported 35 per cent. of our timber supplies in I9r3. In Russia the Allies have for the purpose here considered a source of supply which should fulfil the objects required. Russia in Europe has an area of $447,500,000$ acres of forests, Finland another $62,800,000$ acres, and Siberia and Turkestan the gigantic total of $853,000,000$ acres more. Now much 
of this area in Russia and Finland and Western Siberia produces the very materials which will be required in such enormous quantities at the close of the war. Had we been far-sighted enough, had we shown a tithe of the resource and organising powers of the Germans, we should have long ago arranged for tapping these Russian resources in the event of war on a previously formed plan. But this is in the past.

These enormous areas of Russian forests contain large amounts of unexploited timber. If we take Russia in Europe to commence with. A few years ago it was officially recorded by the Russian forestry authorities that they were cutting far below the possibility, in other words, that the annual increment put on was greater than the volume of timber taken out of the forests. Also that large areas of old woods had almost ceased putting on increment and were going back, i.e. losing their sale value. At that time the Government estimated that the fellings made were something under 50 per cent. of the possibility. Matters have altered somewhat since then. But Russia, with its immense forests, scanty population (in the afforested areas), and want of communications, cannot move quickly in such matters, and there can be little doubt that there is a great margin to work upon. For instance, the larger portion of the State forests are in the north in the Governments of Archangel and Yologda, areas we are most interested in, since much of our imports came from this region. These forests are difficult to work owing to the deficient communications. Consequently only 7 cubic feet of timber per acre were felled out of a prescribed 7 cubic feet 


\section{TIMBER SUPPLIES AND RUSSIAN FORESTS}

per acre or about ro per cent. The averages have been higher more recently but are still a long way below the possibility. We come now to Finland with its long stretch of sea-washed coast-line and its excellent system of internal waterways offering the cheapest and easiest method of transporting timber and other forest produce. A perusal of the article on these forests will show that here also there are large areas of unexploited material of the kinds, Scots pine and spruce, we import so much. The export trade from Finland, although it has made some progress in recent years, is still far from having reached its maximum. On the subject of the State forests figures for 1908 showed that whereas the mean annual increment of wood put on per acre was valued at $2 \mathrm{I}$ cubic feet for the whole country, the total amount sold from the State forests was only 3.4 cubic feet per acre.

Moreover, as a result of a partial enumeration of the growing stock on some areas it was estimated that there were something over $2 \mathrm{I}, 000,000$ trees of approximately Io in. diameter and over at chest height standing in the State forests, and it is considered probable that at least this number, and probably a larger one, also exist in the areas of privately owned forests in the country. On the subject of the gigantic area of forests in Siberia it is very difficult to form an estimate of the amounts of timber they contain, owing to the fact that only about a fourth of the area has been explored by the Forest Department. Want of demand, a sparse population, and absence of communications have preserved these forests so far from the lumberer. Only in the dry steppe region and parts of Turkestan, 
with which we are not concerned here, is there a scarcity of wood. In these Siberian forests, therefore, even in those of which something is known, one would expect to find that the fellings were far below the estimated possibility of the areas. And this is borne out by such figures as are available. For instance, according to estimates framed in I9II it was shown that no less an amount than $I, 800,750,000$ cubic feet of timber were available from the State forests. Of this amount I 7I,500,000 cubic feet only were disposed of, or something under Io per cent. In some forests, viz. in the Government of Enessey, the percentage sold was only 5 . And these figures apply only to such of the areas of State forests as have been explored and organised!

Russia has then these large areas of unexploited accessible forests or forests which can be made accessible by a not very heavy expenditure. She has also a very large population which can be drawn upon to provide labour. Under the existing methods for exploiting this forest wealth there exist throughout the country over 2,000 saw-mills.

How then can this great store of timber be most easily and expeditiously opened out in order to place in the hands of the Allies the large amounts of materials which these areas contain and which will be in such great demand at the close of the war? The difficulties confronting this problem do not appear insuperable. The first necessity would be the provision of funds and the second organisation.

My suggestion is that Russia should be asked by the Allies, by the British Government, if necessary, since we are very deeply concerned in this matter, as, unlike 


\section{TIMBER SUPPLIES AND RUSSIAN FORESTS}

our other Allies, we have no forest resources of our own at our back, to institute fellings on a large scale in those of her forests which are adjacent to the most suitable ports. Every saw-mill in these regions should be set to work converting timber at high pressure, the materials being stacked in suitable depôts for transport to the areas required at the earliest possible moment. A definite scheme for the freight vessels necessary should be drawn up and the tonnage required be earmarked for the purpose for which it is to be employed. As soon as the ports or any port of supply becomes open a part of this tonnage should be made available to start bringing the materials ready to the spots arranged upon. This question of freight vessels has been very much before the public latterly. In itself it has of course greatly enhanced timber prices. The maintenance of the present prices is no more to Russia's advantage than ours or any of the other Allies, since we all have to foot the bill. To undertake the above sketched scheme money will be required to finance the saw-mills, open up inaccessible areas, pay the sawyers and so forth, and my suggestion is that the British Government advance the sum which will be required for the purpose; whatever the sum necessary, it would be a mere bubble in the enormous present expenditure, and the savings which would result would several times over recover the amount spent. It would be money well laid out.

All that is required is a practical working scheme. So far as a study of the question has enabled a conclusion to be formed it appears that the one practical possibility is to be found in Russia and Russia alone. 
It appears to be inadvisable to depend on the possibility of obtaining the materials to any great extent from the forests of the Central Powers. We have got to beat them first. No one doubts that we shall, but no one knows how long the war will be prolonged. We should face the position as it now is and make arrangements which will depend for their fulfilment on the Allies alone and on their resources. A brief outline of a suggested scheme is only attempted here. A perusal of the following three articles will, it is trusted, indicate that it is based upon some considerable foundation.

We now come to the second point which requires consideration :

(2) An arrangement under which our timber requirements during the next forty to fifty years may be assured.If Great Britain takes up the afforestation question on the scale now so urgently demanded we shall have to wait thirty-five to forty-five years (save in exceptionally favourable areas when the period may be shorter for some species) before we obtain a yield of pitwood and a longer period for timber of larger dimensions. To bridge this interval therefore we should make suitable arrangements in order to ensure supplies reaching us at a price at which, economically speaking, it will pay us to take them. A survey of the regions from which such supplies are likely to be available during the next forty years is by no means reassuring. It is scarcely possible to credit that some of the countries on whom we have drawn so largely in the past or are so heavily indenting upon at the present moment, and to whom we are paying preposterously high rates for the materials received-it is scarcely possible to 
believe that these countries will be able to continue to satisfy our requirements during the next forty to fifty years. Take the countries across the Atlantic in the first instance. Is it likely that America, with her own colossal demand for timber of all classes and her rapidly diminishing area of, for our purpose, accessible forest, will be able to supply the European market for many more years? Canada again is a country with a rapidly increasing population. She has extensive forests. But a great part of the more accessible areas have been cut out. It is not easy to estimate how long she could help the Mother Country with supplies, but it is difficult to perceive how, with her own growing requirements, she could do so for anything like this period. And in each case the cost of transit of the raw material, as the more accessible forests are cut out, will increase and must inevitably react on the prices and keep them high. The controversy which arose a few years ago over the question of Canada granting America a preferential tariff for wood pulp must be fresh in the minds of many. And how long in any event are these countries likely to be willing to export raw materials as against manufactured articles? Our industries require the raw materials. It cannot pay us to import manufactured ones. A tariff on raw material would kill our industries. Newfoundland may help us for a time with wood pulp, but that is only one item of our requirements.

Turning to Europe, the countries from which we have mainly drawn our supplies in the past are Norway, Sweden, and Russia. It is difficult to credit that any one who has any acquaintance with the position of the 
woods of the first two of these countries would be prepared to say that either will be in the position to send us during the next forty years the same amounts of timber we have received annually during the past decade. And if the past is any criterion to the future, we shall require more! Both of these countries have been carrying out heavy fellings to supply the European timber market-not merely the British one-and it would be folly to rely upon or expect that the intensity of these fellings can be maintained for anything like the period to which we are here limiting ourselves. And this period, remember, leaves out the question of large timber for sleepers, etc., altogether; for it will take us seventy to eighty years to grow that.

A careful examination of this problem will, it is suggested, show that, omitting the Central Powers-and even if they are included the position would scarcely be very much better for Great Britain-but leaving these Powers out of the question, it can be shown that it is to Russia and Russia alone to whom we must look for the bulk of the supplies which we shall need, and must consequently obtain from somewhere, during the next forty years.

Russia has large forests, how large and how rich in materials it is the aim of the following three articles to indicate. These enormous forest areas contain large quantities of the very materials, pines, spruces, and firs, which will be so much needed in the years to come. Vast areas of forest in this gigantic country lie untapped owing either to the paucity of the population or to their inaccessibility owing to the absence of roads and other export facilities. They contain large 
amounts of mature timber-timber which requires felling and marketing before it decays and becomes worthless. In drawing attention to these valuable forests there is no intention on my part to suggest anything in the nature of the ruthless exploitation which, for instance, has taken place under the ægis of great lumber companies in the countries of the New World. Such exploitation in the past has resulted in the total disappearance of the forest in the areas subjected to this treatment. The removal of the surplus growing stock in primeval forests as yet untouched and unexploited by man is a very different affair. Under such treatment not only is the surplus harvested before it decays, thus yielding a perfectly legitimate revenue, but the forests are improved by its removal and proper plans for their future management can be drawn up.

The accounts of the forest areas in Russia in Europe, in Finland, and in Siberia which follow will, I think, show without question that they do contain a surplus stock of old material which it will be to the interests alike of the forests themselves and the Russian Government to market. And a unique opportunity has undoubtedly arrived for marketing them.

Great Britain more than any other of her Allies is totally dependent on supplies from without and must inevitably remain so for another forty to fifty years, even if she starts planting on an adequate scale at once; for the small stock of commercial woods she had at the commencement of the war will be practically exhausted at its close.

It is with Russia then that our Government should cometo an agreement-an agreement which should have 
as its outcome the certainty that a proportion of the annual amounts of timber, etc., which we require should reach us from Russia during a definite period of years.

It might be suggested that the most feasible arrangement, for there are several ways of dealing with this matter, would be to lease a considerable tract, ${ }^{1}$ or several tracts, of forest for a period of years and exploit them ourselves under such conditions as regards restocking felled areas, etc., as might be agreed upon. . We have leased oil areas in Persia. There does not appear to be any reason why we should not assure our timber supplies for the next few decades in the same fashion. Du reste, there is a precedent of a kind ; for the Government of India leased the valuable deodar forests in the Western Himalaya from their local chieftain owners and exploited them. And this exploitation was commercially most successful both from the Government of India's point of view and that of the chieftains themselves.

It should, it is submitted, prove quite feasible to arrange for the lease of areas in European Russia, in Finland, and in Western Siberia of sufficient size to guarantee our requirements or the greater portion of them so far as they can be at present estimated for this period of forty to fifty years. For such a length of time must elapse between the afforestation of, we will say, 5,000,000 acres of the afforestable derelict lands in this country, provided this work is taken in hand at an early date and on an adequately large annual scale, and the period at which the woods so planted will become exploitable.

1 This suggestion was first publicly put forward in a paper I read before the Royal Society of Arts in March 1916. 


\section{VIII}

THE FORESTS OF RUSSIA IN EUROPE ${ }^{1}$

OwING to the disafforestation which the last few centuries has witnessed in Europe it was held comparatively recently that amongst European States Russia, Sweden, Norway, and Austria alone possessed areas of forests in excess of their requirements which enabled them to be exporters instead of importers of timber and other forest produce. Our Board of Trade Returns show that so far as Russia, Sweden, and Norway are concerned, the same held good up to the outbreak of the war in August I9I4. That Austria was also in the same position there is little doubt, although, owing to her geographical situation, her imports to us were small, consisting principally of oak timber. Russia has been termed the "Land of Forests" and she well bears out the name, for her woods in Europe are of enormous extent, embrace a variety of soil, climate, and species of tree, and where they exist are very intimately bound up with the welfare of the population. Of their importance and influence on the national life the following is rather

1 The information contained in this article is based on observations made and statistics collected during a visit to Russia, and on publications of the Russian Government. It formed part of an article published in the Nineteenth Century for March 1916. 
a striking illustration: Only some 4 per cent. of Russian houses are built of stone ; 30 per cent. have plank roofs, 70 per cent. thatch or wooden tile roofs, and only $\frac{1}{2}$ per cent. have iron or metal roofing !

The forests in European Russia and the Caucasus have been demarcated approximately and their contents ascertained. Those in her Asiatic territories, which are still vaster, are but little known. In their eastern parts and in portions of Western Siberia, investigations have been made to determine the extent and contents of the forests. But much remains to be explored. In the Caucasus $I 6$ per cent. of the total area is under woods, these latter covering approximately $19,354,000$ acres. The greater part of these forests extend along the Black Sea region, half of the area of the two Governments of the Black Sea and Kontaïs being afforested. In European Russia 510,300,000 acres are afforested, representing 39 per cent. of the whole country or, omitting Finland (which has 63 per cent. of its area under woods), there is still 37 per cent. of European Russia under forest. If the large lakes, marshes, etc., are excluded 33 per cent. of Russia in Europe may be taken as afforested-a high percentage. As regards the distribution of Russia's European forests, the north is well wooded, whilst the steppes of the centre are nearly free of woody vegetation. The south is less well wooded than the north, its average being about 20 per cent. In the north two-thirds of the forests are principally found in the following seven governorships-Archangel, Vologda, Olonetz, Novgorod, Kostroma, Viatka, and Perm. The Governments of Archangel and Vologda alone cover 
an area of $I, 04 I, 096$ square versts (a square verst $=28 \mathrm{I}$ acres), equal to the area of Germany and Austria together. In the south the forests are to be found in the ten Governments comprising the Vistula basin, Volhynia, Kiev, Tchernigov, Orel, Riazan, Tambov, Penza, and Orenburg. For forestry purposes Russia as a whole has been divided into the following thirteen zones, each zone having the same lines of export for its materials :

I. North.-The Governments of Archangel and Vologda, served by the ports on the White Sea.

2. North Baltic.-Comprising the Governments of Olonetz, Novgorod, Petrograd, served principally by the ports of Petrograd and Cronstadt.

3. South Baltic.-Governments of Esthonia, Livonia,

Courland, Pskov, Smolensk, and Vitebsk, served

by the important port of Riga.

4. Basin of Niemen.-Governments of Kovno, Vilna, and Grodno. The Niemen river is used to float timber exports into Germany and down to Konigsberg.

5. Basin of Vistula.-Six Governments served by the Vistula, and via Germany to the port of Dantzig.

6. Dnieper Basin.-Governments of Mohilev, Minsk, Volhynia, Kiev, Tchernigov, Podolia, Bessarabia, Poltava, Ekaterinodar, Kherson, and Taurida. Produce exported to Central Russia by way of Kiev, Kherson, and Odessa.

7. Mineral Region of the Ural.-Governments of Perm, Oufa, and Orenburg. Most of the pro- 
duce of the forests of these governments is used locally in the mineral workshops, etc.

8. Upper Volga Basin.-Governments of Tver, Jaroslav, Kostroma, and Viatka.

9. Middle Volga.-Governments of Vladimir, NijniNovgorod, and Kazan.

Io. Lower Volga.--Governments of Simbirsk, Samara, Saratov, Don, and Astrakan.

II. Central Russia.-The Governments of Moscow, Kaluga, Riazan, Penza, Tambov, Orel, Toula, Kojelsk, Veronega, and Kharkov. The produce from the forests of these regions is disposed of in the markets of Moscow.

\section{I2. The Caucasus.}

13. Siberia and Turkestan.

The bulk of the forests in European Russia belong to the State. There are, however, both private and communal forests in existence, some being State-aided, as will be subsequently shown.

It is well understood that industrial operations are developed as a direct outcome of the presence of fuel and combustible resources in a country. Russia is well off in these factors. In the north, Ural, and the north-east the factories are supplied with wood fuel, in Donetz and the Vistula basin by oil fuel, in Moscow by naphtha. Each of these forms of industry is more or less intimately connected with economic forestry. Sport and the collection of the seed of the cembran pine, important as the latter is in the winter to the population in Siberia, take only a secondary place to the real forestry industry, which, with the develop- 


\section{THE FORESTS OF RUSSIA IN EUROPE}

ment of the nation and the growth of industries dependent on large areas of forests, is taking a preponderating place in the national economy. Throughout the empire the forests play a varying and important part. In the industrial regions large amounts of timber and fuel, etc., are required in work connected with shipbuilding, railways, engineering works and chemical works using wood. In the agricultural areas sylviculture enables the more sterile parts of the tracts to be planted up, as also the fixation of the moving sands (to prevent the engulfing of valuable lands) and of hills subject to erosion, ravines, etc. Protective belts are planted to afford protection against cold and drying winds and shelter to cattle; also to provide fuel which is preferable to straw or cattle dung. In the neighbourhood of large forest areas the agricultural population work in the forests in winter to supplement their incomes. The forests are also made use of for grazing herds of cattle, and are also essential to their protection throughout the long rigorous winter period. The Kirghiz of the Asian steppes, for instance, find shelter in the winter in the forests.both for themselves and their animals; the woods also provide timber to construct their houses and fuel for burning. To the fishing industry the forests furnish material for the construction of ships and boats and also prevent the silting up of the rivers by maintaining a cover to the soil of their catchment areas, thus preventing erosion and denudation in the hills. Finally the large export trade of forestry materials from Russia makes considerable demands on her forests, in the management and upkeep and exploitation of which a large popula- 
tion finds employment. The forestry labourers proper supplement their incomes during the long dark hours of the winter by toy-making from materials obtained in the woods.

The greater number of the known European commercial timber species of trees are to be found in Russia in Europe, viz. Conifers-Spruces, Pines, Larches, Silver Firs; Broad-leaved trees-Birch, Aspen, Oak, Beech, Black Alder, Lime, Ash, Maple, Plane, Elm, Willow, Black Poplar, Box, Walnut. The chief species are found either as pure woods (of one species only) or in mixed woods, the latter being the commoner. Two-thirds of the total domanial forests of the empire consist of conifers. The most extended of these are the mixed conifer woods in which spruce predominates; then come the pure spruce woods. The fir mixed woods follow in which the firs form the chief species, then the pure fir woods. A fifth of the total domanial forests are mixed woods of conifer and broad-leaved trees, the former predominating.

The common spruce (Picea excelsa) is the most widely spread species, forming the chief tree of Northern Russia and of Siberia. P. ajanensis also occurs. $P$.orientalis is the Caucasian species and $P$. schrenkiana is the Thian Shan. The spruce grows to a fine size, and is exceedingly valuable. The Scots pine (Pinus sylvestris) comes next in extended distribution; it spreads farther down towards Central Russia than the spruce. In the Ural and Siberia the pine present is the Cembra ( $P$. cembra), valuable in Siberia for its seeds. In the mountains of North Siberia the species present is Pinus pumilio. In the Crimea $P$. taurica occurs and in the 


\section{THE FORESTS OF RUSSIA IN EUROPE}

Caucasus the Scots pine and $P$. halepensis. In this latter region the pines are, however, of secondary importance, spruces, firs, beech, and oak being the most valuable species. The pines occur as pure woods covering large areas. The birch forms a natural mixture with the pine and is the most extended of all the broad-leaved species in Russia. It is also found in pure woods which are of great value in the steppes of Western Siberia where it is accompanied by the aspen, and is used for a variety of purposes. With its light seed easily wind borne and its great adaptability it spreads itself easily, occupying areas newly felled over or burnt, etc. The birch grows to a large size, as visitors to Petrograd and elsewhere in Russia must be well aware. The tree in Russia presents very little of the appearance we are accustomed to in these islands. As widespread as the birch is the aspen, which covers large areas as pure and mixed woods both in European and Asiatic Russia. The areas of this species, like the birch, are increasing owing to the extreme ease with which it reproduces itself. It replaces the spruce in the north and the oak in the south. On suitable soils it reaches a large girth and height.

The oak is far less widespread than the above species. It is not found in the north nor beyond the Urals. It is at its best in the south, where it forms fine forests. Both European species, Q. pedunculata and $Q$. sessiliflora, occur. In the Caucasus there are several other species, $Q$. pubescens, $Q$. castanexfolia, $Q$. armenica, $Q$. macranthera, and $Q$. mongolica in the Amur region. The larch takes a considerable place 
in the forests of the north. The European species (Larix europaa) grows in the extreme west on the confines of the Carpathians and in the southern portion of the basin of the Vistula; the Siberian species ( $L$. sibirica) is widely spread in the forests of Western Siberia and is also found in the north-east of Russia in the forests of Archangel, Vologda, Perm, and in parts of Viatka and Kostroma; in Eastern Siberia the L. daurica replaces the other species of larch. This conifer only occurs pure over small areas. It is chiefly found in mixture with other conifers, chiefly pines. The common silver fir (Abies pectinata) occurs in fine extensive pine forests in the Western Vistula basin, the tree here growing very fast and reaching a great size with a high quality of timber. In the north-east of European Russia it is replaced by the Siberian fir (Abies sibirica), which here stretches into the larch zone, crossing the Urals and spreading into the Siberian forests, where it is usually found in mixture with spruce covering extensive areas as yet little exploited. The well-known Nordmann's silver fir is found in the wooded mountain; of the Caucasus, where it forms pure woods in which the tree is found of large size with remarkably fine timber of high value. The beech occurs in the south-west of the Vistula as also in the Crimea and the Caucasus. In the Vistula basin it is usually found mixed with fir, but it occurs as extensive pure woods in the Crimea and especially in the Caucasus. The tree reaches great size with a fine timber greatly sought after for furniture making. The old beech of the Vistula is disappearing, but the Caucasian forests are still almost intact. The black alder is fairly widely 


\section{0}

spread in damp localities, forming areas of pure woods remarkable for their straight boles and the considerable height of the trees. The lime ha ; a wide distribution, outside the northern regions, over nearly the whole of Russia in Europe and Western Siberia. It is not often found pure, but rarely with oak, and usually occurs as scattered trees in mixture with two or more species. In the broad-leaved forests of Middle and South Russia, the following species are found in mixtures: ash, maple, plane, pedunculate elm, common elm, and willows, various osiers, aspen, and black poplars in the lowlands near rivers. Of these the black poplar grows with great rapidity and is becoming of some importance. In the Caucasus there are a large number of woody species, over three hundred having been enumerated. In the west the box occurs growing as a lower storey beneath broad-leaved species. The wood fetches more than a rouble the pood (I pood $=32$ cwt.). In the forests of Turkestan the walnut has a particular value. It produces knobs and excrescences of large size which sell at as much as 20 roubles the pood.

The present development of the Russian forests may be told in a few words. Strict protective measures were inaugurated towards the end of the seventeenth and commencement of the eighteenth centuries. In order to safeguard the timber for the purposes of naval construction, Peter the Great instituted restrictions on fellings in privately owned forests in order to enhance the value of the State-owned property of this nature. The lines on which this policy proceeded were somewhat similar to those instituted on private forest property 
by Colbert in France. The Acts of Colbert in this respect were abolished during the Revolution. But before this (about I788) Catherine II in Russia had eased the restrictions on privately-owned forest property instituted by Peter the Great. From that date the economic forestry problem as it affected the empire occupied the attention of Russian statesmen. These efforts resulted at length in the law of April 4, I888, in the reign of Alexander III, under which a proper system of forest conservation was inaugurated. Forests which were being overcut were placed under restrictions and valuable woods, as yet untouched, were opened out by the improvement of communications. The law also made express provision for the planting up of areas of moving sand threatening to engulf valuable agricultural land, for the protection of hillsides from erosion and the catchment areas of the great rivers, so important for the floating of timber and for fishing purposes, etc. A Forest Department was created with its central administration under a Director-General of Forests with two Assistant Directors placed under the Minister of Agriculture. The headquarters of the Department, presided over by the Director-General, is divided into ten sections. Purely technical forestry questions are settled by a forestry committee of professional experts to which is attached a Forestry Bureau. The work of this bureau is to examine the whole forestry problem of the empire, both from an economic and general point of view ; to decide upon the value of new suggestions for working particular forests, and to report on forest inventions and special points or questions submitted 


\section{THE FORESTS OF RUSSIA IN EUROPE}

for consideration by local administrations or private persons. Joint Forestry Advisers are maintained by the State, each with his own area of operations, to advise private proprietors as to the management of their properties and to aid them in preparing plans of management for these areas. Seed and young plants are sold to private owners at reduced rates. Expert foresters engaged by private proprietors to manage their woods have been placed on a similas scale of salary and promotion to that enjoyed by State forest officers and are rewarded in the same manner with State honours and distinctions. Forestry Institutes and Colleges are maintained for the proper training of the upper and lower forestry staffs. The Forestry Institute at Petrograd for the training of the upper controlling staff, a magnificently equipped forestry building, the largest in Europe, has been in existence for over a century. Research work is carried out at experimental stations, and several Forestry Societies are in existence.

The first systematic plans of exploitation of the forests of Russia were made for those in the mineral districts in 1840 . Since then very large areas of woods have been brought under proper forest management. The general rotations are from 80 to 100 years for high forests, and 30 to 60 for coppice. Where possible felled areas are naturally regenerated, i.e. restocked from seed falling from a few trees left standing per acre for the purpose. Latterly, however, artificial re-stocking by planting up with young plants or by sowing seed direct upon the area is being more and more resorted to. Considerable attention is being 
given to the planting of areas of waste land in populated districts poor in forest and in planting shelter belts for stock and the protection of the crops; also, as already mentioned, in the planting up of shifting sands and areas subject to erosion in the hills.

The next point of importance, a most interesting one to Great Britain, is the question of the amount of materials available for felling and more especially for exportation in the Russian forests. A few years ago it was officially recorded by the Russian forestry authorities that they were cutting far below what is called the possibility; in other words that the increment put on in the woods each year was far in excess of the amount of increment, i.e. the volume of timber, taken out. Also that large areas of old woods which had practically ceased putting on increment and were going back, i.e. losing their sale value, remained standing owing to the impossibility of selling and felling them. The Government estimate of the fellings was that they were removing something under 50 per cent. of the possibility. Matters have altered somewhat since. But there would appear to be a considerable margin to work upon. Of course the chief deterrents to heavier fellings have been scanty population, absence of industries requiring wood, and want of communications, roads, etc., the latter the chief and greatest obstacle. The following example will render this obvious. The larger portion of the State forests are found in the north in the Governments of Archangel and Vologda. Owing to imperfect communication these forests are difficult to work. Consequently whereas the annual fellings laid down were 


\section{THE FORESTS OF RUSSIA IN EUROPE}

7 cubic feet per acre, the amounts actually felled were only 7 cubic feet per acre or about ro per cent. Outside these two Governments the fellings to be made in the State forests were fixed at 22 cubic feet per acre. Only I 3 cubic feet per acre were actually felled, or about 60 per cent. of the prevision. The Vistula basin, where the highest prices were obtained, and the less wooded areas of Central Russia showed better returns, only 6 per cent. of the prescribed cuts remaining unfelled. The Governments of Poltava, Veronega, Lublin, and Radom gave returns of $8 \mathrm{I}$ cubic feet per acre of the afforested area. The prices obtained for the various forestry produce naturally vary greatly in different parts of the country. It would not serve any useful purpose to consider this here. Nor need we pause to deal with the fellings made in the private and communal forests of which the returns available are doubtful, since the exact amounts of the fellings and prices obtained are difficult to ascertain.

The trees in the State forests are usually sold standing on sealed tender, or by auction, the buyer felling and transporting the produce. State fellings and conversion of the material is only undertaken in rare instances. One of these was during the construction of the Siberian Railway and the installation of the Settlements.

Fellings take place between the middle of October and the middle of March. In the north labour is plentiful, the forestry industry being the chief source of livelihood of the population. In Central Russia and in the west there is also no labour difficulty, since the winter puts an end to agricultural activities and the 
people are available for forestry work. Work is usually paid by the piece. Wages are cheapest in the scantily populated areas in the north and east. For the initial transport of the felled material from the forest horses are generally used to convey it either to the river, railway station, or the nearest local market. The transport is done in winter, snow and frost being counted upon to give the otherwise impracticable roads a hard even surface and render them negotiable. Streams, rivers and canals are the most practical, as they are the most used of all communications for the transit of the forest produce to the distant markets, and Russia is well off in all of these. The rivers, of which we daily read so much in the newspapers, are put to a very different purpose in peace time. Then you may see great rafts of timber, floated many miles from the forests in which it was cut, proceeding silently down-stream to some distant market. The length of floatable water is thus estimated-69,000 versts (a verst $=$ about two-thirds of a mile) floatable, 83,000 versts navigable for boats, and 50,000 versts navigable for steamers. It is estimated that European Russia possesses 25,000 versts of river exclusively reserved for the floating of large rafts of logs, etc., I,500 used by the timber boats of wood merchants, 38,500 versts of double tow paths, together with 26,000 versts navigable by steamboats. There are only about 2,000 versts of canals. The most important river is the Volga, and tributaries connected by canals with the Neva and the Northern Dwina ; then comes the Dnieper, Western Dwina, Niemen, and the Vistula. The period during which the rivers, which are free to all for this purpose, 


\section{THE FORESTS OF RUSSIA IN EUROPE}

may be used for floating is the "open" season, i.e. when they are not ice-bound, and the same applies to the streams (five to eight months). In some Governments, Archangel, Vologda, etc., permission, which will usually be granted, must be first obtained from the Government.

The railways also help, to a smaller extent, in the carriage of the produce of the forests, but the freights are of course much higher than for water-borne materials.

We now come to a consideration of the wood industry itself. This industry has made the most extraordinary development in recent years. In 1877 its total value was only about $17,000,000$ roubles. In 1897 it had reached $103,000,000$ roubles. It is now nearer $200,000,000$ roubles $(£ 2 I, 667,000)$.

The chief branches of this industry are the saw-mills, of which there are some 2,000 in the country. The most important are to be found in the Governments of Archangel, Livonia, and Petrograd. The materials sawn up in these mills are mainly exported, the greater part to Great Britain. Elsewhere the chief mills are situated at the mouths of the Volga, Dnieper and the Don, and in the Governments of Orel, Saratov (especially the town of Tsaritayne), Volhynia, Petrokov, Kherson, Smolensk, Kiev, Novgorod, Olonetz, Jaroslav, and Keletz.

The companies which own and run these mills are well-known commercial undertakings and in some cases are very intimately concerned with the forestry materials exported from Russia to this country. In fact, the saw-mills may be considered to be one of the 
most important factors connected with the foreign export trade.

Next to sawn timber comes furniture making, which is an important industry. The chief factories are to be found in the Governments of Petrograd and Moscow. Cooperage also employs a considerable amount of labour in the Governments of Astrakhan, Kherson, Kontaïs, and Jaroslav. Amongst subsidiary forestry industries are those of the wheelwright and coachbuilder, which chiefly flourish in the Governments of Petrograd, Moscow, and Kiev. The match-making industry is spread throughout the forest regions.

The industries of wood pulp and cellulose manufacture are still in their infancy, though both are now developing with some rapidity.

The dry distillation of wood is another industry which has a future before it. Tar, pitch, and oil of turpentine are all produced in Russia, but in comparatively small amounts considering the enormous area of the woods. The industry is, however, developing.

It will be now of interest to glance at the exports of forestry produce from Russia. A very large amount of the materials from the vast forests is of course used in the country, the chief means of transport being the rivers, down which the materials are floated. Of these the chief are the Volga and tributaries, the Dnieper and the Vistula. A smaller proportion is carried by railway, more especially in Central Russia. The material thus transported is used in the industrial and populous centres of the country. In the northern provinces, in the Governments of Archangel and Vologda, forestry materials are scarcely required in the 
country owing to the scanty population and to the absence of industries requiring wood. This area is exclutively an exporting one.

The chief Russian forestry exports are :

(a) Logs, poles, faggots, fascines.

(b) Squared timbers, posts, manufactured wood.

(c) Planks, laths, shingles.

(d) Pitch and tar from conifers and the birch, oil of turpentine, turpentine.

(e) Walnut wood, palm tree wood, and oak bark. These may be divided into five classes of exports :

(I) Raw materials.

(2) Dressed materials.

(3) Wrought or worked up (planed) materials.

(4) Products of dry distillation of wood.

(5) Products of wood.

The chief countries to which Russia exports forestry materials are Great Britain, Germany, Holland, and France. The first two take over one-fourth of her total exports. In recent years her imports to Germany have increased rapidly, the increase being greater in proportion than the increase to Great Britain. In Great Britain Russia finds as rivals in the timber markets Norway, Sweden, Canada, and the United States of America. In Germany her rivals are Austria, Sweden, and North America. Next to Great Britain and Germany, Holland occupies the third place as a buyer of wood from Russia, Sweden being a competitor. Lastly comes France-Russia's competitors in this market being Sweden and North America with Austria, who sends her oak.

A large proportion of the wood is exported by sea 
transit from the ports of Riga, which is the chief Russian port for this produce, Petrograd, Cronstadt, and Archangel. The exports to Germany are principally floated down the Niemen to Königsberg and down the Vistula to Thorn, Schulitz, Dantzig, etc.

So far as the values of the exports are concerned, Riga holds the first place as an exporting centre, from whence we get the trade name of "Riga pine." The chief materials are planks, sleepers, squared timbers and dressed timber and pit props, of which several millions are annually exported abroad. Great Britain takes the greater part of the Riga exports. Much of this material holds a high place in the timber 'markets, owing to its great excellence. Petrograd and Cronstadt take second rank as exporting centres. The material consists chiefly of sawn timber (planks), of which spruce planks are the chief. Over 60 per cent. of these exports come to Great Britain (Hull and London), 20 per cènt. to Holland (Dordrecht and Rotterdam), ro per cent to Germany, and the rest to France and Belgium (latter 2 per cent. only).

Archangel takes the third place, planks being the chief material exported, three-fourths of which are sent to Great Britain, the remainder to Holland, France, and Belgium. Tar, pitch, and turpentine are also exported from Archangel in barrels, the greater part coming to Great Britain, the remainder going to Holland and Germany. On the White Sea after Archangel comes the port of Onega, which exports abroad considerable amounts of sawn timber. On the same sea other ports of export are Kem and Kovda, Soroka and Keret. 
On the Baltic, after Petrograd, Cronstadt, and Riga come the ports of Narva, which exports annually large amounts of logs and planks, Libava (dressed wood materials), and Windaw and Pernau (the same).

On the Black Sea Odessa is the most important port, dressed and squared timber being the chief exports, principally sent to Great Britain. Oak timber is also sent to France and Algeria. Novorosiiske is also a rising timber-exporting port on this sea.

In the Caucasus Batoum is the chief port, exporting walnut wood and palm wood.

On her western continental frontier Russia's chief exports of forestry materials go to Germany. These are cut in the wooded provinces through which flow the Niemen and Vistula, the mouths of which are both in Germany. The material is principally exported as logs or roughly squared timber floated down the rivers in rafts. On the Vistula some of the material is sawn up in saw-mills situated at the Russian frontier. It is important to note, however, that all this material is not taken by Germany. A considerable amount is floated down the German portions of these rivers to the ports of Königsberg and Dantzig, both of which are important ports for the Russian timber trade, and is sent to Great Britain and Holland, etc. At this juncture this is a point worth remembering.

In spite of its great richness in forest materials, owing to inadequate development of its forest property and the poor state of communications Russia herself imports forest products, to certain of her unwooded centres, of the kind she exports from her afforested areas. Her imports consist of logs, poles, billets, 
faggots, squared timber, planks, laths, tar, turpentine, cellulose, wood pulp, valuable exotic woods, oak bark for tanning, cork, etc.

These imports could all be obtained at home either in Russia in Europe or in her Asiatic domains, except perhaps one or two of the more valuable exotic timbers, and in the last few years she has made great strides in developing her forests. How far she will be able to maintain or increase her exports from the European part of her dominions in view of the growing needs of her immense population is a matter which remains, perhaps, in some doubt. Unquestionably, however, there are still large amounts of exploitable timber in North Russia, Finland, and Western Siberia. It is a matter in which we, more than any other nation, are supremely interested.

A glance may now be taken at the Russian imports to Great Britain for the last year of which we have record before the war burst on Europe, i.e. for the year I9I3.

The materials received may be divided into six classes of produce, consisting of conifers, i.e., pines, firs, larches; and hardwoods-oaks and other broadleaved species, as follows:

(I) Logs, sawn, split, and planed.

(2) Pit props and pitwood.

(3) Wood pulp.

(4) Oak logs.

(5) Wood manufactures, furniture, etc.

(6) Foreign hardwoods.

The amounts in loads and values in pounds sterling of these materials received during the year in question were as follows : 


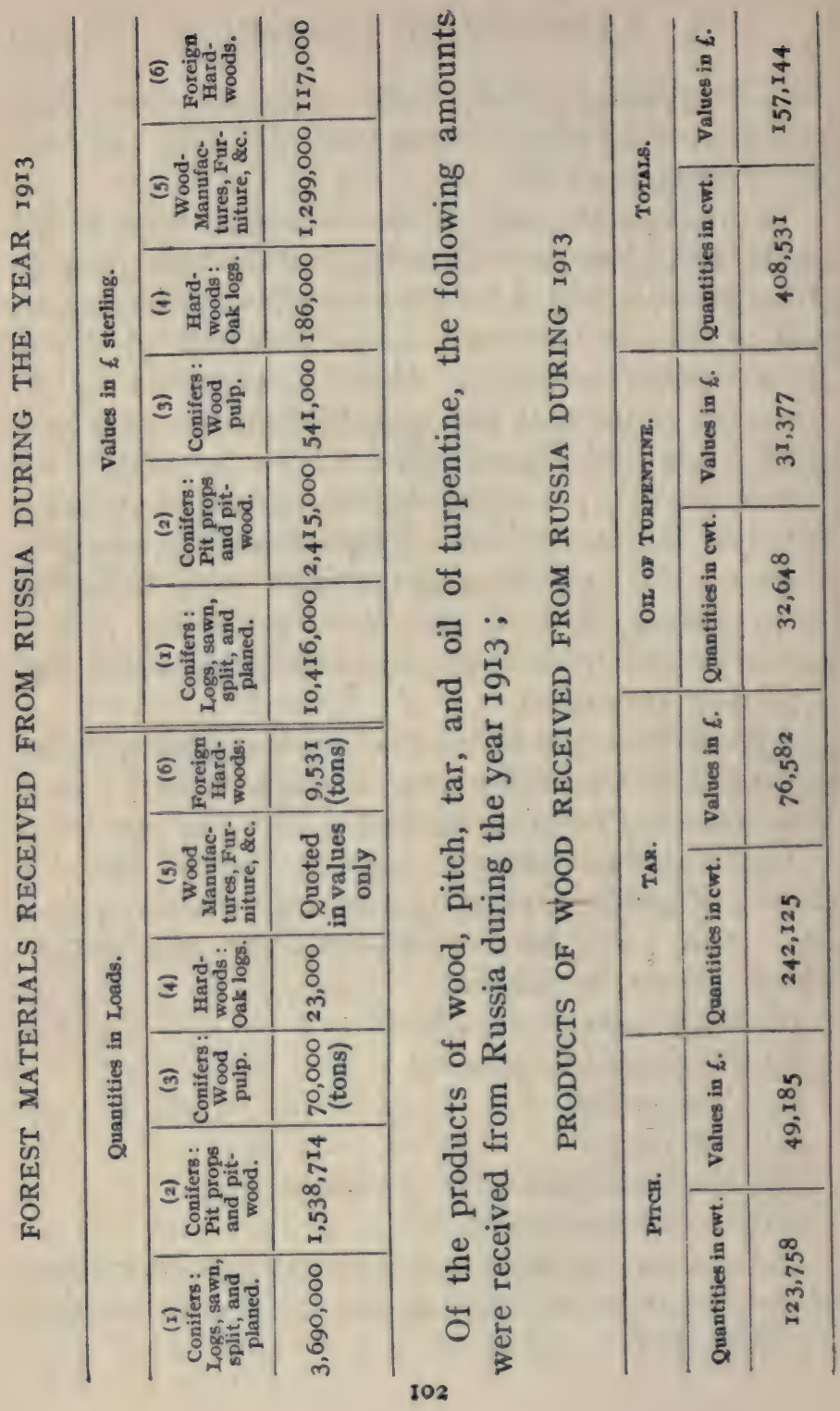


No acetone, a material of such importance at the present moment owing to its use in the manufacture of munitions, was imported from Russia during I9I3. As may be known, wood yields 2 to 6 per cent. of its weight in pure acetic acid, which is extensively used for making vinegar. In wood vinegar there is always some acetone, which is a combustible liquid in which oils, resin, and gun-cotton are very soluble. Acetone is now, of course, used in the manufacture of propulsive powders.

It would appear that Russia equally with ourselves was far from appreciating the importance of this product of wood or the danger of allowing Germany to retain a practical monopoly of it. With our extensive and valuable Indian forests and those in the Colonies we could have supplied our own needs in this material, and doubtless those of others also to some extent, at this juncture. Russia with greater ease than ourselves could have provided from her vast European forest resources all that was needed. But factories and plant are required and organisation, and all this takes time, and is difficult to arrange for in actual war time. We are getting to work now in this direction, but a more general appreciation of the need of a national afforestation programme and the economic importance to a nation of maintaining a certain percentage of its lands under woods worked on a commercial basis would have prevented our present dangerous position. 


\section{IX}

THE FORESTS OF FINLAND AND EUROPEAN TIMBER SUPPLIES ${ }^{1}$

THE Great War has given rise, in certain parts of Europe, to almost unprecedented demands for various classes of timber. The materials have been utilised in a variety of ways, outside their ordinary peace-time usages; for the flooring, walling, and roofing of trenches and dug-outs, the hutting of troops in training, the preparation of barbed wire entanglements, the handles of entrenching tools, and for many other purposes, both naval and military, which are better perhaps left undisclosed. It was estimated the other day that there were some 2,000 odd miles of trenches on the Western and Eastern fronts. To construct these an enormous amount of wood has been needed. The whole of this material is lost to the world, for what remains of it at the end of the war will never prove serviceable. This excessive consumption of wood, outside its legitimate purposes, has rendered necessary the institution of a very careful inquiry into the sources of present and future accessible supplies and

1 Atlas de Finlande. Articles by Prof. A. K. Cajander, P. W. Hannikainen (Director-General of State Forests), and A. B. Helander (Inspector of Forests). Helsingfors : Geogr. Society of Finland, IgIr. 
into the probable amounts available in the forests of the allied countries situated in Europe. Urgent as this problem has already become to some of the Allies, ourselves for instance, the question will be still more acute at the close of the war. A previously undreamtof demand must inevitably make itself felt with the advent of peace. It is becoming therefore an imperative duty-and each month that passes adds to the urgency of this duty-that the Allies should place themselves in a position to deal with the question in the least wasteful and most efficient manner possible. Owing to our insular position, we are, or should be, even more concerned in grappling with this problem than those of our Allies who will have forest resources of their own to fall back upon. Competition in the timber markets at the close of the war between countries now fighting as close allies will on the one hand be playing into the hands of the Central Powers, and on the other be alike fatal to true economy and to rapid progress in the rebuilding of the towns, villages, and homesteads which have practically ceased to exist within the areas devastated by the operations of war. And this great demand, even in the absence of such competition, must, it is to be feared, react unfavourably on industries dependent on wood for their raw material. The economic questions involved require to be carefully thought out and a settled plan of action determined upon between the Allies now.

The great forests of some of the European nations and their contents, both in volume of timber, sizes and classes of materials, and estimated values, are more or less well known. For instance, the fine forests of 
the Central Powers and their prospective value and importance when peace comes can be more or less correctly estimated. The same may be said for the forests of France and of some other western European nations. Norway and Sweden, as is well known, have continued to supply, down to the commencement of the war, and in fact to the present time, large amounts of materials of the classes here under consideration. It is difficult, however, to forecast the extent to which they will be able or prepared to assist us in meeting the infinitely greater demands which must arise in the near future. They have been taking advantage, Sweden especially, of the high prices now existing. But are they prepared to continue to do so and can their forests stand the strain? Sweden has been cutting very heavily in her northern forests for several decades past, large tracts of which were leased about the middle of last century to big saw-mill companies. There appears little reason to expect, or even, in the future interests of the countries themselves, to hope, that the Scandinavian Governments will continue to consent to the exhaustion of their forests even to take advantage of an excessive inflation of prices. It has also become the duty of the countries most directly concerned to endeavour to prevent such an inflation of prices as would be the immediate outcome of direct competition amongst themselves in the timber markets. At the same time, it is a first necessity in the interests of future generations that the forests of Europe should be so managed that as little interference as possible may take place in the existing plans of management of the woods. Such 
plans are primarily based on the removal of the normal increment; or, to put it in more popular language, on the removal of the annual interest, while the capital is left behind intact. Over-cutting means trenching upon the capital, interference with the supplies of the future, and is financially unsound in the case of large areas of forest managed by the State on commercial principles in the interests of the community.

It is admitted that to some extent it should be possible for America and Canada to assist us in this matter. They have, in fact, been taking advantage of the high market rates, but it is these rates which it is imperative should be brought to a lower level at the close of the war, and if possible before this problematical date. This problem, in its main issues, is one for the Allies alone, and they will certainly be called upon to solve it for themselves.

The sources of supply form the first point for consideration. It becomes necessary to ascertain whether there exist in Europe accessible areas, or areas which can be made accessible with comparative ease and at a remunerative outlay, of commercially exploitable forest which can be utilised to supply the heavy demands which will exist. There are other matters of urgent importance, such as the afforestation throughout Europe of all land which in the opinion of experts will prove financially sound in the interests of the several communities. This and other problems which will arise have to some extent been already dealt with.

Having settled upon the source of supply, the next point to ascertain is whether the commercially exploitable forests referred to above contain an excess of old 
growing stock, i.e. whether, owing to insufficient demand in the past, or to a scanty population, to their inaccessibility, or the existence of forests in the country with better export facilities, these forests have been left unexploited up to now. It is forests of this nature which the world has been busily cutting out for over a century, and more especially since the advent of steam communication. The greater part of them have been already exploited or ruined by fire and other causes. Tracts of considerable size and practically untouched do, however, exist; and Russia probably owns the greatest area of them in Europe. A considerable portion of these forests are managed by the State Forestry Department of the country, and, save in the more densely populated parts, the fellings made annually in these areas have been far below the possibility ; in other words, want of demand or of export facilities have rendered it impossible to remove the annual amount of timber which proper forest conservancy and a correct management of the areas on financial lines would indicate and justify. Russia proper has been already dealt with. There remain Finland and Siberia, both of which contain vast tracts of such forests, some more accessible than others. It is proposed here to confine ourselves to a consideration of the forests of Finland, which, owing to their proximity to the sea and their comparative accessibility, should, if the matter is managed on statesmanlike lines, prove of incomparable value to the Allies in the near future.

Finland forms the N.W. corner of Russia in Europe ; it is bounded on the south by the Gulf of Finland; the lower half of its western shore is washed by the 
Gulf of Bothnia, while the upper half is bounded by Sweden.

From time immemorial the forests of Finland have played a very important part in the development of the country. In the distant past, when the population lived a nomadic existence, they hunted in the forests to supply themselves with food. With the advent of agriculture, the forests still continued to play an integral part in the life of the people. Areas were felled and burnt to provide additional room for the raising of crops, the ashes of the burnt materials forming a valuable manure for the new fields. The method is still practised in Eastern Finland, economically wasteful as it is. Materials for building purposes, heating and cooking, agricultural implements and so on, were all derived from the forests. But except to provide the local needs of the population the forests had little other use. Until comparatively recent times there was no export of forest produce, nor were the forests conserved in any way. Small beginnings were made in I862-3 with the establishment of a Forest Service and a forest school at Evo. But progress languished. It was thought that agriculture would pay better; and for years subsequently all efforts were concentrated upon this business. It was gradually perceived, however, that the high hopes placed on successful agricultural development were to be disappointed; exports of agricultural produce remained small, while, so late as 1907 , Finland was importing over $£ 4,000,000$ worth of cereals, grain, etc. On the other hand, during this period, the value of the forests gradually increased. The exports of timber, from 
being negligible, amounted in 1907 to nearly $£ 9,500,000$ sterling, or 70 per cent. of the total exports of the country. And this in addition to providing all the wants of the local population.

The greater part of Finland, with the exception of the coastal regions, where the soil is argillaceous and more or less fertile, and the great prairies stretching along the rivers of Ostrobothnia, is a forest country. The soil is poor and stony and the climate cold-both factors more adapted to tree growth than to agriculture. Other points favourable to the maintenance of the forests of the country are the ease with which they can be renewed naturally by seed falling from parent trees, thus eliminating the expenses of planting ; the small snowfall, which does not impede felling and extraction operations in the winter ; the abundance of water transport, which forms a net-work of excellent communications; and the amount of available waterpower for driving saw-mills, etc.

The State owns about 36 per cent. of the area of Finland, or $32,804,695$ acres, excluding some small areas purchased by the State for various purposes. Of the above area $32,078,457$ acres are covered by Government forests, the remaining 726,238 acres comprising chiefly farms and other Government enterprises. This large area was constituted a State forest in olden times, as in so many other countries, when forests were not considered to possess any economic value, all land not at the time under private ownership, or occupied by villages, becoming crown property. At this period the area was considerably larger than 36 per cent, of the whole country, large grants having 
been made from time to time for extending cultivation and other purposes.

Even at the present day such grants continue to be made, but only after a careful examination of the areas to ascertain whether they can be put to better economic use than by the growth of trees; for the economic value of the forest, in the interests of the people and the country at large, is now fully recognised. Accordingly, the Government has within the last few years extended the forest area in the south and centre of the country by purchasing extensive areas of privately owned forests. The following table shows the approximate areas of forest in the eight Governments of Finland :

\begin{tabular}{|c|c|c|c|c|c|c|}
\hline \multirow{3}{*}{$\begin{array}{c}\text { Name } \\
\text { of } \\
\text { Government. }\end{array}$} & \multirow{3}{*}{$\begin{array}{l}\text { Area, } \\
\text { including } \\
\text { water, } \\
\text { in acres. }\end{array}$} & \multicolumn{5}{|c|}{ Estimated approximate areas, in acres. } \\
\hline & & \multicolumn{2}{|c|}{ Cultivated lands. } & \multirow[b]{2}{*}{$\begin{array}{l}\text { Best quality } \\
\text { forest soils. }\end{array}$} & \multirow{2}{*}{$\begin{array}{c}\text { Better classes } \\
\text { of marsh and } \\
\text { fenland. }\end{array}$} & \multirow[b]{2}{*}{ Water. } \\
\hline & & $\begin{array}{l}\text { Tilled } \\
\text { land. }\end{array}$ & $\begin{array}{c}\text { Meadows } \\
\text { and burnt } \\
\text { areas. }\end{array}$ & & & \\
\hline Nyland & 6,662 & 85 & 190 & 4,755 & I, I 32 & 500 \\
\hline Abo. & 368,467 & 3,187 & 8,030 & 174,237 & I 73,117 & 9,875 \\
\hline Tavastehus & 249,757 & 3,530 & 5,837 & I 46,8 I 5 & 84,420 & $9, \mathrm{I} 45$ \\
\hline Viborg : & 624,132 & 365 & 4,832 & 322,317 & 260,835 & 35,682 \\
\hline St. Michael & 102,627 & 537 & 680 & 64,412 & $3 \mathrm{r}, 462$ & 5,535 \\
\hline Kuopio . & $\mathbf{r}, 318,197$ & 1,425 & $7,55^{2}$ & 668,242 & 597,847 & 43,130 \\
\hline Vasa & $\mathrm{I}, 034,430$ & 4,715 & 13,332 & 527,700 & 465, I 55 & 23,527 \\
\hline Uleaborg . & $28,374,562$ & 6,242 & I 10,977 & I I, 8 I 4,245 & I $5,294, x_{47}$ & $\mathrm{I}, \mathrm{I} 4^{8}, 95^{\circ}$ \\
\hline Total & $32,078,834$ & 20,086 & I $5 \mathrm{I}, 430$ & $13,722,723$ & I6,908, I I 5 & $\mathbf{I}, 276,344$ \\
\hline
\end{tabular}

The above figures show that forest soils of the best quality occupy an area of only $13,722,723$ acres, or 43 per cent. of the total forest area. Bog or fen areas of the better class $\left(16,908, I_{5}\right.$ acres) are either covered with forests or are rocky and bare areas of little forestal 
importance. A portion of the good quality forest soils are situated in the far north, and the forests on them are chiefly maintained for protective purposes. There remains, however, a large area of State forests containing merchantable timber of good quality. But this does not by any means exhaust the forest resources of the country. In I 899 (the last valuation made) it was computed that there existed $24,688,677$ acres of private forests occupying best quality forest soil, and 4,597,235 acres of afforested bog and fen land. These figures include areas of forests on Government farms, ecclesiastical farms, and communal forests. The communal forests, belonging to towns and villages, are of interest. For instance, the town of Kajana, which owns the largest forest estate, possesses an area of 24,I92 acres; the town of Torneâ about half this amount, Kuopio nearly a third, and so on.

Timber-working companies also possess forests of their own amounting to $1,421,847$ acres, managed for purely commercial purposes. No less than 55 per cent. of the country which has been cadastrially surveyed is in the hands of private proprietors, who thus own the greater part of the private forests. These areas, in consequence, play an important and, so far, a not unsuccessful part in the economic forest policy of the country, although their sylvicultural treatment leaves much to be desired. So far as their exploitation goes, i.e. their conversion into cash, the private properties have been the chief source of timber export in the past. In I 906 only about 13 per cent. of the raw material used by the saw-mills came from the State forests, and in 1907 only 16 per cent. In 1907 Finland ex- 
ported one million cubic metres of pit-timber and 420,000 cubic metres of wood for paper-making, while in that year all the State forests only yielded 78,000 cubic metres of these materials. There is practically no restriction to fellings made in areas of forest owned by timber companies and private persons ; and consequently their methods of working are usually wasteful and extravagant. There exists a law under which the owner is bound to take measures to reafforest all areas of above twelve acres in extent which he clears, but it is a dead letter. The future of the country, so far as its forestry resources go, will depend more and more upon the State forests, unless the forest laws are revised and drastic measures taken to enforce them. Here, however, we are more concerned with the timber export possibilities of the country at the present time ; and in this connection the whole area of forests, State and private, requires careful consideration.

The history of the forests of Finland and their nature may be told in a few words. When man first made his appearance in Finland the whole country was a vast forest. The chief trees were the Scots pine and the spruce. The pine had originally formed vast pure forests, but on the better classes of soil it was giving place to the spruce, which had come in from the East. The areas on the shores of the Arctic Ocean and the elevated mountains were bare. Between the barren area (tundra) along the Arctic Ocean and the forest zone proper stretched a narrow band of stunted birch. In the south, especially to the south-east and southwest, groves of oak occupied the more fertile soils in the plains and on the lower slopes of the hills. On 
similar soils in other parts of the country mixed woods probably existed, containing in the centre and south, amongst other species, the maple, ash, elms, lime, etc. The water-courses were bounded by meadows and fringed with narrow belts of birch and alder.

This period was followed by the drying-up of the lakes and the flooding of the forest soil by water which gave rise to vast marshes. The peat areas grew stunted pines, the swampy ones spruce or birch, or, in places in the south, the glutinous alder. Man has since then considerably modified the nature of the forests, the marked transition following the period at which he settled down on the soil in organised communities. Fire played an important part in the change. There are probably few of the afforested areas in Finland which at one time or other have not been ravaged by fire. For example, fires destroyed either wholly or partially $160,752,135,557$, and 168,905 acres of State forest in 1868,1883 , and 1894 respectively. These fires have considerably altered the distribution of the pine and spruce. The former, having a thick bark and deep-going roots, is easier able to resist fire than the thin-barked, shallow-rooted spruce. Also the young pines suffered less from frost and drought, and were thus able to occupy, with greater ease, the burnt, exposed and dried-up areas. The more often fire passed over an area the quicker was the disappearance of the spruce from the locality, the species only remaining in deep damp hollows into which the fire could not penetrate. In areas which suffered in this way in the past, the drier sandy soils are now occupied by forests of pure pine, the more fertile soils being covered with birch. 
This latter species, owing to its very light seed, easily wind-borne, and to the fact that it seeds abundantly every year, while the pine in Central Finland only produces a seed-crop every seventh year, quickly invades burnt-out areas. The year following a fire will see the birch beginning to appear. The great stretches of birch forest existing in Lapland and Northern Finland arose in this fashion. Other great tracts of poor soil existing in Finland, now absolutely devoid of tree-growth, are also chiefly the result of incendiarism, and, to a less extent, of the wasteful devastation by man of the previously existing forests. With the protection of the forests and the rarer occurrence of fires the distribution of the species again began to change. Starting from the swampy lands and damp hollows where it had held its own, the spruce invaded the pine and birch forests, forming at first an underwood. With the development in height and crown extension of this spruce underwood, it in time came to form a high forest, from which the old pine or birch gradually disappeared. Owing to the thick shade which the spruce throws on the forest floor below, no young pines or birches-both species requiring light to enable them to develop-could grow. Young spruce, on the other hand, are able to develop in the shade of their parent trees; and, owing to this peculiarity, the species gradually took possession not only of all the soils on which it was able to grow to perfection, but also of others less well suited to it, which, from a commercial point of view, were better occupied by the pine. In the coastal regions of Nyland and the Governments of Abo and Vasa the spruce is already 
more widespread than the pine. In other parts of the country, such as Ilomantsi and Korpiselka, great stretches of spruce forest exist; and here, doubtless owing to the presence of extensive swamps and deep ravines, fire was never able to spread to any great extent, so that the spruce forests were never destroyed by this agency. Another agency, probably even more destructive than fire, was the pernicious custom of "shifting cultivation." A patch of forest was felled; the felled trees were fired, and the burnt ashes strewn over the area ; and one or more successive agricultural crops were then raised upon it. As soon as the area no longer yielded a satisfactory crop without undertaking a more intensive cultivation of the soil, the cultivator moved on to another patch of forest, which he treated in the same fashion. The spruce forests were the first to be dealt with in this fashion, because they occupied the best soil. When the cultivator left the area, it was seized upon and rapidly covered by the light-seeded birch. Where the cultivation had taken place on drier areas of poorer soil, the pine subsequently appeared. Of all methods of cultivation this system is the most pernicious.

But the birch forests were not the only result of treating areas of better-class soil in this fashion. When, in course of time, the birch forests were in their turn felled and burnt for a like purpose, the birch gave place to forests of white alder; and the more often the burning took place on such areas, the purer became the resultant alder forest, owing to the fact that the alder reproduces itself by sucker and coppice shoots, and that these grow quicker than seedling birch, and 
thus in the struggle for life killed out the latter. The extensive forests of alder which exist round the villages in Carélie, in the Savolaks, and in parts of Tavastland, originated in this manner. The system, which is still practised in the east of the country with Government consent, has caused the disappearance of great areas of valuable forest in Finland. Already, in parts, efforts have been made to ameliorate the condition of affairs by burning areas of pure alder and sowing pine seed on the resultant bed of ashes. The one favourable feature of the alder forests in the past was the fact that, owing to the open nature of the woods, a fine crop of grass grew up which was used for pasturing cattle. But, as has been shown above, most of these areas would carry a much more valuable conifer forest. Large areas of privately owned " forest," if it can be given the name, consisting mostly of birch and scattered alder, are also used as cattle parks, a most wasteful method of utilising good forest land where national economy is considered.

In the north of Finland and in Lapland the custom of reindeer breeding is also destructive to the forests, by rendering it almost impossible to raise young crops of trees. Since the reindeer lichen, which grows on the moors, is not nearly sufficient for the great herds reared, the shepherds fell large numbers of spruce covered with lichens (Alectoria, etc.), upon which the reindeer, in the absence of a sufficiency of the other plant, have to feed. The State suffers considerable losses owing to illicit fellings made for this purpose in areas where the forests are very large and the protective staff too small to stop these wholesale thefts. 
The distribution of the various species of tree in the forests of Finland is a point of considerable interest at the present time.

The Scots pine ( $P$. sylvestris) is the dominant species over the greater part of the dry moorlands and areas of pure sand. It also occupies, practically alone, the numberless peaty areas. Mixed with other species, it covers the slightly better class of soils, although here the spruce is usually present as an underwood. On all these classes of soil, both favourable and unfavourable, the pine in Finland develops a fine straight stem which always finds a ready market.

The spruce (Picea excelsa and P. obovata with intermediate forms) covers the greater part of the swampy soils. It also forms the dominant species on the more fertile soils which have not been subject to bad fires. It is for this reason that the spruce is commoner than the pine in Finland proper, the sea-coasts of Western Nyland and the Government of Vasa, and the northern parts of Carelie in the direction of the Russian frontier. In the State forests in the north and in the regions adjacent to Suomenselka the spruce occupies areas in which, from the commercial forestry point of view, it is not the species most suitable to the soil. It is also present in nearly all the mixed forests which gradually pass into pure spruce areas.

The birch (Betula verrucosa and $B$. odorata) forms the chief species on the extensive tracts of Lapland and North Finland which have been subject to incendiarism. It also forms more or less extensive forests in all parts of the country which have been subject to fire, or to the pernicious system of shifting cultivation in which fire 
plays so important a part. Cattle parks are often chiefly covered with birch. It is also present in the mixed forests and in the areas which have been long worked irregularly to furnish the domestic requirements of villagers and private proprietors. The two species are found generally together, $B$. verrucosa preferring the drier and $B$. odorata the moister localities.

The white alder (Alnus incana), originally only existing as a fringe to the water-courses (with the exception of the coast in the south-west of Finland), has become, as a direct outcome of the system of shifting cultivation, the chief species over great tracts in Carélie, the Savolaks, Tavastland and the regions beyond Kajana. The glutinous alder (A. glutinosa) forms narrow pure woods along the shores of the lakes, especially in the south-west of Finland. In the south it spreads over the marshy lands, where it occasionally forms pure woods, as, for instance, in the coastal regions.

The oak (Quercus pedunculata), which formerly, in the " oak period," held a place of considerable importance amongst the forest species in the south, is now only found in small isolated woods in the extreme south. The aspen (Populus tremula) is widespread, and is found on the fertile soils as well as on the driest of the sterile moors, but only reaches considerable dimensions on the former soils, where it occasionally forms small pure woods. Larch (Larix sibirica and $L$. europaea) has been introduced and some of the plantations formed have done well. The oldest, of L. sibirica, was planted between $I 738$ and $I 820$ and shows excellent results. Willow, maple, ash, lime, and elm occur sparingly in the south. 
The oldest fellings in the forests of Finland were made for what may be termed purely domestic requirements, such as firewood, charcoal, timber for building, household and other purposes, for small enclosures, and for obtaining tar. The fellings were undertaken without system, the best materials for the purpose in view being selected and the remainder left standing on the ground. In this fashion, in the neighbourhood of villages and townships, the forest gradually became open and honeycombed with holes and glades in which birch, alder, and aspen made their appearance. The trees were also topped and hacked about to provide litter or fodder for cattle and sheep. When an outside demand for timber sprang up and made itself felt in the country, the really destructive fellings began; and certain of the privately owned forests have been more effectively ruined by the methods of felling employed than by all the previous damage they suffered from fire, shifting cultivation, and cuttings made to supply local requirements.

The sales from private forests commenced with the introduction of the saw-mill industry in the middle of last century. At first only material for the mills was required, and the damage done was not of great consequence. But soon the demand arose for pitwood, wood pulp, etc. ; and private forests were felled wholesale. Great stretches of them were often sold standing to the timber merchants, who cut everything on the ground which could be sold, what was left on the areas being worthless. Thus considerable areas of privately owned forest were ruined. In the State forests, on the other hand, the management went to the other extreme. 
The only fellings undertaken were made on what is known as the selection system. Only sound logs were sold, the oldest trees being selected here and there in the forest for the purpose. Only small openings were made in the canopy by the removal of these trees; the forest was thus kept too dense, and young trees, with the exception of spruce, had not sufficient light to enable them to develop and take the place of the old ones removed. Under the system the spruce came in and occupied soils which should have been confined to the Scots pine only. The idea underlying this method of felling was " to spare the forest," i.e. that to underfell was good sylviculture; whereas, to carry over from year to year a preponderance of mature and over-mature growing stock is neither good sylviculture nor sound forest finance. Recently this system has been modified by the order that cleanings should be made in the cutting areas when the old trees are selected and felled. The chief point for our purpose in this management of the State areas is that, as the forests have been admittedly underfelled in the past, they must contain a considerable preponderance of old growing stock, i.e. of mature timber ready for the axe-timber which it would be in the interest of the forests themselves to remove, and which should prove a great asset to the Allies at this juncture.

The Finland Forestry Department was created in I863, but owing to the almost total absence of timber sales from the forests the progress of the new Department was very slow. The protection of the forests formed its chief work and proved most necessary. The people, as has been the case in most other coun- 
tries, looked upon the forests as their own to enter and cut timber, etc., at their will ; and the forest officials had for years to face open hostility on the part of the public in carrying out the new regulations. The staff was far too small to undertake the work entrusted to it; and the revenue realised from the sales of timber, in the absence of all knowledge as to the contents of the forests, did not even cover until 1872 the expenditure of the Department. From that year a surplus, which gradually increased in amount, was realised; but the excess of receipts over expenditure only showed a notable increase (with small drops) from the year I890 onwards, as the following table exhibits :

\begin{tabular}{|c|c|c|c|c|c|}
\hline Year. & Receipts in $€$. & $\begin{array}{c}\text { Expenditure } \\
\text { in } 6 .\end{array}$ & Deficit in $f$. & Surplus in $f$. & $\begin{array}{l}\text { Expenditure } \\
\text { in \% of } \\
\text { receipts. }\end{array}$ \\
\hline I $86 I$ & 5,064 & I 8,247 & 13,183 & & $360 \cdot 33$ \\
\hline 1870 & IO, 242 & 21,389 & I I , I 47 & & $208 \cdot 84$ \\
\hline I 880 & 49,337 & 33,898 & & I 5,439 & $67^{\circ} 7^{\circ}$ \\
\hline I 890 & 108,332 & 39,126 & = & 69,205 & $36 \cdot 12$ \\
\hline 1900 & 244,900 & 47,884 & & 197,015 & 1957 \\
\hline I9OI & I 76,973 & 45,619 & & I 31,354 & $257^{8}$ \\
\hline 1902 & 185,108 & $50,54^{8}$ & & I 34,559 & 2731 \\
\hline 1903 & 326,660 & 74,540 & & 252,120 & $22 \cdot 82$ \\
\hline 1904 & 306,606 & 72, I I 5 & & 234,491 & $23^{\circ} 5^{I}$ \\
\hline 1905 & 240,775 & 88,859 & & I 51,915 & 36.91 \\
\hline 1906 & 349,790 & 90,752 & & 259,037 & 25.94 \\
\hline 1907 & 496,717 & I I I, 253 & & $3^{8} 5,463$ & $22 \cdot 40$ \\
\hline 1908 & 463,396 & I $47,42 \mathrm{I}$ & & 3 I 5,974 & $3 I \cdot 84$ \\
\hline I909 & 464,089 & 189,529 & & $27^{8}, 559$ & $40 \cdot 80^{\circ}$ \\
\hline $1910^{1}$ & 660,000 & 195,000 & & 465,000 & $29^{\circ} 00$ \\
\hline
\end{tabular}

These figures prove two things: (I) a satisfactory progress in the exploiting of the Government forests between the years 1900 and I9Io; and (2) that the additional expenditure for additional staff, opening

1 Approximately. 
out of communications, and so forth, led to a satisfactory increase of receipts, a result well understood by the forestry expert.

The receipts and expenditure and free grants of forest produce for the State forests of Finland between the years I86I and I9Io may be diagrammatically shown as follows:

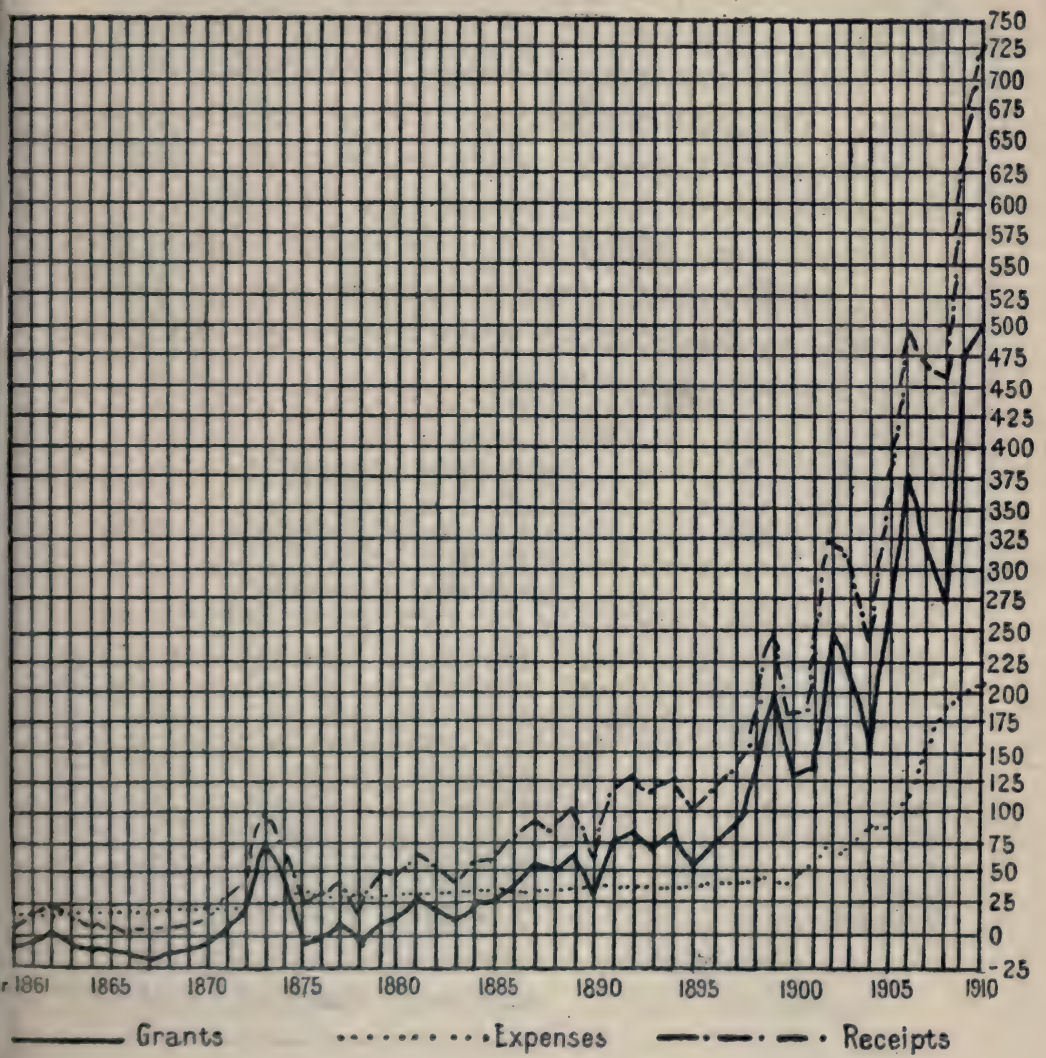


The work of enumerating the contents of the State forests was commenced in 1904, and some progress has been achieved in this direction, the object being to draw up plans of working for periods of ten years, under which a regular system of fellings and regeneration of the areas cut over will be undertaken. These enumerations of the standing crop in the various forests brought out the pleasing fact that the number of trees of timber size proved to be considerably greater than had been anticipated, especially in the northern districts. The work is still uncompleted, and the Forest Department are as yet unable to definitely state the numbers of trees of timber size ripe for felling.

The following table based upon actual enumerations of some forests has been drawn up for the ten Forest Districts in the country which are in the charge of Chief Forestry Inspectors:

\begin{tabular}{|c|c|c|c|}
\hline District. & $\begin{array}{l}\text { Stems with a } \\
\text { diameter of } \\
30 \mathrm{~cm} \text {. (1 117 } \\
\text { inches) or more } \\
\text { at a height of } \\
4^{\prime} 3^{\circ} \text { from } \\
\text { ground level. }\end{array}$ & $\begin{array}{l}\text { Stems with a } \\
\text { diameter of } \\
95-30 \mathrm{~cm} \text {. } \\
\text { (9t-rrts inches) } \\
\text { at a height of } \\
4^{\circ} 3^{\circ} \text { from } \\
\text { ground level. }\end{array}$ & Total. \\
\hline 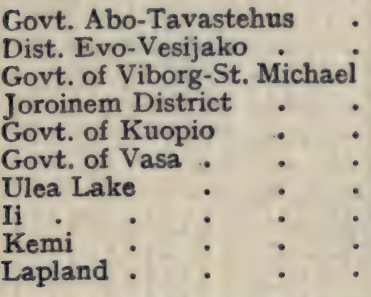 & $\begin{array}{r}2,628,824 \\
78,192 \\
2,701,818 \\
41,520 \\
5,290,605 \\
2,622,760 \\
4,787,587 \\
5,887,168 \\
13,870,000 \\
13,457,133\end{array}$ & $\begin{array}{r}3,539,383 \\
319,914 \\
4,803,933 \\
352,270 \\
7,580,420 \\
4,439,414 \\
7,349,668 \\
10,438,643 \\
13,129,964 \\
17,974,086\end{array}$ & $\begin{array}{r}6,168,207 \\
398,106 \\
7,505,751 \\
393,790 \\
12,871,025 \\
7,062,174 \\
12,137,255 \\
16,325,811 \\
26,999,964 \\
31,431,219\end{array}$ \\
\hline - $\quad$. & $51,365,607$ & $69,927,695$ & $121,293,302$ \\
\hline
\end{tabular}


Some I2I,000,000 trees, of approximately Io inches diameter and over, at 4 feet 3 inches above ground, therefore exist; and, in the present exceptional circumstances, considerable fellings could be made to remove old growing stock, ripe or over-ripe. Its removal, with the additional transport facilities which would doubtless in places require to be created, should place the Department in a far better position, and in a far shorter period of time than could have otherwise been hoped, to take up the many interesting sylvicultural questions which demand attention in these forests. The trees in the State forests are usually sold by auction standing, chiefly by the stem, but also by volume. A deposit must be previously made by bidders, which is forfeited if the bid is not completed. The bids are submitted to a higher authority and may be refused or accepted; in the latter event the bidder completes his payment before felling and extracting the trees. These auctions for the big timber are carried on in August at large centres. Smaller auctions, at which the smaller material is disposed of, are held locally as may be required. Even here the offers have to be submitted to the district forest authority before they can be accepted. The chief difference between the two auctions, omitting the size of the timber, is that for the small material one year only is allowed between purchase and its removal from the area, whereas for the larger timber two or more years may be granted to the contractor to fell and extract the trees purchased, these trees having previously been marked by the forest staff.

Latterly the Department has been working depart- 
mentally, i.e. felling and converting the trees in the forest itself and selling the converted material on the spot to purchasers. The Department appears to favour this method. But, except in abnormal circumstances, experience has shown, in other places where the method has been tried, that the trouble entailed usually so ties the hands of the staff that necessary inspection and protective work and the proper sylvicultural care of the forests are sacrificed, to the ultimate detriment of the woods themselves, although doubtless at the time a greater revenue is made. The departmental work in this instance is undertaken to supply Government Railways with sleepers and fuel for the engines, and with material for the three existing Government saw-mills.

The following table for the twelve years 1898 to 1909 shows the numbers of stems sold at the main public auctions, the sales at these furnishing the best indication of the prices obtained for large-sized timber and of the increased demand during the period:

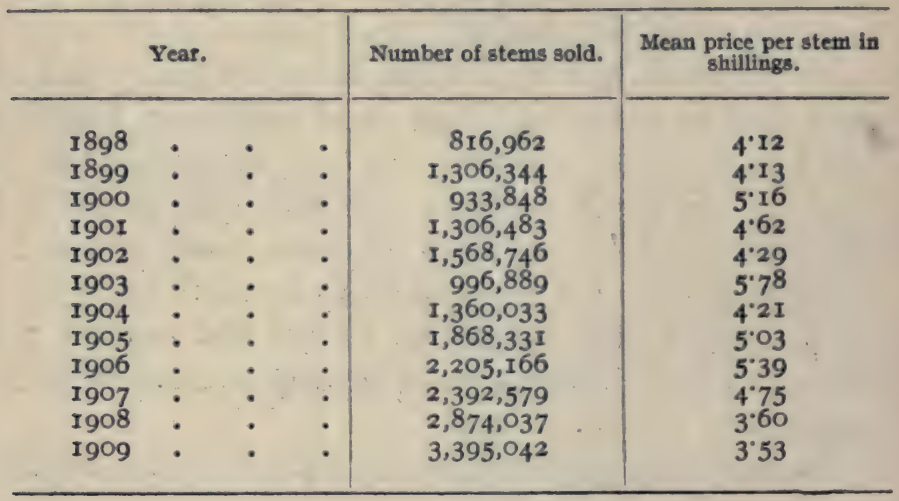


The drop in the mean price is explained by the fact that in 1908, Ig09 the chief fellings were made in the great forests in the north, where prices always rule lower than in the centre and south of the country; it was also to some extent attributable to the fact that the marking of trees for sale is now done on better sylvicultural lines, the selection not being made only amongst the finest stems, as was formerly always the case ; the system of cleanings having, as has been already stated, come into operation. In 1908 the total timber sold from the State forests amounted to 0.24 cubic metres

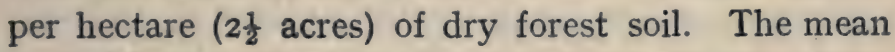
annual increment of wood put on per hectare has been valued at I' 5 cubic metre for the whole country. There should therefore be, and in fact is, a considerable excess of mature timber in the State forests.

The figures of exports from Finland in 1907 show the following forest produce exported from the country :

Poles, stems and logs .

Net measurement in cubic metres.

Pitwood and wood for paper pulp .

Fuel

Beams, approx. in the round

Spars, squared, approx. in the round

Sleepers, approx. in the round

TOTAL

215,727

I, I 35,008

640,892

I, I I 3

234,200

45,382

- $2,272,322$

In the same year industries absorbed the following amounts :

Saw mills • • • • • . - 5,169,025

Bobbin mills (in 1906) approximately : $\quad 177,559$

Paper pulp mills (mechanical and chemical), Ist

Paper pulp mills (mechanical and chemical),

704,975 fuel approx. .

Wheels, blocks, rollers, etc.

Charcoal making .

Distillation of tar.

TotAL . . . . $\overline{6,528,498}$

350,000

I3,500

33,718

79,721 
Added to this were the amounts of wood utilised on lines of communication steam-boats, which consumed 250,000 cubic metres rough measurement. Railways absorbed in I908 a total of 9,000,000 cubic metres as fuel and for other railway work; and telephones and telegraphs another I0,000 cubic metres. In round figures it way be said that in 1907 industries and exports utilised about $10,000,000$ cubic metres of wood net measurement. Now of this total only $1,303,582$ cubic metres was of State forest origin. The remainder, a total of $8,500,000$ cubic metres net measurement, came from the privately owned forests of the country. This is an important point, for these private forests are by no means yet exhausted; and therefore to the estimated total of $121,000,000$ trees with a diameter of approximately Io inches and over at 4 feet 3 inches above ground existing in the State forests must be added a total probably as large, and in all probability far larger, standing in the privately-owned forests.

It has been estimated that the domestic requirements of the population absorb $13,186,452$ cubic metres net measurement, in addition to the amounts given above. These materials are, however, of small size and do not affect the question from the point of view here considered. It is the commercial timber which exerts the chief influence on the exploitation of the forests; for it is the timber markets which demand the finest timber, the local requirements being satisfied with inferior qualities. It is the big markets which attract the private owners of woods, as also, to a considerable extent, the Government owner ; since it is in these markets that the best prices are obtainable for the 
larger material which they are in a position to supply.

An endeavour has been made to point out in this article ${ }^{1}$ that in the forests of Finland there exists one direction at least to which the devastated countries may look to obtain materials at a reasonable price with which to repair the destruction wrought by the Great War. Those industries in the Allied countries which depend upon timber for their raw material may also hope to obtain a part of their requirements from these forests. But both these possibilities remain possibilities only. It will depend on the Government being sufficiently far-seeing to come to some definite working arrangement between themselves and Russia before the war closes, if advantage is to be taken of existing opportunities. And the Finland forests, with their easy export facilities offered by their numerous waterways and available timber of the kinds which will be most in demand, Scots pine and spruce, present one of these opportunities. Are we in Great Britain going to see that it is taken in time?

1 This article was published in the Quavterly Review for April I9I6. 


\section{$\mathrm{x}$}

THE FORESTS OF SIBERIA, INCLUDING TURKESTAN

In two previous articles, the forest resources of European Russia and of Finland have been dealt with, and some indication has been given of their undeniable importance to the Allies in a near future.

A review of the forest resources of Russia would not, however, be complete without a survey of the enormous forest tracts existing in Asiatic Russia: for portions of the great Siberian forests hold a place which cannot be neglected in the Western European timber markets, e.g. in that of Great Britain-a position which is likely to increase in value in the years to come.

As yet, however, in spite of the valuable work that has been already accomplished in the exploration and survey of these regions, it is too soon to say definitely how great will be the influence of these Asiatic Russian forests on the world's markets. The areas are so enormous that the forestry resources, that is the number, species, and value of the trees covering a very considerable tract, still remain unsurveyed.

In the year of the outbreak of the Great War, the Chief Department of Agriculture published a volume 
entitled Asiatic Russia, with an accompanying handsome volume of maps. One of the sections of this important work deals with the "forest wealth" of this enormous stretch of country. It is written by V. V. Faas, and its appearance at the present time must be looked upon as most opportune. From this and other sources open to me, it has been possible to form a very fairly accurate idea of the position, probable yield capacity and importance, both present and prospective, to the world's timber markets of these forests of Asiatic Russia.

The area of country now being dealt with stretches from the Ural Mountains to the Pacific, including Siberia, the Steppe region, and Turkestan. Lake Baikal divides Siberia into two almost equal parts, western and eastern. The western half comprises the Governments of Tobolsk, Tomsk, Enessey, Irkutsk, and the districts of Turgai and Uralsk; the eastern half has the Transbaikal, Sea-coast, Amur, and Sachalin districts. That vast tract, the Steppe region, comprises the Semipalatinsk and Akmolinsk districts, and in addition there are the great stretches of Turkestan. As will be understood, the climate, or various climates, of this extensive country vary greatly from arctic to hot, and this variation in climate is accompanied by a considerable divergence in character of the forests occupying different parts of the region.

The forests of Asiatic Russia are very unevenly distributed throughout the different Governments of Siberia, the Steppe region, and Turkestan, and, owing to the sparse population inhabiting these tracts in the past, very little attention has been paid to 


\section{FORESTS OF SIBERIA AND TURKESTAN}

the woods or to their possible economic value. The scanty population was allowed to treat them pretty well as it liked. They took what they wanted from the forests, practised shifting cultivation after the fashion already described in the Finland article, or set fire to large areas annually to get up new grass on which to pasture their cattle. The building of the Siberian Railway and the influx of population from European Russia has had, it is true, some effect on portions of the forests, but the areas are so vast that it appears probable that they will be capable of furnishing materials for export for a considerable period of years.

Roughly speaking the forests owned by the State predominate throughout Asiatic Russia, the area amounting to the gigantic total of $642,600,000$ acres, or about two-thirds of the total State forests of the Empire. The forests occupying such extensive tracts naturally vary considerably in quality, but $249,750,000$ acres or 39 per cent. of the whole area is classed as rich forest soil, This percentage is small when compared with the 80 per cent. in European Russia and the 63 per cent. in the Caucasus. It must, however, be borne in mind that in the area under consideration, especially in the zone bordering on the tundra (Siberian swamp), vast tracts exist covered with a poor scrub forest with no exploitable trees in it; the areas of value being confined to the southern hill slopes, or to the valleys sheltered from the cold north winds. Large tracts of fen-land, marshy lake areas, and great stretches of burnt-over forest lands also exist in Siberia, and go to swell the total of " poor forest soil." 
The following table shows the distribution of the State forests in the Governments or Districts of Asiatic Russia, and also the numbers of forest divisions and forest estates in each division. The Russian word here translated into "division" is lesnitchestvo. It may be that our technical forest term of "circle" would more nearly express the meaning, but division will perhaps be more readily understood.

The Russian word datcha means an "estate," and it is left at that. Technically, we should probably call it a district, or if "circle" were used for the larger area, a division.

The table is as follows :

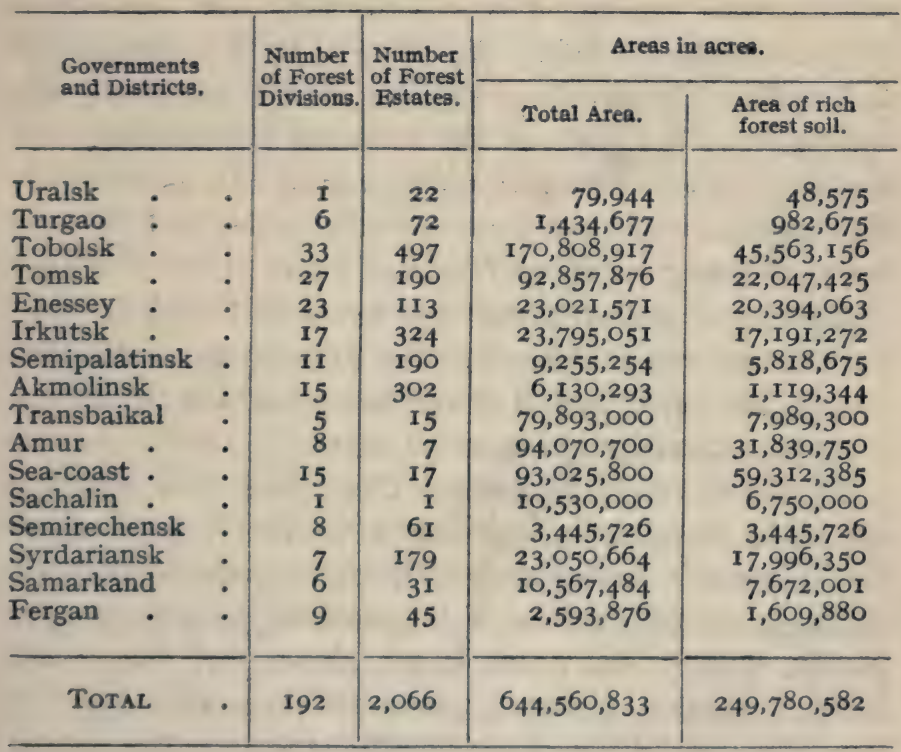

Thus there are 2,066 forest estates having an average 


\section{FORESTTS OF SIBERIA AÑD TURKESTAN}

area of $3 I I, 850$ acres apiece; whilst the average acreage of the forest division exceeds 3,356 , I00 acres. That is, the average forest division in Siberia is greater than the total acreage of the woods in Great Britain, which amounts to $3,030,000$ acres; or had that area at the commencement of the Great War. Of course all these forest divisions have not this excessive area. The average is high, owing to the enormous extent of a few in Northern Siberia, such as, e.g., one in the Government of Tobolsk which covers a tract of $8 \mathrm{I}, 000,000$ acres.

Of the total area of $642,600,000$ acres of State forest, $297,900,000$ acres or 40 per cent. have been constituted regular State Reserves, the remaining $345,600,000$ acres being still subject to the elimination of areas as allotments to settlers, or for increasing the agricultural holdings of the existing population. To the $642,600,000$ acres of forest under the administration of the State have been recently added II $8,800,000$ acres of newly explored forest in parts of the Yakutsk district, and about $10,800,000$ acres of forest of comparatively small value in the Transcaspian district, giving the total area of State forests in Asiatic Russia as approximately $772,200,000$ acres.

These do not, however, form the sole existing forests in the country. Next to the State, the greatest forest owner in the country is the Crown, which possesses some $54,000,000$ acres of forest land (chiefly on the Altai), whilst the Cossack population of the Amur district possess about $27,000,000$ acres of forest on the left bank of the Amur. Thus those of the forests of Asiatic Russia which are more or less well known 
cover the enormous area of some $853,200,000$ acres; that is, a total area greater than that occupied by either the forests of Canada (which cover 799,200,000 acres), or those of America (604,800,000 acres).

The areas of State forest containing exploitable material for export purposes vary considerably in size in different parts of Asiatic Russia. It has been shown that the country is divided into four main regions, namely the Western region of Siberia, the Eastern Siberian region, the Steppe region, and Turkestan. The amounts of "rich forest soil" in each of these regions are as follows:

\begin{tabular}{|c|c|c|c|c|c|c|c|}
\hline \multicolumn{6}{|c|}{ Region. } & Acres. & $\begin{array}{c}\text { Per } \\
\text { cent. }\end{array}$ \\
\hline I. The Wester & egio & is & ria & & - & $106,227,169$ & $42^{\circ} 5$ \\
\hline II. The Easter & gion & $\mathrm{S}$ & & - & . & I06,091, 435 & 42.4 \\
\hline III. The Steppe & ion & . & . & . & . & 6,938 ,019 & $2 \cdot 8$ \\
\hline IV. Turkestan & - & - & . & - & . & $30,723,95^{8}$ & $12 \cdot 3$ \\
\hline TOTAL & - & 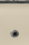 & ? & * & . & $249,980,5^{8 I}$ & $100^{\circ} 0$ \\
\hline
\end{tabular}

The above table shows that the largest areas of forests are in the Western and Eastern regions of Siberia, the acreage in the two being nearly equal; that the afforested areas in the Steppe region are very small, whilst those of Turkestan are equal to about two-sevenths of the Eastern Siberian region.

Before dealing with other important aspects of these forests, it will be necessary to give some general account of the peculiarities of the forest flora of the different regions. The tract from the Ural Mountains to the Ochotsky and Yellow Seas will be first dealt with. As may be inferred from the vast area under 


\section{I36 FORESTS OF SIBERIA AND TURKESTAN}

consideration, the climatic conditions in different parts vary considerably. There are also considerable differences in the nature of the surface formation and soil. The character of the forests is, therefore, extremely varied.

\section{The Siberian Regions}

The great region bordering on the Arctic Ocean and stretching from the Ural Mountains to the Bering Strait is designated the Arctic tundra (swamp). There are no real forests in this belt, but the area is covered more or less densely with bushes and dwarf forms. As is the case in the Government of Archangel in European Russia, patches of tall trees are found here in the far north encroaching upon the tundra. In this way small forests are to be seen even along the rivers Kolima and Anadir. In 1909 the Chukotsky expedition discovered woods in sheltered valleys at the source of the Great River (Bolshaya) and even near Cape Dezhneff. Owing to these inroads of the forest into it the southern boundary of the tundra runs in a zig-zag fashion, gradually passing into the forest zone. Next to the tundra comes the forest zone, termed taiga, ${ }^{1}$ which stretches right across Siberia to the Pacific Ocean, and occupies the tract between the tundra and the Steppe region, an area of from 1,000 to 2,300 versts broad and 7,000 versts long. This zone is very varied in character, and does not consist of uninterrupted forest. The belt is

1 Taiga-the word applies literally to the vast marshy forests of Siberia. 
constantly broken by vast fens and areas of burntover forest where only patches of the old woods exist, the rest of the tract being covered with a scrub of raspberry bushes and other shrubs. This is often the aftermath of fire, either due to incendiarism or applied in the interests of a shifting cultivation. On its northern limits the taiga first appears as separate clumps and patches of trees on the slopes of ravines and river valleys. The fir (spruce) tribe predominate in the taiga, but there are many other species of trees. This great forest zone is subdivided as follows :

Western Siberia.-From the Ural Mountains to the lower reaches of the Enessey and to Lake Baikal: This area is divided into a dry zone and a swampy zone. In the dry zone the predominating species are the so-called Siberian "cedar" or cembran pine (Pinus cembra), a valuable tree which furnishes both timber and an edible seed; the much-prized Siberian "fir" or spruce (Picea obovata), the Siberian Pichta or silver fir (Abies sibirica), and the still more valuable Siberian larch (Larix sibirica). On sandy soils pine woods are occasionally found. In the swampy zone the character of the forest changes. The larch disappears, and the spruce predominates with an admixture of deciduous species such as the birch, aspen, and alder. The most wide-spread type of forest in Western Siberia is a mixture of common and Siberian spruces. This type is interrupted here and there by the so-called urmani, a local name for mixed deciduous and non-deciduous forest in which the spruce and cembran pine predominate. In the Government of Tobolsk this urmani type of forest 


\section{I38 FORESTS OF SIBERIA AND TURKESTAN}

occupies vast tracts chiefly on the right bank of the Irtish river, and also on the $\mathrm{Ob}$ river. Generally speaking in the Government of Tobolsk the upper parts of the hills are occupied with pine, the pine being mixed on the lower slopes with spruce, larch, cembran pine, and sometimes birch, spruce and cembran pine predominating on the lowest levels. The larch is seldom found pure in this Government, as the pine takes possession of all the drier areas.

Eastern Siberia.-East of the lower reaches of the Enessey and Lake Baikal: A considerable change takes place in the character of the taiga in this region. The Siberian larch is replaced by the daur larch (Larix daurica). The daur birch also appears, with the fragrant poplar, and in the south in addition to such Western Siberian forms as alder, bird-cherry and mountain ash, the tamarisk and the rhododendron appear; further east the Mongol oak, wild apple, and the walnut commence to come in.

Eastward to the Amur and Sea Coast Districts and southward to the Manchurian forests: The further east and south we proceed the greater becomes the change in the character of the forests. The daur larch is still present, but the Siberian fir (spruce) is replaced by the Ayansk fir (Picea ajanensis), which is very wide-spread, forming thick forests in places; the ordinary birch is replaced by the Betula Ermani. The Manchurian pine (Pinus mandshurica) of great height-growth and fine quality timber appears. Pinus funebris occurs along the river Ussuri. Two silver firs are found, Abies nephrolepsis, growing in both the Amur and the Sea-coast districts; and the Abies 
holophylla, which occurs in the south Ussuri region. A yew, Taxus cuspidata, occurs in the forests of the Sea-coast district, its timber being of little value, however.

As regards deciduous species, the Amur district is very rich, the forest flora of the Sea-coast district resembling in many respects the forests of Korea, and, in part at least, of Japan. Among the chief deciduous species are two oaks, Quercus mongolica, found along the middle course of the Amur and in the south of the Sea-coast district, and Quercus grosseserrata in the Ussuri district; two species of ashFraxinus mandshurica, distributed almost throughout the Amur and the sea-coast districts except in the extreme north, and Fraxinus rhynchophylla, found in the southern Ussuri district; the walnut (Juglans mandshurica) occurring in the Amur and the central and southern parts of the Sea-coast district; the Dimorphantus mandshurica, which furnishes a beautiful veneer; and two species of lime (Tilia amurensis and Tilia mandshurica). Generally speaking, both in the Amur and the Sea-coast districts coniferous forests predominate in the north, covering the mountain slopes, leaving the lower ground to the deciduous species.

\section{The Steppe Region}

The Steppe region lies to the southward of the above-described zone. In its westward part there is a marked change in the character of the forest from that of the taiga. In the south of the Government of Tobolsk, and still more so in the Semipalatinsk and 
Akmolinsk districts, the taiga gradually yields to the steppe vegetation, and meadows and feather grass appear, occasionally penetrating far into the forest, or elsewhere completely enclosing patches of forest.

In the two districts above mentioned, the forests occupy scarcely 2 per cent. of the whole area. In the forest-steppe tracts in these last two districts, however, islands (kolki) of forest of varying size, some being considerable, occur, consisting chiefly of deciduous species. Birch and aspen are the most numerous, followed by the black alder, bird-cherry, mountain ash, black and white poplar, and acacia. Birch and aspen kolki are chiefly found in the north of the Akmolinsk district adjacent to the Government of Tobolsk, whereas the pine and the juniper occur scattered throughout this Government. In the Semipalatinsk district the Western Siberian species of pine, spruce, silver fir, and larch occur, but they are not equally distributed in all parts. Also in this part of the forest-steppe shrubs such as the sallow-thorn (Alaternus), hawthorn, raspberry, elder, white hazel, medlar, occur, and, amongst others, the dwarf almond, spiræa, and several kinds of roses. The forest-steppe region extends as far as the Transbaikal district, where it gradually merges into the black-earth steppe which possesses no forest on it, being covered with feather grass and other steppe plants, interrupted by salt marshes and sands.

\section{The Turkestan Region}

The Turkestan deserts are situated to the south, and here the shrub known as the saksaul (Halaxylon 
ammodendron) forms the chief tree species. This species grows freely over the wide tract from the Caspian Sea to Lake Balcash, in spite of the bad treatment it receives from man and the constant damage done to it by cattle. There are considerable forests on the Turkestan plateau, though here again grazing cattle do a great deal of damage, as also do fires. Many tree species are present in these forests in the Fergen, Samarkand, Sirdarya, and Semirechensk districts, the chief being the spruce (Picea schrenkiana), which forms the principal species in the Semirechensk district; the archa (a species of juniper); the walnut, maple, poplar, birch, and ash. In addition in the hill forests of Turkestan, the wild apple, almond, plum (uruk), apricot (caragach), etc., are commonly found.

The Transcaspian Forests. - Finally a few words may be added on the species found in the fairly extensive but as yet scarcely explored Transcaspian forests. These forests play an important part in the Transcaspian district, as they keep the sands from shifting - that ever-present danger in a desert regionand help to form fertile oases. They also render possible cattle-breeding. A considerable proportion of the species growing in the forests are of the desert type, and similar to those occupying the Turkestan deserts, e.g. the saksaul, etc. In addition, the acacia occurs, here called suzem, and reaches a height of $2 \mathrm{I}$ feet with a diameter of 7 inches at the surface of the ground. About I,350,000 acres of the Transcaspian forests are situated in the hills, including those in the valleys of Murgab, Fedzhena, and along the smaller rivers in the rural 


\section{I42 FORESTS OF SIBERIA AND TURKESTAN}

district of Karacalin. In these hill-forests the archa (juniper) appears, and is often of considerable size, 58 feet high and 2 feet II inches in diameter at the surface of the ground. The mountain maple, noted for the hardness of its wood, also occurs. In the Merosk and Tedzhensk districts copses of pistachionut trees exist. On the banks of the rivers, which overflow in the spring-time, forests of poplars and tamarisks help to keep the banks stable, and are thus of considerable importance.

Having regard to the extensive area over which these Asiatic Russian forests are spread, it will be of interest now to glance briefly at the nature of the staff and present organisation and protection afforded to the areas. Up to January I, I9I2, the State forests were divided, for administrative purposes, into 192 divisions (lesnitchestva) under the control of 9 Boards of Agriculture and State Lands : viz. those of Tobolsk, Tomsk, Enessey, Irkutsk, Amur, Omsk, Turkestan, Uralsk, and Turgai. According to the estimate for I9I4, the staff of the local forest administration was to consist of 583 officials, namely 35 forest inspectors, 222 foresters, 68 assistants, and 258 forest guards-a staff which cannot be said to err on the liberal side, and will need a great deal of strengthening when the work of exploiting the forests is commenced on a large scale.

In addition it was laid down for I9I 4 that another I70 officials were to be employed on the work of exploring and organising the forests. These additional 
officials were to comprise 4 inspectors of forest organisation, I5 head-taxators, 45 under-taxators, and I06 surveyors.

With the above quite inadequate staff, even when supplemented by two to three thousand extra guards and fire patrols, the latter being, by the way, unpaid, it is not surprising that the protection it is possible to give the forests is very inefficient, and that one of the greatest dangers to which they are subject is fire. On the subject of fire, and the appalling damage it causes in forest lands, the people are apparently quite ignorant, and wilful incendiarism is as common as used to be the case, and still is in parts, in India. The points of greatest danger, the dry areas, are exactly those in which the forests have the greatest local value, because so scarce; e.g. in the Steppe region and parts of Turkestan and in some districts of the Tobolsk and Tomsk Governments a scarcity of wood is already being felt by the local population. The chief causes of fires are the burning of the dry grass in the hot season in order to get up an earlier crop of new young grass for grazing purposes with the arrival of the first rains. The fires are allowed to " run," that is, no effort is made to restrain them, and they spread into the neighbouring forests; the drier and more windy the weather, the greater the area of the latter consumed. Camp fires made by travellers and left alight after their departure are also a fruitful source of forest fires. Indian forest officers are well acquainted with this form of forest devastation, which was of annual occurrence throughout the afforested areas in India in olden times. A forest 


\section{I44 FORESTS OF SIBERIA AND TURKESTAN}

staff and careful organisation in the latter country have done much to mitigate this, the greatest enemy of the forests during the hot dry periods of the year.

When one finds that in these Asiatic Russian forests a single forest guard may be in charge, for protective purposes, of an area which runs from 30,000 to 250,000 acres of forest, there can be little real protection from fire save on paper. It is stated that recently, just before the outbreak of the war, larger sums were being allocated for the purpose of protection, and certainly in the interests of the community and the future welfare and prosperity of the country, for these forests are a very valuable, an increasingly valuable, property, expense should not be spared in ensuring their safety. As a result of the forest fires, which are said to rival those of Canada and America in size, considerable areas of country are covered with shrubs of little value or with grass and moss, the latter preventing the growth of young seedlings of fir and spruce, etc., which may germinate from seed fallen from the scattered trees standing on the area. The fires also seriously interfere with hunting, which forms an important trade in parts of Siberia. As long ago as 1774 the Government were awake to the serious nature of these fires, for in that year a law was passed forbidding " the burning of the forests in the Siberian Government in which the sable was hunted." With a staff inadequate to enforce the law it practically remained a dead letter.

Considerable progress has been made with the work of investigation into the resources of the large 
area of forest in Asiatic Russia, and more especially has this been the case in the Western Siberian region, in which we in this country are perhaps more deeply interested. A plan was drawn up by the Forest Department under which the exploration work was to be completed in the year I928. The object of this investigation work is to ascertain the distribution of the various species of tree over the different areas of forest, the approximate amounts and quality of the old mature timber standing on the ground, the proportion of woods of the younger ages in existence, and the amount of increment in wood being put on in the forests. For on this latter becoming known, it is possible to fix the amount of timber which can be safely cut out annually. In old primeval forests which have never been felled in, it is usual to find standing on the ground an excess of old growing stock, and it is desirable on all counts that this excess should be cut out before it decays and thus becomes valueless. The investigations of the forest areas being undertaken by the department aim at ascertaining as nearly as possible the amount of this old growing stock standing on the ground. The organising and exploration work carried out by a portion of the trained staff may be divided into two classes. Firstly, detailed and closer investigation work in the areas containing the more valuable and accessible forests combined with an enumeration, to a certain extent, of the growing stock standing on the ground, in order to ascertain the numbers of existing mature trees ready for felling. Work of this nature has been carried out in the Western Siberian areas. Secondly, work of the nature of 


\section{I46 FORESTS OF SIBERIA AND TURKESTAN}

flying surveys having for its object to ascertain the nature of the forests, species and relative abundance of each, with an approximate estimation of the proportion of old growing stock, and so forth. This work is simpler, not so accurate or expensive to undertake, and is applied to areas which for various reasons are not at present workable. The more detailed work of investigation and enumeration in the forests enables the department to fix the varying amounts of exploitable timber, i.e. the number of trees which can be felled yearly, and the information already compiled on this head for the great forests of Western Siberia has shown that there exists a very considerable excess of growing stock to come out.

In the Forest Department Report for the year ending January I, I9I2, out of the total area of $624,000,000$ acres of State forests, 8,300,87I acres had been subjected to the detailed investigations, and $67,914,917$ to the operations of the flying survey, giving a total of $76,215,788$ acres, or about I2 per cent. of the whole forest area. But the work, with the increased estimates sanctioned, has since proceeded at a greater pace, with the result that an area of $44,055,900$ acres was subjected to detailed or partial investigation in I9I2 and I9I3, and $22,182,200$ acres in I9I4. By the beginning of I9I5 the Department had organised either by detailed or partial investigations an area of $143,100,000$ acres, or approximately one-fourth of the total area of the State forests in Asiatic Russia. A good and most useful piece of work. 
Other directions in which calls will undoubtedly be made upon the scientific abilities of the forest staff will be the necessity for grappling with the planting of the great sandy wastes which have resulted from the destruction of forests in the past, and which now threaten to engulf valuable agricultural lands. This problem is already receiving considerable attention in European Russia, as has been shown in a previous article. It will certainly demand skilful treatment in her Asiatic dominions.

From the descriptions already given of this great area of forests, it will be realised that they form a source of immense wealth, a wealth which for the most part is as yet untapped. It has been shown that in the drier parts of this tract the percentage of forest is very small, and that in these regions, owing to the bad treatment, in former times, of such forest as there was, it is now reduced to small areas insufficient for the requirements of the population. But although this is true enough in the case of the Governments or parts of Governments concerned, e.g. the Steppe region and Turkestan, it does not apply to the bulk of the great forest areas. These, in spite of fire, in spite of the war waged against them by man either for the purpose of extending agriculture, or from thoughtlessness, ignorance, or for the mere pleasure of being wastefully extravagant-in spite of all they have suffered in the past and suffer at the present time, these forests still cover an enormous extent of country, and contain a vast amount of unexploited timber and other forestry materials. In the past the conditions which would have enabled them to be 
worked or which would have justified their being exploited-to wit, favourable communications and a demand-have been absent. The forests have been for the most part untouched. For instance, according to the framed estimates in I9II, no less an amount than $I, 800,750,000$ cubic feet of timber were available for sale from the State forests. Of this amount I7I, 500,000 cubic feet only were disposed of, or something under Io per cent. In some parts as, e.g., in the Government of Enessey, the percentage sold was as low as $5^{\cdot} \mathrm{I}$.

As has been shown, the population is very sparse, and in many parts owned areas of forest sufficient for its requirements, and so had no reason or necessity for having recourse to the State forests. Of export trade until recently there was none.

There appears to be little doubt that one of the chief sources of the wealth of Asiatic Russia will be found in its forests, and will be reflected in its export trade. Already such a trade has developed, and these forests are taking a place in the international timber markets of the world. Up to the outbreak of the Great War, Russia's chief competitors in the timber markets were Austria-Hungary, Sweden, and Norway, and the United States and Canada. Already, however, Russia was looking to taking a bigger place in the competition with her rivals, and so far as Great Britain was concerned, she out-distanced them all, since we took about 35 per cent. of our total imports from Russia. To maintain the position in the markets she has already acquired, and the greater one she must inevitably take in the future as the exports from her rivals diminish 
with the cutting-out of accessible stocks, Russia will have to draw upon her vast Siberian forests. When all is said that can be said on the subject of past destruction and so forth, they remain, if not inexhaustible, at any rate of so vast a size that with proper management they should prove an extremely valuable asset and serve Russia's purpose for many years to come.

The fact that facilities for the export of timber from these areas are bad or totally wanting has been already alluded to. A certain amount of wood from the Tomsk and Tobolsk Governments has been exported within the last few years via Archangel and Petrograd, but the material requires to be first class to pay for the long transit. The following illustration on the subject of export difficulties places the present position in this respect in a nutshell :

The export of wood by the rivers $\mathrm{Ob}$ and Enessey, i.e. by water carriage, would enormously facilitate and promote the timber trade in the Governments of Tobolsk, Tomsk, and Enessey. Some ten or twelve years ago an attempt was made by a private agency to export timber from the Enessey district to London, but it ended in failure, although a considerable portion of the timber did reach Galchika, a village at the mouth of the Enessey river. The late General Makaroff undertook to place the timber on the steamer for shipment to England, but his attempt was thwarted, as ice prevented the ship from entering the mouth of the river. A few years later a flotilla of ships, equipped by the Ministry of Ways and Communications, succeeded in entering the Enessey, but were unable to 


\section{I50 FORESTS OF SIBERIA AND TURKESTAN}

return the same year and had to winter there. The steamer on which the famous traveller, Fritiof Nansen, arrived in Siberia in I9I3 also succeeded in entering the Enessey river. Thus it has been proved that it is possible for ships from the west to enter the Enessey river. But this is not sufficient. The timber markets of Western Europe would require the organisation of a regular service of timber steamers plying during the open season. Only with such a service would it be possible to undertake fellings on a large scale and the conversion of the material in saw-mills ready for transport to the western markets. As sawn or otherwise prepared timber cannot be kept lying up indefinitely without risk of spoiling, in the absence of guaranteed export facilities merchants have not in the past been ready to risk their capital in this business. The war has considerably altered the position, however, and there is little doubt that these rich Siberian forests will be able to furnish very considerable supplies of the timbers which, at the close of the war, will be so largely in demand.

Owing to the absence of waterways and railways, the timber export trade from the forests of Turkestan is as yet wholly undeveloped. Until comparatively recently, walnut, on account of the beautiful patterned veneer the burrs yielded, was exported in considerable amounts from Turkestan to Western Europe. The demand for the veneer has, however, fallen off of late years, and the considerable profits of yore have dwindled. Vast and valuable forests are to be found in the Irkutsk Government and the Transbaikal and Yakutsk districts, but owing to the absence of con- 
venient waterways no exports of timber have yet been made from this centre.

As regards the forests in the Far East, the export problem is far less complex. The Amur and other rivers flow through the country into the Pacific, thus affording cheap communication by waterway. Owing to this fortunate position, a great and increasing export trade in timber from the Pacific ports has developed. According to statistics issued by the Vladivostok bureau, the timber exports from Vladivostok in rgro amounted to 6,446 tons, increasing to I5,3I0 tons in the following year. The more valuable kinds of timber exported go to Western Europe, chiefly to Great Britain, whilst the inferior kinds are taken by Japan and China. In the same year about II0,000 cubic feet of cembran pine and spruce wood were exported from Ferney Bay to Australia, and from the Gulf of St. Olga 374,000 cubic feet of mine props. In the same year exports were started from Pasietta, about I00,000 cubic feet being sent away. With this extensive and rich area of forests at their back, a very considerable and valuable export timber trade is likely to develop, and we should make it our business in this country to become thoroughly acquainted with it, and ascertain exactly what classes of timber and what amounts it will pay us to secure from this region to supplement supplies obtained from Russia in Europe, Finland, and Western Siberia. China will not interfere with the supply of our demands. China is a large consumer of timber, and Russia in this quarter have their eyes upon the Chinese trade. Mr. Wilks investigated 


\section{I52 FORESTS OF SIBERIA AND TURKESTAN}

the Chinese timber market in IgII, and his figures showed that about $16,000,000$ roubles' worth of timber, in the raw state and converted, was imported into China, the greater part being supplied by Japan and the United States. With better organisation, however, it should not be difficult for the Amur region to compete with the above-mentioned countries, more especially as the Chinese market is not particular about the quality of its timber, cheapness being the first desideratum in the eyes of the Celestial. Secondor third-class timber, and even the material obtained from the crowns of the trees, the " tops" of the forester, is said to be good enough for this facile market. Certainly no more convenient market could exist, since it should enable the forest officer to clear his forests of all inferior material, and get paid for doing so into the bargain-a most enviable position.

Apparently the greatest difficulty to be faced in organising the Amur timber trade is the labour one. The State, for various reasons, has set limits to the employment of Chinese labour, and owing to the sparse population it is extremely difficult to obtain Russian labourers locally. The heavy expense connected with importing labour from great distances makes a large hole in the profits from the timber business. It is anticipated that this difficulty will disappear, as, owing to the rich nature of the Amur district, the population is likely to increase rapidly.

The revenue obtained from the State forests of Asiatic Russia is as yet insignificant when compared with their unquestioned value. As we have shown, the forests have been scarcely touched as yet. 
The total profit for the three years I9I0-I9I2 was as follows :

Year.

I9IO

IgII

IgI2
Roubles.

- $4,234,000$

- 4,079,000

- $4,259,000$

The profit from the forests varies in different districts, as would be expected, since in areas like parts of the Steppe region we have seen that wood is of comparatively high value. For instance, in IgI2 in the Akmolin district the better-class forest soil gave a return of 33 kopeks per acre, whereas in the Tobolsk Government it was just under 2 kopeks per acre, and in Tomsk about $2 \frac{1}{2}$ kopeks. In other forest divisions in the Tobolsk Government where exploitation is easier, the profit is higher, amounting to $55 \frac{1}{2}$ kopeks per acre of good forest soil.

Such profits, however, from fine forests containing large amounts of over-ripe timber, strongly emphasise the backwardness of the areas in communications and export facilities. With the extraordinary enhancement of timber prices which the war has brought about, and which its termination will not see lowered unless very careful steps are taken, there should be a considerable future before these valuable forests of Asiatic Russia, especially in Western Siberia and in the favoured Amur region. 


\section{$\mathrm{XI}$}

THE CEDAR (CEMBRAN PINE) TRADE OF ASIATIC RUSSIA

WHEN considering the Siberian forests from the standpoint of their trade value and as a source of income to the Government, it will be necessary to glance briefly at the important "Cedar" trade as it is called, i.e. the collection and sale of the seed of the cembran pine (Pinus cembra). The trade is a local one, but contributes greatly to the welfare of the local population, as the seed is widely eaten throughout the Russian empire.

The pine is widespread throughout Asiatic Russia, the Pinus cembra being the commonest species; on the Altai and Sachalin, however, the P. cembra var. pumilla occurs. Both trees produce the edible seed so well known and valued in the Russian market.

The trade in this commodity is chiefly carried out in the Governments of Tobolsk, Tomsk, and Enessey, and especially on the Altai, where there are still beautiful and as yet untouched pine forests and groves. In other parts of Siberia the cembran pine forests have suffered as badly from fire and the axe as has been the case with the other species-spruces, firs, larch and so forth.

The gathering of the seed of the cembran pine, or 
"the cedar harvest" as it is called, commences about the middle of August. At this period the local population and the "cedar" merchants proceed together to the cembran pine woods and groves to collect the seed. The method of collection, as also the tools used, is most barbarous and would appear to inflict the maximum amount of damage to the trees from which this source of profit is derived, and whose preservation, it would be thought, should be the first object of the harvesters. This is a common characteristic of the Asiatic races. In North Baluchistan and in Southern Afghanistan a pine known as Pinus Gerrardiana, the chilgoza or silver-barked pine, occurs in small forests clothing the steep mountain sides and crests. The seed from the cone of this pine is collected for sale, and is widely eaten throughout the Punjab. The methods in force in collecting it, as will be shown, have a curious parallel with those used in harvesting the cembran pine seed in Asiatic Russia. The tools used in Siberia are extremely primitive, consisting of axes, sieves, bark ladles, graters for the cones, mallets, poles, bags, etc. The gathering of the cones is effected by climbers-men and boys who climb up into the trees and knock or pull the ripe cones off the branches. As these branches also contain the young cones of next year's crop, the primitive methods of harvesting usually result in a number of these being knocked off in addition to the ripe ones, thus diminishing the harvest of the following year. This method of collection usually results in numbers of branches being broken off the trees, their future bearing capacity being permanently reduced. 
But worse damage than this, serious as it is, takes place. " Rather often," as it is expressed by a Russian writer on the subject, "wholly inadmissible and barbarous methods are employed, whole trees being cut down or large branches cut off." The folly of thus "killing the goose" must seem incredible to those who have no acquaintance with the peculiar point of view of the wilder and ignorant portions of the Asiatic peoples. The cones are collected and placed in bags by old men, women and children, and are carried to the camp where the cedar merchants have made their temporary headquarters, or taken direct to the village. The extraction of the seeds from the cones is now undertaken. For this purpose the cones may be simply dried, when the scales open and the seeds fall out, or the latter are extracted by means of a grater and a roller. The seeds are then sifted by being passed through a coarse sieve and winnowed in the wind. The seed, if these processes have been carried out by the collectors themselves, is then disposed of to the buyers-the cedar merchants-who themselves under take the further operations of cleaning and drying it. The drying is done throughout the autumn, and the seed is then stored. The merchants usually build and own barns and store-houses in which to store the dried seed as conveniently adjacent to the pine forests and groves as possible. On the Altai there is a large centre of this nature in the Bezelbeke meadow not far from the confluence of the Hara and Sasacockshee. In the following January the seed is taken from the store-houses and dispatched by the buyers to the various markets. 
It will be of interest to contrast the above method of collecting and dealing with the seed with that in force in the wild border land of North Baluchistan, Afghanistan, and the frontier to the west. The seed is collected by the tribesmen of these parts, who regard it as a right, and in fact consider the forests to be their own property. They fully recognise the value of refraining from felling the trees, except when absolutely required to obtain timber for building purposes, etc., but their regard for the trees goes no farther. The forest has an extremely ragged appearance, and this is in part due to the methods of collection, this work being carried out in the summer time. To obtain the seed, men climb the trees, and by means of long poles to the end of which a hook is affixed, they wrench from the boughs the seed-bearing cones. The wrench invariably breaks a portion of the branch, with the result that a tree from which the cones have been recently stripped bleeds from numerous places, and is in a condition most susceptible to attack by insect and fungus pests. The attention of a Political Officer of these regions was drawn to the fact that, owing to the greed of the tribesmen, in addition to the injury done to the trees scarcely a cone was left upon them to produce seed for the natural regeneration of the forests, i.e. the production of a new crop of trees. This must be an equally vital point in the parts of the Western Asiatic forests which are subject to the collection of the seed of the cembran pine. In the case of the chilgoza pine the cones after collection are gathered together in heaps, and the heaps fired whilst 
the cones are still green. The heat forces open the cone scales, and the seed is then picked out. This is the common procedure adopted, and when marching through these forests in the autumn, heaps and mounds of empty cones collected in the centre of some small glade are often met with.

At the request of the Political Officer, a note was prepared laying down some simple rules for the improved collection of the cone harvest in the interests of the preservation of the trees themselves. We had a solemn jirgah in the forest one day. The heads of the local villages and so forth attended and received the explanations of the proposed future procedure with no great enthusiasm, but with promises to see that it was carried out. They are childishly difficult, not to say dangerously difficult, people to deal with in these parts, and as they burnt down the Political Officer's summer head-quarters rest-house, situated in these forests, the following year, it is to be feared that the rules for the collection of chilgoza cones have not yet been introduced very effectively.

To return to the cembran pine of Asiatic Russia. The yearly collection of seed is said to amount to several tens of thousands of poods (I pood equals $32 \mathrm{cwt}$.), the average wage of each workman being from six to nineteen roubles a season; or when the work is undertaken by the Labourers' Association (artel) each member of the Association who takes up the work makes from thirty to forty roubles during the season.

As a popular dainty the cembran pine seed is much appreciated both throughout Siberia and European 
Russia. The seeds also yield the "cedar" oil. To obtain it the kernels are extracted from the seed, the husk being stripped off, and ground into a powder. The powder is put into pots covered with water, and placed in slightly heated stoves. The oil from the seed rises to the surface and is poured off into vessels ready for use.

It has been necessary to glance briefly at this trade in the seed of the cembran pine since it naturally affects the exploitation of the forests of this species as also the felling arrangements in mixed forests containing this pine in any abundance. A tree which has a value other than for its timber alone owing to the fact that it produces a minor product of marketable value in addition to the major one-timber-must necessarily be subject to a different form of treatment to that applicable to the purely timber-yielding species. And this fact has to be borne in mind when considering the exploitation of the Pinus cembra woods of Siberia and their possibilities as regards supplying material to the timber markets of Europe. 


\section{PART III \\ TIMBER SUPPIIES AND THE WAR}

\section{XII}

TIMBER SUPPLIES AND THE WAR ${ }^{1}$

\section{IMPORTS IN I9I3}

For a considerable number of years past the possibility of the occurrence of a wood famine has been discussed-a famine, that is, unprecedented in the history of the world. Many have scouted the idea of such a proposition as a fantastic chimera, pointing to the vast forest resources still existing on the surface of the globe. Others, with a more intimate knowledge, perhaps, of the real position of affairs, have persistently sounded the note of alarm. They have drawn attention to the enormously increased demand for forest produce of all kinds which the past half-century has witnessed; to the great destruction of forests which has taken place in the opening out of the countries of the New World during the same period; to the wasteful and extravagant utilisation of these

1 This article was written in September I9I4, and published in The Ninetsenth Century and After in February 1915. 
resources largely through fire by an ignorant population allowed to pursue its own way by an apathetic Government; and, finally, to the fact that the markets of the world have for some time been supplied with large quantities of material at a low and more or less fictitious price-material that was easily accessible, which paid, for the most part, a very small royalty or none at all-material, in other words, which had cost man nothing to produce and therefore could undersell in every country a similar article which had been grown by man himself. True, in this country we had our own special troubles. A better class of material than we had produced in the past in our own woods on soil and in a climate at least as favourable as that from which the imported articles came, easily ousted the home-grown produce, the position being aggravated by the high railway freight rates in force in these islands.

Amongst European States, of course, the importance of the forest received recognition several centuries ago, as soon, in fact, as the pressure and needs of the growing population came to be felt upon the forest lands. These were only saved by closure and the enactment of forest laws protecting both State and privately owned woods. With the increase in population came the timber market, the enhanced value of forest products, and the raising of new crops to take the place of those felled over for sale. But this recognition of the value of forests was confined to Europe or the more densely populated parts of it. Elsewhere wasteful utilisation held sway. Gradually, however, expert opinion in this matter during the 
latter part of last century came to receive a certain meed of attention from the Governments of the States of the world. One of the more recent and notable recognitions took place in America under the Roosevelt régime. That great and far-seeing statesman studied the question, became convinced of its importance, and set himself to put a stop to what may be said to have been one of the most notorious instances of wasteful utilisation of forest material in any country. Roosevelt took up the question in his own vigorous fashion, preached the conservation of the natural resources of his own country, helped to create a Bureau of Forestry, and by all the means in his power encouraged a forestry opinion and a forestry knowledge amongst the people. The crusade resulted in the creation of large forest reserves, in large plantings, and the enlistment of the great lumber interests in checking forest fires, which were imperilling the future material prosperity of the nation, and in replanting areas they had felled over.

The energetic action of America in the direction of forestry caught first the imagination and then the attention of the world. Outside Europe, India, long years before, had recognised the importance of conserving her vast forest area, and under that able administrator, Lord Dalhousie, a permanent policy for forest administration was laid down in I855; a work which, subsequent to the Mutiny, with its immediate after-result of rapid railway building, was to be greatly accelerated by the formation of an Imperial Forest Department. But India does not advertise. The officials carry on their work in an almost total 
obscurity so far as the outer world is concerned, and it was many years before the existence of the fine Indian department was to win recognition throughout the world, or even within the British Isles. Many British Colonies-notably the Cape and Canada-soon followed the Indian and American lead, in many instances borrowing men from India to start their forestry work or advise in the matter. At the present day most of the British Dominions, Colonies and Protectorates have a forestry department in being or are laying the foundations of one. In other words, the conservation of their natural forest resources in the interests of their present and future populations has become a recognised branch of the administration of all States, although in many cases much remains to be done before such administration can be considered efficient.

Turning now to our own country, the British Isles may be said to be the last to enter the arena of forest production and conservancy. Not that forestry as a science and a source of revenue had not been pursued for a long period in this country. It had! But the position has been far different from that existing on the Continent of Europe. These islands started, as did many other now densely populated parts of the world, with primeval woods covering the greater part of them. These, with an increasing population, were mostly wantonly wasted by fire and axe, considerable areas formerly covered with pine remaining bare at the present day, witness the Scottish Highlands. The areas still under wood-such as, e.g., the New Forest in Hampshire and the Forest of Dean in Gloucester- 
shire-owe their preservation to the fact that they were maintained as Royal shooting forests in the olden days. But forestry, in areas of privately owned woods, was understood in England and dates back a long way. In I543 a Statute of Woods was enacted. Under this it was decreed that all woods should be enclosed for four, six, or seven years after each cutting over of the coppice for different rotations, and that at least twelve standards per acre should be reserved or left on the area to grow into timber of a certain girth or age. These standards were to be oak, if possible, or elm, ash, aspen, or beech, these being the timbers most in demand, whilst the coppice consisted of chestnut, hazel, ash, oak, willow, birch, etc. The object of this and subsequent enactments was to ensure the maintenance of a supply of suitable timber of the requisite size for shipbuilding, both for the Navy and the merchant-vessel classes. The success which attended Evelyn's planting campaign in the reign of Charles II has been commented upon. This practice of forestry, which came to be known as British forestry, remained in force for a long period, and supplied the country with the bulk of its timber requirements in the direction of home-grown materials. It was successful as long as, and only as long as, it had its home market. The introduction of the steel vessel, the abolition of the import duties on Colonial timber in 1846 , and for all other foreign timber in I866, sounded the death-knell of British forestry methods as at the time practised. And not only this. These methods unfortunately came to be positively injurious. The requirements of the old shipbuilding 
trade necessitated the production of large branches, crooks, and curved timber on the trees. In order to produce these it was essential that each tree should be given a great deal of growing space, the result being loss of height-growth, short bole, and large branches. As soon as these latter no longer found a market for which they were grown, forestry operations resulted in a loss, the only saleable part of the tree being the bole, of greatly curtailed length. This was bad enough, but worse was to follow. Plantations were formed of other species, especially conifers, to which the old principles and methods of thinning were applied, or something having a close resemblance to these old methods. Consequently the new woods were systematically over-thinned, the trees branched low, the bole was stunted and full of knots, the volume of timber realised per acre was much below what it should have been-all witness to the impracticability of applying a perfectly correct sylvicultural system for one class of material to the production of a different one. The results of the past half to three-quarters of a century have not been due so much to a decadence of British forestry as to an unfortunate want of knowledge of the methods to be employed to produce the classes of material imported in large quantities from the Continent, classes which have easily and successfully competed with the home-grown article. A golden opportunity would now seem to have arrived to rectify matters.

With this brief summary we will now turn to a survey of the present production of forestry materials (timber, pit props, and wood pulp, and so on) and 
their imports into this country from various parts of the world. It will then be possible to consider the position, so far as forest imports are concerned, in which the sudden incidence of a general European War has placed us. It will be pointed out how, whilst helping to the utmost extent of our resources the mineowner, builder, and other trades employing wood, an admirable opportunity has arrived for clearing off a number of wrongly formed and badly grown plantations and of starting afresh. A study of the imports for I9I3, which will be now proceeded with, will sufficiently support this contention.

The United Kingdom buys nearly half the timber exported from all countries, and the prices ruling in British markets affect the world! With a war of the present magnitude on our hands this state of affairs appears worthy of some consideration. An investigation of the Board of Trade Returns for I9I3 shows that the value of wood and timber and manufactures thereof imported into this country amounted for that year to $£ 37,300,000$, as against $£ 25,600,000$ in I909. For the same years the value of imported wood pulp, including millboard and wood-pulp board, was $£ 5,425,000$, as against $£ 4,135,000$. The rise in each case over a period of four years only is noteworthy. The chief exporting countries in Europe are Russia, Sweden, Norway, Germany, France, and Austria-Hungary, the three first being the most important. Outside Europe the United States of America and Canada send us large amounts of wood material. 
The chief supplies of fir (coniferous wood-hewn, sawn, and planed-other than pitwood) come from Russia, Sweden, Norway, Germany, United States, and Canada, the total values of the imports from these countries for I9I3 being $£ I 6,000,000$ from Europe and $f 6,500,000$ from the United States and Canada. The Russian imports were $£$ I0, 330,000, as against a total of $£ 5,700,000$ from Sweden, Norway, and Germany, the totals from the United States and Canada being $£ 3,383,000$ and $£ 3,150,000$ respectively.

Russia again is the chief pit prop and pitwood supplier, $£^{2}, 400,000$ worth of this essential commodity for the mines of the country being imported in I9I3 (as against $£ I, 400,000$ in I909, an increase of a million!). The next important supplies came from France, $£ 830,000$; Sweden, $£ 560,000$; Portugal, $£ 280,000$; and Norway, $£ 200,000$; Germany, Spain, and other foreign countries sending together $£ I 54,000$. No pitwood came from British possessions during I9I3. The importance of the position revealed by these figures can scarcely be exaggerated.

Wood pulp, of which a shortage has probably already made itself felt, to judge from the dwindling in size as also in quality of the paper in use by many of the daily papers and the weekly and monthly periodicals, is shown in the Board of Trade I9I3 Returns under five heads: Chemical dry, bleached and unbleached; chemical wet; mechanical dry and wet. Of the first named, Norway is the largest importer into this country ( $£$ I36,000 in I9I3), with $£ 23,000$ from Sweden. The largest amounts of unbleached came from Sweden (£I,945,000), Norway $(£ 377,000)$, Russia $(£ 329,000)$, 
and Germany $(£ 322,000)$. Chemical wet came chiefly from Sweden $(£ 37,000)$, mechanical dry from Russia $(£ 22,000)$, and mechanical wet from Norway $(£ 701,000)$, Sweden $(£ 28 \mathrm{I}, 000)$, Canada $(£ I 56,000)$, and Newfoundland $(£ \mathrm{I} 23,000)$.

The greatest quantities of oak in I9I3 were imported from the United States ( $£$ I I I34,000), Russia ( $£$ I 86,000$)$, Germany and Austria-Hungary $\left(\ell_{2} 73,000\right)$, and Canada $(£ 85,000)$. The chief amounts of teak came from India $\left(f_{752,000)}\right.$, Siam ( $\left.f_{\text {II }}, 000\right)$, and Java $(£ 40,000)$. The mahogany came from French West Africa $(£ 344,000)$, Southern Nigeria $(£ 226,000)$, Gold Coast ( $\left.f^{I} 98,000\right)$, British Honduras ( $\left.£ I 35,000\right)$, United States ( $\ell_{\text {II } 5,000)}$, Cuba $(£ 72,000)$, and German West Africa $\left(£ 5^{2,000)}\right.$. The largest amount of furniture and cabinet ware came from France $\left(f_{1}\right.$ I06,000) and the United States ( $£ \mathrm{I04}, 000$ ), with $£ 600,000$ from Germany and $£ 58,000$ from Belgium. House-frame fittings and joiners' work came from Sweden $(£ 7 I, 000)$ and the United States $(£ 40,000)$. Wood ware and wood turnery from the United States $(£ I, 392,000)$, Russia ( $£ 806,000)$, Germany $(£ 364,000)$, Sweden $(£ 85,000)$, France $(£ 70,000)$, and Canada $(£ 53,000)$. The chief imports of staves were sent from Russia $(£ 481,000)$, United States $(£ 266,000)$, Sweden $(£ I 20,000)$, Germany $(£ 64,000)$, Norway $(£ 46,000)$. Chip boxes to the value of $£ 38,000$ were imported from Sweden, and half a million pounds' worth of matches from Russia ( $£ 21,000)$, Sweden $(£ 292,000)$, Norway $(£ 38,000)$, Netherlands $\left(£_{22}, 000\right)$, and Belgium $(£ \mathrm{I} 34,000)$. Cork to the tune of $f 895,000$ was imported from Portugal and Spain. 
Turning now to the classification of timbers. In commerce timbers are classified into two chief groups: softwoods and hardwoods-a purely arbitrary classification. The former are practically all conifers, pines (red and yellow deal), spruces, and firs (white deal), and the larches. The timber of these species is comparatively light, strong, and easy to work, and is extensively used by all trades, and generally for building purposes. Coniferous timber is imported as logs, deals (thick planks), and boards. It is logged and sawn up from selected well-grown clean stems, free as possible from knots. Pit-props are cut from thinnings in middle-aged woods, from the tops of older trees which have been logged, and from stunted growth which will yield material of the requisite size. Wood pulp is preferably made from trees of 4 -inch to 8-inch diameter, and is largely used, of course, for the manufacture of the cheaper classes of paper. With the exception of oak and a few other species, the imported hardwoods do not grow in these islands. Even in the case of oak the foreign timber of this species is preferred to the indigenous, as it is less hard and easier to work. The foreign imported hardwoods are used for veneering, panelling, flooring, furniture, and wood turnery, etc. They are usually heavy woods and difficult to work, and consequently more costly.

The imports of wood and timber received into this country may be divided according to the Board of Trade Returns into six divisions as follows, taking hewn (i.e. logs) and sawn, planed, and dressed coniferous material as one division: 


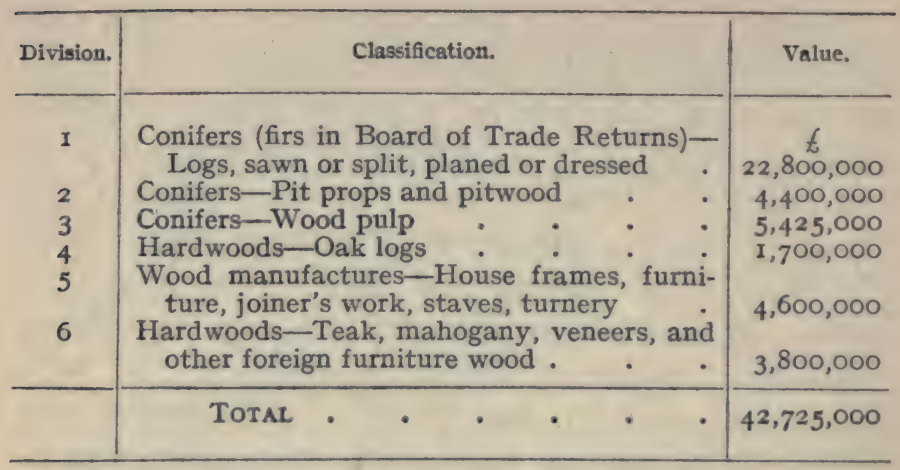

An analysis of the above six divisions of the imports of wood and timber into this country brings into prominence several important and interesting features. The first four, involving a sum of $£ 34,325,000$, comprise materials obtained from coniferous species and oak, all of which can be grown in this country. For the manufactured articles in division five both conifers and hardwoods are employed, the sixth division being confined to purely foreign exotic timbers. A second point is the steady rise in the imports under all the divisions during the past four years, the increase for I9I3 over I909 being nearly $£ 12,000,000$. From the above rough classification it can be seen that the pinch is likely to be early felt in the imports of pitwood, wood pulp, and building timbers. It will be useful, therefore, to tabulate the amounts of materials in our divisions coming from the various countries. These latter may be divided into three distinct categories of States: (I.) European; (II.) Non-European States and Foreign Colonies; (III.) British Possessions, including Protectorates. 
VALUES IN STERLING OF IMPORTS UNDER THE DIFFERENT DIVISIONS

\begin{tabular}{l|c|c|c|c|c|c}
\hline Drv. I & Drv. 2 & Drv. 3 & Drv. 4 & Drv. 5 & Drv. 6 \\
\cline { 2 - 4 } & $\begin{array}{c}\text { Conifers: } \\
\text { Iogs, } \\
\text { Sawn,split, } \\
\text { planed. }\end{array}$ & $\begin{array}{c}\text { Conifers: } \\
\text { Pit props } \\
\text { and } \\
\text { Pitwood }\end{array}$ & $\begin{array}{c}\text { Conifers : } \\
\text { Wood } \\
\text { pulp }\end{array}$ & $\begin{array}{c}\text { Hard. } \\
\text { woods : } \\
\text { Oak Logs }\end{array}$ & $\begin{array}{c}\text { Wood } \\
\text { Manufac- } \\
\text { tures : } \\
\text { Furni- } \\
\text { ture, \&c. }\end{array}$ & $\begin{array}{c}\text { Foreign } \\
\text { Hard- } \\
\text { woods. }\end{array}$ \\
\hline
\end{tabular}

\section{Imports from Europe.}

\begin{tabular}{|c|c|c|c|c|c|c|c|c|}
\hline Ru: & - & & $10,4 I^{\frac{\hbar}{t}} 6,000$ & $\underset{2,4 I 5,000}{E}$ & 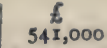 & 186,000 & $\stackrel{f}{f} \underset{1,299,000}{ }$ & $\underset{I I 7,000}{6}$ \\
\hline & - & • & $3,910,000$ & 560,000 & $2,492,000$ & - & 317,000 & \\
\hline & - & & $I, I 43,0$ & 200,000 & $\mathrm{I}, 26 \mathrm{I}, 000$ & - & 86,000 & - \\
\hline any, & & - & 680,000 & 53,000 & 460,000 & 134,000 & 509 & 37,0 \\
\hline & & - & 45,000 & - & 13,000 & & $6 \mathrm{I}, 000$ & 10,000 \\
\hline Belg & - & $\bullet^{\circ}$ & - & - & $\div$ & - & 77,000 & - \\
\hline & - & - & 55,000 & 830,000 & 6,000 & - & 187,000 & 55,000 \\
\hline & & - & & 278,000 & r5,000 & 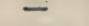 & & \\
\hline atria-H & & - & 5 & 91,000 & - & $\overline{-}$ & 31,000 & \\
\hline ustria-H & & & 5,00 & & - & & & \\
\hline
\end{tabular}

II. Non-European Stales and Foreign Colonies.

\begin{tabular}{|c|c|c|c|c|c|c|}
\hline \multirow{2}{*}{\multicolumn{7}{|c|}{$\begin{array}{c}\text { German } \\
\text { Africa }\end{array}$}} \\
\hline & & & - & 一 & - & 52,000 \\
\hline Possessions & 一 & - & - & - & - & 52,000 \\
\hline French West Afric & - & - & - & 一 & - & 344,000 \\
\hline Siam . - & 一 & 一 & - & - & - & 119,000 \\
\hline Japan & $\overline{0}$ & - & - & 57,000 & II, 000 & \\
\hline United States & $3,3^{8} 3,000$ & - & 29,000 & $\mathrm{I}, \mathrm{I} 34,000$ & $x, 802,000$ & $1,019,000$ \\
\hline Cuba . • & - & - & - & - & - & 89,000 \\
\hline Nicaragua & - & - & - & 一 & - & 22,000 \\
\hline Mexico & - & - & - & - & - & 9,000 \\
\hline Domingo & - & - & - & - & - & 23,000 \\
\hline
\end{tabular}

\section{British Possessions (including Protectorates).}

\begin{tabular}{|c|c|c|c|c|c|c|}
\hline $\begin{array}{l}\text { Gold Coast } \\
\text { Southeru Nigeria }\end{array}$ & E & $=$ & - & $=$ & $=$ & 198,000 \\
\hline $\begin{array}{l}\text { Southeru Nigeria } \\
\text { India }\end{array}$ & $=$ & $\overline{-}$ & $\overline{-}$ & $=$ & & 226,000 \\
\hline Ceylon : & - & - & - & - & $\underline{7,000}^{-}$ & 752,000 \\
\hline British North & & & & & & \\
\hline $\begin{array}{l}\text { Borneo } \\
\text { Australia (including }\end{array}$ & - & - & 一 & 一 & - & II, 000 \\
\hline Tasmania) & - & - & - & - & - & 243,000 \\
\hline New Zealand & 11,00 & & - & & - & \\
\hline $\begin{array}{l}\text { Canada } \\
\text { Newfoundland : }\end{array}$ & $3,150,000$ & - & 265,000 & 85,000 & 71,000 & 94,000 \\
\hline $\begin{array}{l}\text { Newfoundland } \\
\text { British W. India }\end{array}$ & & - & I 23,000 & & & \\
\hline Islands & - & - & - & - & 一 & 16,000 \\
\hline $\begin{array}{l}\text { British Honduras } \\
\text { British Guiana }\end{array}$ & - & - & 一 & - & - & 135,000 \\
\hline British Guiana & - & - & - & - & - & 55,000 \\
\hline Totals & $22,800,000$ & $4,427,0$ & $5,205,000$ & $1,735,000$ & 4,515 & $3,692,000$ \\
\hline
\end{tabular}

N.B.-The slight differences shown here from the lump sums quoted above are due to small additional entries in Board of Trade Returns under "From Other Countries " unspecified. 
Columns 2, 3, and 4 of this form are perhaps of greatest interest at the present juncture, since some important industries are dependent on the materials they deal with being available. Column I includes the bulk of the timber in general use by the building and other trades employing wood.-Approximately one-half of the imports of I9I3 are probably closed for the present. In column 2 about three-fourths of the pitwood imported came from Russia and France. Supplies from these countries are unlikely to be available for some months to come, probably at the earliest well over a year, since no fresh fellings are likely to be carried out till the men return from the Colours. ${ }^{1}$ About three-fifths of the wood pulp (column 3) comes from Sweden and Norway. Whether this material can be delivered must depend on North Sea naval problems. The United States, Canada, and Newfoundland should, in course of time, be able to help us here. To the United States and Canada we shall have to look for our supplies of oak, unless the trade will be content to use the harder but finer quality oak of these islands. As regards the $£ 4,500,000$ of wood manufactures, the present will be an excellent opportunity to ascertain how many of these articles we can produce in this country. In the foreign hardwoods only one-sixteenth comes from Europe. The command of the sea throughout the world should, therefore, enable supplies of these commodities, of

1 Since this was written the Board of Trade Returns for September 1914 show that 240,000 tons of pitwood were imported that month as against 600,000 , the normal amount for the month. The greater part came from France. 
which probably teak is the most important, to continue to arrive in our ports; provided always ships are available to carry them. The match producers in this country will not be sorry to secure the half million of money paid for imports of this article to these shores. Sweden, Norway, and the Netherlands could, however, maintain or increase their supply with a safe North Sea passage maintained for them. ${ }^{1}$

The area under woodlands and plantations in these islands is roughly about $3,030,000$ acres, as follows : England, I,666,000 ; Scotland, 879,000 ; Ireland, 303,000 ; Wales, 182,000 . With the favourable conditions of soil and climate of this country these three million odd acres should give an average annual growth or increment of 60-70 cubic feet of timber per acre, instead of about ro cubic feet, which is, roughly, the actual present average production per acre. Fifty cubic feet is the estimated average annual growth in Germany. As has been said above, the United Kingdom buys nearly half of the timber exported from all countries, and the prices ruling in British markets affect the world. It has been shown that at least one-half of the I9I3 imports of conifer logs and sawn and planed coniferous timber are at present closed to these islands, and to all appearances are likely to remain so for a considerable period of time. Also about three-fourths of the pitwood imports (coming from Russia and France) are lost to us. The supply,

1 This article was written in September I9r4. It is perhaps of some interest when the position of affairs a year and a half later is taken into account. 
so far as is possible, of these two classes of wood during the next few months, until more distant countries can come to our help, is the problem before us. That efforts will be made by countries farther afield to take advantage of this decrease in imports in the British market has already been evidenced by the offer of the Government of Newfoundland. It has already intimated its desire and intention to supply the pitwood market. For this purpose there are, it is understood, considerable areas of scrub and stunted material in the Colony on tracts formerly over-run by fires, which it is expected will be able to furnish considerable supplies of pitwood of the smaller sizes. America and Canada, who already send us well over a fourth of the imports of coniferous logs and sawn and planed timber, may increase this amount. This may, however, take time. The supply of imported oak timber will also be practically confined to the United States and Canada. It would appear, therefore, that in these three directions there is a great opportunity for home-grown material, material which, owing to a variety of causes, chiefly perhaps the rough knotty nature of the wood grown and the heavy railway freight rates, has not up to now been able to compete in the open market with imported material of the same species and class, but of better quality. For the figures of imports already tabulated emphatically prove that colliery-owners and others are no longer in a position allowing them to pick and choose. True, owing to our contracted exports to the countries engaged in war less wood materials may be required in these islands. But our imports are so vast, and the home 
supplies available so comparatively small, that there is no need to worry on that score. The important point is to get rid of our own inferior material, whilst at the same time giving a much desired support to the market, before more distant fields step in and once again cut out the home-grown. Incidentally the cause of scientific forestry in this country has all to gain by such action. How is this unique opportunity to be taken full advantage of ?

It has been shown that all the imported conifers of divisions $I$ and 2 can be grown in this country. The chief are Scots pine, spruce, larch, and fir. The first two are the pit-prop woods (In France and South Europe the Maritime pine is used.) Considerable tracts of Scots pine exist in this country. Of spruce, the available supply is, unfortunately, very small owing to the extraordinary neglect which this species has received at the hands of planters up to comparatively recent years. Larch for colliery purposes is only used in the main galleries owing to its greater cost. We have little fir growing, save as ornamental trees in policies and parks, and so on. With a heavy demand and restricted supply, however, we can reckon on colliery proprietors being prepared to take anything which will serve as a pit prop, provided it has fair straightness, the necessary strength, and is of the requisite size. There are plenty of scrub areas of oak and other species in the country, in parts of Scotland especially, grown up from the old oak coppice, which will furnish material of pitwood size. Such areas before the war were worthless, and in many cases would not, or scarcely, cover the cost of felling 
and replanting. Their opportunity has now arrived. It should prove possible to fell all accessible areas of this nature at a profit, provided the operation is undertaken in the near future and before other more distant supplies are placed upon the market. ${ }^{1}$ Thus, broadly speaking, it may be said that almost any area which is fairly accessible and has on it a crop of size and sufficient durability to produce pit props has at the present a market before it. Areas of older trees can supply logs and sawn and planed timber in addition to pitwood. Other hardwoods which will now be taken are chestnut, beech, birch, sycamore, elm, and alder.

It is possible to differentiate between the different classes of woods which may be utilised in this manner in the service of the nation, and to the advantage of the proprietor.

Taking first the Scots pine woods of Scotland. There are unfortunately considerable tracts of both middleaged and old woods which were very badly blown out in the great gales of November I9II and April I9I2. Other areas of middle-age and under have been badly opened out by snow-break and wind. Others, again, planted in unsuitable localities, have never fulfilled the anticipations formed for them, and already before middle age it is seen that they will require a very long rotation to produce timber of sleeper size. The opportunity for all these classes of woods is to hand, and there should be every prospect, if they are dealt with

1 It has already been shown in Article I, p. 8, that such areas are being felled in Perthshire (and elsewhere), the material being delivered on the Highland Railway at 18 s. per ton. Vide Pl. 8. These props are being sent to Newcastle.-E. P. S. May 1916. 
at once, of a profit being obtained from their sale and clearance.

The second class of woods for consideration are those from about thirty-five to fifty years old Scots pine, Scots pine and spruce, or with a few additional larch in mixture. These may have been grown to produce pit props, as in the instances at Raith (on a forty-year rotation) in Fife, or the original idea may have been to grow them on a longer rotation for large timber. It will be for consideration now whether it will be more profitable, and to the greater interests of the nation, to clear fell these areas and convert the material into pitwood.

It is unnecessary to consider here at any length the next class, old mature, or nearly mature, woods. With a good market their removal will be financially desirable.

The next class, from the scientific forester's point of view, is certainly not the least important. This consists of immature woods from about thirty years of age and upwards, in which thinnings can be made. In all accessible woods of any size, these thinnings should provide a considerable amount of pitwood material. The important point will be that the thinnings should be made with care, the trees to be removed being marked beforehand by a reliable forester well acquainted with the principles of scientific thinning.

Finally, for general purposes there are the few pure spruce, larch woods, and various hardwoods. Of pure spruce there are few in this country. Such as are available will doubtless be marketed at 
Little need be said here of larch. The timber always finds a ready market, and there will probably be an upward tendency in prices for this material. For oak high forest the scrub areas have been already dealt with-in the absence of the nearest supplies which come from Austria-Hungary and Germany there is likely to be a larger demand and a higher price. Birch may be in demand for furniture-making purposes, in addition to pit props,- as also our other useful hardwoods, to take the place of imported manufactures.

As to the size of the wood materials in demand. It will be unnecessary to dwell upon division I, logs and sawn timber. A few remarks may, however, prove useful on pitwood. The following is a quotation (abbreviated) for Scots pine and spruce pitwood drawn up in August I9I4 by a large colliery proprietor in Scotland. ${ }^{1}$ The classes are four in number-round props, quartered props, crowns, and pit sleepers; the prices are carriage paid, delivered at the mines.

Round props -3 in. up to $4 \mathrm{ft}$. in length fetch $3 s$. IId. per $100 \mathrm{ft}$. in $\frac{1}{3}$ in. classes, and varying lengths, to $5 \frac{1}{2}$ in. up to $8 \mathrm{ft}$. in length, fetching ros. $9 d$. per $100 \mathrm{ft}$.

Quartered props-Ex. 5 in., 6 in., and 7 in. up to $4 \mathrm{ft}$. long fetch 2s. $1 d$., $2 s .9 d$., and $3 s .7 d$. per $100 \mathrm{ft}$. respectively.

Crowns $-3 \frac{1}{2}$ ft. $\times 3$ in. $\times 1 \frac{1}{2}$ in. fetch $I d$. each.

$4 \mathrm{ft} . \times 3 \frac{1}{2}$ in. $\times 1 \frac{1}{2}$ in. fetch $I \frac{1}{d} d$. each.

5 ft. $\times 4$ in. $\times 2$ in. fetch $1 d$. each.

5 ft. $\times 4 \frac{1}{2}$ in. $\times 2 \frac{1}{2}$ in. fetch $1 \frac{7}{8} d$. each.

5 ft. $\times 5$ in. $\times 2 \frac{1}{2}$ in. fetch $2 \frac{1}{2} d$. each.

Pit-sleepers -3 ft. 3 in. $\times 5$ in. $\times 2$ in. fetch 15 s. 6 d. per roo.

The butt ends of trees are usually cut up into quartered wood, pit sleepers, small crowns, and hutch-boards.

1 The prices have since greatly increased. 
Of the amounts of timber and pitwood available in these islands to fill the gap made in the imports, it is not at present easy to speak. ${ }^{1}$ There is no forest law in this country, and therefore no power to compel the felling, in the interests of the nation, of areas of woods in private ownership, as is the case in many Continental countries. Nor is there any evidence that such a law would be necessary in Britain. The difficulty in the past has been to find a good market for the produce of the woods. With a market at the door there can be little doubt of the willingness and patriotic spirit of proprietors to take advantage of it. It has been estimated by one large Scottish colliery proprietor that he would require about 200 acres per annum of fair, well-grown Scots fir, forty to fifty years old, for his needs. And he further estimated the total Scottish colliery requirements at 6,000 acres of the same material per annum. It has not been stated whether the calculation is based on Continental methods of growth or on British ones-a matter of some importance, since the British woods as grown in the past carry far less per acre than is the case with the bettergrown woods of the Continent. The estimated average annual requirements would thus be probably nearer 8,000 acres per annum. And this is for pitwood alone!

In conclusion, there is one other point which may

1 Inquiries by the English Board of Agriculture, published in November 1914, on the subject of the amount of pitwood available in England and Wales estimate $7,900,000$ tons standing in the woods, of which $3,800,000$ tons could be exploited by extraordinary fellings. This would supply the demand for one year, the total amount available only supplying the requirements of two years. 
be briefly touched upon here, for it scarcely comes within the purview of matters herein considered. I allude to the labour supply. To work the woods in the country will almost certainly require a supply of imported labour, and provision will have to be made for the housing of such labour. Even so, this labour, or much of it, will not be satisfactory for the present emergency, which demands good and rapid work. At the present moment we probably have as fine a supply of well-trained forest labour as has ever been in existence in this country. It is to be found amongst the German prisoners. ${ }^{1}$ One-twelfth of the population of the German Empire is said to be connected in one way or another with the working of the German forests. There must be, accordingly, at the present moment amongst our prisoners men who are first-rate forestry labourers. It would appear possible that in this emergency some use could be made of these men, their services being remunerated. In thinning operations trained hands would be invaluable.

1 Also to a certain extent amongst the Belgian refugees. 


\section{XIII}

THE EFFECT OF SIX MONTHS' WAR ON THE TIMBER SUPPIIES

THE outbreak of the Great European War inevitably brought about an immediate and considerable dislocation to trade in all departments. That a war in Europe, even on a small scale, given that certain of the Great Powers were the belligerents, would result in such a check had, of course, been anticipated for years; but some of the direct causes for this diminution could scarcely have been foreseen. For instance, the shortage in freight steamers was perhaps not expected to the degree which has actually taken place owing to the large number of vessels taken up by the Government for military and naval purposes. The First Lord of the Admiralty told the House some months ago that a considerable portion of the British mercantile fleet was being so used. ${ }^{1}$ This action on the part of the Admiralty, whilst quite necessary, has resulted in a shortage of vessels which has had a direct bearing upon the shrinkage in imports both of timber and other produce of the forests-for shinkage there has been. Then, again, the removal from the ocean of Germany's entire mercantile marine, plying as it did on every sea, has naturally still further assisted

1 This article was written in February 1915 and published in the Nineteenth Century in July 1915. 


\section{I82 EFFECT OF WAR ON TIMBER SUPPLIES}

the depletion of cargo vessels, since so large a proportion are interned, and consequently unavailable for transport purposes.

That timber supplies as a result of a European war would naturally prove one of the first commodities to suffer in this country was a foregone conclusion amongst those who had studied the subject at all closely, the point of greatest and immediate danger being the pit prop and pitwood supply of the mines, of which some $£ 4,400,000$ worth were imported in I9I3. Further, it was realised that a war in which Russia was involved with her near Western neighbour would, with the closure of ports, be seriously felt in this country, since we are indebted to Ruscia for some $£$ I2,800,000 sterling of timber imports annually, more than a fourth of our total imports of forest materials from the whole world.

An examination of the Board of Trade Returns for the first six months of the war (to end of January I9I5) shows that the imports and consumption under all heads of timber, etc., including wood pulp and pulp board, dropped slightly less than a third, the total values for the six months August I9I 3 to January I9I 4 being $£ 22,346,000$, as against $£$ I 5,7 I 4,000 for the first six months of the war.

Considering first pit props and pitwood, we find that the supply of this material fell considerably. The returns for the six months show that $1,051,054$ loads were utilised, as against $I, 932,823$ for the similar period in I9I3-I4, the values being $£ I, 653,366$ and $£^{2}, 585,80 I$ respectively, a decrease of nearly a million pounds sterling. Wood pulp and pulp board is another com- 
modity in which a shortage was feared. This anticipation has not, up to the present at any rate, been fulfilled, the imports even showing a slight increase for the period, though an advance in price is apparent. This satisfactory state of affairs is probably due to the fact that the chief importing countries are Norway and Sweden, the command of the sea having enabled the trade to be maintained. The supply for the six months has been 571,483 loads, as against 570,865 loads of the previous year. As has been said, the price has risen, the values being given at $£ 3,214,903$, as against $£^{2,932,745}$ for I9I3-I4.

As regards large timber- logs of fir, oak, teak, etc.there has been a considerable falling off in the supply, 289,02 I loads as against 448,896 the previous year, valued at $£ \mathrm{I}, 442,080$ and $£ 2,027,402$-a drop of over half a million. Under this head there is, as was to be expected, a big decrease from Russia, whilst Germany sends nothing and America I8,700 loads less than during the corresponding period last year. In the case of converted wood materials imported under the heads of sawn or split, planed or dressed timber, the returns show a decrease of well over a million loads $(2,444,027$ as compared with $3,794,377$ loads in I9I3-I4), the values being $£ 8,313,558$ as compared with $£$ II,965,89I - a decrease of over three and a half million pounds sterling. Lastly, for a miscellaneous group, comprising staves, mahogany, and unenumerated items, the values for the war period are given as $£ x, 089,802$, as compared with $£ 2,833,843$ for the corresponding months the previous year-a drop of about one and three-quarter million pounds sterling. 


\section{I84 EFFECT OF WAR ON TIMBER SUPPLIES}

The total decrease in the values of timber imports for the first six months of the war amounted to $£ 6,632,000$.

The totals under the five groups into which the timber and other forest imports may be divided are shown below in pounds sterling:

\begin{tabular}{|c|c|c|c|}
\hline Group. & Classiflcation. & $\begin{array}{l}\text { Previous Year } \\
\text { Aug. I913 to } \\
\text { Jan. 1914. }\end{array}$ & $\begin{array}{l}\text { War Period } \\
\text { Aug. 1914 to } \\
\text { Jan. 1915. }\end{array}$ \\
\hline \multirow{5}{*}{$\begin{array}{l}\text { I. } \\
\text { II. } \\
\text { III } \\
\text { IV. } \\
\text { V. }\end{array}$} & \multirow{5}{*}{$\begin{array}{l}\text { Hewn Timber-fir, oak, teak, } \\
\text { etc. } \\
\text { Pit props and pitwood } \\
\text { Sawn or split, planed or dressed } \\
\text { timber } \\
\text { Miscellaneous-staves, maho- } \\
\text { gany, etc. } \\
\text { Wood pulp and pulp board }\end{array}$} & $\begin{array}{c}\frac{t}{t} \\
2,027,402 \\
2,585,801\end{array}$ & $\begin{array}{c}\frac{f}{1} \\
1,442,080 \\
1,653,366\end{array}$ \\
\hline & & & \\
\hline & & $\mathrm{II}, 965,89 \mathrm{I}$ & $8,313,55^{8}$ \\
\hline & & $\begin{array}{l}2,833,843 \\
2,932,745\end{array}$ & $\begin{array}{l}1,089,802 \\
3,21_{4}, 903\end{array}$ \\
\hline & & $22,345,682$ & I $5,713,709$ \\
\hline & $\begin{array}{c}\text { Deficit for six months war } \\
\text { period }\end{array}$ & & $6,631,973$ \\
\hline
\end{tabular}

Now, the total value of the imports of these materials for the year I9I3 amounted to a sum of $£ 42,725,000$, roughly divided among the above groups as follows:

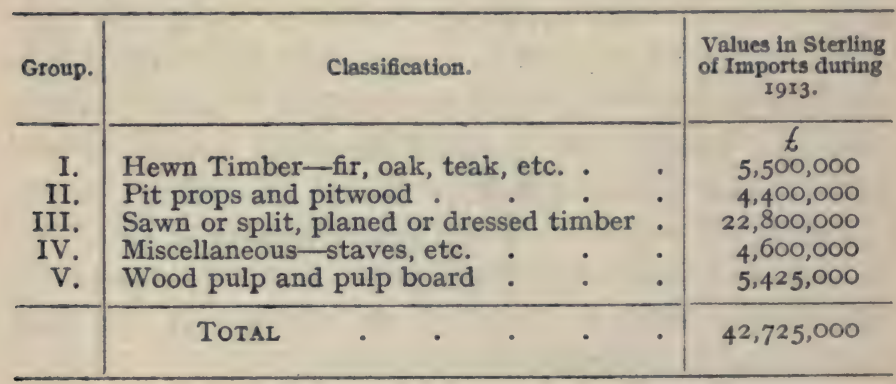


The totals in Groups I. and IV. are not quite correct for these groups, since in the Annual Statement of the Board of Trade the items are grouped differently, mahogany being included under I. For our purpose the above lump totals are, however, sufficiently accurate. A comparison of the above figures with those given in the table analyses for the six months August I9I3 to January I9I4 and August I9I4 to January IgI 5 shows :

(I) That the totals of imports for the period comprising the six months August I9I3 to January I9I4 are slightly higher in value than those for the other six months of the twelve-i.e. $£ 22,345,682$ as against £20,379,3I8.

(2) The decrease for the first six months of the war amounts to practically a little under a third of the total imports of the year, supposing the decrease were to be maintained during the following six months.

(3) That importing countries, unaffected directly by the war-i.e. non-belligerent countries-have not yet taken full advantage of the favourable market conditions existing in this country to increase their supplies to any very large extent, with the exception perhaps of Norway and Sweden. This apparent inaction in the face of so favourable an opportunity is probably due, in part at least, to the shortage in freight vessels already commented upon.

A great variety of different industries and trades in this country are dependent upon the various classes of 


\section{I86 EFFECT OF WAR ON TIMBER SUPPLIES}

timber and other forest imports, such as, e.g., pulp mills, saw mills, furniture factories, brush factories, bobbin manufacturers, etc., and builders, carpenters and joiners, etc. It will therefore be of some interest and perhaps of value to analyse group by group and month by month the imports of the various materials, indicating where possible the countries from which the imports have been obtained and the deficits in the amounts received. Such an analysis will enable us to form an opinion as to the directions in which the pinch is already being felt, by a comparison of the fall of imports with an increase in price; at the same time it will be possible to ascertain the directions in which increases in imports over those for the same months of the previous year have taken place. In the previous article it was pointed out that Norway and Sweden, as also the countries across the Atlantic-Newfoundland, Canada, etc. - would be likely to take advantage of a rise in prices and a dearth of material in this country. Such a state of affairs has to some small extent already made itself felt, transport facilities in the way of available ships having probably been the chief deterrent up to date. There is still, therefore, scope for the exploitation of available home supplies, which, owing to their inferior quality and heavy railway freights in this country (now somewhat lowered for some classes of produce), could not previously compete satisfactorily with the imported material. Taking our first group, Hewn Timber (fir, oak, teak, etc.), the table on p. I 88 shows month by month the quantities and values received during the periods August I9r3 to January I9I4 and the war period August I9I4 to 
January I9I5. Some points of interest can be derived from the figures there given.

In the first instance, each month of the war showed a steady drop in the imports as compared with those of the same month during the previous year; and all the countries from which the imports came participated more or less in this decrease. German imports disappear at once, as also, though not shown separately, does Austrian oak. Russian imports drop from 222,000 loads valued at $£ 522,000$ to 99,000 loads at $£ 203,000$, the latter figure being fully as much perhaps as one could have expected from her under the circumstances. From Sweden the imports show a slight decrease of 2,600 loads, whilst the price rises by $£ 2,000$ odd. Norway exhibits consistently rising imports for the six-month period, the total being nearly double that of the previous year, valued at $£ 50,700$ (as against $£ 25,200)$ - a most satisfactory state of affairs. From the United States, as also Canada, the imports fluctuate, some months of the war showing a rise, notably August and November for America, and August, September, and October for Canada. America has a total decrease of about $£ I 80,000$ in values for the war period, whilst Canada, with a slight total increase of imports, has a corresponding slight increase in values. From British India the chief export in timber is teak, and here the market would appear to be recovering itself by January I9I5, this latter month (with the exception of September) being the only one to show an increase of this material over that of I9I4. The totals exhibit a small decrease $(15,000$ loads to 13,000 , valued at $£ 280,000$ and $£ 249,000)$, there being an advance in 


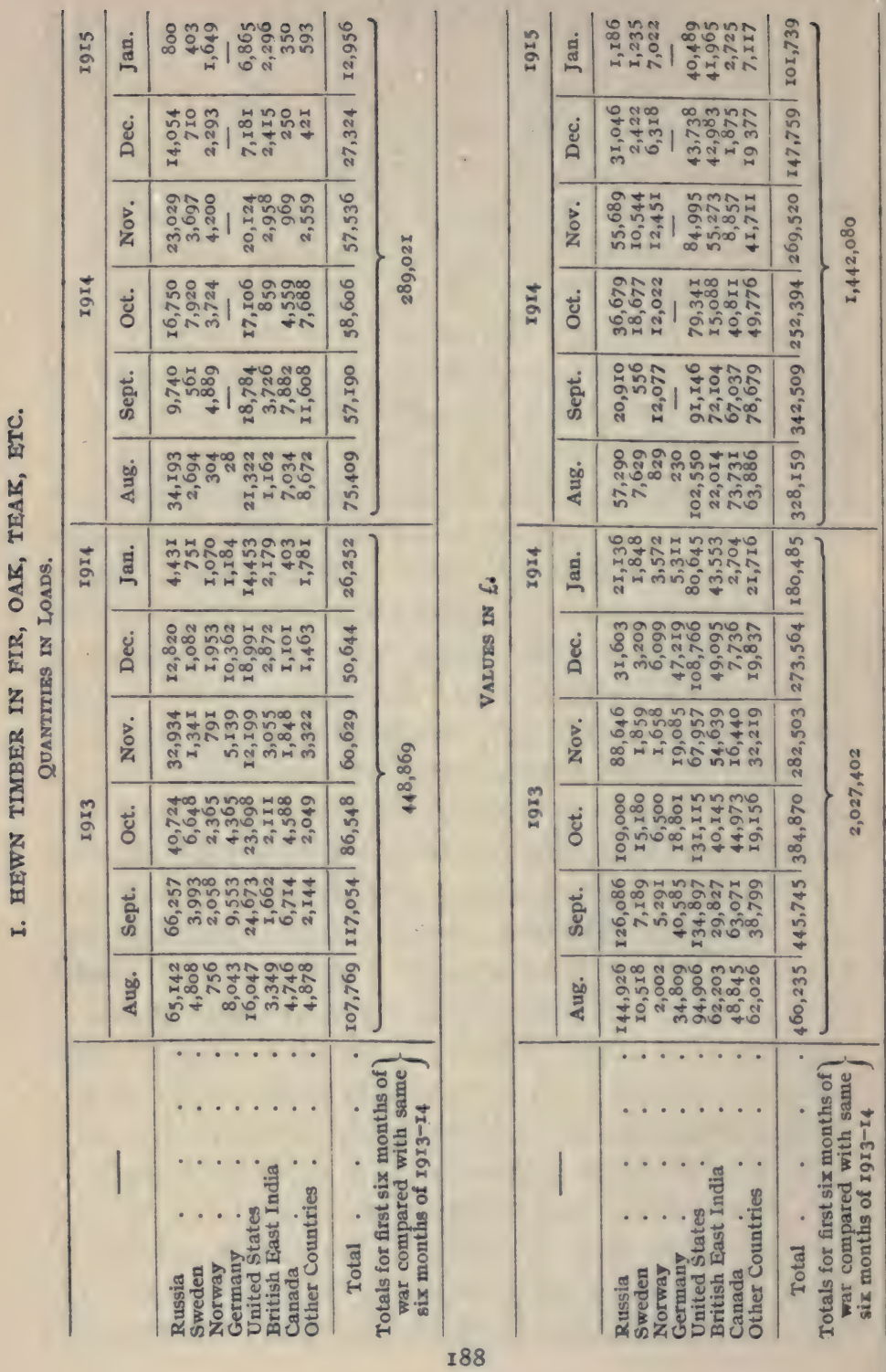


price per load from $£$ I 8.6 to $£ I 9$. I. From "Other Countries" in this group there was a considerable increase during the first three months of the war, followed by a drop in each of the subsequent months. The quantities for the war period more than doubledI5,000 to 33,000 loads, valued respectively at $£$ I 94,000 and $£_{2} 6 \mathrm{I}, 000$, a most satisfactory item to the credit of the account.

Group II., Pit Props and Pitwood, has been already dealt with, each month showing a decrease, as is indicated by the following figures for the periods :

II. PIT PROPS AND PITWOOD.

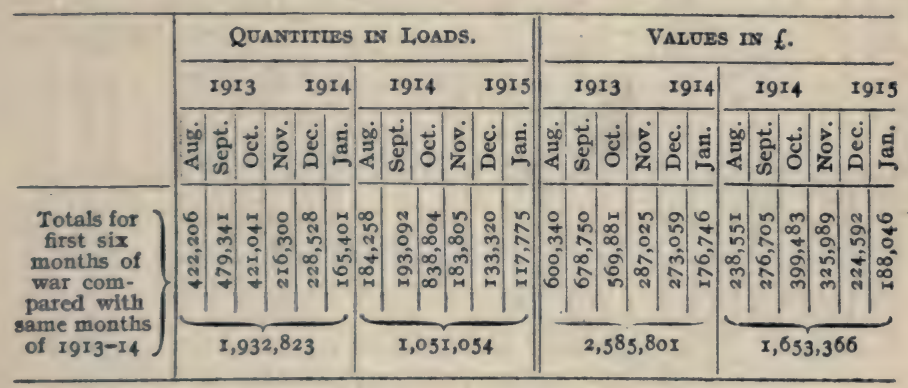

There was a slight increase in price per load (from $£^{\prime} \cdot 36$ to $\left.£^{\circ} 54\right)$. In view of the fact that our chief supplies of pit materials come from Russia, who sent us $f_{2}, 400,000$ worth during the year I9I 3 , and from France ( $£ 830,000$ in I9I3), it is to the good that supplies have been as well maintained as the above figures indicate.

The third group consists of sawn or split, planed or dressed timber, including sleepers, which the Board of 


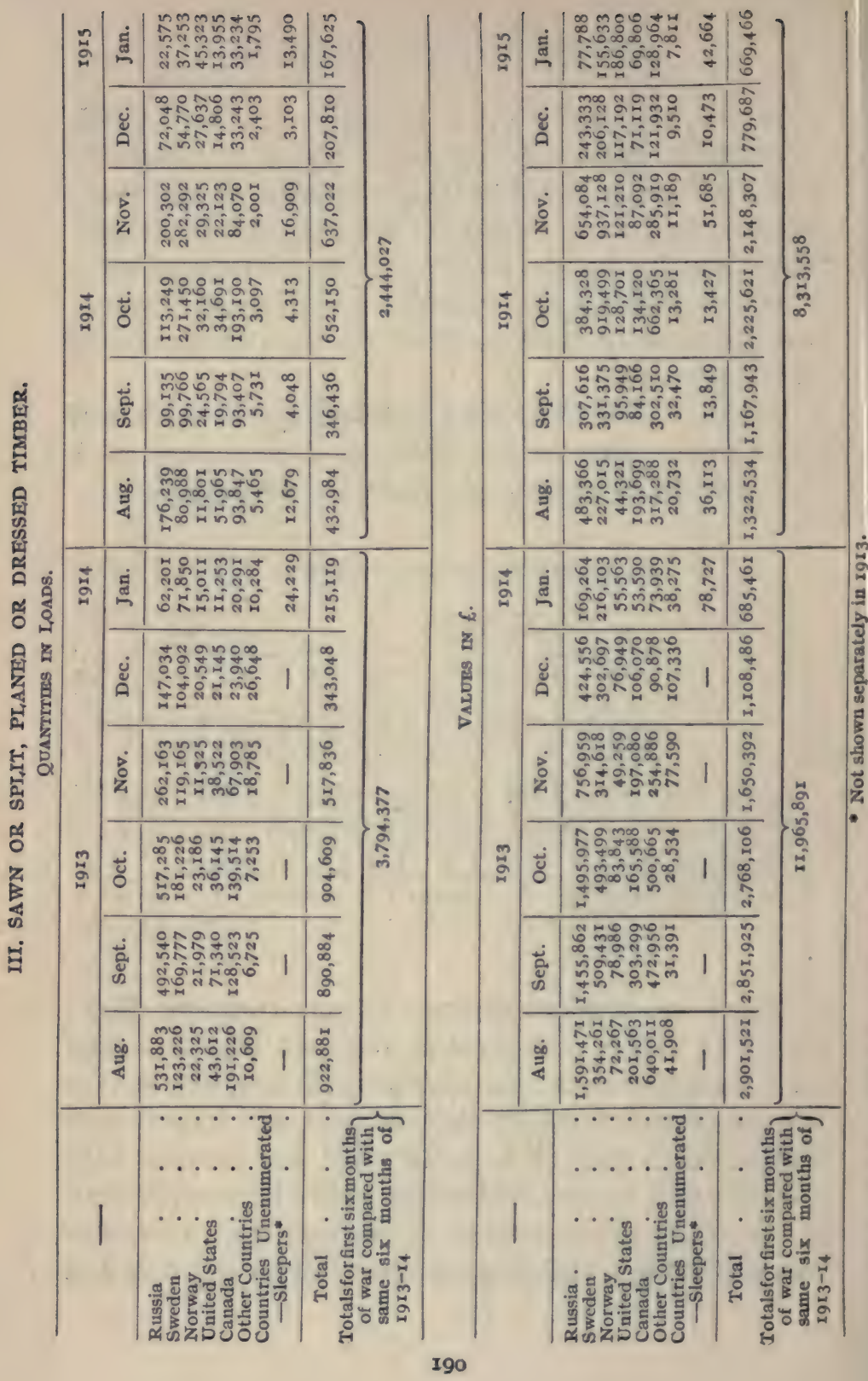


Trade now show separately in its returns. With the omission of India and Germany, the countries from which the imports come are primarily the same as those of Group I. The table on p. Igo shows the variations in the imports for the two periods under review. Under this group we have a very heavy decrease in Russian imports, from 2,013,000 loads to 683,000 , valued at $£ 5,894,000$ and $£ 2$, I 50,000 respectively, a decrease of value of approximately three and three-quarter million pounds. Sweden exhibits a better position, there being a decided recovery and increase in imports during September and October of I9I4, resulting in a balance on the right side for the six months, the figures being 826,000 loads (as compared with 769,000 for I9I3-I4), valued at $£ 2,776,000$ (compared with $£ 2$, I90,000), an increase of half a million. Norway also comes out with a satisfactory rise on totals for the six months of the war, whilst at the same time showing a consistent increase for each month over the imports for the similar months of the previous year. The totals come to I7I,000 loads (compared with II 4,000 ), valued at $£ 694,000$ (against $£ 4$ I 7,000$)$. Similar results cannot unfortunately be recorded for the United States of America, there being a decrease on imports for every month except August I9I4, the total values being $£ 640,000$ for the war period, as against $£ \mathrm{I}, 028,000$ for the previous year. Canada, on the other hand, after a considerable drop in imports during August and September of I9I4, showed a consistent increase for the remaining four months of the war period. The totals for the whole period, however, did not reach those of the previous 


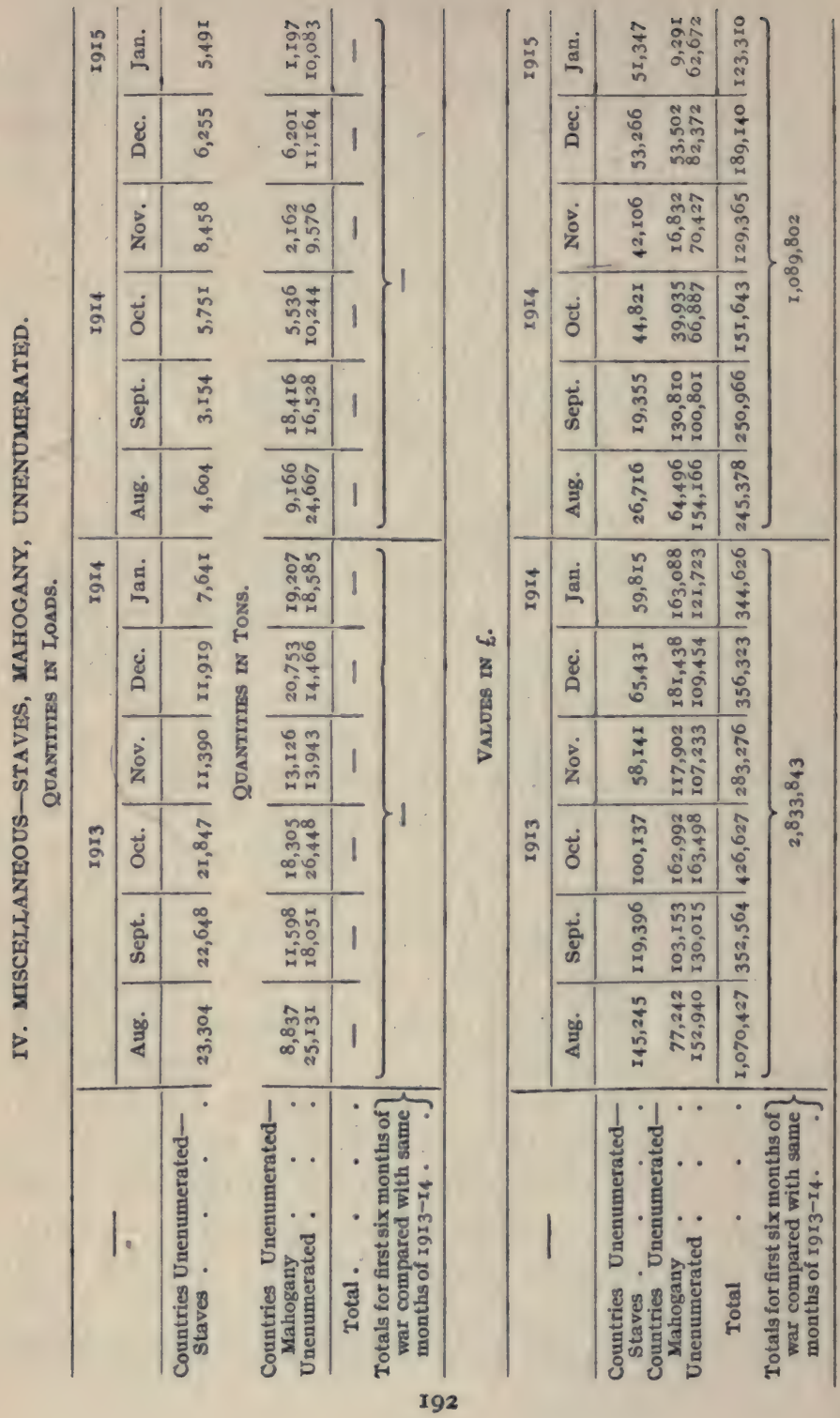


year- 530,000 loads to 572,000 , valued respectively at $£^{1}, 819,000$ and $£ 2,034,000$. There was also a small decrease of about $£ 62,000$ sterling under the head of "Unenumerated Countries" for this group.

Group IV. consists of miscellaneous products, including mahogany, staves, etc. The details of the imports for the six months' period are given on p. I92. The imports of staves, as shown by the table, have dropped to exactly one-third during the past six months $-33,000$ to 99,000 loads, valued at $£ 237,000$ and $£ 547,000$, the price having risen from $£ 55$ per load to $£ 7^{\circ}$ I per load. As was to be expected, the imports of mahogany decreased from 92,000 tons to 42,000 tons, valued at $£ 805,000$ and $£ 315,000$. A point of interest about these figures is that the price of this fine timber dropped during the period from $£ 8.7$ per ton to $£ 7.5$ per ton. The "Unenumerated" materials in this group also show a decrease of nearly a quarter of a million pounds sterling.

Our last group, Group V., consists of wood pulp and mill-board and wood-pulp board. It is a group possessing peculiar interest at this juncture. Setting aside the question of the daily Press, which is so dependent upon this material, we should all of us find it difficult to get on without the cheaper forms of paper, even in our domestic life. Perhaps the most significant feature of the imports of this product of wood lies in the fact that whilst the imports during the war period actually rose to a slight extent, the price has also risen as compared with the same period during the previous year. This increase must presumably be attributed to the rise in shipping freights. The price rose from 


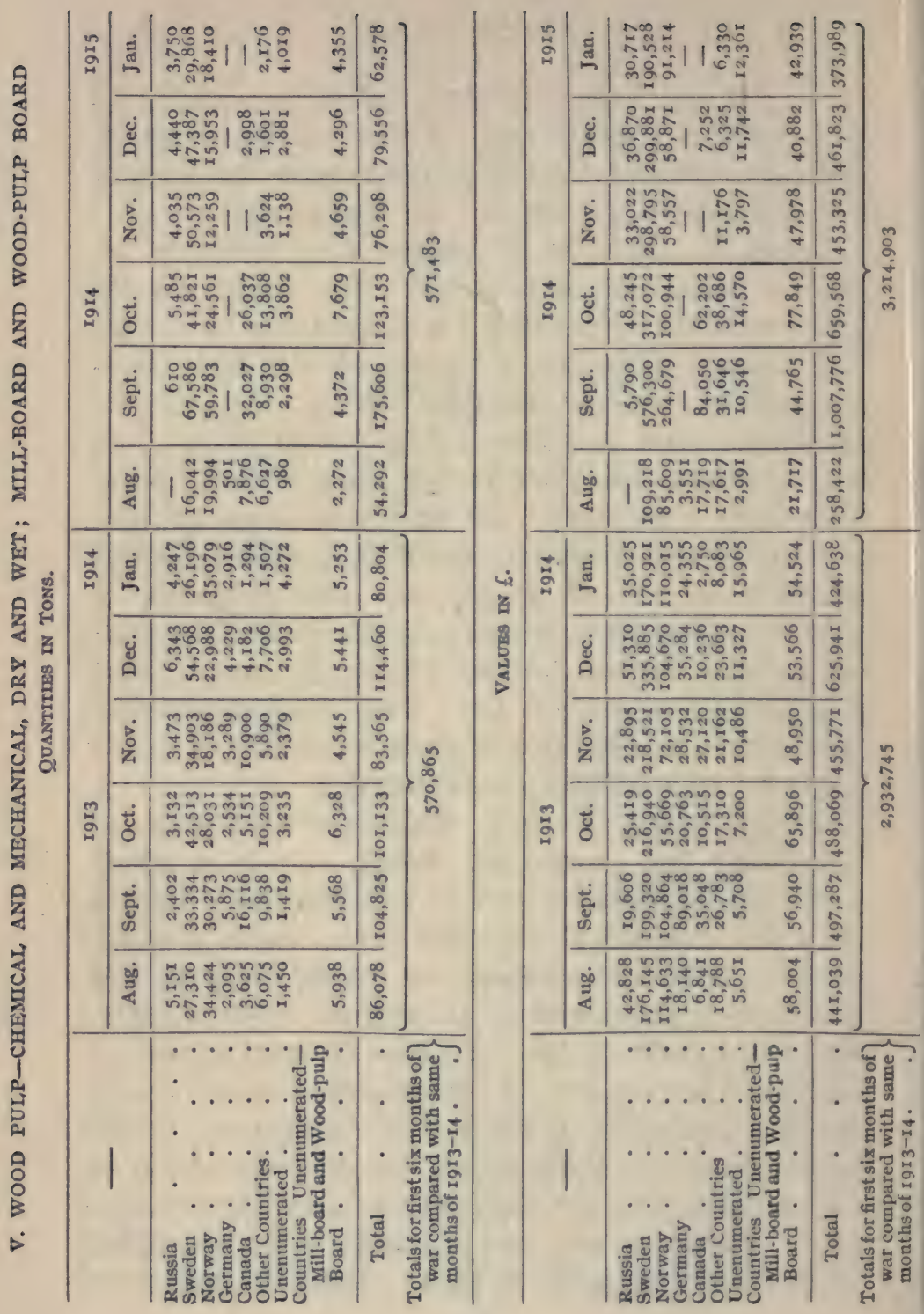


$£ 5^{\circ} \mathrm{I}$ per ton to $£ 5^{\circ} 6$ per ton. The detailed table of Group V. is given on p. I94. Russia exhibits a curious fluctuation in her imports under this group. An almost total absence of cargoes during the first two months of the war is succeeded by a considerable increase over the previous year's totals for October and November, followed by a decrease in December and January, resulting in a total drop of $£ 42,000$ worth of imports. Sweden, in spite of some fluctuations, shows a decided increase of imports for the period from 219,000 tons to 254,000 tons, valued respectively at $£ I, 3 I 8,000$ and $£ I, 792,000$, an increase of $£^{I}$ per ton in price. Norway has also secured a rise in price for her imports of this material, although the bulk imported is some $I 7,000$ tons less than during the same months in the previous year. The increase price, as in the case of Sweden, amounts to $f I$ per ton. The German imports ceased altogether after August, when $£ 3,500$ worth was received. This meant a decrease from the previous year of 20,500 tons. In November and January of the war period Canada imported no wood pulp to this country, and in December her imports were smaller than those of the previous year. During the first three months of the war the amount of wood pulp sent to this country was much greater than for the same period the previous year, with the result that her imports of wood pulp for the six months' war period rose from $4 \mathrm{I}, 000$ tons in I9I 3 to 69,000 tons, valued at $£ 93,000$ and $£ I 7 I, 000$. The increase in price was only $£ 4$, indicating that the chief rise in prices of this commodity occurred during the second three months of the war. From "Other Countries" there 


\section{I96 EFFECT OF WAR ON TIMBER SUPPLIES}

was a slight decrease in the imports of wood pulp, the price of the material rising by $£ \cdot 2$. Under " Unenumerated " there was an increase of $I, 000$ tons in the receipts for the war period, the increase in the values amounting to $£ \mathrm{r}, 000$. Under mill-board and wood-pulp board there was a decrease of 6,000 tons, valued at $£ 62,000$, the price remaining the same for the period under review.

There are several points which stand out in strong relief from the above analyses of the imports of forest produce into this country. The first, of course, although it may not be fully realised by those who have not studied this question, is our almost entire dependence upon foreign materials. In fact, we purchase half of the total forest imports of the world. The comparatively small amounts grown in this country are quickly absorbed, and the price obtained by the grower or owner of the standing crop has in the past rarely been higher than 50 per cent. of the full value of the timber itself measured according to scientific principles. There are, it may be at once conceded, many reasons for this anomalous state of affairs-the chief being the want of continuity in supplies in any one locality and the smallness of the areas of woods and therefore of the amounts of timber available from them. It is perhaps scarcely fair upon the railway managements to expect them to maintain the necessary rolling-stock for the carriage of timber combined with sidings for loading it and to quote low rates when supplies are so erratic as at present. 
Secondly, it may be held that as long as we are supreme at sea there is no danger of our supplies running short in peace time. But is this a safe inference? We imported, e.g., in I9I3 nearly fifteen million pounds sterling worth of forest produce from Russia. Russia with Finland has extensive tracts of forest. The forests of Siberia have often been extolled as inexhaustible. This is perhaps not quite the truth, but, as has been shown, they are extremely valuable. The question is how long can we rely upon a continuous unchecked export of raw forest materials from Russia or from any other country. It must be borne in mind that, as with other semi-developed countries, Russia's population and industries are increasing and have made rapid strides latterly. Also, not so many years ago a Russian Finance Minister painted quite a different picture of the state of the forests in parts of Siberia from the one so commonly accepted. It was in connection with the settlement of immigrants in the country along the Siberian Railway. He pointed out that it would be necessary to give special attention to the forests of those parts, the actual condition of which was, owing to wanton destruction by the inhabitants by fire and axe, by no means so rosy as was imagined. He foreshadowed protection and State organisation of these areas. This work has since been commenced and about a fourth of this gigantic area of forests has been explored. As indicated in Article $\mathrm{X}$, the result of this investigation so far has shown them to be even more valuable than was anticipated. As regards the other countries Norway for a time, if not at present, was overcutting 


\section{I98 EFFECT OF WAR ON TIMBER SUPPLIES}

her forests-i.e. trenching upon her forest capital. Sweden was probably working up to her full possibility in this respect. The controversy over Canadian wood pulp exports with America and the preferential tariff question will still be fresh in the minds of many. Instances could be multiplied. Countries which, up to recently, have been self-contained as regards forestry products have now commenced to import and therefore to compete with us in the open market.

Another important problem with which we are faced is the effect of the war on the Continental forests in the belligerent States. Immense destruction of tree growth must be taking place in the fighting areas in many parts of the world, and more especially in Europe, whilst the consumption of wood must certainly be enhanced by the enormous masses of men now congregated together. We read of the Germans cutting down whole tracts of forest in the Allies' country they are occupying and transporting the material into their own country. The heavy howitzer shells are reported to sweep through a forest and lay the trees low as if a heavy storm had passed over the area. We have heard that even the roadside avenue trees are being destroyed wholesale, owing to the habit of picketing the horses to them. A competent forestry observer now at the Front wrote me as follows the other day : "It will take more than a hundred years to repair the damage done out here. All the trees (avenue) have been girdled by the horses to about ro feet up the stem. You see, horses are tied up under trees to prevent aeroplanes seeing them, and the usual way is 
to run a rope down a line of trees 3 feet or so up, and then tie up the animals by short head-ropes to this. Then they get at the trees and eat the bark and soft bast off. It is rather a shame, but ' à la guerre comme à la guerre." " It would seem highly probable that one of the after-results of the war will be greater competition and consequent higher prices for forest materials, and this country will be the first to feel the new condition.

Two questions would appear to confront us :

(I) Are we making full use of the opportunity which the shortage in timber supplies is affording us?

(2) Are we seriously considering the forestry problem in the new aspect in which the war presents it ?

(I) The Opportunity.-Much is being done by the Boards of Agriculture, both English and Scottish, in the direction of drawing the attention of proprietors of woods to the possibilities presented by this unique opportunity both for clearing out woods of poor development or which have suffered irretrievably from wind or snow damage; and, secondly, in adequately thinning promising young woods and selling the material as pitwood. Some proprietors realised the position at once. The question now is, Is there not some danger of available supplies being held up too long in anticipation of a still further rise in price? The opportunity is without parallel. It will be a pity to miss it. We have heard already of mines introducing iron props. These are more expensive, but, provided they can be recovered for further use, they can be made, it is thought, to pay. And by offering an extra intucement by way of pay the men are being per- 
suaded to recover them. Once the initial difficulty of introduction and recovery of these props is surmounted the managers are unlikely to go back to the wood prop, and the market for this article will be proportionately lessened at a juncture when, with the advance in British forestry, it is most important that it should be maintained. An experienced colliery proprietor said to me the other day: "The shifts we were put to after the outbreak of war to keep things going resulted in all sorts of expedients being devised, and some of these may have come to stay." The iron pit prop, for instance!

(2) The Forestry Problem.-Is it not time that a decision should be arrived at as to the percentage of the available plantable land in the country which should be maintained under woods in the interests of the community as a whole? There are many keen planting proprietors in the country. It is known-the various Forestry Commissions, appointed at intervals by the Government of the day, have dealt fully with the subject-that there are several million acres of plantable land which could be made to produce a proportion of the materials now imported. Incidentally the woods would also give rise to flourishing industries, such as pulp mills, furniture and toy factories, and the thousand and one manufactured articles which we now import, affording employment to a considerable population.

The blue-books of the above-mentioned Forestry Commissions have pointed out that town labour was useless for planting and general forestry work, as the townsman could not handle a spade or stand the hard 
work and climatic conditions entailed by forestry operations. This plea was true at the time. It is a question now, however, whether large planting schemes, if well thought out and prepared beforehand by a central organisation, could not be put into force at the conclusion of the war. Every soldier now has to learn to handle the spade and pick in trench work; and large numbers of young men who will have been hardened to exposure will at the same time have been imbued with a liking for outdoor life. At least, it seems probable that after the war they will be rather unsettled for a sedentary life in the cities. Many will emigrate unless they can find congenial occupation in this country. Numbers might be induced to take to forest work, and planting on a large scale could be undertaken.

A unique opportunity lies within our grasp. Is it going to be let slip? 


\section{XIV}

TIMBER IMPORTS AND EXPORTS IN I9I5

THE first year and a half of the Great War has brought into prominence a number of economic factors and questions, many of them by no means flattering either to our vanity or organising powers as a nation. We have discovered our entire dependence on our enemy Germany for many of our everyday requirements, one might almost write necessities-dyes, medicines, even such an important fighting material as acetone, all were made in Germany. For one economic essential, however, we were not dependent upon Germany. Our timber and other forestry materials did not come either from Germany or Austria, with the exception of comparatively small quantities. And yet, as has been already shown in these articles, we were practically entirely dependent upon imports for these materials. By the end of the first six months of the war we had realised, to some extent, our difficulties in this respect, as the preceding article has indicated. But we were still far from a full realisation of what was in front of us. True, prices had already gone up, but to nothing like the figure they were to reach by the end of another year. Our true position in this timber matter does not appear to have been fully grasped by the country 
till well over a year of the war had elapsed. The Home Timber Committee was not appointed till December I915. We had by then realised that the shortage of freight ships combined with the activities of German submarines had brought about a timber crisis-the beginnings of a timber famine. To meet the immediate needs of the moment-the urgent requirements of the War Office and Admiralty - we had to turn to such home woods as existed and make use of the material, poor in quality though much of it was, which they could furnish.

A comparison of the imports of timber materials, and prices paid for them, during I9I5 with those of I9I3 (the last full year before the war) is of some importance in this connection, for it exhibits both the falling off in supplies and the great increase in prices. In some cases-to wit pitwood-the extraordinary and serious position is disclosed of a larger sum being paid in I9I5 for a smaller amount of material ( $£ 4,700,000$ for $2,100,000$ loads) than was paid in 1913 for a larger amount of material ( $£ 4,400,000$ for $3,400,000$ loads). Had the sum of money thrown away in this manner during I9I5 been spent on afforestation twenty-five to thirty years ago we could have hoped to have had much of this material standing in woods in this country at the outbreak of the war. Surely this one instance alone should prove sufficient to awaken the nation to the very great economic importance of the afforestation question.

If we take the six groups into which forestry materials are classified in the Board of Trade Returns we obtain the following comparison of amounts 
imported and prices realised during 1913 and I9I5 respectively ${ }^{1}$ :

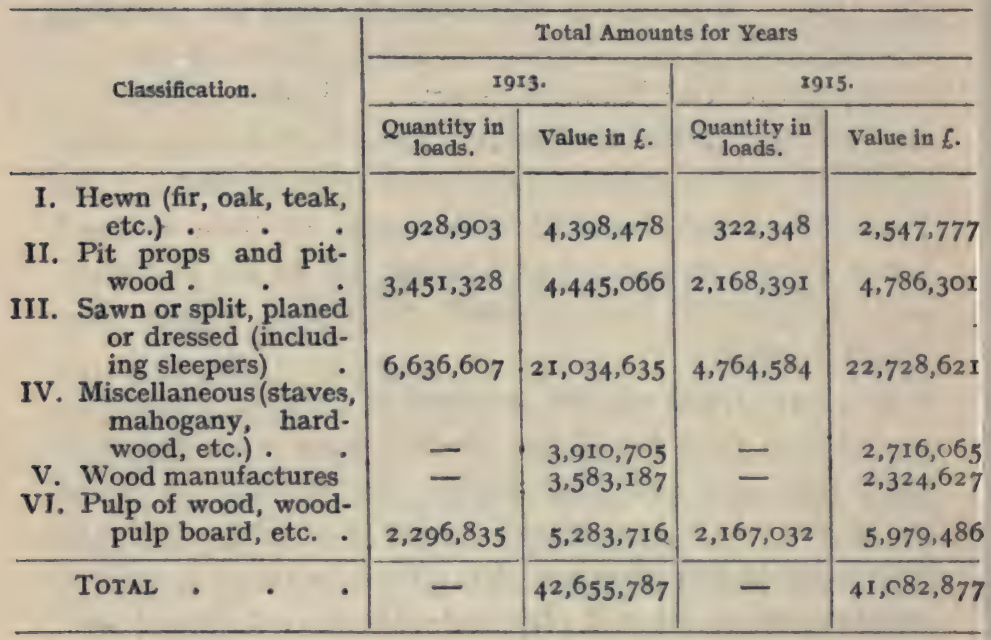

During I9I5 therefore we paid about one and a half million pounds sterling less than in I9I 3 for our forestry imports, but we received nothing like the same amount of materials for this $£ 4 \mathrm{I}, 000,000$-roughly speaking only about three-fifths; nor are we likely to do so in the years to come and probably never shall again. Nearly three-fourths of our imports fall in the first three groups, coniferous timbers (firs and pines) and pitwoods. Of these we imported in $1913 \mathrm{II}, 016,838$ loads valued at $£ 29,878$, I 79 , whilst in I 9 I 5 only $7,255,323$ loads were imported, for which we paid $£ 30,062,699-$ an increase of price of from $£^{\prime} 7$ to $£ 4^{\prime} \mathrm{I}$ per load.

If the above groups are analysed it is observable that

- These figures are taken from the Trade and Navigation Returns issued monthly. 
in Group I. (Hewn Timber) for about one-third of the material received in I9I5 $(322,348$ as compared with 928,903 loads) we paid a little over half the price paid in I9I3 ( $£ 2,547,777$ as compared with $£ 4,398,478)$. In Group II. (Pitwood) the prices, as already mentioned, are even more startling. For an import amounting to $I, 300,000$ loads less in IgI5 $(2, I 68,39 I$ compared with $3,45 I, 328)$ we paid $f 300,000$ more $(£ 4,786,30$ I compared with $£ 4,445,066)$. Group III. again(Sawn Materials, etc.) presents the same anomalies - for, with a decrease of $2,000,000$ loads $(4,764,584$ compared with $6,636,607$ in I913) we paid a million and $a$ half pounds sterling more $(£ 22,728,621$ compared with $£ 21,034,635$ in I9I3). Of Groups IV. (Miscellaneous) and V. (Wood Manufactures) we imported about $£ 2,500,000$ worth less in I9I5-about one and a quarter million less in each group. Group IV. merits analysing. It consists of staves, mahogany, other foreign hardwoods and veneers. It is difficult to understand why the step recently taken of prohibiting the import of these foreign hardwoods, veneers, etc., was not put in force at the end of the first six months of the war. Even then the tonnage difficulty was already being felt. Who requires mahogany and veneers in war-time? Even if a demand existed it would have been better to put an end to it. In I9I3, I4I,80I loads of mahogany valued at $£ \mathrm{I}, 225,879$; in I9I $4, I_{43,432}$ loads valued at $£ \mathrm{I}, \mathrm{I} 37,563$; and in I9I5, 48,284 loads valued at $£ 385,635$ were imported. For the same three years hardwoods and veneers, etc., were imported as follows : 249,4II loads@ @I,684,778 ; 226,5I3@£I,508,795; and I9I,I54@£I,6I3,042- 


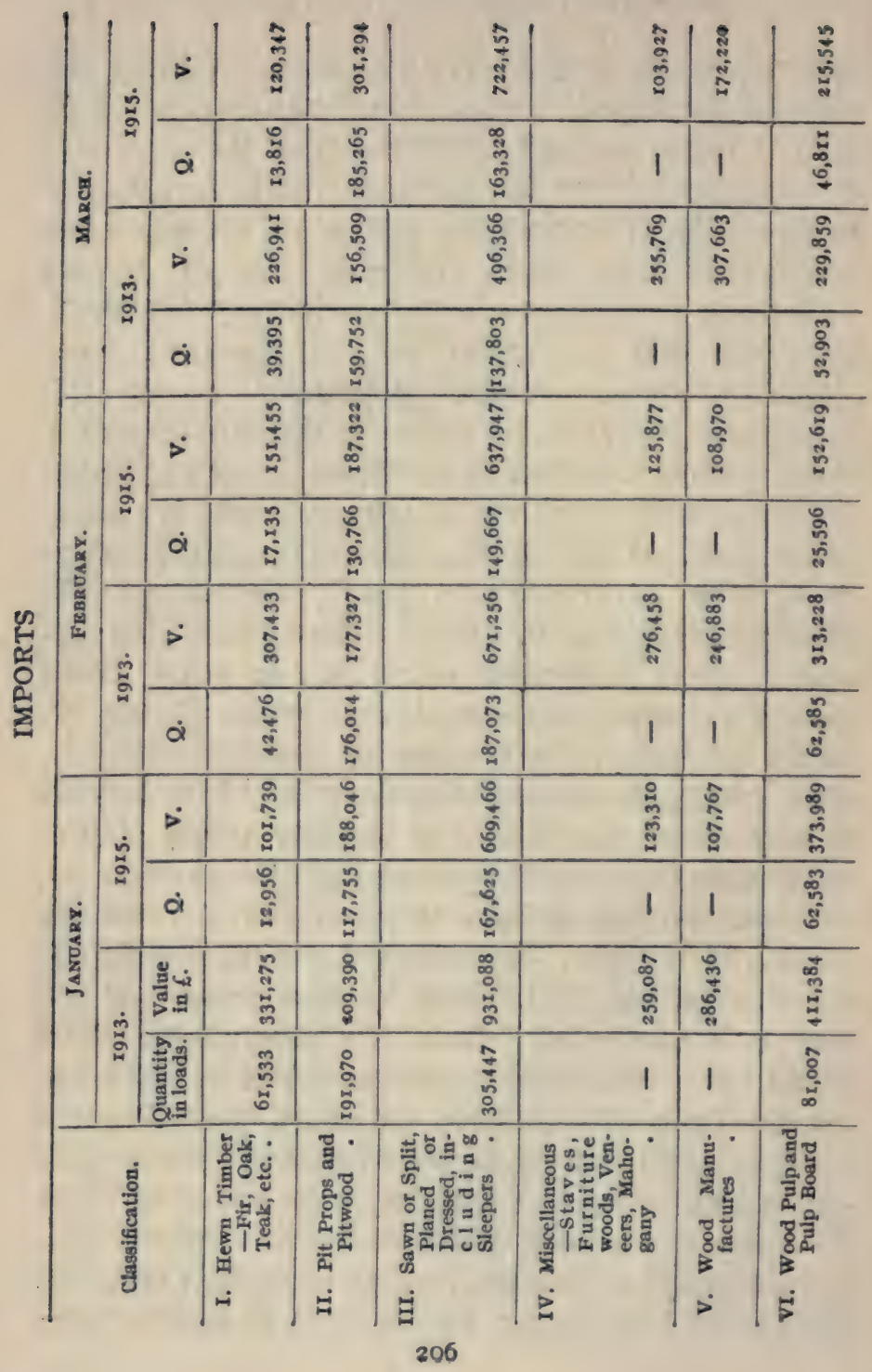




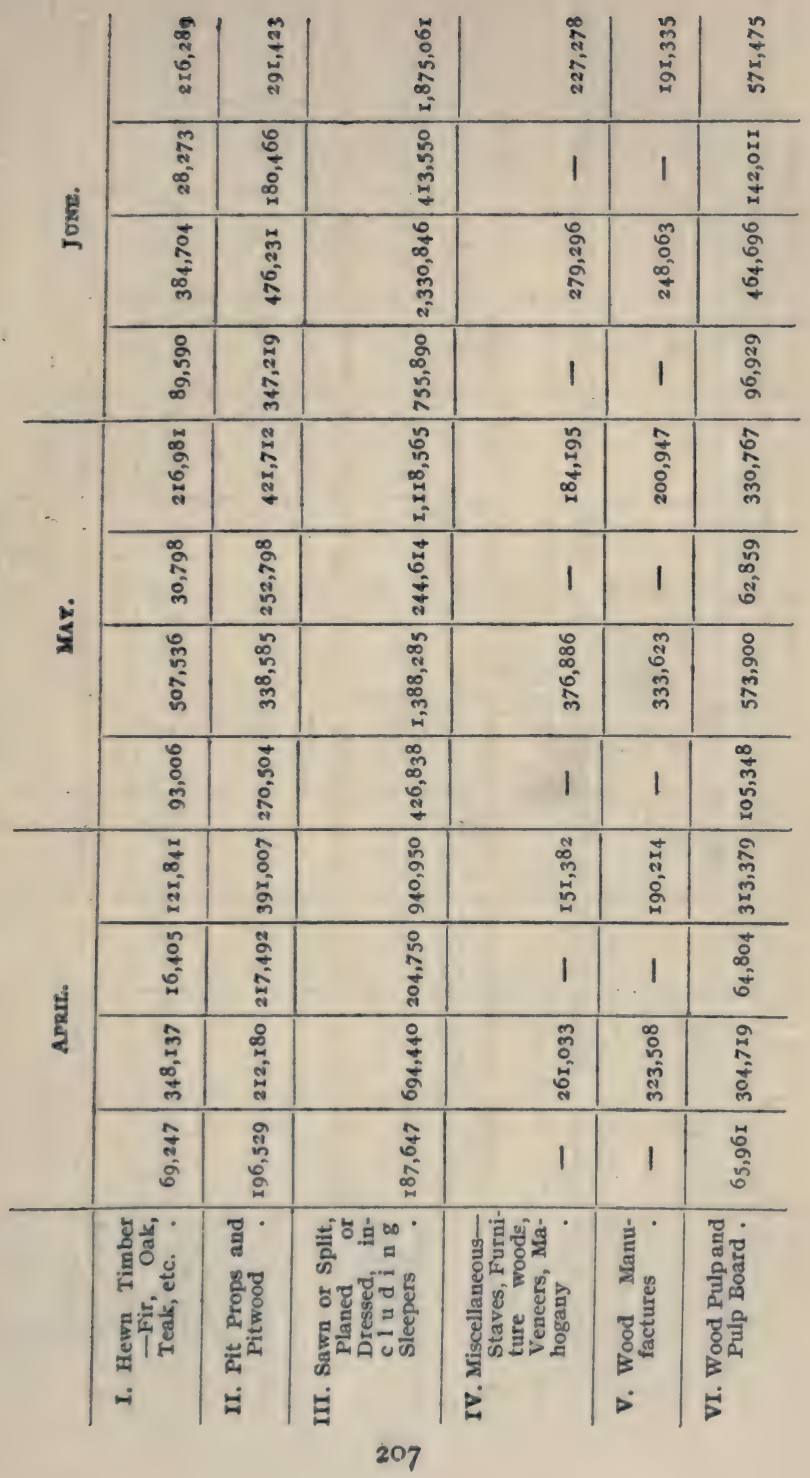




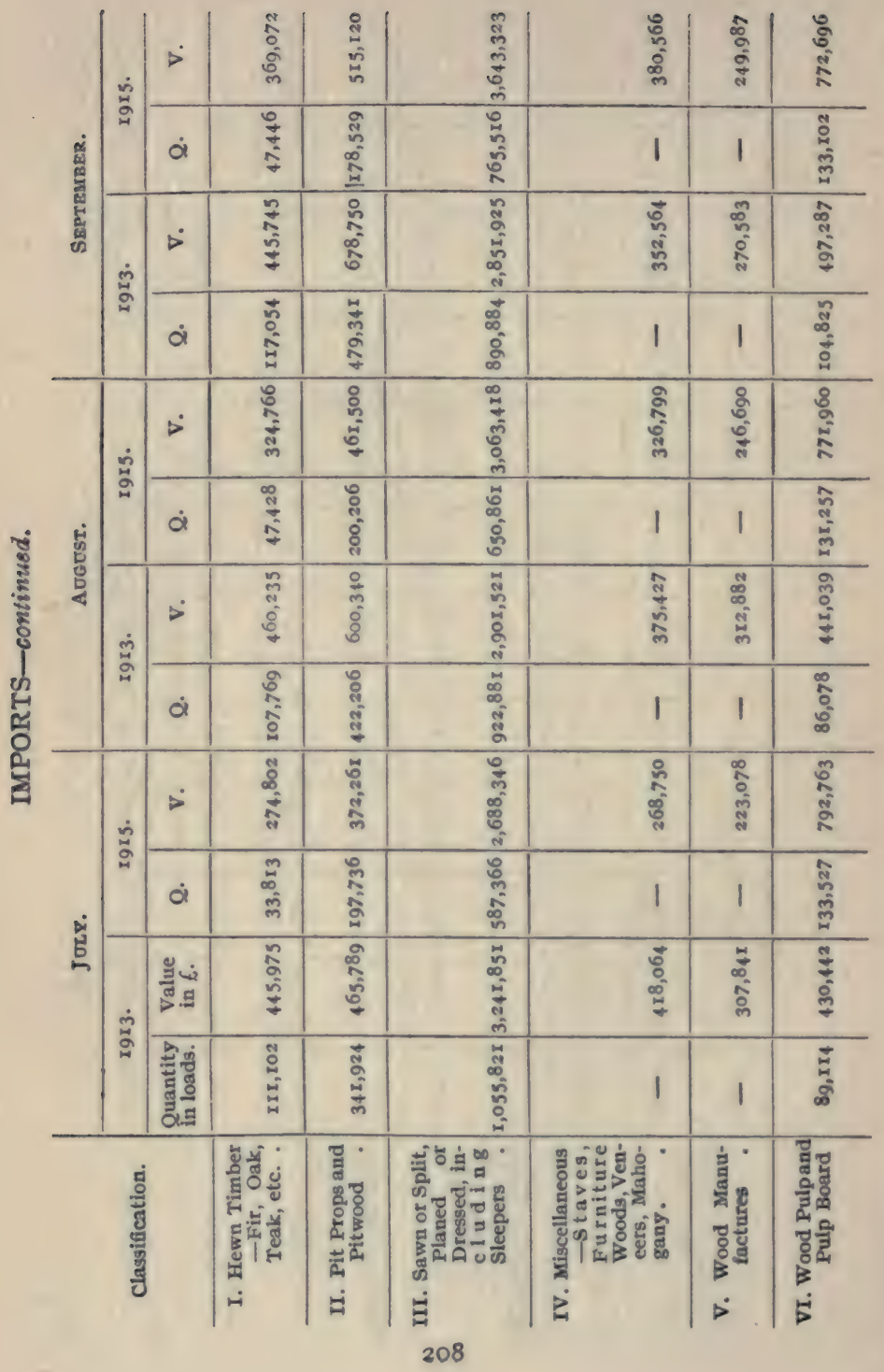




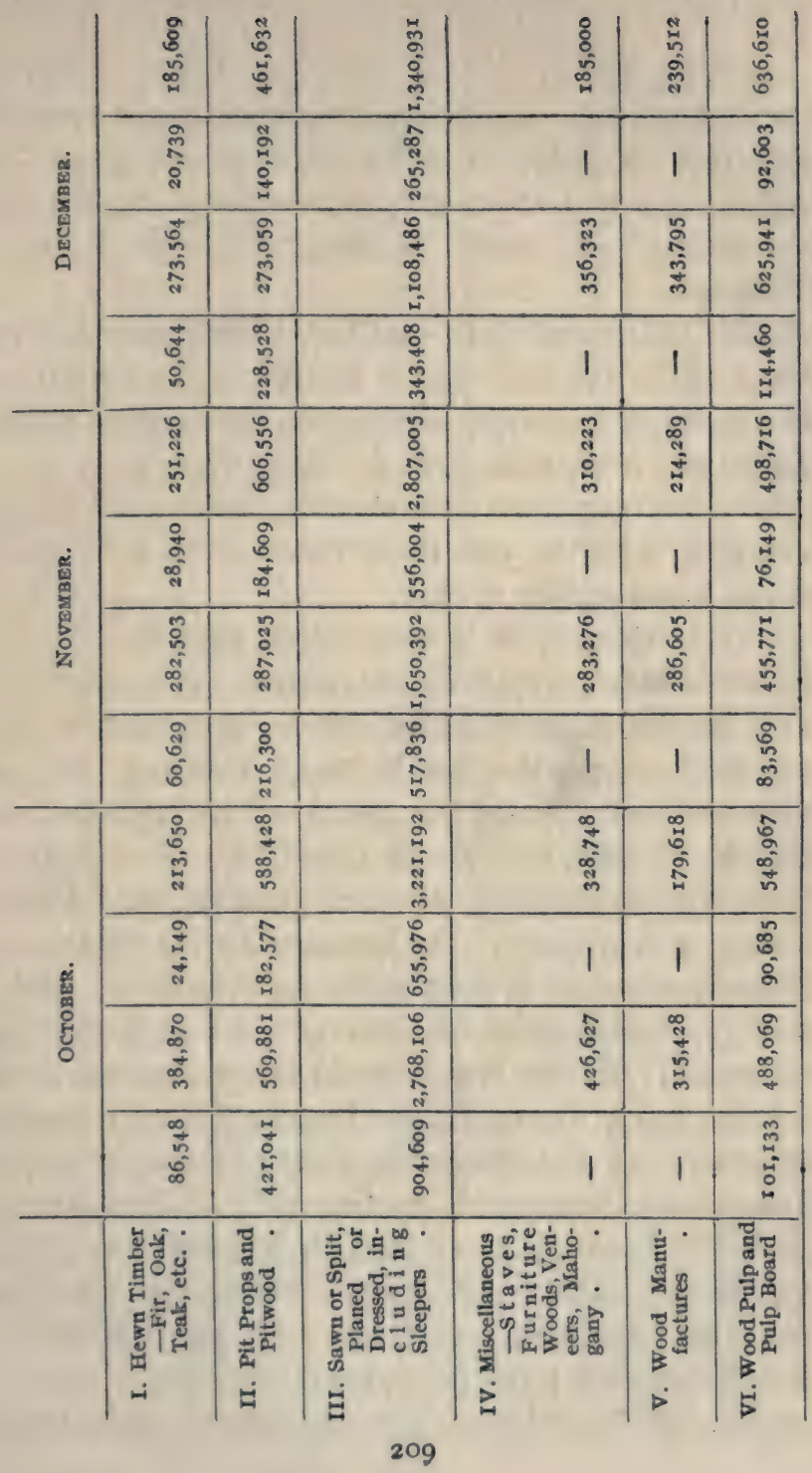


a rise in price of $£^{6} 7$ to $£^{\circ} 4$ per load. With the essentials for war operations becoming more and more difficult to supply we still continued to import mahogany, veneers and other unnecessary materials of this nature! It would be ludicrous were it not so disastrous.

Lastly in Group VI. (Wood Pulp) the imports in I9I 5 were a little less than in I9I3 $(2,167,032$ as compared with $2,296,835$ loads), whilst the price rose slightly ( $£ 5,979,486$ compared with $£ 5,283,716$ ).

The table on pp. 206-9 shows the amounts of forestry materials imported and their values month by month for the years under review.

Under Group I. it is observable that the amounts imported month by month during I9I5 were only about one-third to a half of those imported in I9I3. As regards prices the rise between January 1915 and December I9I5 was $\AA^{\prime} \mathrm{I}$ per load (12,956 loads@ $£$ IOI,739 to 20,709 loads@ @i 85,609). In Group II. (Pitwood) the increase between January and December I9I 5 was greater. In January II 7,755 loads cost $£$ I 88,046 , whereas in December 140,192 loads cost us $£ 46 r, 632$, an increase of from $£ I^{\circ} 6$ to $£ 3^{\circ 2}$ per load. In Group III. (Sawn and Planed) there was also a rise, the price going from $£ 3^{\circ} 5$ per load in January to $£ 5$ in December (I67,625 loads@ @ £669,466 to 265,287@ $£ I, 340,93 I$ in December). In Group IV. (Miscellaneous) staves fell from $£ 9^{\circ} 4$ per load in January to $£ 5^{\circ} 9$ in December; whilst mahogany, other foreign hardwoods, and veneers rose from $£^{6} \cdot 3$ per ton to $£^{8 \cdot 6}$ per ton (II,280 tons@ @ £7I,963 to I6,22I tons @ fI 140,085 in December). The imports of wood manu- 
factures (Group V.) rose from $£ 107,767$ in January to $£ 239,512$ in December. This group includes furniture and cabinet ware, house frames and fittings, chip boxes, woodware and wood turnery. The import of some of these articles has been now prohibited, a step which might preferably have been undertaken a year ago. Lastly, Group VI. (Wood Pulp, etc.) exhibits a rise in price of from $£ 5^{\circ} 9$ per ton to $£ 6.8$ per ton in December, the amounts imported showing an increase $(62,583$ tons@ £373,989 as compared with 92,603 tons@ $£ 636,6$ ro in December).

Our exports of timber, etc., materials during the past year exhibit decreases as compared with I9I3. They consisted of wood and timber (rough hewn, sawn, planed) and wood manufactures, including furniture. In the first group there is a drop on the year from 47,363 loads@ £340,745 in I9r3 to 28,260 loads@ $£$ I98,322 for I9I5. In Group II. the price realised for wood manufactures fell from $£ 2,04 \mathrm{I}, 640$ in I9I3 to $£ \mathrm{I}, 04 \mathrm{I}, 755$, a decrease of exactly a million pounds sterling. These figures can only be accepted on the supposition that the export of this class of materials is now almost confined to Government war necessities, the export of all others having been stopped owing to want of tonnage. If this explanation is incorrect it would appear that Government timber exports, sleepers, posts for wire entanglements, etc., are not shown in the Board of Trade Returns. That enormous quantities of these materials are being used in the war areas we know. We are also aware that we are intimately concerned in their supply-probably to a greater extent now than during I9I5. 


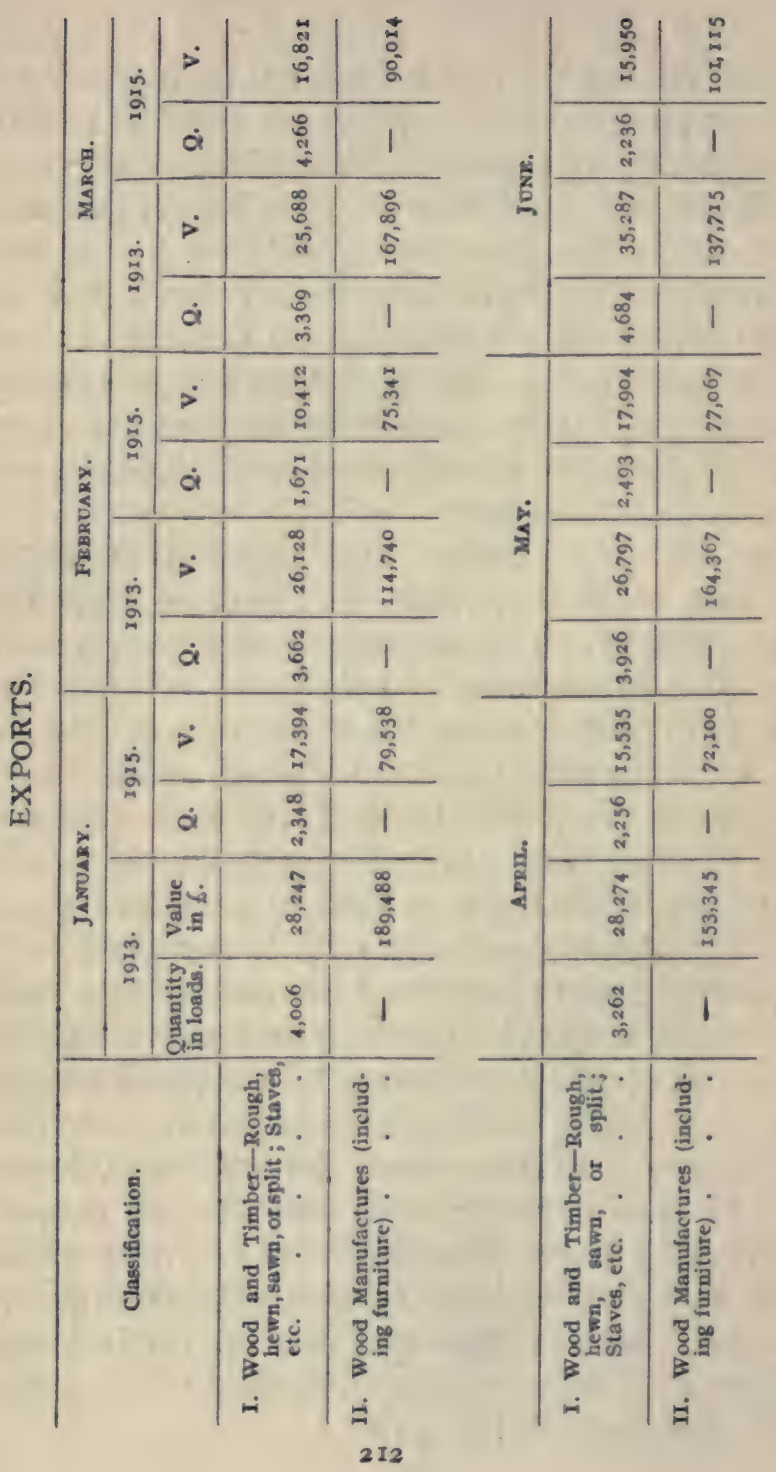




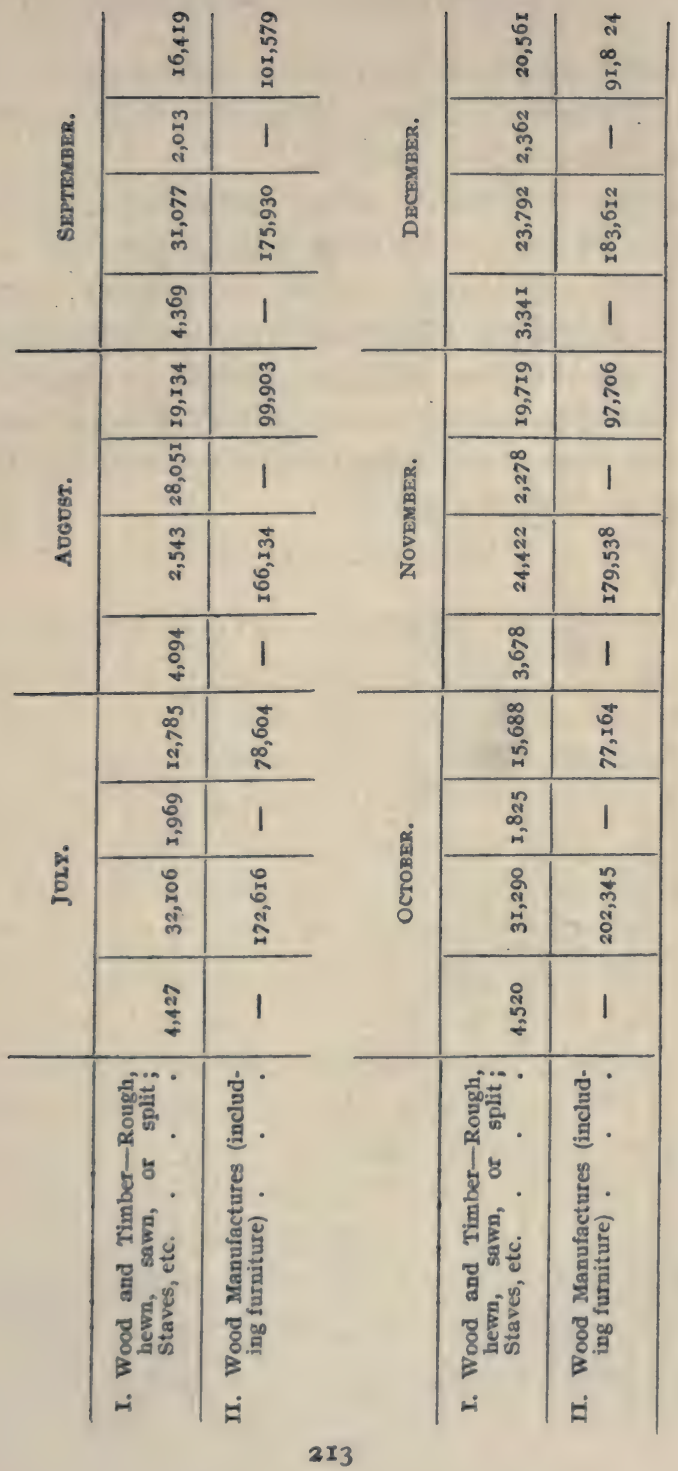




\section{I4 TIMBER IMPORTS AND EXPORTS IN 1915}

The table on pp. 2I2-I3 shows the amounts of these materials exported month by month during I $9 \mathrm{I} 3$ and I9I5 with the prices realised.

In Group I. (Timber, hewn, sawn, etc.), 2,348 loads valued at $£ \mathrm{I} 7,394$ were exported in January as compared with 2,362 loads valued at $£ 20,561$, the price rising from $£ 7^{\circ} 4$ per load to $£ 8.7$. In Group II. (Wood Manufactures) values only are shown in the Board of Trade Returns, the amounts realised for January and December I9I5 respectively being $£ 79,538$ and $£ 91,824$ -a slight increase only. 


\section{PART IV}

\section{THE EMPLOYMENT OF WOMEN IN \\ FORESTRY}

\section{XV \\ WOMEN AND FORESTRY ${ }^{1}$}

I AM very grateful to the Edinburgh Franchise Club for affording me an opportunity of placing before them some aspects of the forestry question in the country and the directions in which, as I think, women can give us very considerable assistance. Some of you may be aware that there exists, amongst other economic problems in this country, a forestry one. This problem is, or has proved in the past, somewhat complicated since it has seemed to contend with or threaten other vested interests. It will also necessitate the expenditure of a certain sum of money. And in whatever form this money may be subsequently laid out it has first to be secured. A treasury is always a difficult place to delve for gold in, and a Government Treasury often the most unproductive of all.

I do not propose to trouble you with the history of the afforestation question in this country. Whatever

1 A lecture delivered before the Edinburgh Franchise Club on February 2, 1916. 
it was it is in the past, for one thing and for another the Great War is bringing about so great a change in our economic problems that in most cases the point of view from which they were approached before the outbreak has entirely altered. To some extent this is true of the afforestation question.

And I for one believe that it is of the first importance that the women of the country should now make it their business to learn the nature of the forestry problem, to grasp the directions in which it can be made to help in the economic life of the nation, and then to use the whole strength of their influence to see that the desired ends are attained.

Women can help in forestry in more ways than by actually performing the work of foresters or forest labourers. Forestry is now becoming a vital question to us. It had a very considerable importance before the war in view of the fact that we import a very large amount of timber and other forest products. It may surprise you to learn that $£ 42,000,000$ sterling worth were imported in I9I3. And large industries depend on this amount of materials coming into the country. We could grow ourselves a considerable proportion of this material on what is at present virtually unproductive ground, that is, land bringing in as little as $2 s$. to $2 d$. per acre or less. As I have indicated, the matter was important before the war. As a result of the Great War it has become a vital necessity that this forestry business should be understood by the public at large and that it should receive at the hands of the Government the attention it demands in the interest of the nation. Women can aid in this work. 
We are not a forestry nation. For instance, how many of us have ever given a thought to where the common wooden articles of the household come from ? It would probably be a puzzle for many housewives to say where the bundle of firewood, the ordinary kindling, comes from; how it is grown; or how it gets into the form they commonly know it by! And if difficulty is experienced in furnishing a solution to this simple conundrum, the more difficult ones in connection with our timber imports, on which this enormous sum of $£ 42,000,000$ annually leaves the country, may well be looked upon as insoluble by the average woman or man.

Now though we are not a forestry nation in that we do not grow the materials we require, before the war we imported about half the total forestry imports of the world and the British timber markets ruled those of the world. All imports, mind you! What we grow in these islands was a negligible factor on the market in pre-war days. And yet we have'millions of acres of waste land-land which if planted would maintain a very considerable population on the soil, a population which previous to the war was, as we all know, emigrating in hundreds and thousands.

I may be told that woods, the maintenance of woods managed commercially, do not employ as much labour as agriculture. Granted. They do not in the actual working. But there is no idea of planting up agricultural lands. The millions of afforestable land in this country are worthless from an agricultural point of siew, and no outlay of capital could make them a paying concern agriculturally. 
But a considerable part of them can be made a paying proposition from a commercial forestry point of view, and it is now an urgent duty on the part of the Government to tackle this matter in a broad statesmanlike manner. In the interests of the nation and of our children we want these millions of acres placed under trees, in as short a space of time as possible. It will be a sound investment and the nation will no longer be at the mercy of the foreigner, as is the case atpresent.

And then remember that once you have a large area of woods in a country, factories dependent on these woods, pulp mills, furniture factories, saw mills, etc., appear and provide labour for a considerable population, and labour which lies away from the large cities; since these mills and factories are erected as conveniently close to the forests as possible. The agricultural population is also favourably affected by the presence of considerable areas of woods in their neighbourhood, for they can find employment in the woods in the winter, when most of the forest work is done, to supplement their farm wages at the other periods of the year. Further, they can occupy the long winter evenings in making toys. In all the continental forestry countries, in Germany and Russia for example, this toy-making industry is a considerable source of profit and provides welcome additional money to the field labourer. Our position in this toy-making industry has been brought sharply to the notice of us all in these days of stress. The import industry of cheap toys made in Germany and elsewhere abroad was brought to an abrupt end by the war, and the grotesque exhibitions of our capacity in this direction 
were in evidence last winter. We shall of course improve on this, have already improved on it. But so far as the toys requiring wood are concerned, and their number is legion, we have not got the wood in the country and you cannot expect to get the cheap toys made in afforested countries if you have first to import your wood to make them and pay the cost of importation.

We all know how extraordinarily critical the child is in all that pertains, I was going to say, to its welfare, but I will limit myself to one branch of its life only, its amusements. Very early in life the child commences to form its own opinions on this subject and any departures from what in its own mind it considers to be the normal state of affairs are met by criticism which we have all probably at one time or another found it extremely difficult to explain away. Many of us must, I think, have had some uncomfortable moments to face over this matter of the children's toys since the outbreak of war. It was but one of the numerous directions in which we depended entirely on the foreigner to provide our requirements. And more especially was this the case with the enormous department of the cheaper toys which after all are all that the greater number of children of this country have any acquaintance with. It is difficult to picture the amount of sorrow, small sufferings if you will; but looming very large in the childish mind, which must have been experienced by the childhood of the nation since the well-known, eagerly welcomed, and, for their price, exquisitely made foreign toys failed us with the outbreak of war. Women naturally, ever in the fore- 
front where the child's welfare and happiness are concerned, came to the rescue at a very early stage, and extraordinarily good work in this, for us an entirely new industry, has been accomplished. But in all cases where wood has been required for the purpose in view, good work was an impossibility. For one thing good seasoned material is a necessity. Such material as was available in the country was quickly absorbed for the important military and naval requirements. We have only an odd 3,000,000 acres of woods in this country, mostly kept up for sporting or ornamental purposes. What these can give has been required for national uses, pitwood for the mines, to mention a necessary article known to us all; since without it the supply of our household coal would fail us. And we all know how the price of this commodity has jumped up with the enhanced price of this pitwood and for other reasons.

To give you one instance of a toy which is dependent on wood. Take the ordinary box of bricks. I tried personally last year on more than one occasion, and others tried for me, both in Edinburgh and London, to buy a box of bricks, the ordinary wooden bricks so dear to the heart of the child ; and with which, by the way, it may be kept happily and peacefully quiet on the floor whilst one sits equally peacefully in an easy chair absorbed in paper or book. The old box of wooden bricks, beautifully made of seasoned wood, was not to be had for love or money. The one actually secured was, from the child's point of view, very short weight. The bricks won't stand up, they won't sit down, not flat that is, and one has grown tired of trying 
to apologise for them. A volume in favour of afforestation could be written out of the criticisms of a child on this ill-made box of bricks alone.

But you will ask, What has that to do with Women and Afforestation? It is admittedly a very small link in the chain, but still it is a link. From it we realise, the women of this country can be shown how to realise, how entirely dependent upon forestry imports of all kinds, even down to the child's wooden toy, we were at the outbreak of the war.

And we, and this is the point, we have in Great Britain and Ireland some $16,500,000$ acres of mountain and heath land much of it suitable for afforestation; in other words suitable to grow the wood from which our box of bricks could be properly made; and incidentally pitwood, wood pulp and other much needed materials. To take what may really I think be considered a minimum-there are 5,000,000 acres of land in this country which could be more profitably used for growing crops of trees than for any other purpose. How does this affect the women, the bulk of the women in this country? It affects them in this way, and this is my first point. The air at the present time is full of the thrift crusade. We are told to economise, to save, to refuse to buy or consume imports of all kinds, to do this and that. This is more or less a personal matter, a crusade in the home. It is of the first importance and we are doing our best. But as I see it there is another crusade of equal importance. And this crusade has to do with the conservation of the national resources, with a full utilisation of these national resources. 
We have in this country this large area of land lying unutilised. This is not thrift. Government Committees and Royal Commissions have sat upon this afforestation question during the last twenty-five years and nothing has come of their sittings. Urgent as the question was before the war, it is doubly urgent now. It will be a national crime if we allow these millions of acres which could grow fine woods and employ a considerable population to lie derelict any longer. What can women do?

It is said, I with my Indian experience fully believe it, that India is ruled from behind the purda. In other words, that though Indian women for the most part are not seen in the streets, have in fact no personal contact with the outer world, yet they assuredly rule that world through the men in spite of the purda.

Well, I believe that true as this is for that great land of mystery, India, it is equally true with the Western nations. We men do not seem to have been able to get Government to do much in this forestry question. We hope to do so now with the powerful help of the Development Commission. But if we enlist the women of the country on our side and if they will really work for this useful cause in the interests of national economy, in the interest of their children and grandchildren, we may feel even more confident of success.

I now turn to the importance of the afforestation question from the point of view of the labour it will employ.

Here I hold strong opinions on the value of employing women in a no inconsiderable portion of the work 
connected with the woods, both in the superior grades and the inferior or labouring classes. Before the war I should have now proceeded to deal with this aspect. As an outcome of the war, however, I have first a suggestion to make to the woman and a plea to make to her unselfishness. She will, I trust, help us to get women to take up forestry work as a work in which they can find useful and congenial employment and help us to disabuse the minds of many of the sex of their dislike to occupations connected with the soil and to show them what possibilities lie open to them in forestry work. But before dealing with this question I would ask the women to remember another reason for giving their aid to this afforestation matter. If the question is taken up in the near future as it should be, and on the scale it should be, it will afford, in some of its easier work, employment to hundreds of partially disabled soldiers and sailors who, having fought their country's battles and been maimed in doing so, can never hope to resume those occupations which they were fitted for before they went to the front.

If women will, as I hope, take up the afforestation crusade I have no doubts as to the place they will give these incapacitated men in their programme.

I will now turn to the employment of women-I hope I have not unduly exercised your patience in getting there-and to the openings which exist for women in forestry work.

It will be best perhaps to consider first the possibilities in front of the labouring classes. The employment of women in this direction is no new idea in 
Scotland. A decade or so ago women were employed in some of the Scottish nurseries, but they gradually fell out and gave up the work. Since the war commenced they have taken up the work again. During the season of IgI4-I5 complaints were made by the nurserymen that the attendances were very irregular. But in one instance at least the women were exonerated. The weather was bitterly cold and wet and the nursery was several miles-three to four-from the town in which they lived. If women are to be employed in forestry work it will of course be necessary that they should be suitably housed in the vicinity of the nursery or woods, and further-an important point in my estimation-that the hours should be so arranged that they can get home to have good meals and to perform that household work which is of such enormous importance in the welfare of the home and in the upbringing of the children. It is, I think, more than probable that the question of the employment of women in occupations connected with the soil has never been approached from the proper standpoint in this country. Conditions different from those suitable for men will have to be introduced if success is to be assured, and a question of the very first importance is, and I am sure every woman will agree, that both in housing accommodation and in the hours allowed for meals and household duties, their necessities should be studied. This is one direction in which women can greatly assist, for unless it receives adequate recognition it is difficult to perceive how much progress can be made in this question of the employment of women and girls in forestry operations. 
As regards the work itself. It may be considered under two heads : $(a)$ Work in the nursery, and $(b)$ Work in the woods.

(a) Work in the Nursery. - In this country as in many parts of the Continent the young plants required for the formation of new woods are raised in an area of ground termed a nursery. The commercial nurseryman will be known to you all. Many of these large nurserymen raise as part of their stock-in-trade young trees for sale. Some confine themselves almost entirely to this work. The larger landed proprietors of this country who maintain a part of their estates under woods usually possess a private nursery of their own in which they raise the young trees required for their operations. On the Continent numerous large commercial nurseries exist, and owing to the fact that they largely employ women and girls for their work, and that labour is usually cheaper than with us, they are able to undersell us in our home markets, or they were able to do so up to the outbreak of war. Whether the Continental plants are as good as those grown in our home nurseries or whether plants grown on the Continent and subsequently planted out in this country produce as good trees or as good timber are points upon which many experts have grave doubts. Anyway, the war has changed our outlook in many directions, and in the future we should learn to produce all we require in this respect in home nurseries and not spend money abroad which could be earned by our own people.

You will ask what is the nature of the work to be performed in a nursery maintained for the raising of 
young trees and in what respects it is suitable for women. The description of the work required will, I venture to think, provide the answer to the question of its entire suitability to women. In fact, in many ways women will be able to do some of it better than men and with more care than boys.

We will consider briefly the rearing of the young tree from the seed until it is planted out to form the plantation.

The area of the nursery is divided up into divisions which consist of seed beds and areas or breaks in which the older plants are placed until they have reached the age at which they are to be removed into the woods. These areas are managed on a rotation, one or more in their turn lying fallow for a year, or more usually having a crop such as potatoes taken off them at this period. In any year an inspection of such a nursery in the summer will show a certain number of seed beds in which the young seedling trees are being raised. The breaks will contain three- or fouryear-old trees. In the winter and early spring when the heaviest nursery work is in progress certain areas will require to be deep trenched. This work is not - beyond the powers of a robust woman, but for our purpose here we may leave aside the question as to whether it should be done by the man or woman.

During suitable weather in winter the breaks containing the four-year-old plants, as also some of the three-year-old plants, will provide a good deal of work. The plants are dug up, sorted out in sizes and done up into bundles and packed for transport to the spots at which they are to be planted out. In a commercial 
nursery this packing requires to be done with considerable care as the parcels of plants may have to travel long distances to their new destination. The sizing of the plants in itself takes time and requires some care, work which women could be depended upon to do and do well. The smaller plants will probably be placed to one side to be put back into a break to spend another year in the nursery All weakly ones and diseased plants will be collected into heaps and burnt. Their elimination is desirable on all counts.

We have now to consider the preparation of the seed beds. The areas required for sowing the seed are far smaller than the areas termed breaks. The seed bed is usually 3 feet 6 inches to 4 feet wide raised above the ground surface and has on either side a narrow alley which permits of the bed being weeded later on. The soil of the seed bed has to be carefully and finely prepared, a work which women could be easily trained to perform. The seed is sown uniformly over the surface or in drills, rolled in and a covering of earth spread over it, the thickness varying with the size of the seed. A light roller is then drawn over the bed and this part of the process is finished. But not so the attention required on the beds. Almost from the time of sowing the seed and throughout the summer the beds require constant weeding. Boys have usually been employed in the past, boys whose fingers are often all thumbs. For such work women or girls with their deft fingers are eminently more desirable. They would not only do the work better, but would bring to it a greater patience. For it is so easy to pull up the small tree seedling instead of the weed. And the careful weeding 
of the seed bed is one of the most important factors to the success of the seedlings. The seedlings remain in the seed bed for two years, so that there are two years' weeding to be done in them, and in any big nursery there may be many yards of beds, some in their second year and others in their first. Before the seed is sown, usually early in May in this part of Scotland, the work of transplanting the seedlings which are two years old will have been finished. This work is undertaken during the late winter whenever open weather favours its performance. The young plants are carefully dug up with a fork and sized, usually two sizes are sufficient, all weakly and diseased plants being burnt as useless. They are then "lined out," as it is termed, in the breaks : that is, placed in rows, the larger and stronger plants separately from the smaller ones. This involves a good deal of labour when your plants are numbered by the thousand, for it will be evident that a few yards of seed bed will produce several thousand plants. The lining out involves digging a trench with a vertical wall on one side, the placing of the young plants against this wall with their roots hanging down freely (the trench must be of the requisite depth to permit of this), filling up the trench and treading down the earth firmly so as to prevent all chance of the young plants shaking or wobbling after being subject for a few hours to a strong wind. Row upon row of these young two-yearold plants have to be lined out in this manner, and in a large nursery this work involves a good deal of labour. But it is work which is well within the capacity of women, and I believe they will do it better than the average boy or young man. The young trees, trans- 
म
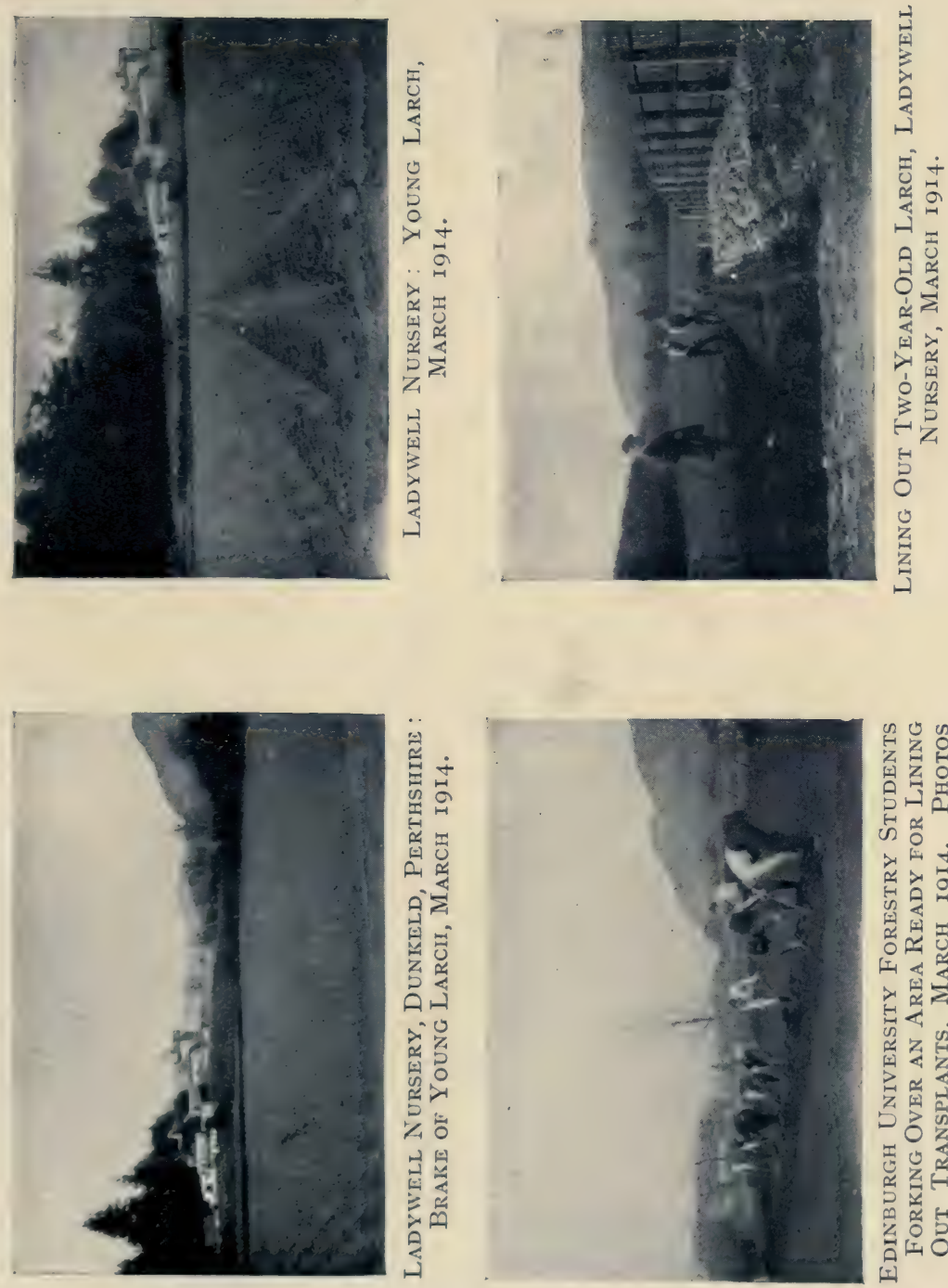

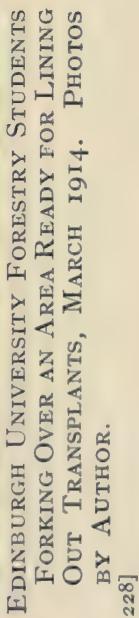



plants they are called, remain in the break for one or two years according to whether they are planted out to form woods as three- or four-year-old plants. The breaks will require hoeing between the lines during the summer to remove weeds and let in air into the soil.

I have given above briefly the main outlines of nursery work. There are numerous other jobs, as must be the case in work of this kind, which can be adequately undertaken by women. In fact, in my opinion the main portion of the staff of a nursery would better consist of women and girls than of men and boys. They will require training, but so do the men and the boys. This year will perforce see many women employed in nurseries, and whether they take a liking to the work, for an aptitude they surely possess, will depend upon whether due recognition is paid to their comfort and necessities, which must be different from those of men and boys.

(b) Work in the Woods.-At first sight it may appear that there is little place for women's work out in the woods. If we confine ourselves to the popular idea of the work of a forester, that he must be always cutting down trees-few seem to realise in this country that the trees have first to be planted, and that is probably the reason we have so many million treeless acres-if, I say, we only consider the one aspect of forestry, that of felling trees, it may be conceded that the women would not be as much in their element here. But there is not in my mind, or in the minds of any of us I trust, the idea of eliminating the mere man altogether, either from the woods or any other walk in life. Out in the woods, anyway, he will have to 
remain : for admittedly there, there exists certain work, felling, fencing, draining, and so on, which requires a muscular physique and great stamina. But there is plenty of other work in the beautiful woods which women can undertake. Those of you who have any acquaintance with the forests of Germany, France, or other Continental nations must often have met women at work in the woods. I doubt however whether you have often done so in this country, save perhaps collecting a bundle of dead sticks or picking blackberries.

But there is plenty of work for the women. To start with we will follow our young four-year-old plant to its new destination. It arrives at the area on which it is to be planted. If the work is properly done it will be planted in a hole made with a spade of some shape or other. The work of preparing the holes is usually the work of a man, because the soil on which plantations are usually made is often heavy, may be stony, and may have masses of roots in it. This is heavy labour requiring, for a long day's work, the digging of a thousand holes we will say, a man's stamina and strength. But the planting of the plants in the holes, the filling in the thousand holes made by the man, can be as well done by the woman or girl. It is not heavy work, but according as to how it is done will depend the after success or otherwise of the plantation. This is one job then that women can assist in out in the woods. The sowing of acorns in patches and lines direct in the woods can also be done by women. We will still remain with our newly planted tree. During the first year or two of its life it will have to 
struggle with a tangle of weeds of varying density. It will require help, and the giving of this help by freeing it once or twice during the growing season can equally well be done by the woman. Broom, whins, grass, young birch, bracken, etc., may all require removal in favour of the young trees on the area. A plantation of several hundred acres will provide a good deal of work. Again, disease may attack the young plants in early life. Plantations require careful inspection in this respect and the cutting out of all diseased plants, which should be burnt. Also from one cause or another some individuals in a newly formed plantation may die out in the first year or two of their life. All blanks occurring in this fashion require filling in with fresh live plants, work a woman can easily perform. Young plantations of conifers are apt to be attacked by insects. A weevil is especially bad in parts of this country. It breeds in all felling areas and from here the mature beetle spreads into newly planted areas of young trees and infests and kills them. A variety of traps are made use of to get rid of this pest. In Germany this work is usually in the hands of women and girls. The larch sawfly is another pest which women could attend to successfully. Birds, black game, animals, e.g. deer, also commit injury in plantations. Preventive measures are in force to combat them which women could attend to as well as men. Barking felled trees can be done by women. In fact it may be said at once that the employment of women in the woods would enable a good deal of work to be attended to which in the past has perforce, owing to a paucity of establishment, been 
left undone or done ill, to the detriment of the woods themselves.

I now come to the last part of my subject, one which in some respects is one of the most interesting, the training of women in the higher branches of forestry, the training of women as foresters. I have already dealt with this subject at some length in a paper in the Englishroman for December last, ${ }^{1}$ so may confine myself to briefly stating the chief aspects of the case as they appear to me.

The life of a forester is pre-eminently an open-air one. A good executive officer will spend the greater part of each month out of doors in the woods. This of itself makes the profession a fascinating one for those who prefer the open air to the desk. But at the same time it renders the possession of a good physique, good health, and active habits indispensable. Girls, the modern girl at any rate, may be considered to possess these attributes to much the same extent as young men. In addition, the would-be scientifically trained forester requires to possess a love for nature as it exists in the woods combined with powers of close observation. These latter the education of the forester endeavours to stimulate and bring into full play.

How is the executive forester, that is the man who has charge of areas of woods, trained? The education of such has been brought to a considerable state of development during the last few years, thanks to the liberal manner in which the Development Commissioners have aided in this matter. Here in Edinburgh a degree of B.Sc. in Forestry is conferred, whilst Oxford 
and Cambridge and other centres grant a diploma in the subject. It may be regarded as tolerably certain that in the future the possession of a degree or diploma in forestry will be looked upon as an essential qualification for any young woman or man aspiring to obtain an executive post in the management of woods in this country. The candidate would not of course aspire to obtain charge of an area of woods the moment the degree had been obtained. He or she would have to serve a probationership as assistant in such a charge, as is the case with any youngster entering one of the State forest services existing in afforested countries in Europe and elsewhere. But the possessor of a degree would aspire to take rank in the superior grades and not commence in the subordinate ones. The curriculum for a degree is an eminently practical one. In Edinburgh it includes courses in Botany, Zoology, Chemistry, and Natural Philosophy; and advanced courses in Forest Botany, Mycology, Forest Zoology, Forest Engineering and Surveying, Forest Chemistry and Geology, with Forestry Elementary and Advanced. Three years' work are required to obtain the Edinburgh degree. The purely forestry portion of the curriculum involves two years' work (the second and third years of the course) including practical courses of from six to seven months altogether. The practical courses are designed to give as thorough a training as time permits in the manual part of forest work, both in the nursery and in the woods. This work we have already briefly considered. The student is made to do with his own hands all these manual operations on the principle that a man cannot be fit to give orders unless 
he knows how the work should be actually performed. In Scotland we have magnificent nurseries and areas of woods available for this purpose, whose proprietors give us a cordial welcome and permission to make full use of them. In England the Forest of Dean now forms a fine Demonstration Area. The advanced practical courses teach the student how to survey areas of woods, measure up the cubic contents, how to carry out thinning operations, and finally how to prepare scientific plans for their management. Nor is the protection of the woods from the various dangers-insect and fungus and so on-forgotten.

The only portion of these practical courses that is likely to overtax the woman is heavy trenching work with the spade (though I know of instances where she can put many men on their mettle in this direction), and the use of the heavy axe and saw in felling trees. But though it is important that the executive forester of the future should know how these operations are performed she will not herself have to actually do this work. Hers will be the brain which will control and direct the operations to be carried out in the woods. Therefore it should be possible for the woman, by using lighter forms of these tools, to make herself sufficiently acquainted for all practical purposes with the correct methods of using the spade, saw, or axe during her practical courses.

Lastly as to the work of the forester. The above sketches will, I trust, have afforded some knowledge of his operations. But the life is a very diverse one. The forester is always at school, for the better he is acquainted with the varied life of the woods, veget- 
able and animal, the greater knowledge he possesses on the habits of his trees and the localities in which they grow, the better forester he will prove and the better the results he will show. He has opportunities, perhaps better than fall to the lot of most, for carrying out research work in one of several distinct branches. He may be interested in or develop a love for botany or mycology, entomology or forest engineering, with which is associated that important branch connected with the extraction of the materials from the woods in the cheapest manner. There is room for much work in this direction in this country. He may be of a mathematical turn of mind and carry out studies into the methods of calculating the yield which different soils and species can produce; or forest economics and the utilisation of the various products of the forest may claim his interest; or finally the law of the forest, its connection with the civil and criminal laws of the country, and the numerous loopholes it affords the forest offender of escaping from all penalties, may provide a fascinating and intricate study during his spare hours. All these forms of forest research exist. All are within the powers of women to assimilate. And, so far as the forests and woods of our great Empire are known to me, all of them offer opportunities to the young scientifically trained forester to make a name for her or himself. 


\section{XVI}

THE EMPLOYMENT OF WOMEN IN FORESTRY ${ }^{1}$

\section{The Manual Part of Forest Work}

THERE are few industries in which conservatism is so strong as those connected with the soil. The conservative nature and strong prejudices of the farmer, and the grave suspicion with which he regards the employment of new methods, have become a byword. What is, perhaps, not so well known is the attitude of the forester with respect to innovations. We foresters are, in many respects, very much, if not quite, as conservative as the farmer. As a general rule, the forester looks with suspicion at new methods of sowing seed in the nursery, of lining out young transplants, planting out the young trees to form woods, and so on. There is, of course, a good deal to be said in his favour. If he has won success in the past by employing his own or certain well-recognised methods, why imperil such success in the future, even if the prospect is held out of greater returns-returns which he himself cannot hope to live to see? For the forester's life and work are

1 This and the succeeding article appeared in the Englishwoman for June and December I915. They deal with the subordinate or manual and executive or supervising branches of forest work. I have deemed it best to leave them in their original form, although this involves some slight repetition of the preceding article. 
apart and distinct from most industries. He has no prospect, as a general rule, of reaping the fruit of his labours. He raises his young trees in the nursery, plants them out, and watches the first stages in the life of the resultant wood. Since the life or rotation of this wood may be anything from sixty to over a hundred years, this is the utmost he can hope to do. Succeeding generations will glean in the harvest, and praise or vilify his memory according as that harvest is good or bad.

Now, this conservatism of the forester is good in some ways and bad in others. To a great extent it keeps him from the temptation to gamble by planting on a large scale exotics of all kinds whose success in their new environment is very problematical. It also prevents him from experimenting, to any dangerous degree, with systems of forest management with which he is ill-acquainted, and which, therefore, in his hands would be foredoomed to failure. The converse of this, however, is equally true, and systems of management quite applicable to one set of conditions are kept on when these conditions have completely changed, either by differences in markets, introduction of conifers for broad-leaved trees or vice versa, increase in wages and reduction of available amount of labour, and so on.

A direction in which the conservatism of the British forester has certainly led to an increasing and, perhaps, unnecessary expense in forestry operations-and this is the point which it is proposed to deal with in this article-is to be found in the nature of the labour he employs. There is a certain amount of work connected with forestry at present performed by men and 
youths which could be equally well carried out by women and girls-in fact, some branches which could not improbably be done better by these latter.

The employment of women, in forestry operations at any rate, is not the usual practice in Britain ; in fact, it is exceptional. On the Continent, on the other hand, it is quite common. In Germany, for instance, a fair proportion of forestry work is carried out by women, and very excellently it is done and at a greatly reduced cost. In the large commercial nurseries abroad, female labour is made use of to a large extent, with the result that the wage-bill is kept down, and the plants raised can, and do, undersell in our markets those grown in this country. Doubtless, nurserymen with us would be willing to follow their Continental brethren in this respect could they obtain trained women and girls. In some cases this has been done in the past, and the war, with its resultant scarcity of male labour, has forced some to try again. In answer to inquiries instituted, the manager of a large Scottish commercial nursery writes (in I9I5) on this matter as follows:

" Up to ten years ago we employed women and girls very largely for weeding and lining out. Since trawlfishing became such a big industry up here it has been quite impossible to secure women for light nursery work, and we have had to rely more or less on lads from fifteen to eighteen years of age. This spring any amount of female labour is available, but so far we have found it not altogether satisfactory, owing to the want of regular attendance on the part of the women."

The reasons given for the want of regularity in attendance were the prevalence of bitterly cold, wet 
weather, and the distance-three to four miles-of the nursery from the town where the women lived, there being no housing accommodation in the vicinity. The women were paid I2s. per week, free insurance, with car fare home-i.e. practically I3s. per week for a week of fifty-six hours. Extra time on Saturday was paid for at $3 d$. per hour. The manager stated, as his belief, that had the weather been more genial last spring the women would have proved more regular in attendance. He stated that he would be able to employ twenty to thirty women from April to October this year (I915), and had no doubt that he would be able to train a good women staff later on. The few women who lived near the nursery and could get home to their meals proved most willing, active, and satisfactory workers.

The above report would appear to place this matter in a nutshell. Generally speaking, throughout the country it has never been approached in a spirit that would spell success. If women are to be employed satisfactorily they must be housed in the vicinity of their work, so that they can, as a rule, get home and have proper meals, and probably attend to domestic duties as well. They will, not unnaturally, require slightly different treatment to men; but their cheaper wages should make it well worth while to attend to such requirements.

But employment in the nursery is by no means the only direction in which women can be used in forestry operations. A most crying need is to cheapen the cost of the lighter work out in the woods as well as in the nursery. For with cheaper rates the former class of work will be more efficiently done than is the case 


\section{EMPLOYMENT OF WOMEN IN FORESTRY}

very often at present, because it will be possible to devote more time (i.e. labour) to it.

It is at least open to doubt whether in normal times, labour (i.e. the class of labour required) for carrying out the large planting schemes which should be put in force would be available if we adhere to the conservative practices of the past, and rule out of consideration the employment of women and girls in forestry operations. It has been stated that in some of these latter, women could do as well, if not better, than men. To make this contention clear it will be necessary to glance briefly at the various operations connected with forestry work in this country in which women could be employed. Our plantations are for the most part what is termed artificially formedi.e. the young plants are raised in a nursery, and planted out when old enough, usually three to four years, on the area on which the wood is to be formed. According to the distance apart at which the young plants are spaced, which varies with the species, elevation, etc., from 1,750 to 3,500 plants will be required to the acre. It is quite easy to reckon, therefore, that if planting operations on any large scale are to be undertaken by artificial means, millions of plants of the requisite age will be required, and will have to be raised in nurseries. Two distinct forestry operations are dealt with above-the raising of plants in the nursery, and their planting out to form woods. During the early life of the young plantations a certain amount of supervision work is necessary. A heavy growth of weeds may threaten the young plants with suppression and death during the first two or three years. The 
young trees may require protection against pests, such as insects, birds, deer, and so on ; they require to be carefully inspected for disease, such as the common larch canker. All this class of protective work comes under the category of "light" work.

The above instances of the lighter parts of forestry operations will serve to show that in certain directions there is work which could be easily performed by women; work in fact, which they could do at least equally as well as men, and on which it appears rather a waste of labour to employ the latter.

We will glance at the operations I have sketched above in greater detail.

The Forest Nursery.-In the nursery there is a certain amount of heavy work connected with trenching the ground, and so on, which requires to be done by men. This, however, only occurs at one season of the year, and forms but a fraction of the work carried on in the nursery. Once the heavy trenching is done, the upper layer of soil requires to be broken up and reduced to a fine consistency-light work which can be done by women. In the spring, seed-beds are prepared and seed sown. Seedlings, one or two-year-old, are lifted out of past years' seed-beds and transplanted, or lined out, in breaks. The trenching of these latter areas will have been previously done by men, but the work of lining out the seedlings at so many to the yard in the line, and with a prescribed distance between the rows, is work that can be done by women. Owing to the fact that the latter are, as a rule, lighter-fingered than men or youths, it is work that can be better and more quickly performed by them. As the wage-bill 
would be less, we could raise, buy, or sell our plants at cheaper rates per I,000, and they should have at least equally good roots as those transplanted by men, and in all probability would have better ones.

Transplanting and sowing work over, there comes the heavy work involved in weeding. A great part of this work is done by lads, and it would be interesting to know the proportion of seedlings pulled up with the weeds during a season's work. Admitted that one finds occasionally a clever-fingered youth; but the average in this respect could in nowise compare with the average in the other sex. Moreover, a number of the seedlings of our trees are excessively small when they first germinate and during their first year's growth. Surely if there is a work at which women and girls should excel, it should be this job-a most important one in a large nursery. There are numberless other operations in the nursery which could be equally well performed by women and girls with at least as good results.

Turning now to the woods: it may appear that here at any rate is man's work, if only for the reason that the manual labour connected with felling, converting and carting of timber, making roads, fencing work, and so on, is heavy. It may be at once admitted that this side of forest work is particularly that of the man. But there is a variety of light work in which there does not appear any adequate reason why women should not find employment. This work varies, both in nature and the season at which it has to be done. For instance, in planting out young trees: the manual work connected with the preparation of 
the holes in which the plants are to go, often heavy, in stiff or stony soil, is man's work, and can be done by a squad of men. But experienced women or girls could plant the trees in the holes thus prepared at least as well as men or lads, and perhaps would be apt to be less careless than the average man. For if the young tree is to grow and thrive, it requires to be put into its new position with some degree of care. Inattention to these requirements is responsible for at least 50 per cent. of the deaths which occur within the first year of the life of a young planted wood. Then, as has been already mentioned, there is a considerable amount of work in connection with the protection of the new-formed wood.

During the first year a dense growth of coarse grass, weeds or bracken, etc., may grow up on the area, especially on the portion immediately surrounding the plant, where the soil has been newly turned over. This will require cutting back during the summer, and the operation may have to be repeated in the following year. Broom, whins, etc., may require like treatment, as also young birch, which come into young woods by means of blown seed, and thrive with amazing persistency in this country, and require cutting back. Again, the young plants may become diseased early in life. This is particularly the case with young larch, which get cankered. Searching for such diseased trees and cutting them out is light work, and could be easily done by women.

Young plantations of conifers are liable to attack by insect pests. One insect, a weevil (Hylobius), is a particularly bad one in many parts of Europe, and in 


\section{EMPLOYMENT OF WOMEN IN FORESTRY}

our own country. It infests and kills young conifers in newly formed plantations, especially Scots pine. Traps of various kinds (it is unnecessary to detail them here) are made use of to attract and capture this insect, and these traps require to be set in position, and also to be visited at intervals, in order to collect and kill the insects attracted to them. The larch saw-fly is another pest which can be attacked with success at a certain stage in its life-history.

The depredations of birds such as black game, and animals such as deer, etc., can be circumvented by either tarring the terminal shoots or whitewashing the terminal buds of conifers ; or, as is done in Germany, by fixing a small metal clip to the terminal shoot which pricks the deer's nose when bending down to feed on it. All these, and other operations, are carried out by women and girls in Germany and elsewhere on the Continent, and the work is done cheaply.

The present would appear to be an excellent opportunity for considering whether a commencement cannot be made in this direction in this country. Forestry is an expensive business with us. To some extent we make it expensive for ourselves, and then are unable to understand why we cannot compete with the foreigner. We preserve our rabbits, which eat off year after year all the young naturally germinated seedlings, get into the plantations and destroy numbers of the young plants planted out at considerable expense, or wound them by gnawing the bark, with the result that disease gets in; and finally necessitates the tremendous expense of netting every acre planted. 
Also, we only employ men and youths in forestry work, when there is a large amount of work which could be performed at least equally as well, and some of it perhaps better, by women.

We hear a good deal and read a good deal about the registration of women for employment during and after the war. Surely one direction in which women could find employment in this country is in the lighter portion of the work connected with the industries of the soil! And one of these is forestry, a business whose importance to us and our industries in this country will be one of the factors which the war will bring into great prominence. ${ }^{1}$

Stress has been laid above on the cheaper rates at which work in the nursery and elsewhere could be undertaken by the employment of woman labour. The cheapness, however, is a relative one only. It is not suggested that the woman should necessarily be paid at a cheaper rate than the man for the individual piece of work done. Provided the work were equally well accomplished, the rate paid should be a uniform one to be earned by whoever performs the job.

So far as foresty is concerned, the disparity between the sexes is one of physique only. In forestry operations the labour supply is usually a difficulty. Thus, men have to be taken off their heavier, equally important, and more legitimate work in the woods at certain seasons to perform the lighter and cheaper forms of work in the nursery, etc., which the women could do equally well, if not better, in some cases.

1 This was written in April 1915. There can now be little doubt after twenty-two months of the war, of the importance of the forestry industry to this country. 
This article has been of a purpose confined to a consideration of that part of forestry work performed by the labourer, or woodman, as he is generally classed, although, of course, there are degrees or grades of woodmen according to experience, from the young assistant and apprentice upwards. In a succeeding article it may prove of interest to glance at the openings in the higher grades of forestry -in executive and administrative work, and so on-which it appears possible might be open to, and filled by, women. 


\section{CHAPTER XVII}

THE EMPLOYMENT OF WOMEN IN FORESTRY-continued

The Executive or Supervising Branch of Forest WORK

In the previous article consideration is given to the question of the employment of women and girls in certain branches of the manual part of forestry work in which, so far, men and boys have been solely employed in this country. It was there mentioned that it might prove of advantage to consider the problem of openings for women in the higher branches of forestry - that is, openings in the executive line.

That this question of the employment of women in work connected with the soil is already receiving attention will be apparent from an article in Country Life (May 29, I9I5), by Miss Haldane, entitled " Educating Girls for Country Life." The article in question deals chiefly with the education of girls in dairy work, poultry farming, and gardening. There is an interesting allusion to forestry, however. On this subject Miss Haldane writes :

“ I know a capital young 'forestress' who, after learning gardening, begged to be allowed to attend the forestry lectures with her father; and there are some possibilities here, though, naturally, limitations also."? 


\section{EMPLOYMENT OF WOMEN IN FORESTRY}

There appears to be no adequate reason why women who are physically strong enough for an open-air life should not take up forestry as a profession. There are one or two essentials requisite to make a good forester, in addition to physical qualifications-to wit, a love of nature and natural history, combined with powers of close observation. The forester's theoretical and practical training develop and stimulate these, but they should be there from the start to make the real forester. As a race, the Britisher, man and woman, possibly possesses these attributes to as great, and perhaps a greater, degree than any other nation. It is certain that in their absence a good forester cannot be made.

It will be asked, How is a forester made? What is his work, what are the chances of posts in this profession, and what the probability of a proportion of them being filled by women? It is the purpose of this ar icle to answer these questions, so far as is at present possible.

First, as regards the making of a forester. The education and training of the forester-that is, of the executive officer who has charge of large tracts of woods worked on commercial principles-has during the past five years developed amazingly in this country, thanks chiefly to the discerning enterprise and strong support of the Development Commissioners, who have made considerable grants of money for this purpose. Forestry courses, including both elementary and the highest branches of the subject, are now delivered throughout the country at University centres and Agricultural Colleges. The courses in the advanced 
branches are intended for the education of the highest grades of the executive forester of the future. For it is certain that in the future the man with the forestry degree or diploma will have the preference over the man who does not possess either. In fact, he is already receiving the preference. The training for the degree or diploma in forestry at the Universities (Edinburgh gives a degree of B.Sc. in forestry, Oxford and Cambridge a diploma) is very thorough, including courses in the elementary portions of the sciencesbotany, zoology, chemistry, and natural philosophy; and advanced courses in forest botany, mycology, forest zoology, forest engineering and surveying, forest chemistry and geology, with forestry elementary and advanced. Practical courses and excursions accompany the lectures.

At Edinburgh University three years' work are required to obtain the forestry degree, the purely forestry part of the curriculum involving two years' work (second and third years), including practical courses of from six to seven months altogether. These latter include a thorough training in the manual part of the work, both in the nursery and in the woods. The student is made to do with his own hands the whole of the manual portion of forestry work described in the previous article, on the principle that a man cannot be fit to give orders unless he knows how the work should be actually done. In Scotland we have magnificent nurseries and areas of woods in which the student can undertake this part of his work to perfection.

The advanced practical courses consist of the detailed measurement of the cubic contents of woods, 
their survey and description ; in carrying out thinning operations; in visits to woods scientifically managed under working plans ; in the preparation of a working plan for an area of woods-and so on.

Now, the only part of this work a woman is likely to find beyond her powers is the heavier manual labour, such as trenching with the heavy spade, the use of the heavy axe in felling trees of large girth, and so on. But there appears to be no reason why, by making use of light tools, she should not be able to render herself thoroughly acquainted with their manipulation in order to ensure an adequate future control over her staff. For the executive officer, whether in charge of an area of woods or assistant in such an area, is not required to do the manual labour. He is not there for that purpose. $\mathrm{He}$ is required to possess the brains and knowledge to run the machine.

It may be conceded, therefore, that so far as the training of the scientific forester, both upper and lower executive grades, is concerned, the woman should be able to assimilate it and be turned out as good an article as the man.

Now as to the work of the executive forester. It would be easy and pleasant to detail it at great length. It will, however, suffice for our present purpose to glance briefly at the salient points.

The forester's work is exceedingly diverse, and for that very reason the more interesting. It has been well said that the forester is always at school to the end of his life, and the true forester is well aware of the correctness of the dictum; for the more intimately a man becomes acquainted with the varied life of the 
woods-vegetable and animal life; the greater the knowledge he possesses of the different species of trees he may be raising or managing; the more information he gathers together upon variations in soil, climate, and a thousand and one other points in his localitythe better position will he be in to draw up a proper plan of working for his woods, and the greater will be the success he will attain in their working. To this end, and for this reason, the forester must necessarily remain a student all his days.

But the mere working of the woods in order to raise a successful crop of any particular species over a specified period of years, or rotation as it is called, forms but a tithe (though a most important one) of the forester's duties. The felling and removal of the matured woods entails a great deal of work. Protection, both against man, animals (including insects) and fungi, etc., necessitates incessant vigilance and care. Remedial measures have to be devised and put into force, and this work affords scope for the exercise of considerable ingenuity on the part of the staff. Trespass and the commission of illicit acts, theft, grazing of cattle and so on in the woods, are often the cause of much anxiety and harassment to the executive officer and his subordinates. These latter causes can often be greatly diminished by the exercise of tact; in fact, can be managed better in this manner than by any other at present known method. Tact to the forester, i.e. the possession of this quality, is almost an essential for success in his profession. For he, more than any one else on the country-side, is greatly dependent on maintaining good relations with and securing 
the good will of the inhabitants in the neighbourhood of his woods.

In addition, therefore, to considerable botanical and zoological knowledge, the executive officer must possess some acquaintance with the laws of his country, civil and criminal, and, when there are such, of the special forest laws. A correct appreciation of the value of geological knowledge as it relates to soils, meteorology as it affects development, etc., of species, is of course a sine qua non. Finally, the management of his office will necessitate a knowledge of book-keeping and accounts generally.

With this brief examination of some of the most important aspects of forest work enough has perhaps been said to indicate the nature of the duties of the forester, and of the peculiar charm attaching to them for the lover of the open-air life.

It will be apparent that the work above described could be undertaken by the properly trained woman.

We come now to our third point-the chances of posts for women as foresters.

This is a more difficult feature of the question to deal with than the other two because here we are treading upon new ground. But this war has brought into prominence so much new ground which will have to be ventured upon, that a few remarks upon the subject may be attempted here.

It will be necessary to eliminate from consideration at the present all Government posts in the Forest Services of India and the Colonies. There remain posts in this country.

They may be divided into two classes, higher execu- 
tive and lower executive. The first will in the future be filled by fully and scientifically trained men holding a degree or diploma in forestry from the Universities. The second will for the most part be trained at the Agricultural Colleges. In the past both these classes of posts have, speaking generally, been held for the most part by a man who has started either at the lowest rung of the ladder as a forest labourer or labourer apprentice, or as an apprentice of a higher class who has subsequently taken elementary courses in botany, zoology, and so on, or attended extension lectures in such. The good men from one or the other of these categories have ultimately risen to the position of head forester (i.e. executive officer) in charge of considerable areas of woods on large privately owned estates in this country.

Outside the Crown Forests (which do not of course belong to the State) there are no Government-managed areas of woods in England, Scotland, or Wales. In Ireland, State forestry has been commenced. But whether State-owned, State-managed, or privately managed (perhaps under State supervision in some cases), there can be little doubt that a much larger area of land will be placed under woods in the near future in these islands. The war has made this imperative. It may therefore be taken as certain that more trained foresters will be required-in fact, it might almost be said, are required at the present moment.

There is one further point. Experts for forestry research work are already needed, and in some degree will be required in the near future. This work consists 


\section{EMPLOYMENT OF WOMEN IN FORESTRY}

in studying the woods from various aspects. It may be the purely sylvicultural aspect; the zoological, so far as the study of forest pest 3 is concerned; botanical, mycology and the study of fungus pests ; the preparation of special plans for managing areas of woods; forest engineering and the export of material; or finally, forest economics and the means of utilising to the full all the varied products of the woods, especially undeveloped products.

In this matter of forest research work, not the least fascinating of the many-sided and varied branches of forestry, surely a woman could find herself at her best. That the work is of the first importance cannot be gainsaid. But to be able to prosecute it with successful results entails, first, a thorough grounding in and knowledge of forestry in all its branches, combined with the necessary study of the allied subjects, botany, zoology, chemistry, geology, and so on.

My sole excuse in writing on this subject in such detail rests in the fact that since the former article appeared in the Englishwoman I have received several letters from various parts of the country expressing interest in the subject, and a desire for further information. The above is an endeavour to place such points as suggest themselves before the public. 


\section{N D E X}

Acetone, a forestry product, 103 Afforestation in Britain, area required, $24,39,22$ I

_ - arguments against, 25

_ _ - for the, 24, 25

- - past history of, $14,4 \mathrm{r}$, 163

- problem in Britain, the, ro, 163

- - in Ireland, Io

- question and posterity, xii, xix, 29

- - apathy of public and Government on, 28

- - at outbreak of war, position of, 13

- - in Britain, recent history of, $13-22$

- - in reign of Charles II, ix, $x i, I_{3}$.

- - planting up of waste lands, 29, 38

- position of, now, 23

- schemes, financing of, 35,37 , 4 I

- yield in materials from, 39

America, supplies from, 62, 70 , 78,107

Arboricultural Society, Royal Scottish, I7

Belgium, destruction of forests in, 72

Birmingham water catchment area, planting of, $2 \mathrm{I}$

Bobbin mills, 25

Camps water catchment area, planting of, 22
Canada, supplies from, $8,62,70$, 78,107

Cedar (Cembran pine) trade of Asiatic Russia, ${ }_{54}$

Central Powers, forests of, 79, 105, 106

Colliery proprietors and pitwood supplies and prices, 24 , $57,59,178$

Corporations and afforestation, IO, I9, 30

Demonstration areas, forestry, 20, 234

Destruction done to towns, houses, etc., in fighting areas, 4, 70

Development Commission, appointment of, 19

- - forestry work of, 19

- offers of funds for planting, 30

- Commissioners and forest education, ro

Edinburgh and District water catchment area, planting of, 2 I

- University Forestry Degree, curriculum for, $54,233,249$

Education and training in forestry, 53

- of an executive forester, $24^{8-}$ 52

Evelyn's Sylva, ix, 24, I64

Exports of forestry materials in I 915,2 II-I 4

Fellings in British woods, xxi, $7,29,38,60,175$ 
Finance and planting methods, 37

Finland, the forests of, $\mathrm{rO}_{4}$

Forest materials, exhaustion of world's supply of, 108, 160

- of Dean, oak in, 42

- service, the Indian, I62

- survey of Glen Mor, 17

Forester, how to make a, 248

- life of a, 234

Forestry advisory officers, 19, 29,35

- a State business, II, 29

- branches of Departments of Agriculture, establishment of, 3 I

- commercial, 10, II, 23, 31

Forests, destruction of, in fighting areas, 3, 29, 198

- felling of, by Germans, in occupied territory, $4,72,198$

- State recognition of importance of, 161

France, forestry materials of, 56 , I06

Freight vessels, shortage of, 3 , $57,61,18 \mathrm{I}$

Furniture manufactories, 25

Germany and Russia, 7 I

- forest resources of, $\eta^{\mathrm{I}}$

Home Timber Committee, 7,38 , $5^{8}$

Imports and exports of timber in I915, 202

- British forestry, where they come from, 5, 55, 104, I66

- forestry, in $1913,41,160-173$

- of forestry materials, effect of war on, 3, 55

- of forestry materials to Britain, 2, 55, 66, I 66

Ireland, State Forestry Department in, 22

Labour for afforestation, 34, 50

Lake. Vyrnwy water catchment area, planting of, 2 I
Lanarkshire water catchment area, planting of, 22

Landowners and afforestation, IO, II, I9, 30

Land purchase by Government for afforestation, 30

Leeds water catchment area, planting of, 2 I

Liverpool water catchment area, planting of, $2 \mathrm{I}$

Manchester water catchment areas, planting of, 2 I

Markets, timber, British and European, 2, I66

- - competition in, by Allies, $4,6,8,70,105$

- - control of, 70

National planting scheme, a, I, $27,3^{8}$

- resources, utilisation and conservation of, $\mathrm{xxv}, 27$

Newfoundland, supplies from, 8 , $62,70,7^{8}$

Norway, forestry resources of, $6,8,9,78,106$

Nurseries, emergency, 34

Nursery, the forest, $24 \mathrm{I}$

- work for women in the forest, $225,238,24$ I

Paper pulp mills, 25, 218

Pitwood from abroad, 56,67

- imports in $1915,203,205$, 210

- in Britain, 6, 57, 59, 178

- supplies, effect of six months' war on, 182, 189

Planting and the State, xviii, II, 30

- at Murthly with semi-circular spade, cost of, 49

- corps, a, 34

- methods, 42-9

- relative costs of different methods, $4^{8}$

Plants, numbers of, for afforestation, 33

Prices of forestry materials, rise in, $3,23,37,3^{8}, 56,57,61,64$ 
Pulp, paper, 24, 25, 167, I69, 218

— wood, I93

- - imports in 1915, 206-II

Research work in forestry, 253, 254

Rotations for forest crops in Britain, 13, 26, 39

Royal Commissions and Committees and afforestation, I, $15,23,28$

- Society advocates planting, ix, xii, $x x, x x v$

_- of Arts and tree planting, xiii

Russia and British forestry imports, $5,8,55,60,63,67,166$

- forestry resources of, $9,67,7$ r, 73

- in Europe, forests of, 82

Russian forests and British timber supplies, 67

_ - leasing of, by Great Britain, $8 \mathrm{I}$

Saw mills, 25, 75, 218

Siberia and Turkestan, forests of, 130

Soldiers and sailors, incapacitated, employment of, in forestry, 51, 223

Species to plant, 42

State and planting, the, xviii, II, 30

Sweden, forestry resources of, 6 , $8,9,62,78$, ro6

Talla water catchment area, planting of, $2 x$

Thirlmere water catchment area, planting of, 21

Timber famine in Europe, 23, 56,160

- imports in $1915,204,206-10$

- supplies, famine prices, 55

- - effect of six months' war on, $181,183,186$
Timber, supplies of future, suggestions for safeguarding our, $27,68,77$

- uses of, in fighting areas, 3,56 , 104

Timbers, commercial classification of, 169

- in most demand, pines, spruces, firs, 4,166

Toys, making of wooden, in Britain, 218

Trenches, length of, on Western and Eastern fronts, $\mathrm{IO}_{4}$

Virgil and planting, xxiii, xxiv

War, effect of the, on the afforestation question, 23-6, 28, 173

- forestry materials, demands for, 56,104

- six months of, effect on timber supplies, $18 \mathrm{I}$

- timber materials, Government purchases of, from British woods, 38

- timber supplies and the, 160

Waste land in Britain, $1,15,24$, 27

- - afforestation of, II, 24

Water trusts and the afforestation of catchment areas, IO, I9, 30

Women, assistance of, in pressing afforestation of Britain, 216

- employment of, in manual part of forest work, 236

- forestry posts for, in executive grades, 253

- in forestry, employment of, $50,215,236,247$

- in higher branches of forestry, training of, 232, 247

Woodlands, arealof British, I 5, 24

- British, for shelter, 39

- - for sporting purposes, 39

Woods, work in, for women, $229,240,242$ 
PRTNTED BY

RAZELL, WATSON AND VINEY, LD.,

LONDON AND AYLESBURY,

ENOLAND. 


\section{TREES AND SHRUBS HARDY IN THE BRITISH ISLES}

\section{BY W. J. BEAN}

ASSISTANT CURATOR, ROYAL BOTANIC GARDENS, KEW

With over 250 Line Drawings and 64 Half-tone Illustrations. 2 Vols. 42s. net.

"Here is a book which stands out by itself as the work of a master of the subject. No one who cares for trees and shrubs can possibly do without it; for not only does it describe concisely and accurately from personal knowledge all the trees and shrubs which we know, but also a great number of recent introductions, about which we know little or nothing.

"Mr. Bean, who for many years has been in charge of the most complete and correctly named arboretum in Europe, has managed to get into the space of two octavo volumes a mass of knowledge and experience which is unrivalled, and though one does not look for literary polish in a work of reference like this, his writing is fluent, precise, and free from the vague statements that in so many horticultural works leave one in doubt as to what the author means, or whether he really knows what he is writing about. . . .

"In the short space at my command it is impossible to do justice to this book, which must remain for many years to come by far the best of its scope and price on a subject which will always be dear to every lover of Nature and gardens."-Mr. H. J. Elwes, in Country Life. 


\section{By A. D. HALL, M.A., F.R.S.}

FORMERLY DIRECTOR OF THE ROTHAMSTED EXPERIMENTAL STATION

\section{AGRICULTURE AFTER THE WAR,}

3s. 6 d. net.

"Small in size, but great in value, the work deserves wide circulation and careful consideration."-The Times.

\section{THE SOIL: An Introduction to the Scientific} Study of the Growth of Crops. Second Edition, Revised and Enlarged. 16 Illustrations. 5s, net.

"This is a remarkably well-arranged and well-written volume. In its way it is a masterpiece, and it leaves on the mind an impression of great and reasonable hope."-The Times.

\section{FERTILISERS AND MANURES. 9 Illus- trations. 5s, net.}

" He is able to give innumerable practical notes on the results of experiments in manuring. It is these practical notes which we think will form the chief attraction to the cultivator, as the results of actual work on the land do not always coincide with theories based on laboratory work alone; and those who, like the author, are able to collate the two, and show just how and why certain manures give good or bad results, according as they are applied to light or heavy soils or other varying conditions, are doing a great work for agriculture, and through it, to horticulture also."- Horticultural Advertiser.

\section{THE FEEDING OF CROPS AND STOCK:}

An Introduction to the Science of the Nutrition of Plants and Animals. 24 Illustrations. 5s. net.

"The products of Mr. Hall's knowledge and experience are always welcome in the manuals which come from his facile pen, but that now under notice is especially so, as it is complementary to his works on soils and manures which have previously appeared."-Agricultural Economist.

\section{A PILGRIMAGE OF BRITISH FARM- ING. 5s, net.}

"Marvellousiy accurate and illuminating account of agriculture.... It must be for some time one of the most valuable books in the library of English agricultural literature."-HOME CounTIEs in the Daily Chronicle. 


\section{FROM MR. MURRAY'S LIST}

CREATURES OF THE NIGHT. A Book of Wild Life in Western Britain. By A. W. REes. With Illustrations. Large crown 8vo. 6s. net.

"No one with a love of wild creatures can resist the charm of such a work, every page of which shows knowledge, insight, and sympathy ... a fascinating work."-Daily Telegraph.

\section{IANTO THE FISHERMAN. By. A. W. ReEs.}

With Illustrations. Large crown 8vo. Ios. 6d. net.

"A very excellent and fascinating work, which no"lover of nature should fail to read."-County Gentleman.

A COTSWOLD VILLAGE; or, Country Life and Pursuits in Gloucestershire. By J. ARTHUR GibBs. With Portrait and many Illustrations. Large crown 8 vo. 2s. 6d, net.

\section{TENNIS: As I Play It. By Maurice E.} MCLOUghlin. With a Preface by RICHARD NORRIS Williams, Second National Champion of the United States, 1914. With 72 Illustrations from Photographs. Medium 8vo. ros. 6d. net.

"There is the breath of McLoughlin's form right through the book. . . You can see McLoughlin at work on the centre court at Wimbledon in every telling phrase. . . McLoughlin leaves no side of the game unexplained. The explanations are not done in the dry-as-dust methods, common to textbooks on games. We follow his conclusions, and race along with him to Wimbledon-the lion of the summer. ... Many champions and experts have written on lawn tennis. 'Tennis as I Play It' eclipses everything that has been before.... This work is another triumph for Maurice McLoughlin. He set out to teli us how he plays tennis. And he just keeps his word."

Moming Post.

\section{THE GENTLE ART. Some Sketches and} Studies. By Henry Lamond, Secretary of the Loch Lomond Angling Improvement Association. With Illustrations. Large crown 8vo, 6s, net.

\section{LETTERS TO A SALMON-FISHER'S SONS.}

By A. H. Chaytor. With 8 full-page Illustrations and Diagrams. Demy 8vo. 9s. net.

"No keen angler would grudge finding space for such an engrossing volume. ... Mr. Chaytor treats of all forms of salmon-fishing, with flies, minnows, worms; he describes the habits of the fish, and of their chief enemies, human and others. ... Even the expert may find much instructive matter in this most readable volume,"-Outlook. 
AFRICAN GAME TRAILS. An Account of the African Wanderings of an American Hunter-Naturalist. By THEODORE ROOSEVELT. With numerous Illustrations. Third Impression. Medium 8vo. I8s. net.

"Undoubtedly the most important sporting and travel book of the year." A rmy and Navy Gasotle.

\section{THROUGH THE BRAZILIAN WILDER-}

NESS. By THEODORE ROOSEvelt. With Illustrations from Photographs by Kermit Roosevelt and other Members of the Expedition. Medium 8vo. 18s. net.

\section{THE LION HUNTER OF SOUTH AFRICA.}

Five Years' Adventure in the Far Interior of South Africa.

By Roualeyn Gordon Cumming. With 16 Woodcuts. Large crown 8vo. 2s. 6d. net. Also is. net.

"It is many years since I first read Gordon Cumming's 'Lion Hunter 'the Lion Hunter of South Africa, as he was called. With much of the old delight I have been reading Mr. Murray's new edition of this entertaining work. . . Language fails to communicate the thrill it excites." $-W e s f$. minster Gasetle.

WILD GAME IN ZAMBEZIA. By R. C. F. Maugham, Author of "Zambezia" and "Portuguese East Africa." With Map and Illustrations. Demy 8vo. I2s. net

PARTRIDGE-DRIVING. Some Practical Hints on Increasing and Preserving a Stock of Birds and on bringing them over the Guns, with a Description of the "Euston" System. By Charles E. A. Alington. New and thoroughly Revised Edition. With Diagrams. Crown 8vo. 5s. net.

"One of the most complete and convincing of treatises on the fascinating subject of Partridge-driving that we have yet met with. Very few men, keen on providing and shooting a few head of partridges, can afford to miss Mr. Alington's clearly written account of his own experiences."-Cownty Gentleman.

FISHING AND SHOOTING. By SydNEY BUXTON, M.P. With Illustrations by ARCHIBALD THORBURN. Second Edition. Demy 8vo. 1os.6d, net.

THE WILD SPORTS AND NATURAL HISTORY OF THE HIGHLANDS. BY CHARLES ST. JOHN. With Illustrations. Large crown 8vo, 2s. 6d, net.

JOHN MURRAY, ALBEMARLE ST., LONDON, W. 


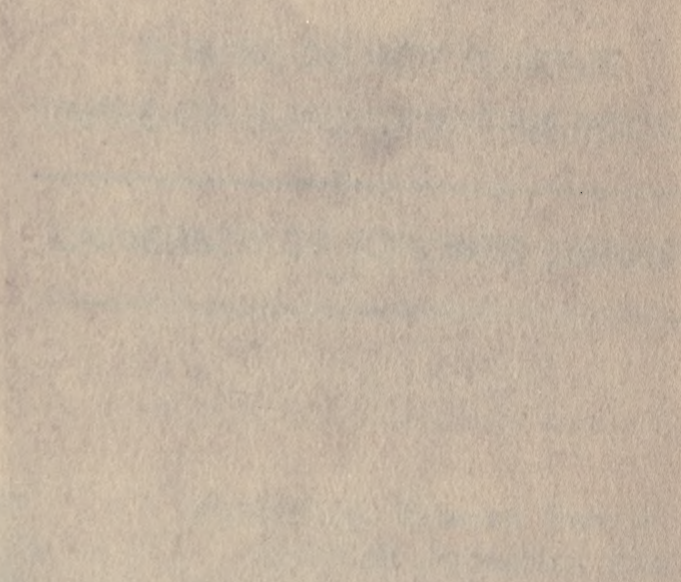




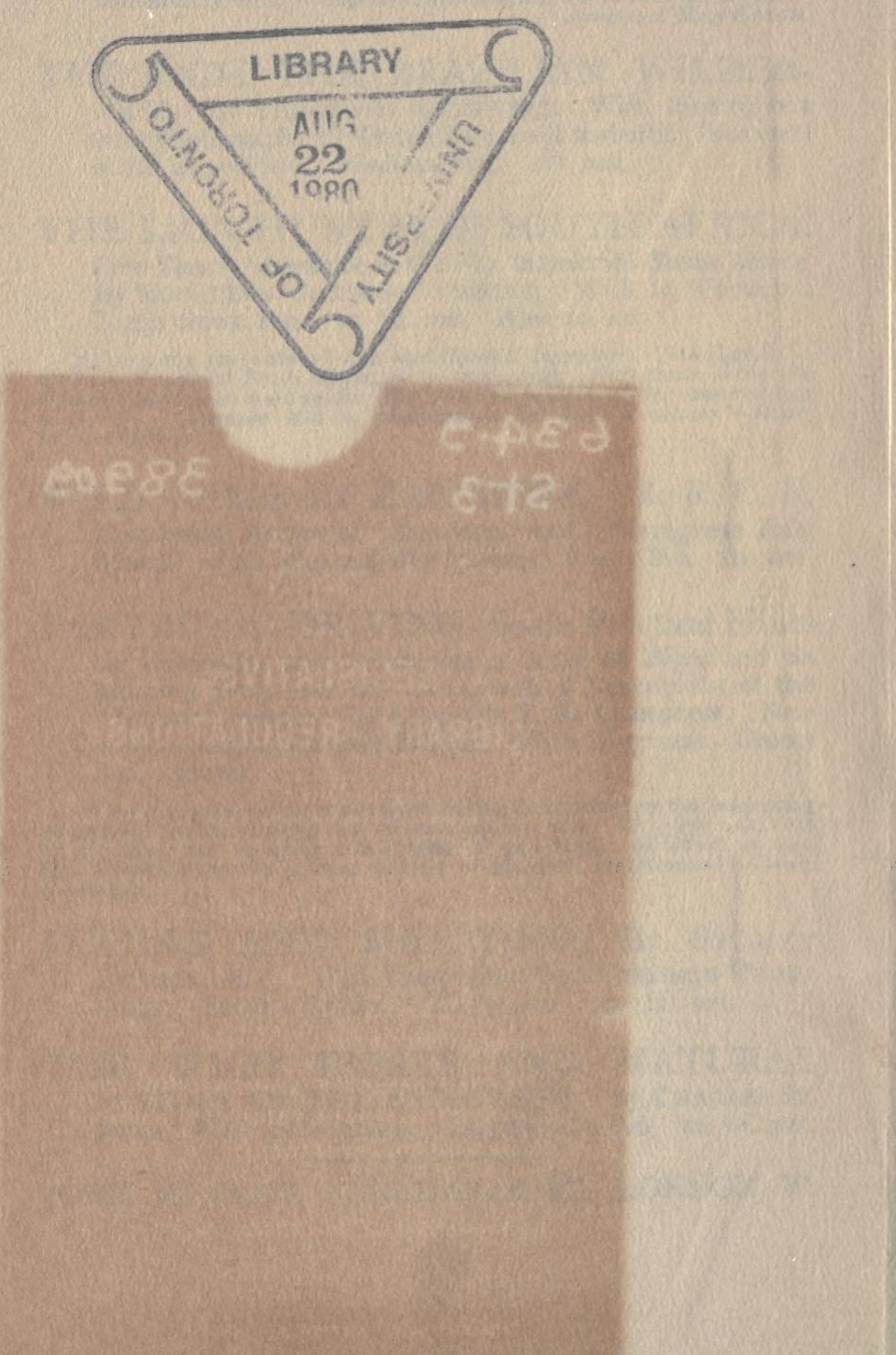




\section{PLEASE DO NOT REMOVE CARDS OR SLIPS FROM THIS POCKET}

\section{UNIVERSITY OF TORONTO LIBRARY}

SD

179

s8

cop. 2
Stebbing, Edward Percy British forestry its present position and outlook after the war

BioMed 
